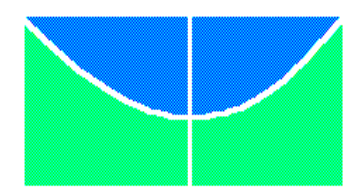

UNIVERSIDADE DE BRASÍLIA- UNB

INSTITUTO DE LETRAS-IL

DEPARTAMENTO DE LÍNGUAS ESTRANGEIRAS E TRADUÇÃO - LET

PROGRAMA DE PÓS -GRADUAÇÃO EM LINGUÍSTICA APLICADA- PPGLA

Análise de abordagem de material didático para o ensino de línguas (PLE/PL2)

VERÓNICA ANDREA GONZÁLEZ

DISSERTAÇÃO DE MESTRADO EM LINGUÍSTICA APLICADA

BRASÍLIA- DF

2 de Fevereiro de 2015 


\section{REFERÊNCIA BIBLIOGRÁFICA E CATALOGAÇÃO}

GONZALEZ, Verónica Andrea. Análise de abordagem de material didático para o ensino de línguas (PLE/PL2). Brasília. Departamento de Línguas Estrangeiras e Tradução, Universidade de Brasília, 2015, Dissertação de mestrado.

Documento formal, autorizando reprodução desta dissertação de mestrado para empréstimo ou comercialização, exclusivamente para fins acadêmicos, foi passado pelo autor à Universidade de Brasília e acha-se arquivado na Secretaria do Programa. O autor reserva para si os outros direitos autorais, de publicação. Nenhuma parte desta dissertação de mestrado pode ser reproduzida sem a autorização por escrito do autor.Citações são estimuladas, desde que citada a fonte.

\section{FICHA CATALOGRÁFICA}

\section{GONZALEZ, Verónica Andrea.}

Análise de abordagem de material didático para o ensino de línguas (PLE/PL2). / Verónica Andrea González - Brasília, 2015.

$170 \mathrm{p}$

Dissertação de Mestrado - Departamento de Línguas Estrangeiras e Tradução da Universidade de Brasília.

Orientador: Prof. Dr. José Carlos Paes de Almeida Filho.

1. Abordagem 2. Material didático 3. Ensino e aprendizagem de línguas 4.

Formação de professores

$\mathrm{UnB} / \mathrm{BC}$ 
Análise de abordagem de material didático para o ensino de línguas (PLE/PL2)

Dissertação apresentada ao Departamento de Línguas Estrangeiras e Tradução da Universidade de Brasília, como requisito parcial à obtenção do título de Mestre em Linguística Aplicada.

Área de concentração: Ensino e Aprendizagem de Língua Estrangeira.

Orientador: Prof. Dr. José Carlos Paes de Almeida Filho 


\title{
Análise de abordagem de material didático para o ensino de línguas (PLE/PL2)
}

\author{
Dissertação de Mestrado submetida ao \\ Programa de Pós-Graduação em \\ Linguística Aplicada, como parte dos \\ requisitos necessários à obtenção do grau \\ de mestre em Linguística Aplicada.
}

APROVADA POR:

Prof. Dr. José Carlos Paes de Almeida Filho, Universidade de Brasília.

ORIENTADOR

Prof. Dr. Augusto Moura Filho

EXAMINADOR INTERNO

Prof. Nelson Viana

EXAMINADOR EXTERNO

BRASÍLIA- DF

Fevereiro de 2015 


\section{AGRADECIMENTOS}

À minha primeira professora de português Gina Noivo Steffani, agradeço por me incentivar a iniciar a licenciatura de português para estrangeiros em Mendoza, Argentina.

No meu caminhar, Myriam e Roberto, meus pais, Noemí e Patrícia, minhas tias, Analía, Débora, Tatiana, Emília, Belén, Mary, Gabriela e Claudia, minhas irmãs, Aldo, meu tio, e Alejandro, meu irmão, ainda que numa distância de mais de 5 mil quilômetros, acompanharam o andamento deste trabalho. A todos eles agradeço imensamente essa companhia.

Sou muito grata à Secretária Acadêmica da Fundação Brasília (FB), Cristina García, por seu apoio incondicional e sua amizade na difícil jornada de concluir a licenciatura de português e pela acolhida em Mendoza. Da mesma maneira, agradeço a todos os professores que fizeram a diferença na minha formação docente e sempre acreditaram em mim e me apoiaram: Prof. Alfredo (FB), Prof. Clara (UNCuyo), Prof. Alícia (FB), Prof. Ivana (UNCuyo) e Prof. Augusto (UnB).

Aos meus amigos e colegas Fidel e Francisco, agradeço cada uma das conversas acadêmicas, trocas de artigos, trabalhos conjuntos, leituras (e descontrações também) que me ajudaram a dar vários passos durante todo o curso de mestrado.

Sou grata à Júlia por me fazer acreditar que no Brasil havia um lugar para mim.

A Kadu, Camila e Lea agradeço pelo amor traduzido em apoio incondicional e compreensão durante a etapa de finalização do mestrado.

A todos os alunos de várias nacionalidades e pessoas presentes na minha estada na Argentina e no Brasil que com suas dúvidas, críticas e questionamentos me permitiram refletir e melhorar minha formação no andar contínuo.

À Casa do Brasil em Buenos Aires agradeço pela gentileza de doar parte do material didático usado para este trabalho de pesquisa.

À CAPES, agradeço pelo suporte financeiro concedido durante o curso

Por último, a José Carlos, meu orientador, meu grande referente na área de PLE e na LA, sou imensamente grata pela oportunidade de realizar este trabalho de pesquisa, pelo exemplo de modéstia, conhecimento, ética e sabedoria e pelo apoio e confiança nos momentos chaves de conclusão deste trabalho. 


\section{RESUMO}

A pesquisa aqui relatada avalia dois materiais didáticos de PLE produzidos na Argentina por meio da análise de abordagem e apresenta esse procedimento como um caminho válido para auxiliar professores na seleção/avaliação/adoção de materiais didáticos prévia ao uso para o ensino e aprendizagem de línguas. Para tanto, a fundamentação teórica é da área da Aquisição e Ensino de Línguas, filiada à Linguística Aplicada. Do ponto de vista metodológico, trata-se de uma pesquisa qualitativainterpretativa, mais especificamente, um estudo de caso na modalidade de análise documental. A principal fonte de dados foram documentos, ou seja, os livros didáticos de PLE argentinos. Os registros foram coletados usando questões e categorias por meio do próprio procedimento de análise documental e interpretados com o suporte do arcabouço teórico. As questões e categorias de análise cobrem os seguintes temas: os traços característicos de abordagem das unidades, atividades e insumo nos materiais, a abordagem dos autores, os papéis implícitos de alunos e professores nos dois livros didáticos e os conceitos implícitos de língua, linguagem, língua estrangeira e aprender e ensinar uma língua estrangeira. Todo o trabalho de pesquisa foi guiado pelo construto de abordagem de Almeida Filho (1997) na Operação Global de Ensino de Línguas e as duas macroabordagens gramatical e comunicativa. Os resultados obtidos podem vir a constituir o esboço de um guia para auxiliar professores na seleção/avaliação/adoção de materiais didáticos prévia ao uso para o ensino e aprendizagem de línguas baseado no procedimento de análise de abordagem.

Palavras-chave: Análise de Abordagem. Material Didático. PLE. Macroabordagens Gramatical e Comunicativa. 


\begin{abstract}
This research contains the analysis of the approach of two teaching PFL (Portuguese as a Foreign Language) materials produced in Argentina and presents the analysis of approach procedure as a valid way to assist teachers in the selection / evaluation / adoption of teaching materials previously using them for teaching and learning foreign languages. Therefore, the theoretical framework is based on the area of the Language Teaching and Acquisition, which is affiliated to Applied Linguistics. From a methodological point of view, it is a qualitative-interpretational research, more specifically, a case study in the form of document analysis. The main source of data was the documents, i.e., PFL Argentinean textbooks. The registers were collected using questions and categories from the document analysis procedure itself and interpreted with the support of the theoretical framework. Questions and categories cover the following topics: the characteristic features of the approach of the units, activities and input in the materials, the authors approach, the implied roles of students and teachers in both textbooks and implicit concepts of language, foreign language and foreign language learning and teaching. All the research work was based on Almeida Filho's approach concept (1997) in the Global Operating Language Teaching and both grammatical and communicative macro approaches too. The results are likely to be the outline of a guide to assist teachers in the selection / evaluation / adoption of instructional materials previous their use for teaching and learning languages based on the analysis of approach procedure.
\end{abstract}

Keywords: Approach Analysis. Teaching materiales. PLE. Grammatical and communicative macro approaches. 


\section{RESUMEN}

Esta investigación evalúa dos materiales didácticos de PLE producidos en Argentina por medio del análisis de enfoque y presenta ese procedimiento como un camino válido para auxiliar profesores en la selección/evaluación/adopción de materiales didácticos previa al uso para la enseñanza y el aprendizaje de lenguas. Por lo tanto, la fundamentación teórica se basa en el área de Adquisición y Enseñanza de Lenguas, filiada a la Linguiística Aplicada. Del punto de vista metodológico, se trata de una investigación cualitativa-interpretativa, más específicamente, un estudio de caso en la modalidad de análisis documental. La principal fuente de datos fueron documentos, o sea, los libros didácticos de PLE argentinos. Los registros fueron colectados usando preguntas y categorías por medio del propio procedimiento de análisis documental e interpretados con el soporte del marco teórico. Las preguntas y categorías de análisis abarcan los siguientes temas: los trazos característicos del enfoque de las unidades, actividades e insumo en los materiales, el enfoque de los autores, los papeles implícitos de alumnos y profesores en los dos libros didácticos y los conceptos implícitos de lengua, lenguaje, lengua extranjera y aprender y enseñar una lengua extranjera. Todo el trabajo de investigación fue guiado por el constructo de enfoque de Almeida Filho (1997) en la Operación Global de Enseñanza de Lenguas y los dos macro enfoques gramatical y comunicativo. Los resultados obtenidos pueden constituir un borrador consistente para de una guía para auxiliar profesores en la selección/evaluación/adopción de materiales didácticos previa al uso para la enseñanza y aprendizaje de lenguas extranjeras basada en el procedimiento de análisis de enfoque.

Palabras clave: Análisis de Enfoque. Materiales didácticos. PLE. Macro enfoques gramatical y comunicativo. 


\section{Lista de Figuras}

Figura 1 - Modelo Ampliado da Operação Global de ensino de Línguas ...................................... 31

Figura 2 - Facetas da materialidade "Material didático" ............................................................ 35

Figura 3 - Capa do Livro: Um português bem brasileiro - Ed. FUNCEB - Volume 3 ............... 47

Figura 4 - Capa dos livros "Português Dinâmico" Volume 1 e 2 - Curso de Português para

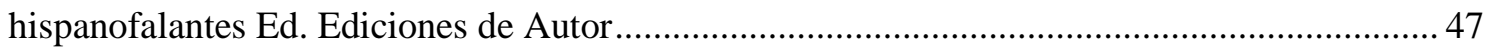

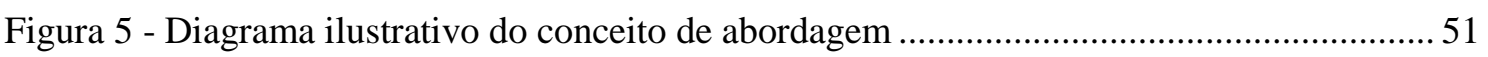

Figura 6 - Incidência de Forças potenciais no processo de ensino-aprendizagem de línguas

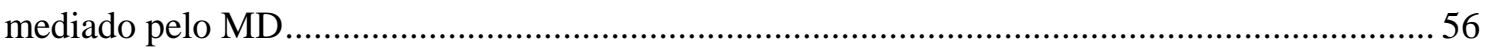

Figura 7 - Esquema processual básico de organização das unidades no planejamento

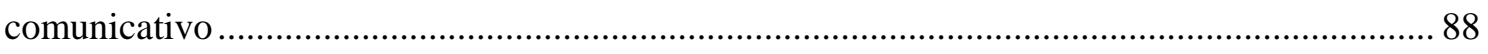

Figura 8- Atividade pré-comunicativa: produção de gênero textual (Lista) …............................ 96

Figura 9 - Atividade Comunicativa - Desempenho de papéis (Debate) ……................................. 97

Figura 10 - Exemplo de Atividade Pré-comunicativa "Interpretação de texto + Opinião" .......... 99

Figura 11 - Exemplo de Atividade Pré-comunicativa "Questionários de Opinião" .................... 99

Figura 12 - Exemplo de Atividade Pré-comunicativa "Interpretação de texto/áudio/vídeo" .... 100

Figura 13 - Exemplo de Atividade Pré-comunicativa "Busca e reprodução de informação" ... 100

Figura 14 - Exemplo de Atividade Pré-comunicativa "Desempenho de papéis" ....................... 101

Figura 15 - Exemplo de Atividade Pré-comunicativa "Troca de informação"........................... 102

Figura 16 - Exemplo de Atividade Comunicativa "Produção de Gênero Textual" ..................... 104

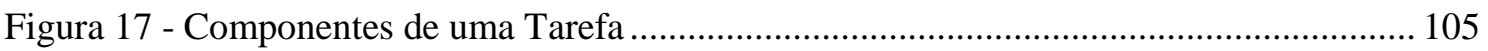

Figura 18 - Exemplo de Atividade Comunicativa "Tarefa "(Interação social: desempenho de

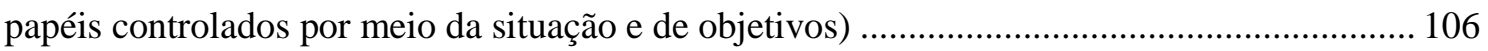

Figura 19 - Exemplo de Atividade Comunicativa "Jogos" (Adivinhação) ................................ 107

Figura 20 - Exemplo de Atividade Pré-Comunicativa "Desempenho de papéis" ...................... 114

Figura 21 - Exemplo de Atividade Comunicativa "Produção escrita de diversos gêneros textuais"

Figura 22 - Exemplo de Atividade Comunicativa "Tarefa de Interação social: lacuna de opinião" 
Figura 23- Exemplo de Atividade Comunicativa "Tarefa de Interação social: desempenho de papéis (debate) controlado por meio da situação e dos objetivos"

Figura 24 - Exemplo de Atividade Comunicativa "Tarefa cognitiva: resolução de problemas"

Figura 25 - Insumo com atividade de prática do código linguístico

Figura 26 - Atividades de prática do código linguístico

Figura 27 - Preenchimento de lacunas

Figura 28 - Produção direcionada ao uso de determinados conteúdos

Figura 29 - Relacionar Colunas/fotos.

Figura 30 - Substituição

Figura 31 - Seleção de informação

Figura 32 - Classificação de informação

Figura 33 - Verdadeiro ou Falso

Figura 34 - Texto jornalístico 161

Figura 35 - Motivos para estudar português e estratégias de leitura 162

Figura 36 - Lista de vocabulário

Figura 37 - Gramática: conjugação do presente do indicativo

Figura 38 - Leitura Complementar. 164

Figura 39 - Sugestões de leituras, filmes, documentários, sites ... 164

Figura 40 - Informação complementar. 165 


\section{Lista de Gráficos}

Gráfico 1- Princípios organizadores das unidades 91

Gráfico 2 - Natureza das atividades 97

Gráfico 3 - Classificação das Atividades Pré-comunicativas. 98

Gráfico 4- Tipo de atividades comunicativas de "Brasil Intercultural" 103

Gráfico 5- Atividades de Prática do Código Linguístico 107

Gráfico 6- Tipo de atividades do LD "Horizontes".

Gráfico 7- Tipo de Atividades Pré-comunicativas de "Horizontes" 113

Gráfico 8 - Tipologia de Atividades Comunicativas 115

Gráfico 9- Atividades de prática do código linguístico. 120 


\section{Lista de Quadros}

Quadro 1 - Resumo de indicadores de um MD com questões e categorias para análise de abordagem

Quadro 2 - Princípios organizadores das unidades de um MD 90

Quadro 3 - Princípios de configuração de atividades..... 92

Quadro 4- Taxonomia para identificação do tipo de atividades de um MD. .95

Quadro 5 - Traços característicos de abordagem do LD Brasil Intercultural 123

Quadro 6 - Resumo dos conceitos de língua, linguagem, aprender e ensinar uma LE de BI.... 124 Quadro 7 - Papéis e atitudes do professor e do aprendiz implícitos no MD "Brasil Intercultural"

Quadro 8 - Traços característicos de abordagem do LD Horizontes. 128

Quadro 9 - Resumo dos conceitos de língua, linguagem, aprender e ensinar uma LE de Horizontes 129

Quadro 10 - Papéis e atitudes do professor e do aprendiz implícitos no MD "Horizontes" 130 


\section{Lista de Tabelas}

Tabela 1 - Material Didático x Livro Didático. 30

Tabela 2- LDs para o ensino de Português LE / L2 produzidos no Brasil e em outros.. 41

Tabela 3 - Livros didáticos de PLE de produção argentina 46

Tabela 4 - Quadro resumo do modelo triádico de Almeida Filho relacionando abordagem, método e técnica.

Tabela 5 - Indicadores (categorias para reconhecimentos) da abordagem de um material didático de LE. 54

Tabela 6 - Características dos Indicadores de um MD da abordagem gramatical 61

Tabela 7 - Indicadores de um MD da Abordagem Comunicativa 66

Tabela 8 - Documentos da pesquisa .72 


\section{Lista de abreviaturas}

\begin{tabular}{|l|l|}
\hline AC & Abordagem Comunicativa \\
\hline ACIN & Abordagem Comunicativa Intercultural \\
\hline AELin & Aquisição e Ensino de Línguas \\
\hline AG & Abordagem Gramatical \\
\hline AGC & Abordagem Gramatical Comunicativizada \\
\hline BI & Brasil Intercultural \\
\hline MD & Material Didático \\
\hline MDs & Materiais Didáticos \\
\hline LD & Livro didático \\
\hline LDs & Livros Didáticos \\
\hline LA & Linguística Aplicada \\
\hline LE & Língua Estrangeira \\
\hline OGEL & Operação Global de Ensino de Línguas \\
\hline PLE & Português Língua Estrangeira \\
\hline PL2 & Português Segunda Língua \\
\hline SIPLE & Liedade Internacional de Português \\
\hline & \\
\hline
\end{tabular}




\section{SUMÁRIO}

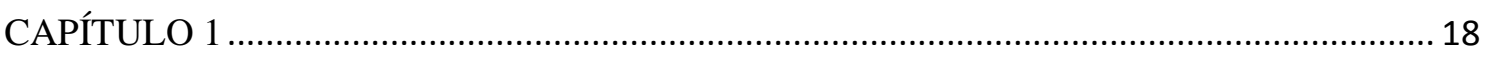

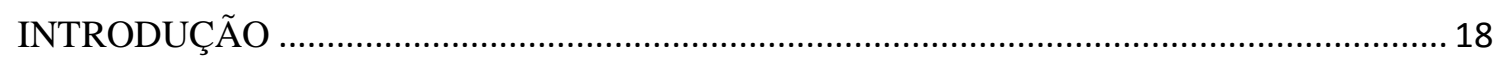

1 Tópico de pesquisa, Objetivo geral e Justificativa ........................................................... 18

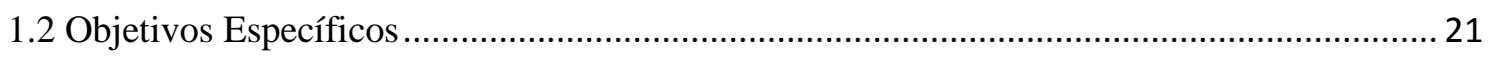

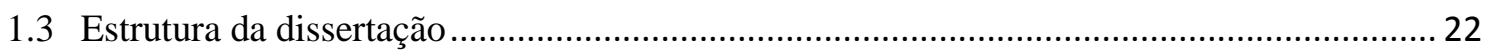

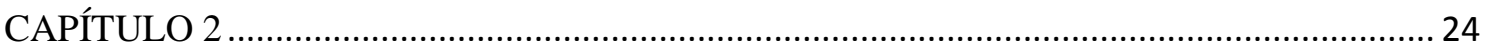

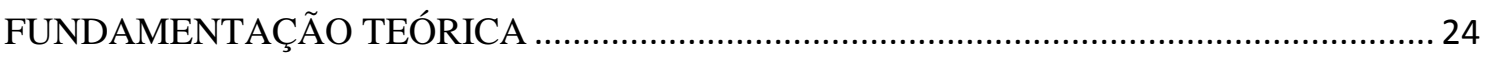

2.1 BREVE HISTÓRICO DO ENSINO DE PLE NA ARGENTINA …................................. 24

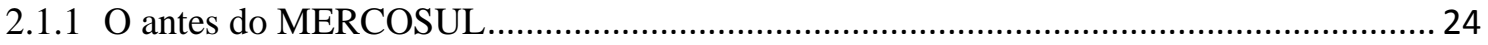

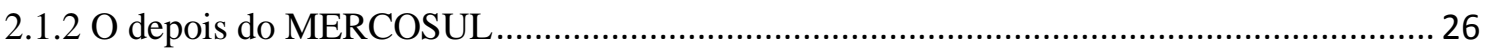

2.2 A ONIPRESENÇA DO MATERIAL DIDÁTICO NA OGEL .......................................... 28

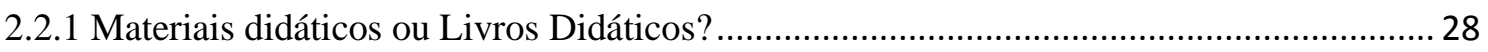

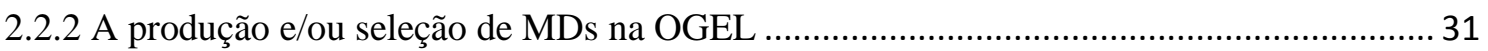

2.2.3 As facetas da materialidade "Material Didático" na OGEL: processos de criação e adoção

.33

2.2.4 Os MDs de PLE produzidos no Brasil e em outros países- Breve histórico ...................... 40

2.2.5 Os LDs de PLE elaborados na Argentina para hispanofalantes ........................................ 43

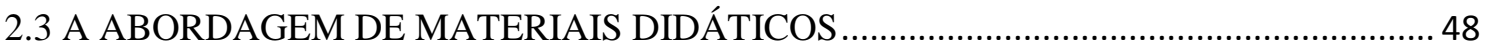

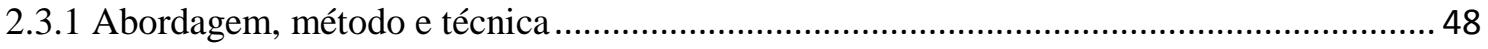

2.3.2 A constituição e análise da Abordagem ........................................................................ 53

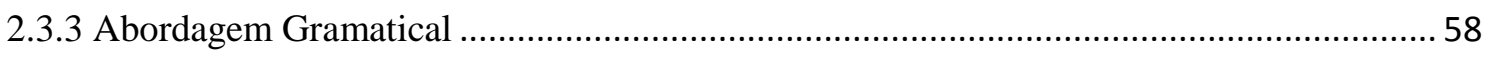

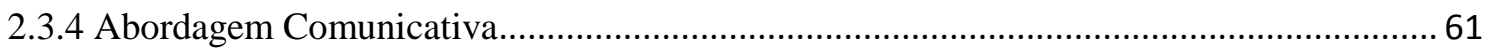

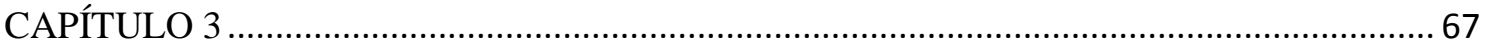

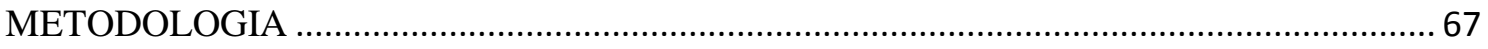

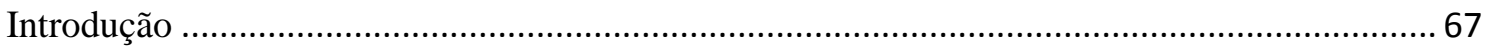




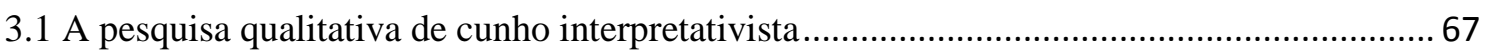

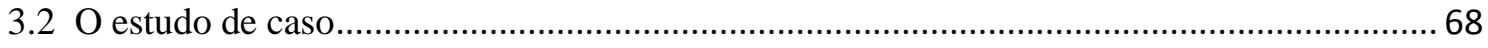

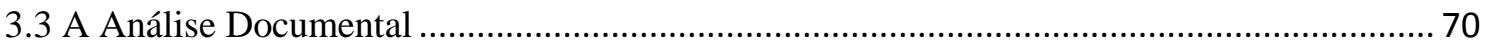

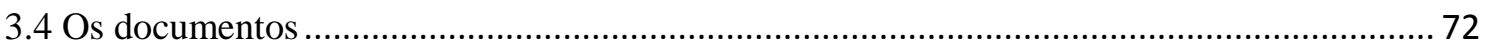

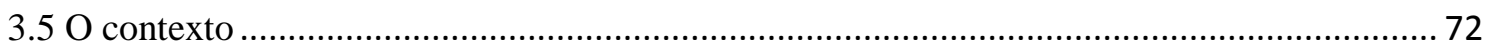

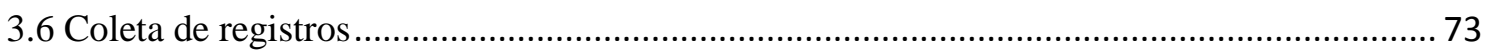

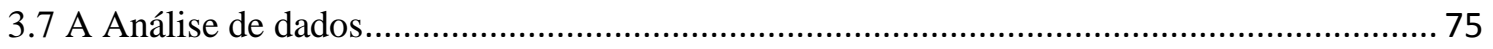

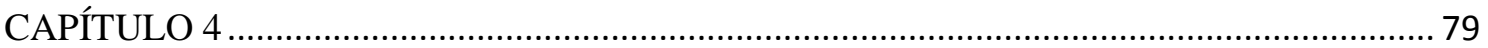

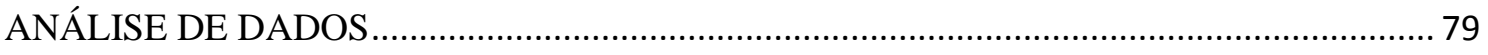

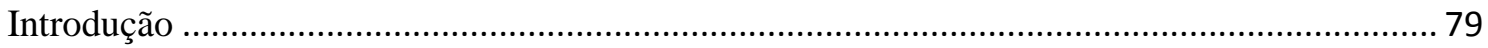

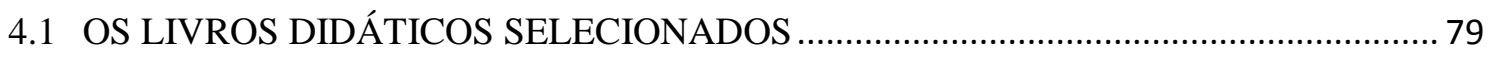

4.1.1 Brasil Intercultural: língua e cultura brasileira para estrangeiros .................................... 79

4.1.2 HORIZONTES: Rumo à Proficiência em língua portuguesa ......................................... 81

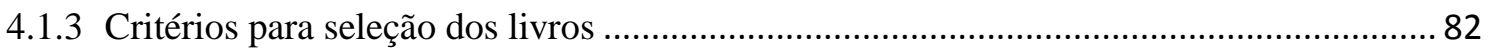

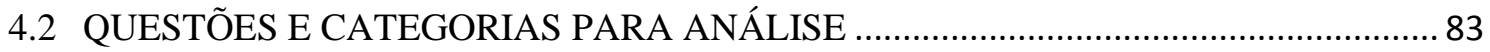

4.3 ANÁLISE DOS MATERIAS DIDÁTICOS SELECIONADOS ….................................. 87

4.3.1 Análise de Brasil Intercultural - Ciclo Básico: livro do aluno ........................................ 87

4.3.2 Análise de Horizontes: Rumo à Proficiência em língua Portuguesa ................................. 110

4.4.2 Conclusões sobre a Abordagem predominante dos MDs ............................................. 121

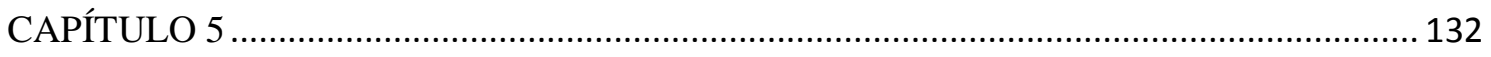

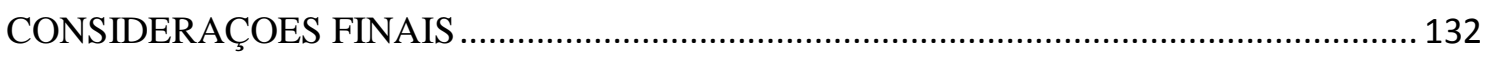

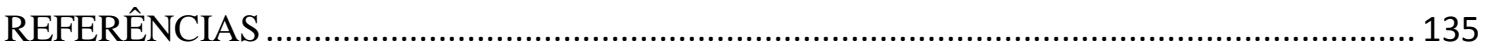

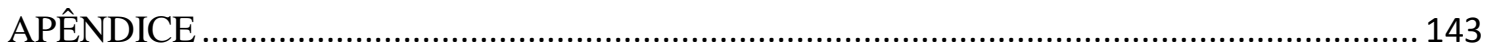

Apêndice 1 - Instituições de Ensino Superior com "profesorados" de PLE na Argentina por

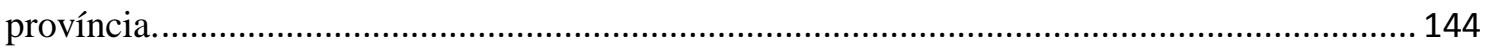

Apêndice 2 - Linha do tempo sobre alguns acontecimentos que marcaram o ensino de PLE na

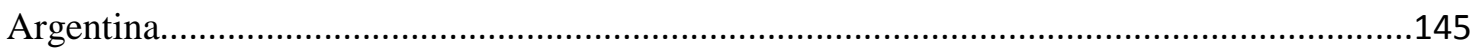

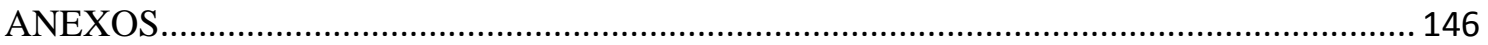


Anexo 2 - Roteiro para selecionar livros e outros materiais didáticos

Anexo 3 - "Propuesta de Ficha de análisis de manuales " ..................................................... 150

Anexo 3a - "Propuesta de Ficha de análisis de manuales " ..................................................... 151

Anexo 3b - "Propuesta de Ficha de análisis de materiales " ................................................... 152

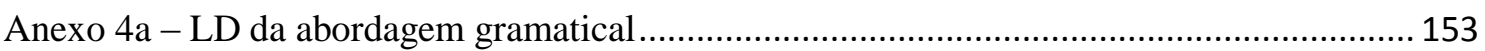

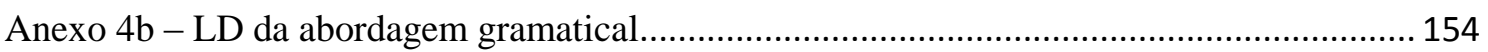

Anexo 5 - Transcrição da tipologia de tarefas de Barbirato (1999)......................................... 155

Anexo 6 - Exemplos de Atividades de Prática do Código Linguístico ....................................... 157

Anexo 6a - Exemplos de Atividades de Prática do Código Linguístico...................................... 158

Anexo 6b - Exemplos de Atividades de Prática do Código Linguístico ..................................... 159

Anexo 6c - Exemplos de Atividades de Prática do Código Linguístico...................................... 160

Anexo 7 - Exemplos de Insumo do LD "Brasil Intercultural - Ciclo Básico”........................... 161

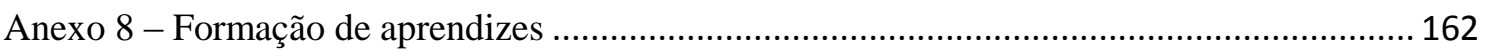

Anexo 8b - A abordagem gramatical em Brasil Intercultural................................................ 163

Anexo 9 - Exemplos de Atividades Comunicativas "Leituras extensivas" e informação

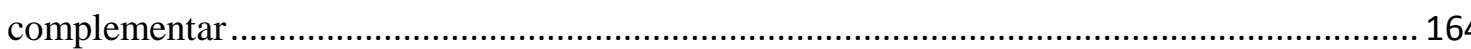

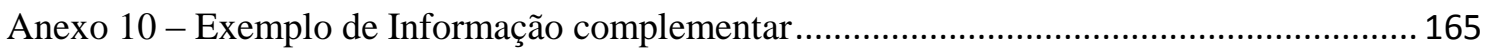

Anexo 11 - FICHA DE AVALIAÇÃO GUIA DO PNLD - Ensino Médio (2012).................... 166 


\section{CAPÍTULO 1}

\section{INTRODUÇÃO}

\section{Tópico de pesquisa, Objetivo geral e Justificativa}

Pensar em materiais didáticos (MDs) para o ensino de línguas estrangeiras, produzidos em função das necessidades, interesses dos aprendizes e teorias relevantes ainda no século XXI não parece uma prática habitual. A tendência do mercado editorial de línguas estrangeiras (LE) é publicar materiais que agradem a professores e alunos, em outras palavras, materiais que vendam. Geralmente, o que mais vende e agrada está ligado à cultura de aprender e ensinar, aceitas como naturais, com alguns argumentos buscados nas novas teorias de aprendizagem e ensino para reforçar a qualidade do produto (CORACINI, 1999, p. 20-21). Por exemplo, há muitos livros didáticos de LE identificados por seus autores como comunicativos, porém isso não quer dizer que o sejam.

Um caso recente de elaboração de MDs, com algumas dessas características, é o da Argentina. Nesse país, foram lançados no mercado editorial, livros didáticos de PLE produzidos por docentes reunidos em instituições particulares de ensino de português e autores independentes, também professores que atuam na área. Nesses livros didáticos, os autores declaram explicitamente haver se guiado por uma dada "abordagem" ou "teoria" em particular para compor os mesmos. Diante disso, venho propor uma "análise da abordagem" dos didáticos produzidos no país austral como o tópico central desta pesquisa.

Na Argentina, desde 1930 (PASERO, 2004), tem havido todo o tipo de propostas para incluir o português no currículo escolar. Todavia, algumas não tiveram o desenvolvimento desejado, e outras se tornaram rapidamente obsoletas (ARNOUX, 2007, p. 8). No entanto, desde que o Português do Brasil foi declarado língua oficial do MERCOSUL, junto ao Espanhol e ao Guarani, a demanda por seu ensino tem aumentado exponencialmente. Não obstante, a educação pública ainda não conte com os recursos necessários para garantir a oferta obrigatória da disciplina no ensino médio e fundamental - compromisso assumido em reiterados Acordos Bilaterais entre a Argentina e o Brasil e por meio da Lei 26.468 de 2008 (ARGENTINA, 2008). Sem 
considerar as províncias (estados) de fronteira, a oferta real da disciplina na escola pública se restringe a alguns centros educacionais da cidade de Buenos Aires (CABA), Córdoba e Entre Ríos. (ARGENTINA, MECyT, 2014)

O principal recurso faltante é um corpo docente com formação adequada para ensinar a língua nas escolas. No SEM (Setor Educacional do MERCOSUL) há uma Comissão Regional Coordenadora de Formação Docente (CRC FD) com um grupo de trabalho específico para a Formação de Professores de Português e Espanhol (MERCOSUR, 2011) que discute em suas reuniões essa problemática e promove no país a instalação dos programas de "profesorado" (equivalentes a licenciaturas) nas universidades públicas e nos Institutos de Formação Docente argentinos.

Perante esse panorama, as instituições privadas (escolas de línguas e escolas particulares) sempre foram as principais responsáveis pelo ensino de português em nível de escolarização e cursos livres. Assim, a crescente demanda nesse setor levou alguns diretores de instituições particulares e professores da área a discutir a necessidade de produzirem materiais didáticos próprios para seus estudantes. Essa valiosa iniciativa teve como fruto duas coleções de materiais didáticos para o ensino de português lançados no mercado argentino pela "Casa do Brasil" de Buenos Aires (Escola de Línguas) e duas professoras e autoras independentes de uma escola de PLE "Horizonte Brasil".

Interessa-me analisar a abordagem desses MDs em razão de haver vivenciado durante dez anos na Argentina, primeiro como aluna, depois como estagiária docente e finalmente como professora em formação continuada, a escassez de materiais didáticos comunicativos disponíveis no mercado para o ensino e aprendizagem de português tanto no âmbito público quanto no privado. Como aprendiz de um curso livre de PLE e como aluna do curso de graduação em PLE usei apostilas compostas de recortes de materiais de diversos livros como Avenida Brasil, Fala Brasil, gramáticas e livros de fonética, todos de cunho estrutural. Como estagiária docente, me deparei com o desafio de elaborar e selecionar materiais, já que as escolas públicas e particulares em que realizei meus estágios na província de Mendoza (durante quatro anos) não contavam com nenhum tipo de MD para ensinar o idioma. Como professora, não conformada com essa situação, resolvi aproveitar partes de alguns materiais menos estruturais disponíveis no mercado local e enfrentar a desafiante tarefa de compor minhas próprias "partituras" (ALMEIDA FILHO, 2013). 
Essa situação foi se modificando ao mesmo tempo em que a demanda pela aprendizagem formal da língua foi aumentando. As duas coleções de MDs supracitadas foram lançadas ao mercado Argentino em 2011, e são a fonte primária de dados para refletir (descrever e analisar) sobre a abordagem de ensino e aprendizagem e/ou aquisição de línguas implícita nelas. Logo, esta é uma pesquisa de análise documental, descritiva e de cunho interpretativista de duas coleções de materiais didáticos de português para estrangeiros hispanofalantes compostas por um livro do aprendiz, áudios e web sites de apoio (nenhuma das coleções possui livro do professor).

O tópico de pesquisa aqui proposto situa-se na subárea da Linguística Aplicada, "Aquisição e ensino de Línguas" (AELin). Na década de 80, a LA já contava com literatura preocupada com a necessidade de o ensino de português para o público hispanofalante ser diferente do ensino de português para falantes de outras línguas. Lombello et al. (1983), Almeida Filho (1995) e Simões et al. (2004) defendem essa postura a ser explorada no capítulo a seguir.

Para tratar da materialidade de produção e/ou seleção de MDs, a Operação Global de Ensino de Línguas (OGEL) proposta por Almeida Filho (1993) é parte medular do arcabouço teórico desta dissertação juntamente com outros construtos teóricos além “Abordagem”, proposto por esse autor e Anthony (1963) antes dele, e "Abordagem comunicativa e gramatical" e "Aquisição de L2" com a literatura de Almeida Filho (1993, 1997, 2012), Barbirato (1999), Ellis (1996), Skehan (1996), Prabhu (1988), Lombello et al. (1983), Littlewood (1981), Widdowson (1978) e Krashen (1982), Breen, Candlin e Waters (1999), entre outros.

De maneira geral, a pesquisa apresentada neste trabalho de dissertação tem o intuito de compreender quais são as características da abordagem de ensino aprendizagem e/ou aquisição dos materiais didáticos produzidos no país vizinho para o ensino de português a hispanofalantes. A seleção e/ou produção de MDs é uma das materialidades da OGEL, onipresente nas experiências que configuram o processo de ensino. Nas palavras de Almeida Filho (2012, p.58) os materiais didáticos

[...] possuem uma presencialidade vital na produção dos processos de ensinar e de aprender revelada por sua ubiquidade nas aulas e nas extensões das aulas como os deveres de casa ou o estudo mediado pelo material didático que nem sempre é o LD". 
Em outras palavras, o material didático constitui um recurso muito valioso nas aulas de língua estrangeira e suas extensões. Dentre os vários olhares lançados sobre a adoção de materiais há uma postura que se destaca: o professor faz uso constante de um livro didático e seus componentes, ele é o elemento central do curso e em muitos casos um apoio decisivo tanto para professores como para aprendizes, uma espécie de "Bíblia” segundo Coracini (1999, p.23). Essa postura afeta - ou determina - [...] o planejamento, os objetivos da aprendizagem, as competências a serem priorizados, os conteúdos a serem trabalhados e os tipos de atividades a serem propostas [...] (DINIZ, STRADIOTTI, SCARAMUCCI, 2009, p. 265).

Por isso, pretendo lançar um olhar analítico na recente produção argentina para compreender as abordagens de ensinar e de aprender língua que a permeiam, com o intuito de propor a "análise de abordagem" como um procedimento válido para professores de línguas adotarem, selecionarem, avaliarem materiais didáticos de LE previamente ao uso. Trata-se de uma maneira reflexiva de selecionar materiais didáticos baseada no conceito de abordagem que pode encorajar professores de línguas a assumir o papel de intérpretes das "partituras" (ALMEIDA FILHO, 2013) usadas nas suas aulas para deixar o papel passivo de seguidores de verdades incontestáveis registradas nos livros didáticos.

O compromisso da oferta obrigatória de língua portuguesa na Educação Pública argentina (ARGENTINA, Ley $\mathrm{N}^{\circ} 26.468,2008$ ) torna significativa esta pesquisa que busca compreender os traços característicos de abordagem dos MDs de PLE produzidos nesse país e propor um procedimento analítico-reflexivo de escolha de materiais prévia ao uso, para ser adotado por professores de línguas baseado na própria análise de abordagem dos MDs em questão. A Argentina ainda não conta com parâmetros como os do "Guia do PNLD” no Brasil para a seleção/avaliação de materiais didáticos. Logo, os resultados desta investigação poderão ser postos a serviço da educação pública argentina desde que as coleções analisadas tenham sido produzidas e utilizadas para o ensino de PLE naquele país vizinho.

\subsection{Objetivos Específicos}

Por meio da análise de abordagem viso a indagar se nos materiais didáticos de PLE escolhidos há: 
1) concepções de abordagem de bases teóricas diferentes.

2) algum tipo de apropriação da abordagem comunicativa e

Por último, a partir do estudo específico desses livros didáticos e da resenha de bibliografia, pretendo configurar:

3) um procedimento de escolha de materiais didáticos de LE prévia ao uso para professores, baseado em fundamentos teóricos e pressupostos da análise de abordagem. Em um plano de realidade futura, essa literatura poderia vir a auxiliar os professores da disciplina língua estrangeira quando se concretizar a oferta obrigatória de PLE nas escolas públicas argentinas.

Uma pergunta e uma subpergunta guiarão a busca de registros, discussão dos dados, linha de argumentação e conclusões, todas direcionadas a alcançar os objetivos da pesquisa:

1. Qual é a abordagem predominante nos MDs de PLE selecionados para esta pesquisa?

a- Quais traços da abordagem comunicativa e quais da abordagem gramatical esses materiais guardam?

\subsection{Estrutura da dissertação}

Neste primeiro capítulo, a introdução abrange o tema de estudo, seus conceitos eixo, a problemática, relevância e justificativa do tema em questão, apresentam-se os objetivos gerais e específicos, as perguntas guia da pesquisa e anuncia a estrutura do desenvolvimento da pesquisa.

No Capítulo 2, encontra-se a fundamentação teórica utilizada para a arguição temática e analítica deste trabalho de pesquisa. Constituem os conceitos centrais desse capítulo os indicadores constitutivos de uma abordagem, a diferença entre materiais e livros didáticos, as macroabordagens gramatical e comunicativa com seus matizes e um 
breve histórico tanto do ensino de português na Argentina quanto da produção de livros didáticos de PLE dentro e fora do Brasil.

O terceiro capítulo trata do referencial metodológico que me deu suporte para coletar, analisar e interpretar os dados. Também apresenta a fundamentação que identifica esta pesquisa como pertencente ao enfoque qualitativo-interpretativo e como um estudo de caso na modalidade de análise documental, com explicitação do caso e do contexto.

No Capítulo 4, a análise dos registros por meio de questões criadas especificamente para descrever e identificar as características de abordagem dos MDs em foco é o mote do capítulo. Os registros coletados nos MDs em função das questões estabelecidas foram analisados e interpretados com base nos fundamentos apresentados no capítulo teórico. No final desse capítulo, respondo as perguntas guia da pesquisa colocadas na introdução e proponho usar a análise de abordagem desenvolvida no capítulo como um procedimento analítico reflexivo válido para professores de línguas selecionarem e avaliarem os materiais didáticos que compõem as aulas das línguas que ensinam.

O quinto e último capítulo, considerações finais, conclui esta dissertação, retomando cada parte da mesma e apresentando suas limitações e contribuições. Finalmente são apresentadas sugestões para novas pesquisas e a conclusão final. 
FUNDAMENTAÇÃO TEÓRICA

\subsection{BREVE HISTÓRICO DO ENSINO DE PLE NA ARGENTINA}

Conforme afirmado anteriormente, a iniciativa de produção de materiais didáticos de PLE é muito recente na Argentina, ela é contemporânea à criação do MERCOSUL em 1991 e vincula-se à crescente demanda pelo ensino de PLE no país. Traçar uma breve análise de registros relevantes, da história desse ensino sustenta o estudo aqui realizado. Segundo Howatt (1984), os estudos históricos, permitem compreender e explicar o desenvolvimento do ensino de línguas num dado país. A resenha histórica do ensino de português na Argentina antes e depois do MERCOSUL permite compreender o desenvolvimento da área nesse país, o cenário atual e também “enxergar as necessidades específicas para a internacionalização e o desenvolvimento do ensino de português como uma língua de integração regional" (CASTRO, F.T; GONZÁLEZ, V.A et al, 2013).

\subsubsection{O antes do MERCOSUL}

A primeira tentativa nacional para desenvolver o ensino da língua portuguesa na Argentina situa-se entre 1932 e 1942, coincidindo com o florescimento da divulgação da cultura brasileira e a assinatura de um "Tratado de Comércio e Navegação" durante os governos dos Presidentes Pedro A. Justo e Getúlio Vargas. Nessa época, o Brasil era o quarto parceiro comercial da Argentina e ambos os governos se reuniam em várias ocasiões para resolver conflitos relacionados aos limites fronteiriços entre o Paraguai e a Bolívia e assuntos relativos à Primeira Guerra Mundial (PASERO, 2004).

Em 1936, enquanto foi criado o primeiro "curso livre" de português no "Instituto Nacional del Profesorado Secundario”, o presidente do Conselho Nacional de Educação desse período, Ramón J. Cárcano, reafirmava uma ideia que impulsionava desde 1932, a possibilidade de oferecer cursos de português nas escolas primárias para adultos na Capital Federal. Outras ações se sucederam nesse período: a tradução e edição da "Biblioteca de Autores Brasileños Traducidos al Castellano", o funcionamento do 
Instituto Argentino-Brasileiro de Cultura e as aulas alusivas ao Brasil (CONTURSI, 2012).

Entretanto, o português começou a ser oficialmente ensinado em 1943 com a aprovação do Projeto de Lei 12.766 (PASERO, 2004), do deputado nacional e jornalista, Raúl Damonte Taborda, no quinto ano das escolas secundárias do Ministério de Justiça e Instrução Pública e como ‘disciplina de especialização’ nos currículos dos "Institutos de Profesorado" (CONTURSI, 2012). Segundo Franzoni (1999), onze anos depois, o governo de Getúlio Vargas criou, em Buenos Aires, o Centro de Estudos Brasileiros (atual CCBA -Centro Cultural Brasil-Argentina). Com os esforços anteriores e a assinatura de acordos bilaterais de cooperação cultural, entre 1958 e 1968, somente em 1971, a oferta de português se expandiria em quatro escolas da Capital Federal nos dois últimos anos do ensino médio (id).

Em 1957, o Decreto 1270/57 modificou os planos de estudos dos "profesorados" de línguas estrangeiras e deixou implícita uma grande vontade de introduzir o "método direto" na formação de professores de LE (BEIN, 2012), que foi acunhado só em 1963 no decreto fundacional $n^{\circ} 1654 / 63$ do "Instituto Nacional Superior del Profesorado en Lenguas Vivas Juan R. Fernández”. No ano anterior, a mudança dos planos de estudo da escola secundária, com o decreto 6680/56, apenas trazia novidades para o ensino de inglês e francês.

Durante os governos militares (1955-1973 e 1973-1983), o inglês ganhou uma especial preferência pelo momento de subordinação econômica aos Estados Unidos e pela Guerra das Malvinas de 1982. Com a volta da democracia, a Resolução Ministerial $\mathrm{N}^{\circ} 2.617$ de 1985, autorizou o ensino de português na Capital Federal e dois anos depois na Grande Buenos Aires, em uma turma do ensino médio nos colégios sem orientação específica e com orientação em Letras (FRANZONI, 1999).

No final dos anos 80, houve outros acontecimentos importantes: aprovou-se o currículo das disciplinas da Licenciatura em Português e o curso de "Investigación y Especialización en Português", do "Instituto Nacional Superior del Profesorado en Lenguas Vivas", e o currículo acadêmico do mestrado em "Ciencias del Lenguaje" do "Instituto Superior del Profesorado Joaquín V. González", que estabelecia duas disciplinas obrigatórias anuais de língua portuguesa (id). 


\subsubsection{O depois do MERCOSUL}

Em 1991, com a assinatura do tratado do MERCOSUL, o português e o espanhol foram declarados idiomas oficiais dos países membros para estabelecer um critério de publicação dos documentos. Inicialmente, nada se citou sobre o ensino de línguas e os aspectos sociais, culturais e educacionais foram aparecendo ao longo do tempo e na medida em que esses aspectos surgiam eram criadas as soluções (CONTURSI, 2012).

Para Arnoux (2007) e Contursi (2012), durante a década de noventa, o tratamento dado ao português foi como língua de trabalho intergovernamental. A reforma da Lei Federal de Educação 23.695 funcionou como marco geral do ensino de línguas. Cada jurisdição devia oferecer obrigatoriamente um nível de inglês como LE de comunicação internacional e outros dois níveis de "outra LE" conforme as necessidades regionais (CONTURSI, 2012).

Anos mais tarde, em 1997, a Argentina e o Brasil assinaram um "Acordo de Integração Cultural Brasil-Argentina" no qual consta no parágrafo dois do "Art. I Cooperação em Cultura, Arte e Ensino de Idiomas", que cada parte apoiaria, com base na reciprocidade, as atividades que se realizarem no território desse Estado em favor da difusão do idioma e das expressões culturais e artísticas do outro estado (CRISTOFOLI, 2010). Dessa maneira surgiu o SETOR Educacional MERCOSUL (SEM), como resultado da assinatura de um protocolo de intenções novamente por parte dos Ministros de Educação.

Como acontecera antes de 1991, os acordos bilaterais não garantiram a oferta de português nas escolas públicas. No entanto, em 1999, a assinatura de um novo convênio fez com que, de imediato (em 2000), o governo argentino aprovasse um "Programa de Português a distância”, com o intuito de formar profissionais para o ensino do idioma (CONTURSI, 2012) e em 2005, o SEM estabeleceu, entre suas metas para 2006-2010, a criação de centros de estudos de língua e literatura dos idiomas oficiais do MERCOSUL (CRISTOFOLI, 2010).

Nesse contexto, foram sancionadas em 2006 e 2008, respectivamente, as Leis $\mathrm{N}^{\circ}$ 26.206 e 26.468. A primeira decretou a obrigatoriedade de conteúdos curriculares de LE relacionados ao MERCOSUL e a segunda estabeleceu que todas as escolas secundárias elaborariam obrigatoriamente um plano curricular para o PLE e o "Instituto Nacional de Formación Docente" um plano "plurianual” para a formação de docentes. Por último, 
em 2011, no seu plano de ação para 2011-2015, O SEM criou uma Comissão Regional Coordenadora de Formação Docente que tratará, até 2015, sobre a Formação de Professores de Português e de Espanhol, entre outros assuntos.

Para acompanhar a realidade do PLE, em 1997, nasceu a "Asociación Argentina de Profesores de Portugués" (AAPP), que tem desempenhado um papel de destaque nos esforços nacionais para a sanção de leis sobre a incorporação do português ao currículo escolar e à formação de professores. Recentemente, a AAPP manifestou-se formalmente contra a medida arbitrária e contraditória da "Dirección de Educación Superior de la Provincia de Buenos Aires" que fechou duas licenciaturas de português desse estado.

Historicamente, as instituições privadas atenderam a demanda crescente do português e deram início, em 1997, à publicação de seus próprios livros didáticos. (Ver Tabela 3 na próxima seção). Atualmente o país conta com cinco coleções de edição nacional, elaboradas para o ensino a hispanofalantes. Em duas delas foca-se o estudo desta dissertação. Na próxima seção retomarei o assunto com mais detalhes.

Por fim, é importante destacar que depois do MERCOSUL, o português ganhou encontros, seminários e congressos nas Universidades e Institutos de Formação Docente de todo o território nacional.

Nas reflexões de Arnoux (2007), não podemos negar que nos últimos vinte anos, o português, uma língua que não era visível, começou a tornar-se notório. Todavia, algumas das experiências ou propostas quanto ao ensino dela não tiveram o desenvolvimento desejado, e outras foram inócuas. Em 2014, ainda há poucas informações sobre o ensino de português em nível secundário de escolarização. Por outro lado, para a formação de professores, há unicamente dezesseis "profesorados" de Português distribuídos nas províncias de Buenos Aires, Córdoba, Corrientes, Mendoza, Misiones e Santa Fé (ver Apêndice 1).

Desde 1930, as raízes do ensino de PLE na Argentina estiveram ligadas a Tratados e Acordos Comerciais, Culturais e Educacionais . Passaram-se 83 anos da primeira vez que no Conselho Nacional de Educação se discutiu a ideia de oferecer cursos de português nas escolas primárias (Ver Apêndice 2 - Linha do Tempo) . Não obstante, no decorrer desta seção, vimos que o lugar do português no currículo escolar argentino e a oferta de licenciaturas dessa língua, entre avanços e percalços, ainda é alvo de polêmicas e controversas decisões e múltiplos esforços nacionais e regionais, 
públicos e privados, que almejam ver o ensino de PLE além dos bastidores (ARNOUX, 2007; GIL, 2009 e FRANZONI, 1999).

Nesta seção dei um panorama histórico e atual da situação em que se encontra o ensino de português na educação pública argentina. A seguir, será abordada a materialidade "Material Didático" para mergulhar nos livros de PLE especificamente e entender como funciona essa tarefa na vida dos docentes de línguas estrangeiras. Argentina.

\subsection{A ONIPRESENÇA DO MATERIAL DIDÁTICO NA OGEL}

\subsubsection{Materiais didáticos ou Livros Didáticos?}

Segundo o Glossário de Linguística Aplicada (GLOSSA, grifo meu) os materiais didáticos são "a segunda de quatro materialidades praticadas por um professor de língua em seu ofício. Materiais são codificações de ação para que professores e alunos produzam ações para fazer a nova língua nas salas de aulas e nas suas extensões. Todo material tem de ser apreendido em seus propósitos e tornado vivo no desempenho de professores e seus aprendentes. Ao tentarem se apropriar do material, os agentes primeiros e segundos dos processos de ensinar e de aprender ou adquirir línguas devem estar abertos às adaptações, modificações e ajustes às necessidades e desejos de professores e alunos" (grifo meu).

Os MDs são os grandes aliados do professor nas práticas educativas, inclusive nas aulas de língua estrangeira. É comum que façam parte do planejamento do curso e sejam o guia da abordagem que permeia a sala de aula. No modelo da Operação Global de Ensino de Línguas (OGEL) proposto por Almeida Filho (2010, p. 17), a produção e/ou adoção de materiais didáticos constitui uma das quatro materialidades onipresentes nos processos de ensinar e de aprender nas aulas e suas extensões. Cabe salientar que o material didático nem sempre é o livro didático (LD) (ALMEIDA FILHO, 2012, p. 58). Esse último pode trazer implícitos vários materiais didáticos. Por isso, nesta dissertação adoto essa última acepção para me referir às duas obras didáticas analisadas. Diversos autores da Linguística Aplicada já definiram o termo materiais didáticos: 
a- Tudo que é usado pelos professores ou alunos para promover o aprendizado de uma língua: livros, exercícios fotocopiados, folhetos, palestras, jornais, vídeos, todos são MDs para o autor. (TOMLINSON, 1998, p. 2)

b- São os reais eventos discursivos que constituem as lições. (PRABHU, 1988, p. 95-96)

c- São os livros didáticos que fornecem a base ou núcleo de materiais que funcionam como ignição para o professor e a classe. (O`NEILL, 1982)

Na opinião de Gotheim (2007, p. 51-52) a definição desses autores é difusa já que definem os didáticos como qualquer situação discursiva em sala de aula (um vídeo, perguntas dos alunos, explicações da professora). A visão da autora (op. cit.) coincide com a do Glossário de Linguística Aplicada (op. cit.). Para ela

\begin{abstract}
Materiais [...] referem-se a todo insumo codificado em textos, fotos, falas, gestos (em disposição específica), vazados em linguagem verbal ou não verbal, criados com a função potencial de gerar experiências de aquisição /aprendizagem de língua.
\end{abstract}

Prabhu (1988) diferencia os MDs dos LDs quando assevera que esses últimos são os que procuram prover todos e os únicos insumos a serem apresentados aos alunos, em uma sequência pré-concebida como uma agenda de lições. $O$ autor diz que o material didático deve ser tão flexível a ponto de não objetivar, predizer ou predeterminar o que deve ou não ser considerado adequado para a aprendizagem. Esse tipo de material é denominado por ele como "material-fonte" já que durante seu uso há possibilidades de modificá-lo, adaptá-lo e ajustá-lo às necessidades de professores e alunos, considerando os conhecimentos prévios dos aprendizes e os insumos fornecidos pelo professor. Para Prabhu (1988), um MD não deve ser centralizado, exaustivo, ou seja, quando ele está na mão do professor não deve apenas dar lugar a pequenos arranjos como se fossem concessões dos produtores. Por isso, Almeida Filho (2013, p. 15-16) sustenta a ideia de produção de materiais incompletos, "como se fossem planos incompletos aguardando uma finalização de professores e suas turmas nos contextos reais em que estiverem imersos". Esse autor (ibid), propõe a metáfora (citada na introdução deste trabalho) de materiais didáticos como "partituras", uma base 
codificada com sugestões para serem transformadas na "ação ensinadora e adquiridora" com apoios de recursos que podem limitar ou aumentar as chances de aquisição dos aprendentes.

Para o Glossário de Linguística Aplicada (GLOSSA), um livro didático é um tipo de material impresso geralmente usado como principal fonte de insumo na sala de aula e na sequencia em que foi concebido. Livros didáticos na sua maioria são obras que contém trabalho com gramática, vocabulário, pronúncia, funções, leitura, escrita, compreensão e produção de linguagem oral. Vejamos um quadro comparativo do conceito de MD e LD:

Tabela 1 - Material Didático x Livro Didático

\begin{tabular}{|c|c|}
\hline Material didático & Livro Didático \\
\hline $\begin{array}{c}\text { Insumo codificado e codificações de ação para } \\
\text { que professores e alunos produzam ações para } \\
\text { experienciar a nova língua nas salas de aulas e } \\
\text { nas suas extensões. }\end{array}$ & $\begin{array}{c}\text { Material impresso composto sequencialmente } \\
\text { por conteúdos de gramática, vocabulário, } \\
\text { pronúncia, funções, leitura, escrita, áudios, } \\
\text { exercícios. Pode trazer implícito vários materiais }\end{array}$ \\
\hline $\begin{array}{c}\text { Gera experiências de aquisição/aprendizagem } \\
\text { da nova língua }\end{array}$ & $\begin{array}{c}\text { Traz uma sequência preconcebida para ser } \\
\text { seguida por professores e alunos. }\end{array}$ \\
\hline $\begin{array}{c}\text { Fonte de insumo e ações para potenciar as } \\
\text { oportunidades de comunicação na nova língua }\end{array}$ & $\begin{array}{c}\text { Traz o máximo de insumo num só volume e é o } \\
\text { único livro usado durante o curso. }\end{array}$ \\
\hline $\begin{array}{c}\text { É complementado pelas ações de professores } \\
\text { e aprendizes na sala de aula e suas extensões }\end{array}$ & $\begin{array}{c}\text { Pode inibir a iniciativa e criatividade do } \\
\text { professor quando suas abordagens estão em } \\
\text { discordância. }\end{array}$ \\
\hline
\end{tabular}

Fonte: Almeida Filho (1993), Glossário de Linguística Aplicada (GLOSSA) Gotheim (2007), Tomlinson (1998)

Assim sendo, na análise dos registros, do capítulo 3, como consequência da análise de abordagem veremos se as coleções didáticas selecionadas se perfilam com materiais mais completos, como os LDs, ou MDs com espaço para professores e aprendizes atuarem como intérpretes da obra. Na pesquisa relatada nesta dissertação, adotei os conceitos de "MD" e "material fonte" supracitados por acreditar que são os mais adequados para produzir e selecionar fontes de insumo para atingir os objetivos de ensino e aprendizagem de uma LE na sala de aula e suas extensões. 


\subsubsection{A produção e/ou seleção de MDs na OGEL}

A "produção e/ou adoção de materiais didáticos" na OGEL é a única materialidade que ostenta no seu nome o termo "material" (ALMEIDA FILHO, 2012, p.58). Segundo o autor, isso acontece porque os MDs são onipresentes na produção dos processos de ensinar e de aprender. As ações de ensino nas aulas quase sempre são mediadas pelo material didático, assim como suas extensões, as atividades para a casa, por exemplo. Vejamos o lugar específico da materialidade "produção e/ou adoção de materiais didáticos" no modelo ampliado da OGEL (grifo meu):

Figura 1 - Modelo Ampliado da Operação Global de ensino de Línguas

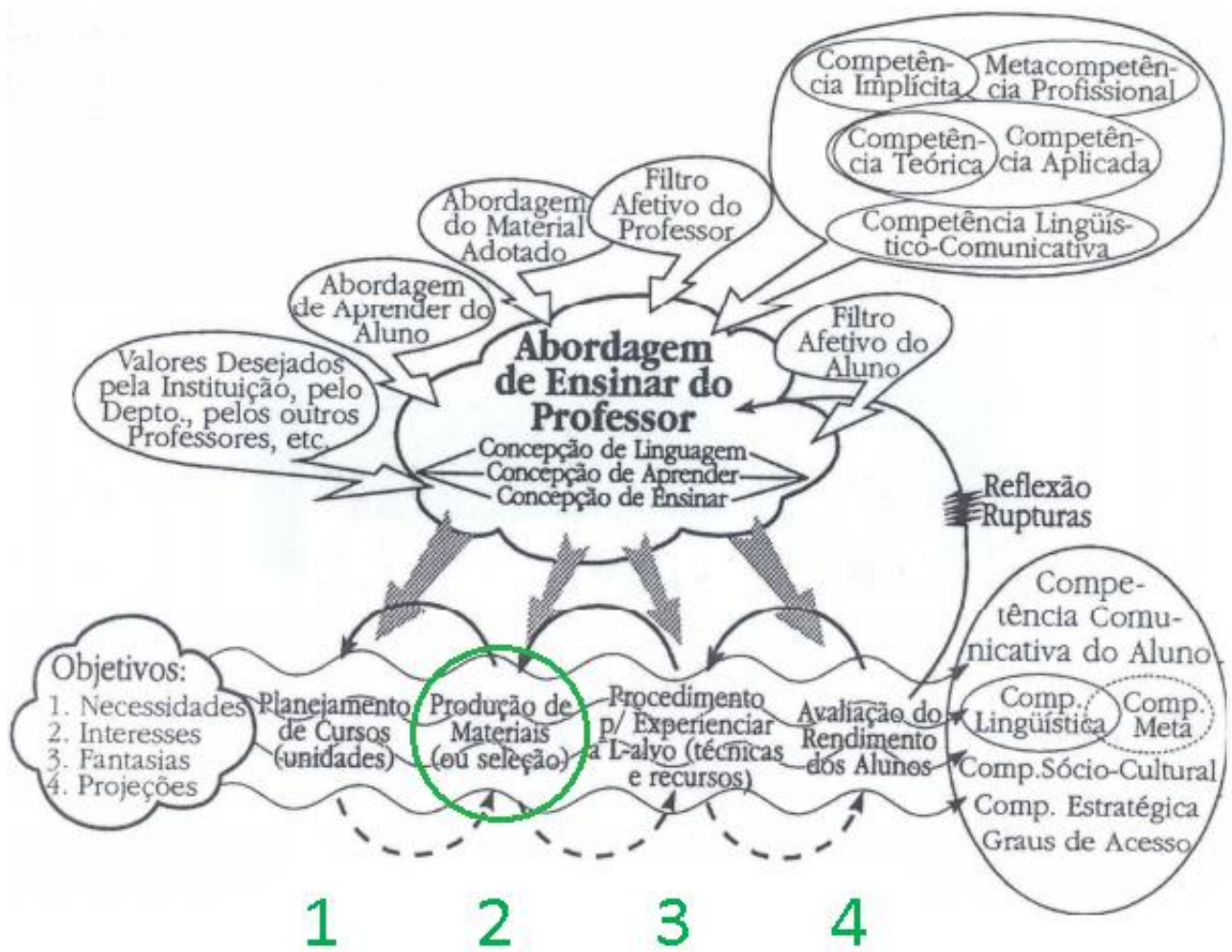

Fonte: ALMEIDA FILHO (2013, p.22) com acréscimos da autora em verde.

No modelo acima, as quatro materialidades designadas pelos algarismos de $1 \mathrm{a}$ 4, representam as tarefas que aguardam o professor de LE quando esse se propõe a ensinar uma dada língua-alvo (ALMEIDA FILHO, 1993, p. 17). Essas tarefas são: 1) o planejamento do curso, 2) a produção ou seleção de MDs que codificam a ação posterior das experiências, 3) as experiências nas aulas e suas extensões (o método) e 4) a avaliação do rendimento ou proficiência dos alunos (critérios para produzir 
instrumentos). Todas essas fases estão relacionadas entre si, ou seja, uma alteração feita numa delas pode trazer mudanças em cadeia nas outras fases à frente (proativas) ou para trás (retroativas). Assim, a produção e/ou seleção de MDs com seus critérios para codificação pode acarretar mudanças retroativas sobre o planejamento do curso e proativas sobre o método escolhido e a futura avaliação do rendimento.

O conjunto das quatro ações de ensino do modelo da OGEL é executado pelo professor orientado por uma determinada abordagem, isto é, o professor, na sala de aula e suas extensões, antes e depois da aula, em atuação profissional, age de acordo com uma determinada "filosofia/concepção" sobre o que é língua, linguagem humana, ensinar, aprender e/ou adquirir uma nova língua. No entanto, a abordagem do professor não é a única força codificadora da construção do processo de ensino e aprendizagem/aquisição (ALMEIDA FILHO, 2012, p. 21, grifo meu):

\begin{abstract}
Além dos filtros afetivos do próprio professor e dos alunos que conjugam motivação, bloqueios, ansiedades, pressões dos grupos, cansaço físico e oscilações eventuais enquanto forças de contraponto numa dada configuração, a abordagem do professor ainda tem de se relacionar com outras forças potenciais. Aí estão incluídas a abordagem de aprender do aluno, a abordagem de ensino subjacente ao material didático adotado e os valores desejados por outros no contexto escolar (a própria instituição, o diretor, os outros professores líderes, com maior antiguidade e/ou maior poder dentro do corpo docente)
\end{abstract}

Para a análise da abordagem de ensino subjacente ao material didático que dedicarei os esforços nos próximos capítulos. A análise de abordagem é um procedimento específico que permite "determinar os contornos e essências de uma dada abordagem de ensinar no quadro de forças em que ela forçosamente ocorre" (ALMEIDA FILHO, 2012, p. 23). Alguns autores (ALMEIDA FILHO 2010, FONTÃO, 1991) têm manifestado que a análise de materiais didáticos sem contemplar seu uso efetivo durante as aulas e fora delas pode resultar em um estudo incompleto. Essa é uma das limitações do trabalho de pesquisa aqui apresentado. No entanto, empregar esse procedimento permite compreender abordagens predominantes dos processos de criação dos materiais e suas possíveis consequências e equações/convergências/projeções (uma vez que esse material é colocado em ação) com as abordagens dos outros agentes. $\mathrm{Na}$ seção 2.3.2 deste capítulo, retomarei a fundamentação teórica desse assunto. 


\subsubsection{As facetas da materialidade "Material Didático" na OGEL: processos de criação e adoção}

Com base na OGEL, vejo duas facetas na materialidade "Material didático": os processos de criação, por um lado, e os processos de adoção, pelo outro. Ambos os processos com seus agentes estão imbuídos de Teoria para com ela codificar, selecionar e adaptar os MDs que irão levar para a sala de aula e suas extensões. Como acontecem os processos de produção e seleção de MDs na OGEL? Quem são os agentes e suas responsabilidades nesses processos? Esses são os principais questionamentos que mobilizaram esta seção. Para respondê-los, começarei situando as condições necessárias ao ensino de uma língua, analisando qual é o lugar da materialidade "Material Didático" para desembarcar nas abordagens/conceitos que mobilizam os agentes a compor e selecionar MDs na OGEL da maneira como o fazem.

Para Almeida Filho (1993, p. 21), as ações de ensino podem se iniciar quando houver uma abordagem de ensinar apoiada no mínimo por uma competência implícita (intuições, crenças, experiências) e uma competência linguístico comunicativa (capacidade para operar em situações de uso da nova língua) na presença de potenciais alunos aprendizes. Outras competências como a aplicada e a profissional são também almejadas para o professor desenvolver plena consciência do que ensina (competência aplicada) e de seus deveres sociais no exercício da sua profissão (competência profissional).

Assim, a partir de uma abordagem apoiada, no mínimo, pela competência implícita e competência "linguístico comunicativa", o professor inicia a grande operação de ensino e aprendizagem de uma nova língua. Vários cenários e agentes se apresentam no início desse processo da ótica da criação e/ou adoção de MDs:

a- O professor tem um planejamento pronto e um LD (livro didático) já escolhido. Nesse caso, o planejamento do curso está implicitamente ditado pelos compositores do MD (ALMEIDA FILHO, 1993, p.21) e são quase inexistentes as chances dos adquirentes participarem do processo manifestando seus interesses e objetivos para incorporar outros materiais já que o livro didático é seguido em sequência pelo professor para cumprir o planejamento consequentemente. Uma variante da situação anterior pode trazer adaptações e modificações no MD e planejamento quando o professor 
está aberto às necessidades e desejos próprios e dos seus alunos (Glossário de LA, www.glossario.sala.org.br/).

b- A sessão de ensino e aprendizagem começa com o levantamento dos interesses temáticos e objetivos dos aprendizes para a seleção ou produção do material didático a ser empregado durante o curso nas aulas e suas extensões. Nesse caso o planejamento também será ditado pelo MD (ALMEIDA FILHO, 1993).

c- O processo também começa com a sondagem dos interesses temáticos e objetivos dos alunos para com eles codificarem o planejamento do curso e posteriormente os materiais didáticos. Geralmente neste caso os materiais são criados por professores, professores pesquisadores ou uma equipe de pesquisadores composta por professores mestres e/ou professores doutores.

d- Outro caso para dar início ao processo pode não ter nem planejamento nem materiais previamente construídos. Trata-se de uma situação extrema em que “...o professor cria espontaneamente materiais de improviso (geralmente pela fala) que o aluno toma como material impromptu ou insumo potencial para desenvolver sua interlíngua ou competência." (ALMEIDA FILHO, 1993, p.21)

Dados os quatro cenários brevemente caracterizados acima, é possível identificar os processos e agentes envolvidos na materialidade "Material Didático". Por um lado, temos a criação, e pelo outro, a adoção/seleção (com ou sem adaptações). Os agentes envolvidos nesses processos podem ser os "compositores", "professores" e/ou os próprios "aprendizes". Adoto o termo "compositores de materiais" do Prof. Almeida Filho (2013, p.18) já que ele explica que “... compor é codificar um desempenho futuro..." e também quer dizer que a autoria só é completa quando executada a composição, ou seja, quando o material é usado como provocador de aquisição da LE. Segue um desenho representando as facetas identificadas nessa materialidade: 
Figura 2 - Facetas da materialidade "Material didático"

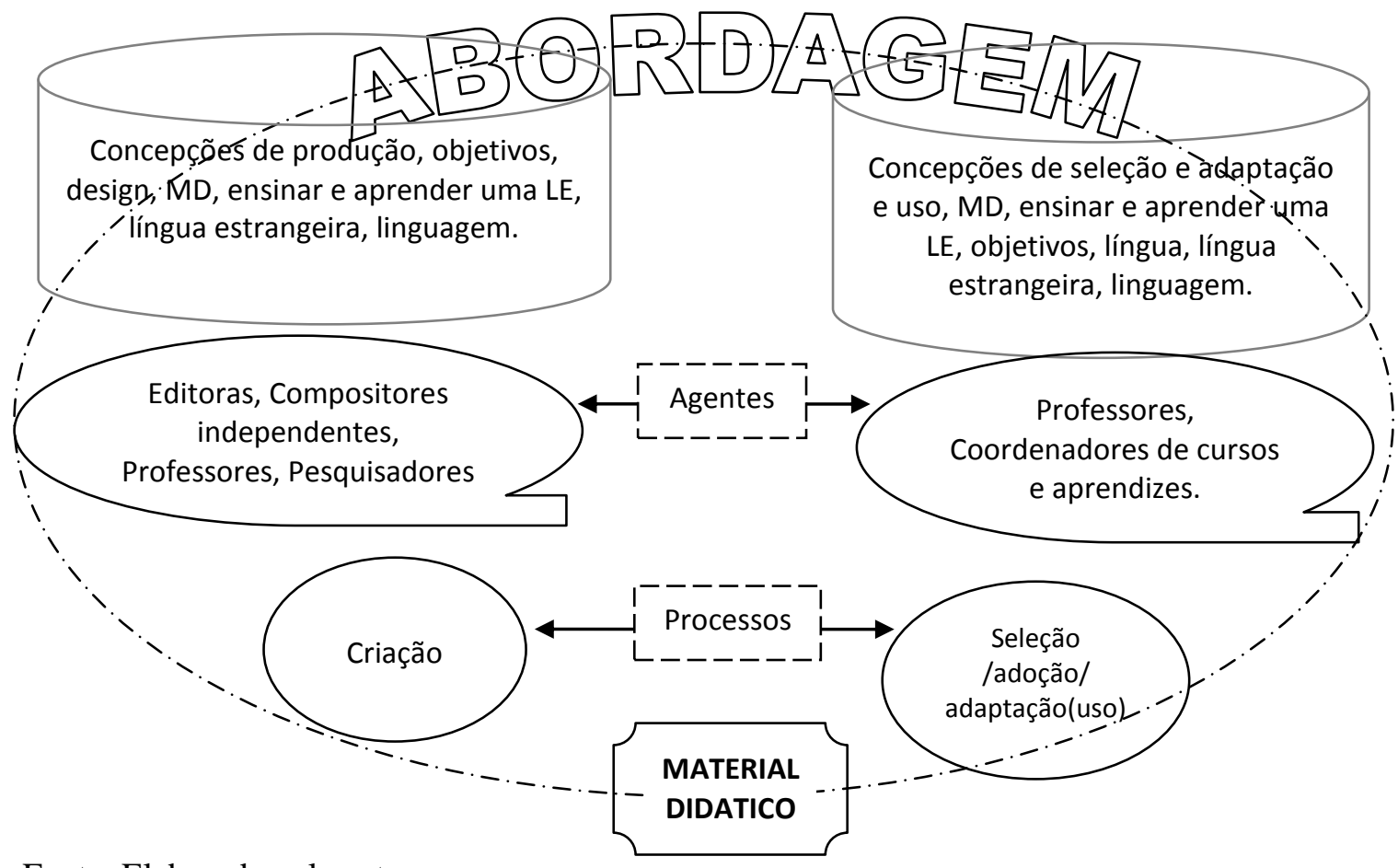

Fonte: Elaborado pela autora

Do ponto de vista dos agentes que criam materiais, o processo de criação envolve a composição consciente e com autoria (ALMEIDA FILHO, 2013, p.14) de

[...] um roteiro por escrito do que deve ser feito pelos professores investidos da função de dar vida a atividades ou experiências na língua alvo desejada pelos aprendentes nos grupos formados em classes coletivas ou em aulas particulares.

Seguindo essa ótica, os professores também assumem o papel de compositores de materiais escritos e orais no processo de criação. Como no caso "c" descrito acima, os professores podem escrever previamente seus materiais e também "dizer oralmente certos materiais em sala de aula" (ALMEIDA FILHO, 2013, p. 13 e 14). Um exemplo disso é quando o professor "inventa ou improvisa" MDs orais relevantes durante suas aulas, como no caso "d" supracitado, ou ainda quando, com um material previamente adotado, o professor o complementa com criações próprias. Especificamente para o papel de compositor de materiais escritos, o professor precisa de formação docente continuada, em Teoria relevante, e experiência em diferentes âmbitos de ensino, assim como de uma equipe de assessores (pesquisadores mestres e/ou doutores) para 
orientação e avaliação da composição (ALMEIDA FILHO, 2012, p. 62 e 63). Essas são algumas das exigências que demanda o processo de criação de MDs.

Por sua vez, há compositores ligados a editoras de grande porte e no outro extremo, compositores independentes (geralmente professores) que diagramam seus materiais e os reproduzem em uma gráfica. Os pesquisadores, geralmente mestres e/ou doutores, também participam do processo de criação de MDs com formato de módulos (vide Norimar Júdice, 2013), livros didáticos (como os analisados nesta dissertação) ou materiais apostilados (vide Gotheim 2007 e Mendes 2004). Essas produções, todas específicas para cursos de PLE, fruto de pesquisas comprometidas com teoria relevante, raramente são publicadas devido aos empecilhos que os autores enfrentam para obter autorização ou pagamento aos titulares dos direitos das obras protegidas que nesses materiais são usados. Isso traz um efeito desfavorável à área do ensino de línguas, pois grandes editoras concentram o poder de publicação de livros didáticos perpetuadores, na maioria dos casos, de culturas de ensinar e de aprender tradicionais que vendem. Segundo Carolina Rossini (2010), autora do relatório "The State and Challenges of Open Educational Resources in Brazil From Readers to Writers" e coordenadora do projeto "Recursos Educacionais no Brasil: Desafios e Perspectivas", em entrevista a um jornal on line disse que a falta de maior flexibilidade dos direitos autorais em relação a usos educacionais impede, por exemplo, que um professor - mesmo no âmbito de diretrizes curriculares, crie seu próprio livro a partir do remix de materiais que considere mais adequados a sua sala de aula ou a cada um dos aprendizes.

A segunda faceta da materialidade material didático, a seleção/adoção (com ou sem adaptações), é tarefa de "todos os professores profissionais independentemente da sua experiência" (ALMEIDA FILHO, 2012, p. 61). A ação de selecionar um determinado material didático implica julgar que as atividades, conceitos implícitos de aprendizagem e ensino, textos, áudios, atividades, entre outros, são adequados para desenvolver o conjunto de ações de aprender e ensinar uma língua a um público determinado, ainda que o material adotado não tenha sido produzido para atender os objetivos, necessidades de aprendizagem e interesses temáticos daquele público. Nesse caso, como afirmado anteriormente os agentes, professores e aprendentes, devem estar abertos às adaptações, modificações e ajustes às necessidades e desejos deles. Para isso são necessárias as competências aplicada e profissional além da implícita e linguístico comunicativa. 
Ellis (1997) chama o processo de seleção de materiais como "avaliação". O autor distingue a "avaliação prévia" (antes do uso) da "retrospectiva" (posterior ao uso). Na primeira, o professor seleciona o material mais adequado de maneira improvisada ou pode usar guias concebidos por pesquisadores especializados na teoria de MDs (vide Breen e Candlin, 1987, Cunningsworth, 1984, Skierso, 1991) para tomar decisões sobre qual é o didático mais adequado à situação de ensinar e aprender em que se encontra. Depois de usado o MD, precisa-se avaliar em retrospectiva quais atividades funcionaram com os aprendizes e quais não, para decidir como modificar os materiais com visão de uso mais efetivo, no futuro. Por outro lado, a avaliação retrospectiva funciona como uma espécie de teste de validação dos princípios ou pressupostos de seleção dos materiais e pode vir a dar ideias de melhorias e mudanças neles.

Cabe salientar que quando os professores agem como compositores, autores ou selecionadores de materiais didáticos, concretizam os processos de criação ou seleção de materiais da maneira como o fazem, guiados por determinada abordagem (teoria, Teoria, concepções de língua, linguagem, aprender, ensinar, visões de mundo, conceitos de produção, objetivos de ensino e aprendizagem, crenças) que no quadro de forças da grande operação de ensinar línguas se conjuga/equaciona com a "cultura de aprender dos alunos". Chama-se cultura de aprender as maneiras de aprender "naturalizadas", quase inquestionáveis, geralmente construídas pelas escolas e pelos meios de comunicação para atingir com êxito seus objetivos (CORACINI, 1999, p. 21).

Esse fenômeno também acontece com os compositores de MDs vinculados a editoras. No entanto, na maioria das vezes, são as editoras quem dão a concepção de produção que o compositor deve seguir. Segundo Tomlimson (2013, p. 40 e 41), no caso de MDs para o ensino de inglês, as editoras dão aos seus "escritores de materiais" listas de tópicos tabus ou provocativos de discussão que não devem usar para compor as obras didáticas. Coracini (1999, p. 20 e 21) afirma que as editoras e os autores de livros didáticos procuram "agradar os destinatários" e para isso se baseiam em pesquisas feitas junto a alunos e professores "com a finalidade de detectarem o que mais vende". A própria autora reflete que o que mais vende geralmente coincide com a cultura de aprender naturalizada como a maneira "certa". Cabe salientar, que a maioria dos 
materiais didáticos de PLE criados e publicados na Argentina e no Brasil é produto de criações independentes de professores experientes a eventuais pesquisadores (poucos). Retomarei esse assunto para discussão na seção e capítulos subsequentes.

"Em nove dentre dez casos ocorre uma adoção de MD produzido por outros ou terceiros" (ALMEIDA FILHO, 2012. p 61). Isso quer dizer que produzir um material, da ótica do profissional do ensino não é uma tarefa simples. Selecionar é automaticamente associado e exigido do professor, não por isso uma tarefa para a qual todos os professores estejam preparados. Para Gothein (2007, p. 16) selecionar e adaptar um MD exige "preparo e experiência"

[...] as ações de procura de novos textos e a criação de atividades que suplementem conteúdos do livro didático implicam decisões avaliativas que, para serem geralmente realizadas, carecem de fundamentação teórica explícita, a qual justifique objetivos e escolhas de tirar, pôr e compor textos e atividades. Quando realizava adaptações, o programa culminava numa colcha mal-arrumada de retalhos, que pouco acrescentava à minha formação pedagógica continuada.

Produzir pressupõe muitas exigências, é uma atividade mais específica e desafiadora (op. cit.) e uma experiência pouco transitada nos cursos de Letras do Brasil e da Argentina. O professor Almeida Filho (2012, p. 62 e 63), também afirma essa ideia ao enumerar várias exigências que os processos de produção de materiais presumem para seus agentes:

1- experiência de ensino em variados contextos;

2- fundamentação teórica adequada na área de aquisição e ensino de língua;

3- acompanhamento e orientação da produção e avaliação do MD por um corpo de assessores mestres e/ou doutores ;

4- competência comunicativa (CC) completa na língua impregnada na produção. Professores e/ou produtores com limitações de trânsito e criatividade na LE devem encontrar suporte em outros mais fluentes;

5- disponibilidade de um assessor de alta proficiência e familiaridade com aspectos culturais da língua para revisão dos textos, atividades, aspectos 
ideológicos relevantes, estilos, estratégias requeridas, representação étnicocultural adequada;

6- empreendedorismo e criatividade na marca de design;

7- capacidade prática em identificar tipos variados de materiais necessários ao curso;

8- capacidade reflexiva para fazer o material crescer com modificações e adaptações no "atendimento de demandas específicas do público a que ele se destina";

9- tempo disponível para analisar, revisar e observar o uso do MD por outros professores;

10-perseverança nos objetivos e aperfeiçoamento do MD até ele encerrar seu ciclo por esgotamento de suas bases e potencial;

Ao longo desta seção quis evidenciar que os processos de produção e seleção e/ou avaliação de MDs acontecem de maneira complementar. Ambos requerem formação reflexiva dos agentes envolvidos e o exercício de suas competências. No entanto, o processo de seleção parece ser menos exigente, ainda que não se trate de uma tarefa simples. É esperado que todo professor com ou sem experiência escolha materiais didáticos para o ensino de uma LE e faça eventuais adaptações. Não obstante, não é exigido que o professor de línguas crie seus próprios materiais. Esse processo prescreve muito mais do que simples empreendedorismo e criatividade. Por outro lado, salientei que os dois processos são conduzidos na sua gênese por concepções sobre o que é ensinar e aprender uma LE, língua, linguagem, crenças, Teoria relevante, MD, entre outros. Essa abordagem dos agentes permeia a seleção e composição de materiais de língua estrangeira que é levada pelos professores no formato do livro didático à sala de aula e suas extensões em que entra em tensão com o quadro de forças de todas as abordagens envolvidas na grande operação de aprender e ensinar línguas.

Na seção 2.2.4, a seguir, apresente um breve histórico de livros didáticos de português para estrangeiros produzidos no Brasil e em outros países. $\mathrm{Na}$ seção subsequente, foco especificamente o percurso de elaboração de livros de PLE argentinos. 


\subsubsection{Os MDs de PLE produzidos no Brasil e em outros países- Breve histórico}

Segundo Gomes de Mattos (1989) o Ensino de Português como Língua Estrangeira começou a ter desenvolvimento a partir de meados da década de 60. O primeiro LD de PLE que se conhece é o O Spoken Brasilian Portuguese, elaborado e lançado nos Estados Unidos nos anos 50 pelo "American Council of Learned of Societes" para as forças armadas dos EEUU, da autoria do ítalo-americano, Vicenzo Cioffardi, quem havia aprendido português sendo Adido Naval no Rio de Janeiro e recebido alguma orientação linguística nos Estados Unidos. Tratava-se de um material para o ensino de caráter estruturalista, teoria linguística em vigor naquela época.

No Brasil, durante os anos 50, Marchandt publicou o seu "Português para Estrangeiros" também concebido com base na abordagem estruturalista. Na Alemanha, a editora Hueber publicou o Weltsprache Portugiesisch, de Lind. Há nesses livros, textos não autênticos que abordam tanto a linguagem oral cotidiana como alguns temas da cultura brasileira. Em ambos há poucas explicações gramaticais, sempre feitas em inglês ou alemão.

Nas décadas de 60 e 70, aparecem "Português I", da Berlitz, "Português Contemporâneo I", e "Português: conversação e gramática". O primeiro tinha como foco apenas ensinar a falar e a entender; já os outros dois, mesmo que mantivessem a base estruturalista do primeiro acrescentavam exercícios de mecanização da língua tendência áudio-lingual.

O Modern Portuguese surge também na década de 70 junto com Português para estrangeiros 1 e 2, da Yázigi. Ambos, preocupam-se com a apresentação de um português mais informal, o qual é mais acentuado no segundo livro, uma abordagem sociolinguística do português. A partir dos anos 80, apareceram volumes de ensino preocupados com as necessidades específicas dos falantes de língua espanhola: "Português para falantes de Espanhol”, "Tudo bem - Português para a nova geração" e “Avenida Brasil: curso básico de português para estrangeiros", publicados por editoras brasileiras. Todos apresentam o português padrão em textos e áudios com exercícios mecânicos de estruturas gramaticais ou itens lexicais.

Dez anos depois, na década de 90, publicou-se no México Saravá, e no Paraguai Português para crianças de fala hispânica. Esses LDs tinham igualmente a preocupação com as necessidades específicas do público hispanofalante. No Brasil, a 
partir dos anos 90, a produção de LDs para o ensino de PLE aumentou substancialmente e os públicos se diversificaram. Surgiram "Um português bem brasileiro", "Conhecendo o Brasil - curso de português para falantes de espanhol", para crianças "Português para estrangeiros infanto-juvenil", para adolescentes "Português para jovens de fala hispânica", "Sempre amigos: fala Brasil para jovens", para funcionários de empresas: "Panorama Brasil: ensino do português no mundo dos negócios", e para candidatos ao exame Celpe-Bras "Estação Brasil: português para estrangeiros" (DINIZ, 2008). Essas produções e outras são detalhadas nas tabelas a seguir:

Tabela 2- LDs para o ensino de Português LE / L2 produzidos no Brasil e em outros

\begin{tabular}{|c|c|c|c|c|}
\hline Ano & Título & Autores & Editora & Público alvo/nível \\
\hline 1954 & Português para estrangeiros & $\begin{array}{l}\text { MARCHANT, } \\
\text { Mercedes }\end{array}$ & $\begin{array}{l}\text { Porto Alegre: } \\
\text { Age }\end{array}$ & $\begin{array}{l}\text { "Estrangeiros de qualquer } \\
\text { nacionalidade" }\end{array}$ \\
\hline 1969 & $\begin{array}{l}\text { Português conversação e } \\
\text { gramática }\end{array}$ & $\begin{array}{l}\text { MAGRO, } \\
\text { Haydee S. , } \\
\text { PAULA, Paulo } \\
\text { de }\end{array}$ & $\begin{array}{c}\text { São Paulo, } \\
\text { Pioneira/Brazilian } \\
\text { American } \\
\text { Cultural } \\
\text { Institute }\end{array}$ & Básico e intermediário \\
\hline $\begin{array}{l}1976 \\
\left(2^{\circ}\right. \\
\text { Ed. })\end{array}$ & $\begin{array}{l}\text { Português Básico para } \\
\text { estrangeiros }\end{array}$ & $\begin{array}{l}\text { MONTEIRO, } \\
\text { Sylvio }\end{array}$ & São Paulo: Ibrasa & Nível Básico \\
\hline 1981 & $\begin{array}{l}\text { Falando, lendo, escrevendo } \\
\text { português: um curso de } \\
\text { português para estrangeiros }\end{array}$ & $\begin{array}{l}\text { LIMA, Emma E. } \\
\text { O. F., IUNES, } \\
\text { Samira A. }\end{array}$ & São Paulo: EPU & $\begin{array}{l}\text { "Adultos e adolescentes a } \\
\text { partir dos } 13 \text { anos, de } \\
\text { qualquer nacionalidade. } \\
\text { Leva o aluno totalmente } \\
\text { até o nível intermediário" }\end{array}$ \\
\hline 1984 & $\begin{array}{c}\text { Tudo bem? Português para a } \\
\text { nova geração }\end{array}$ & $\begin{array}{c}\text { PONCE, Maria } \\
\text { H. O., BURIM, } \\
\text { Silvia Florissi }\end{array}$ & São Paulo: SBS & $\begin{array}{l}\text { "Voltado às necessidades } \\
\text { do Publico jovem" }\end{array}$ \\
\hline 1986 & $\begin{array}{c}\text { Avenida Brasil: curso básico de } \\
\text { português para estrangeiros }\end{array}$ & $\begin{array}{l}\text { LIMA, Emma E. } \\
\text { O. F., } \\
\text { ROHRMANN, } \\
\text { Lutz, } \\
\text { ISHIHARA, } \\
\text { Tokiko, } \\
\text { BERGWAILER, } \\
\text { Cristian G. , } \\
\text { IUNES, Samira } \\
\text { A. }\end{array}$ & São Paulo: EPU & $\begin{array}{c}\text { "Destina-se a estrangeiros } \\
\text { de qualquer } \\
\text { nacionalidade, } \\
\text { adolescentes e adultos } \\
\text { que queiram aprender } \\
\text { Português para poder } \\
\text { comunicar-se com } \\
\text { brasileiros e participar de } \\
\text { sua vida cotidiana" }\end{array}$ \\
\hline 1989 & Fala Brasil & \begin{tabular}{|c|} 
COUDRY, \\
Pierre, \\
FONTÃO DO \\
PATROCÍNIO, \\
Elizabeth
\end{tabular} & Campinas: Pontes & $\begin{array}{c}\text { "Falantes de qualquer } \\
\text { idioma" }\end{array}$ \\
\hline
\end{tabular}




\begin{tabular}{|c|c|c|c|c|}
\hline 1990 & Português como segunda língua & $\begin{array}{l}\text { ALMEIDA, } \\
\text { Marilú M., } \\
\text { GUIMARÃES, } \\
\text { Lúcia A. C. } \\
\text { Loureiro }\end{array}$ & $\begin{array}{l}\text { Rio de Janeiro: } \\
\text { Ao Livro Técnico }\end{array}$ & $\begin{array}{c}\text { "O livro tem como } \\
\text { objetivo suprir as } \\
\text { necessidades encontradas } \\
\text { no estudo do Português. } \\
\text { Destina-se a alunos que já } \\
\text { tenham noções da língua" }\end{array}$ \\
\hline 1990 & $\begin{array}{l}\text { Português via Brasil: um curso } \\
\text { avançado para estrangeiros }\end{array}$ & $\begin{array}{l}\text { LIMA, Emma E. } \\
\text { O. F., IUNES, } \\
\text { Samira A. }\end{array}$ & São Paulo: EPU & $\begin{array}{l}\text { "Pessoas que tenham } \\
\text { terminado o curso básico } \\
\text { de Português como língua } \\
\text { estrangeira e desejam } \\
\text { prosseguir seus estudos } \\
\text { em nível intermediário e } \\
\text { avançado" }\end{array}$ \\
\hline 1991 & $\begin{array}{c}\text { Aprendendo português do } \\
\text { Brasil: um curso para } \\
\text { estrangeiros }\end{array}$ & $\begin{array}{c}\text { LAROCA, } \\
\text { Maria N. C., } \\
\text { BARA, Nadime, } \\
\text { PEREIRA, } \\
\text { Sonia M. da C. }\end{array}$ & Campinas: Pontes & $\begin{array}{l}\text { "O livro tem como } \\
\text { objetivo dar condições ao } \\
\text { aluno estrangeiro de } \\
\text { dominar, em pouco } \\
\text { tempo, as estruturas } \\
\text { fundamentais da língua } \\
\text { portuguesa, nas } \\
\text { modalidades orais e } \\
\text { escritas" }\end{array}$ \\
\hline 1994 & $\begin{array}{l}\text { Português para estrangeiros: } \\
\text { infanto-juvenil }\end{array}$ & $\begin{array}{l}\text { MARCHANT, } \\
\text { Mercedes }\end{array}$ & $\begin{array}{l}\text { Porto Alegre: } \\
\text { Age }\end{array}$ & $\begin{array}{c}\text { Nível básico e avançado } \\
\text { “Crianças e adolescentes } \\
\text { cuja língua materna é o } \\
\text { espanhol }\end{array}$ \\
\hline 1999 & $\begin{array}{l}\text { Bem-vindo: a língua portuguesa } \\
\text { no mundo da comunicação }\end{array}$ & $\begin{array}{l}\text { PONCE, Maria } \\
\text { H. O., BURIM, } \\
\text { Silvia R. B. A., } \\
\text { FLORISSI, } \\
\text { Susana }\end{array}$ & São Paulo: SBS & $\begin{array}{l}\text { "Público de jovens e } \\
\text { adultos de qualquer } \\
\text { nacionalidade que queira } \\
\text { aprender português, com } \\
\text { sotaque brasileiro, como } \\
\text { língua estrangeira" }\end{array}$ \\
\hline 2000 & $\begin{array}{l}\text { Sempre Amigos: Fala Brasil } \\
\text { para jovens }\end{array}$ & $\begin{array}{l}\text { FONTÃO DO } \\
\text { PATROCÍNIO, } \\
\text { Elizabeth }\end{array}$ & Campinas: Pontes & $\begin{array}{c}\text { "Público jovem" o último } \\
\text { de seis módulos do livro é } \\
\text { dedicado } \\
\text { especificamente, a } \\
\text { falantes de espanhol }\end{array}$ \\
\hline 2001 & $\begin{array}{l}\text { Interagindo em português: } \\
\text { textos e visões do Brasil }\end{array}$ & $\begin{array}{l}\text { HENRIQUES, } \\
\text { Eunice R., } \\
\text { GRANNIER, } \\
\text { Danielle M. }\end{array}$ & $\begin{array}{l}\text { Brasília: } \\
\text { Thesaurus }\end{array}$ & $\begin{array}{c}\text { Iniciante( Vol. I) } \\
\text { Intermediário (Vol. II) } \\
\text { Avançado (Vol. III no } \\
\text { prelo) }\end{array}$ \\
\hline 2002 & $\begin{array}{c}\text { Passagens - português do Brasil } \\
\text { para estrangeiros }\end{array}$ & CELLI, Rosine & Campinas: Pontes & "Adolescentes e adultos" \\
\hline 2003 & Diálogo Brasil & $\begin{array}{l}\text { LIMA, Emma E. } \\
\text { O. F., IUNES, } \\
\text { Samira A. } \\
\text { LEITE, Marina } \\
\text { R. }\end{array}$ & São Paulo: EPU & $\begin{array}{l}\text { "Destinado a um público } \\
\text { adulto, a profissionais de } \\
\text { todas as áreas que } \\
\text { necessitem um } \\
\text { aprendizado seguro e } \\
\text { relativamente rápido, } \\
\text { aplicando-se também a } \\
\text { um público jovem" } \\
\text { "Abrange o ensino da } \\
\text { língua desde suas } \\
\text { primeiras noções, }\end{array}$ \\
\hline
\end{tabular}




\begin{tabular}{|c|c|c|c|c|}
\hline & & & & $\begin{array}{l}\text { chegando ao final do } \\
\text { nível intermediário" }\end{array}$ \\
\hline 2005 & $\begin{array}{c}\text { Estação Brasil: português para } \\
\text { estrangeiros }\end{array}$ & $\begin{array}{l}\text { BIZON, AnaC., } \\
\text { FONTÃO DO } \\
\text { PATROCÍNIO, } \\
\text { Elizabeth }\end{array}$ & $\begin{array}{l}\text { Campinas: } \\
\text { Átomo }\end{array}$ & \begin{tabular}{|} 
"Alunos aprendizes que já \\
alcançaram uma \\
proficiência média em \\
PLE: alunos que já \\
desejam se preparar para \\
o exame de proficiência \\
CELPE-BRAS"
\end{tabular} \\
\hline 2006 & $\begin{array}{l}\text { Panorama Brasil: ensino de } \\
\text { português no mundo dos } \\
\text { negócios }\end{array}$ & $\begin{array}{l}\text { PONCE, } \\
\text { Harumi de, } \\
\text { BURIM, Silvia, } \\
\text { FLORISSI, } \\
\text { Susana }\end{array}$ & $\begin{array}{l}\text { São Paulo: } \\
\text { Galpão }\end{array}$ & $\begin{array}{c}\text { "Livro voltado para o } \\
\text { mundo dos negócios. } \\
\text { Ideal para alunos de nível } \\
\text { intermediário e avançado, } \\
\text { é uma importante } \\
\text { ferramenta para } \\
\text { educadores que trabalham } \\
\text { com diretores executivos } \\
\text { e demais funcionários de } \\
\text { empresas que vem } \\
\text { trabalhar no Brasil" }\end{array}$ \\
\hline 2008 & $\begin{array}{c}\text { Terra Brasil: curso de língua e } \\
\text { cultura }\end{array}$ & $\begin{array}{c}\text { PÉRET } \\
\text { DELL'ISOLA, } \\
\text { Regina L., } \\
\text { APPARECIDA } \\
\text { DE ALMEIDA, } \\
\text { Maria José }\end{array}$ & $\begin{array}{l}\text { Minas Gerais: Ed. } \\
\text { UFMG }\end{array}$ & $\begin{array}{c}\text { "Este livro traz exercícios } \\
\text { em contextos } \\
\text { comunicativos plausíveis, } \\
\text { orais e escritos, com foco } \\
\text { na compreensão dos } \\
\text { aspectos culturais do } \\
\text { Brasil; segue os } \\
\text { princípios do CELPE- } \\
\text { Bras" }\end{array}$ \\
\hline 2008 & $\begin{array}{c}\text { Novo Avenida Brasil: curso } \\
\text { básico de português para } \\
\text { estrangeiros }\end{array}$ & $\begin{array}{l}\text { BERGWEILER, } \\
\text { Cristián G.; } \\
\text { EBERLEIN O. } \\
\text { F. LIMA, } \\
\text { Emma; } \\
\text { ROHRMANN, } \\
\text { Lutz; } \\
\text { LUNES. Samira } \\
\text { A.; } \\
\text { ISHIHARA, } \\
\text { Tokiko. }\end{array}$ & Saõ Paulo: EPU & $\begin{array}{c}\text { "Destina-se a } \\
\text { principiantes adolescentes } \\
\text { e adultos, de qualquer } \\
\text { nacionalidade, que } \\
\text { queiram aprender o } \\
\text { Português como é falado } \\
\text { no Brasil. Pode ser usado } \\
\text { com grupos ou em aulas } \\
\text { individuais." }\end{array}$ \\
\hline
\end{tabular}

Fonte: DINIZ 2008, com acréscimos da autora.

\subsubsection{Os LDs de PLE elaborados na Argentina para hispanofalantes}

Na década de 80, a Linguística Aplicada já se preocupava com a especificidade do ensino de PLE para falantes de espanhol. Lombello et al (1983) afirmava que [...] um curso de português para falantes de espanhol deve realmente ser diferente dos cursos para outros estrangeiros. Os principais motivos para essas diferenças serem discutidas, nas palavras de Simões et al, (2004, p. 28) são 
1. O alto grau de compreensão de L2 mesmo no início do aprendizado 2. A fossilização prematura de uma interlíngua por causa do seu alto poder comunicativo 3. O processo de aprendizado muito mais rápido quando comparado ao daqueles falantes de outras línguas 4. A necessidade de desenvolver a consciência metalinguística dos estudantes em relação às diferenças entre a sua L1 e a L2.

As pesquisas nessa área se concentram no risco de fossilização do "portunhol" como interlíngua, (ALMEIDA FILHO, 2004; SANTOS, 1999; FERREIRA, 1995, 1997, 2002). Algumas analisam as dificuldades específicas apresentadas pelos aprendizes na aquisição, produto de diferenças entre os sistemas linguísticos do português e do espanhol (LOMBELLO, 1983), outras tratam sobre o fenômeno do português como L3 para hispanofalantes residentes nos Estados Unidos (SIMÕES, CARVALHO \& WIEDEMAN, 2004), e também há investigações sobre o desempenho do público de fala hispânica no exame CELPE-BRAS (SANTOS, 1999; CUNHA, 1999; SCARAMUCCI, 1999).

Santos (1999) afirma a necessidade do ensino de português para hispanofalantes ser diferenciado do português para falantes de outras línguas

Devido à grande semelhança entre as duas línguas, o ensino de português para falantes de espanhol possui características próprias que o distingue daquele voltado para falantes de outros idiomas. Se por um lado essa semelhança facilita o entendimento do português logo aos primeiros contatos, por outro impede, na maioria das vezes, que o falante de espanhol se comunique sem as constantes interferências da sua língua nativa.

No entanto, para Almeida Filho (1995, p. 18-19) isso não quer dizer que o ensino de PLE ao público hispânico precise de uma metodologia específica, mas de algumas especificidades como: o uso da focalização consciente e atenta sobre aspectos contrastivos salientes e proximais enganosos entre as duas línguas, evitar o passo-apasso comum do ensino lento e gradual da forma e das estruturas descritas do Português, usar progressões de experiências baseadas no ensino temático ou interdisciplinar do ensino comunicativo, incentivar o aluno à crítica de sua própria produção mostrando os pontos que não sabe usar ainda na nova língua. Esses são alguns 
procedimentos que o autor considera relevantes para "evitar ou amenizar" as dificuldades do processo de ensino e aprendizagem.

Os livros didáticos que se declaram específicos para o ensino de português a falantes de espanhol trazem, em sua maioria, uma concepção de ensino de língua como sistema. Por tanto, o Português é apresentado na versão não recomendada por Almeida Filho, o passo-a-passo lento baseado em conteúdos linguísticos e contraste limitado a itens gramaticais das duas línguas. Cabe aqui uma reflexão: os materiais didáticos devem necessariamente codificar as especificidades necessárias ao ensino de PLE aos falantes de espanhol? Se sim, quais? É uma pergunta para ser explorada em outro trabalho de pesquisa.

$\mathrm{Na}$ Argentina, o "Centro Cultural Brasil Argentina" (CCBA), foi a primeira instituição a colocar no mercado, em 1997, um livro didático de PLE, "Um português bem Brasileiro" (Volumes 1 a 4). Esse material foi produzido para levar à frente a tarefa essencial do Centro, o ensino da língua e divulgação da cultura do Brasil no contexto do SEM (Setor Educacional do MERCOSUL). Na sua apresentação, o Ministro de Educação e Desporto do Brasil diz que o livro baseia-se numa abordagem comunicativa. Não obstante, todos os volumes estão organizados com base no conceito de língua como sistema de estruturas. Em 2000, a FUNCEB lançou outro livro, "Conhecendo o Brasil" Nível Básico para hispanofalantes. Os dois materiais didáticos produzidos pelo CCBA não estão mais à venda e na visita que fiz ao Centro em julho de 2012 me informaram que alguns professores estão trabalhando numa nova coleção.

Cinco anos depois, duas autoras independentes, Santinha André e Maria Marta Santa Maria, lançaram em dois volumes o livro "Português Dinâmico". As autoras explicitam na introdução do livro que o mesmo "tem como objetivo levar ao aluno o conhecimento da língua portuguesa de uma forma clara onde a gramática vai de mãos dadas com os temas atuais e culturais do Brasil”. Na sua organização, os dois volumes apresentam claros traços da abordagem gramatical comunicativizada, pois as unidades estão organizadas em torno de funções e situações de comunicação com exercícios sistemáticos dos tópicos gramaticais e de vocabulário, predominantes nessas situações.

Por último, em 2010, "Brasil Intercultural” foi produzido pela "Casa do Brasil em Buenos Aires" e "Horizontes: Rumo à proficiência em língua portuguesa" pelas autoras independentes Adriana Almeida e Cibele Barbosa. Em ambos os livros, suas autoras declaram ter elaborado os materiais a partir dos princípios da "abordagem 
intercultural". Atualmente, a Casa do Brasil trabalha na revisão e nova edição de seu material, no entanto o livro Horizontes não é mais vendido nas livrarias do país. Esses dois são os títulos que selecionei como objeto de estudo desta pesquisa, e por isso, dados mais específicos sobre eles serão encontrados no Capítulo IV - Análise de dados.

A seguir, uma tabela resumo dos materiais didáticos para o ensino de PLE elaborados na Argentina:

Tabela 3 - Livros didáticos de PLE de produção argentina

\begin{tabular}{|c|c|c|c|c|}
\hline Ano & Título & Autores & Editora & Público alvo/nível \\
\hline 1997 & Um português bem brasileiro & \multirow{2}{*}{$\begin{array}{l}\text { FUNCEB } \\
\text { (Fundação } \\
\text { Centro de } \\
\text { Estudos } \\
\text { Brasileiros) }\end{array}$} & $\begin{array}{l}\text { Buenos } \\
\text { Aires, } \\
\text { Loyola }\end{array}$ & $\begin{array}{l}\text { Níveis } 1 \text { a } 4 \text { para } \\
\text { hispanofalantes }\end{array}$ \\
\hline 2000 & $\begin{array}{l}\text { Conhecendo o Brasil - Curso de } \\
\text { português para falantes de espanhol }\end{array}$ & & $\begin{array}{c}\text { Buenos } \\
\text { Aires, } \\
\text { Akian } \\
\text { Gráfica } \\
\text { Editora S.A }\end{array}$ & $\begin{array}{l}\text { Nível básico para } \\
\text { hispanofalantes }\end{array}$ \\
\hline 2005 & $\begin{array}{l}\text { Português Dinâmico: curso de } \\
\text { português para hispanofalantes } \\
\text { (Níveis } 1 \text { e 2) }\end{array}$ & $\begin{array}{c}\text { ANDRÉ, } \\
\text { Santinha, } \\
\text { SANTA } \\
\text { MARIA, } \\
\text { Maria Marta }\end{array}$ & $\begin{array}{l}\text { Buenos } \\
\text { Aires, Ed. } \\
\text { Ediciones } \\
\text { de Autor }\end{array}$ & $\begin{array}{l}\text { Nível básico e } \\
\text { intermediário para } \\
\text { hispanofalantes }\end{array}$ \\
\hline 2010 & $\begin{array}{c}\text { Coleção "Brasil Intercultural" - } \\
\text { língua e cultura brasileira para } \\
\text { estrangeiras }\end{array}$ & Casa do Brasil & $\begin{array}{l}\text { Buenos } \\
\text { Aires, Ed. } \\
\text { Casa do } \\
\text { Brasil. }\end{array}$ & $\begin{array}{c}\text { Coleção de } 3 \text { volumes } \\
\text { organizados em diferentes } \\
\text { níveis para falantes de } \\
\text { outras línguas com enfoque } \\
\text { específico para } \\
\text { hispanofalantes }\end{array}$ \\
\hline 2010 & $\begin{array}{c}\text { Horizontes - Rumo a Proficiência } \\
\text { em Língua Portuguesa }\end{array}$ & $\begin{array}{l}\text { ALMEIDA, } \\
\text { Adriana, } \\
\text { BARBOSA, } \\
\text { Cibele }\end{array}$ & $\begin{array}{l}\text { Buenos } \\
\text { Aires, Ed. } \\
\text { LiBreAr }\end{array}$ & $\begin{array}{l}\text { Um volume com CD para } \\
\text { alunos que desejam revisar, } \\
\text { aperfeiçoar e consolidar os } \\
\text { conhecimentos linguísticos } \\
\text { e culturais adquiridos em } \\
\text { cursos de PLE. }\end{array}$ \\
\hline
\end{tabular}

Fonte: Elaborado pela autora 
Figura 3 - Capa do Livro: Um português bem brasileiro - Ed. FUNCEB - Volume 3

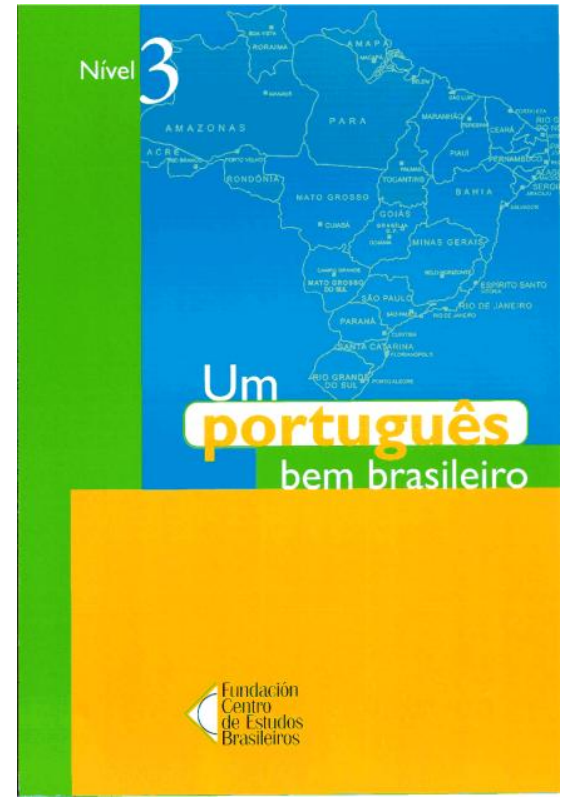

Fonte: Arquivo pessoal

Figura 4 - Capa dos livros "Português Dinâmico" Volume 1 e 2 - Curso de Português para hispanofalantes Ed. Ediciones de Autor
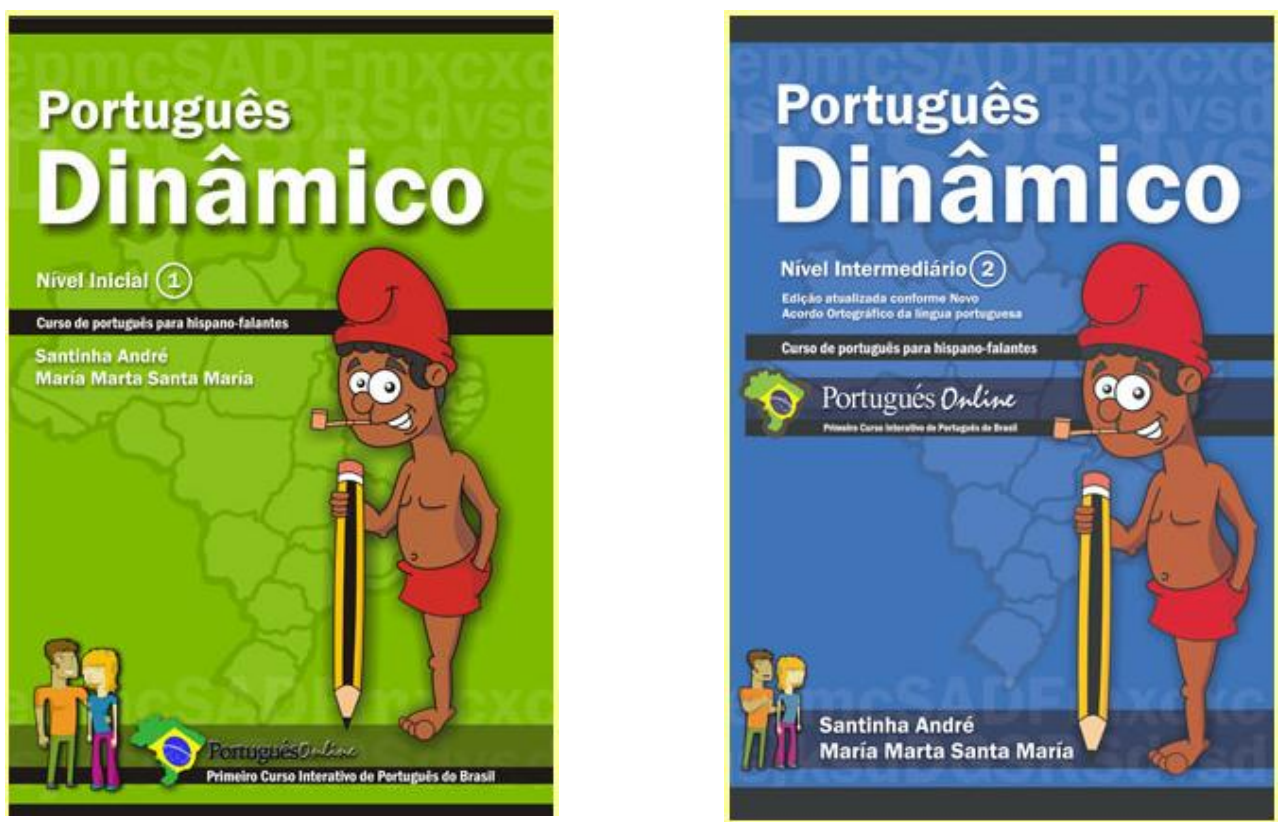

Fonte: Disponível em www.portuguesdinamico.com/pd2.html 


\subsection{A ABORDAGEM DE MATERIAIS DIDÁTICOS}

Ao longo deste capítulo faço alusão ao conceito de abordagem no conjunto de ações que compõem a grande operação de ensinar e aprender línguas. Como explicitei na introdução e venho reforçando no decorrer da dissertação, minha atenção recai sobre a abordagem dos materiais didáticos de PLE produzidos na Argentina para o público de fala hispânica. Por isso, nesta seção quero abordar os seguintes temas com Teoria e alguns pressupostos: o conceito de abordagem e como reconhecer uma abordagem num MD.

\subsubsection{Abordagem, método e técnica}

Em 1963, o linguista aplicado Edward M. Anthony, trouxe a discussão dos conceitos de abordagem, método e técnica para sistematizar e diferenciar o uso desses três termos no ensino de línguas. Dezenove anos mais tarde, em 1982, Richards \& Rodgers também se propuseram a discutir esses termos mas com o intuito de desenvolver um modelo que descrevesse e permitisse comparar métodos (ALMEIDA FILHO, 1997, p. 19). Mais recentemente, em 1993, o professor e linguista aplicado José Carlos Paes de Almeida Filho, com maior proximidade quanto à relação hierárquica da tríade conceitual de Anthony, propôs esclarecer a [...] composição e funcionamento da operação complexa de ensinar línguas num modelo articulado nas concepções fundadoras da abordagem, do método e das técnicas [...] (ibid). Em 2006, Kumaravadivelu, propôs um modelo binário com base nas dimensões da tríade de Antonhy (1963) e Richards \& Rodgers (1982).

Para Anthony (1963), abordagem é um "conjunto axiomático de pressupostos correlacionados ao que é língua e o que é ensinar e aprender uma língua”, método faz referência ao "plano global", às maneiras pelas quais tais conceitos e pressupostos são “apresentados ordenadamente em material de linguagem”, de ensino e aprendizagem (procedimentos), e técnica é o que efetivamente acontece e se implementa em sala de aula. As técnicas evidenciam um método que é consistente com uma abordagem. Por exemplo, para a "Abordagem Gramatical", ensinar e aprender uma língua significa ensinar e aprender o sistema dela, a sua gramática. Um dos métodos mais usados para esses pressupostos de ensino é a "prática de padrões" que leva ao aprendizado/memorização das regras gramaticais da língua para juntar as palavras em 
frases para uso posterior em situações. As técnicas usadas nesse método são os exercícios para preencher lacunas, a memorização de regras e listas de vocabulário, a repetição de elementos, a transformação de frases do singular para o plural, do presente para o passado.

Para Richards \& Rodgers (1982) o método é o termo líder e dele se deslocam a abordagem, o planejamento e os procedimentos, os três no mesmo nível hierárquico. $\mathrm{Na}$ visão dos dois autores, abordagem tem o mesmo significado que para Anthony, embora o conceito dominante seja o do método. O planejamento refere-se aos objetivos do método, às decisões sobre como o conteúdo é selecionado e organizado, aos tipos de atividades de ensino, aos papéis dos professores, dos aprendizes e do material didático. Em outras palavras, o aspecto central do planejamento é aplicar uma abordagem ao desenvolvimento do método. Finalmente, os procedimentos são as práticas e comportamentos efetivos, adotados pelo professor em situações momentâneas de ensino em sala de aula, ou seja, os procedimentos são as ações concretas que efetivamente exprimem a abordagem e o design de um método. Essa não me parece uma solução efetiva desde que planejamento, abordagem e procedimentos estão na mesmo nível hierárquico e o método domina a operação de ensinar e aprender uma LE.

Kumaravadivelu (2006, p. 86 -87) afirma que no modelo de Richards \& Rodgers (1982), o termo método funciona como um "guarda-chuva" acolhendo a relação mais abrangente entre teoria e prática no ensino de línguas. Para Kumaravadivelu (2006, p. 86) esse modelo é mais completo e detalhado do que o de Antonhy (1963). Não obstante, os dois são igualmente redundantes e apresentam sobreposição de conceitos. Ele argumenta que a delimitação entre abordagem e planejamento é confusa porque [...] as definições de base de ambos os termos se relacionam com pressupostos teóricos que na realidade pertencem ao campo da abordagem (KUMARAVADIVELU 2006, p. 87).

Kumaravadivelu (2006, p. 88-89) rejeita os modelos triádicos de Antonhy (1963) e Richards \& Rodgers (1982) e propõe um modelo binário composto por "princípios e procedimentos" a partir da seguinte lógica: 1) a primeira dimensão dos modelos anteriores é a abordagem e refere-se a princípios provenientes da linguística, psicologia, sociologia, antropologia, ciências da informação, análise do discurso, todos campos do saber envolvidos no ensino e aprendizagem de línguas (não lhe ocorre ao autor que esses princípios possam vir da própria LA) 2) a segunda dimensão, método ou planejamento, pode ser interpretada como parte da primeira já que abrangem princípios 
de produção de materiais, elaboração e avaliação de currículos e 3) as técnicas ou procedimentos remetem às estratégias usadas durante a aula. Assim, para o autor “princípios” são (KUMARAVADIVELU, 2006, p. 88)

\begin{abstract}
um conjunto de percepções derivadas da linguística teórica e aplicada, da psicologia cognitiva, das ciências da informação e de outras disciplinas afins que possam fornecer subsídios teóricos para o estudo de aprendizagem, planejamento e ensino de línguas. O termo, portanto, engloba não apenas os pressupostos teóricos que regem a aprendizagem e o ensino de línguas mas também os que regem a elaboração de currículos, a produção de materiais e medidas de avaliação. ${ }^{1}$
\end{abstract}

Procedimentos poderiam ser definidos como [...] um conjunto de estratégias de ensino adotadas e adaptadas pelo professor para atingir os objetivos de ensino e aprendizagem, estabelecidos e não estabelecidos, a curto - e longo - prazo na sala de aula $^{2}$. Trata-se da mesma definição já dada por Richards \& Rodgers (1982). Parece-me que o modelo binário de Kumaravadivelu também se dilui na sobreposição de conceitos e não é tão representativo da operação total de aprender e ensinar uma língua.

Por outro lado, para Almeida Filho (1997, p. 20) os arcabouços de Anthony e de Richards \& Rodgers [...] são limitados quanto às relações explicitadas entre os elementos constituidores. Esse autor (ibid) propõe um modelo que representa como se compõe a grande e complexa operação de ensino de línguas de maneira mais articulada, com base no conceito de abordagem, método e técnica articulados numa hierarquia comandada pela abordagem (ALMEIDA FILHO, 1997, p 17-25, grifo meu)

\begin{abstract}
Abordagem: Força que orienta, e portanto, caracteriza em essência, todo um processo específico de ensino de línguas. Essa força advém das competências implícita (básica), teórica, aplicada e (meta) profissional do professor ou de quaisquer outros agentes ativos de ensino tais como autores de LD, planejadores de cursos, produtores de instrumentos de avaliação, pais, tutores, etc. Essas competências trabalham com posicionamentos explícitos no caso das competências aplicada, englobando a subcompetência teórica, e profissional, e com posicionamentos implícitos com intuições, disposições a partir de experiências prévias, cultura
\end{abstract}

\footnotetext{
${ }^{1}$ The term, principles, may be operationally defined as a set of insights derived from theoretical and applied linguistics, cognitive psychology, information sciences, and other allied disciplines that provide theoretical bases for the study of language learning, language planning, and language teaching. The term thus includes not only the theoretical assumptions governing language learning and teaching but also those governing syllabus design, materials production, and evaluation measures.

${ }^{2}[\ldots]$ as a set of teaching strategies adopted/adapted by the teacher in order to accomplish the stated and unstated, short- and long-term goals of language learning and teaching in the classroom.
} 
compartilhada de ensinar da região/escola, etc., no caso da competência implícita. A força da abordagem provém da energia da motivação para ensinar, opera com "matéria prima" de conhecimentos explícitos e implícitos e se desempenha no ensinar em níveis distintos de competências. Os implícitos são teoria formal subjetiva, intuitiva, muitas vezes na forma de crenças culturalmente marcadas pelo inconsciente coletivo. Os explícitos são teoria formalizada, aprendida, (re)construída e citável na forma de pressupostos e princípios estabilizados. Pode resultar contraditória a força da abordagem como resultado de posições teóricas conflitivas das três vertentes de que decorre a teoria: a concepção de linguagem (de língua, linguagem humana, língua estrangeira) a concepção de ensinar línguas, $e$ a concepção de aprender/adquirir língua, os papéis e atitudes de professor e aluno/aprendiz, e a concepção de sala de aula de que se parte para produzir o ensino. A abordagem orienta o processo ou operação global de ensino que se compõe ordenadamente no seu todo das fases do planejamento de cursos, de produção ou adoção via análise dos materiais das experiências realizadas para aprender, e das avaliações de rendimento efetuadas.

Segue um diagrama ilustrativo do conceito de abordagem de ensinar do mesmo autor (ALMEIDA FILHO, 1997, p. 18)

\section{Figura 5 - Diagrama ilustrativo do conceito de abordagem}

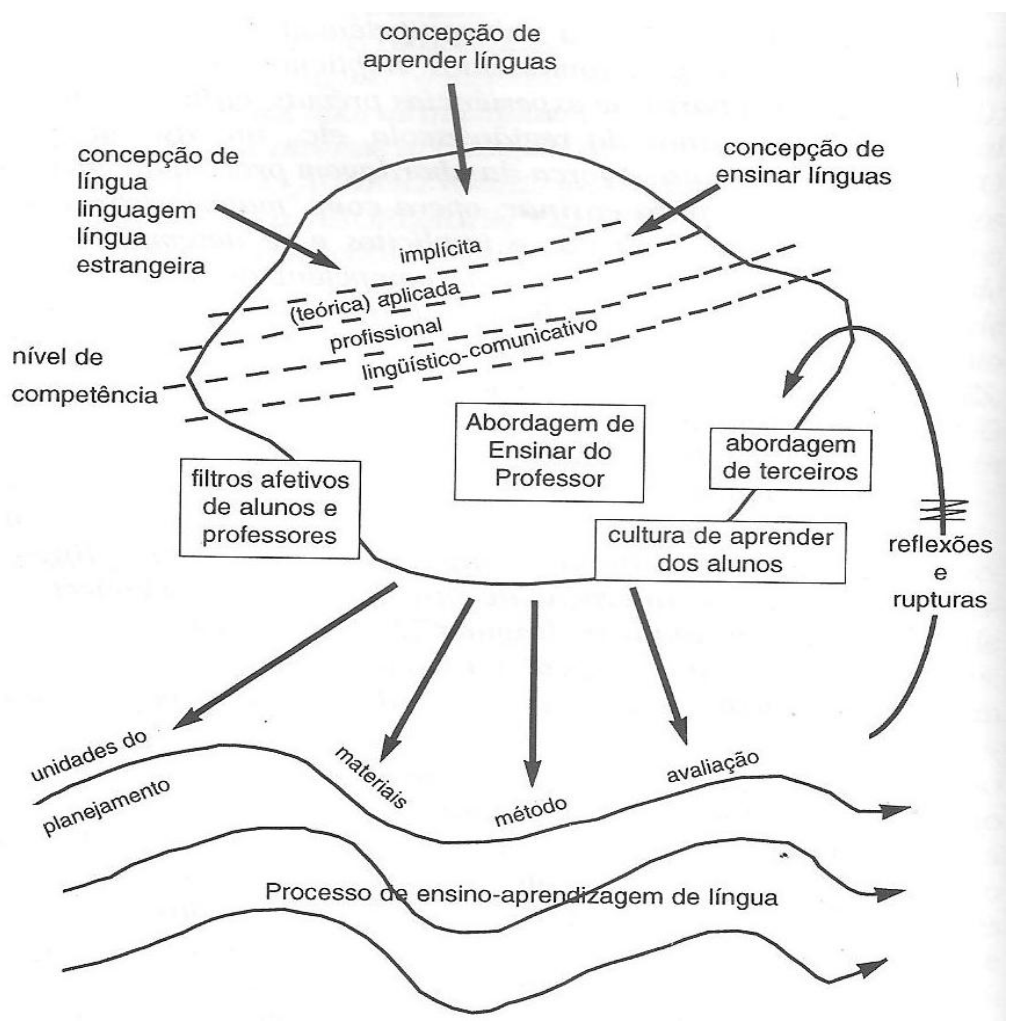

Fonte: ALMEIDA FILHO (1997) 
Na tríade proposta por Almeida Filho (1997), abordagem é o conceito superior. Seguem-na hierarquicamente o método, as técnicas ou procedimentos e os recursos. Segundo o autor, essa hierarquia é usada para demonstrar que o nível de abstração da abordagem desce da máxima abstração e generalidade até o nível mais concreto, o da implementação da abordagem em sala de aula. Ao contrário de Anthony (1963), esse modelo propõe níveis com fases horizontais. No segundo nível de Almeida Filho (1997, p. 20) há quatro fases constituidoras ordenadas, também chamadas de "materialidades" que para o autor

[...] capturam as dimensões do planejamento de unidades previstas, da produção ou adoção de materiais adequados, do método ou experiências de aprender na sala de aula e nas suas extensões, e da avaliação ou rendimento do progresso dos alunos.

Essas fases e níveis estão articuladas pelos efeitos proativo, retroativo, de ruptura gradual e de configuração da abordagem com outras forças incidentes na abordagem de ensinar. Uma dessas outras forças, o interesse focal desta dissertação, é $a$ força maior da abordagem proveniente do material didático. Segue um quadro ilustrativo nas palavras do mesmo autor do seu modelo triádico de níveis e fases:

Tabela 4 - Quadro resumo do modelo triádico de Almeida Filho relacionando abordagem, método e técnica.

\begin{tabular}{|l|l|}
\hline \multicolumn{1}{|c|}{ Categorias e subcategorias } & \multicolumn{1}{|c|}{ Almeida Filho (1993) } \\
\hline Objetivo da proposta & $\begin{array}{l}\text { Um modelo para compreendermos a constituição e funcionamento } \\
\text { da grande operação de ensinar línguas. Permite análise do } \\
\text { processo de ensinar e comparação entre processos }\end{array}$ \\
\hline Níveis & $\begin{array}{l}\text { 1. Hierárquico em três níveis: } \\
\text { 2. Abordagem } \\
\text { 3. Planejamento, materiais, método, avaliação } \\
\text { 4. Técnicas, recursos, instrumentos de ação }\end{array}$ \\
\hline Fases e especificação dos & $\begin{array}{l}\text { Distinção entre quatro fases no segundo nível que constituem a } \\
\text { abordagem: } \\
\text { Planejamento/materiais/método/avaliação }\end{array}$ \\
\hline Dinamismo & $\begin{array}{l}\text { Dinâmico (efeitos marcados: pró-ativo, retroalimentação, } \\
\text { ruptura/configuração com outras forças.) }\end{array}$ \\
\hline Foco & $\begin{array}{l}\text { Processo de ensinar considerando outras forças incidentes, } \\
\text { principalmente o aprender. }\end{array}$ \\
\hline Conceito de abordagem & $\begin{array}{l}\text { Força sintética, potencial, proveniente de um conjunto nem } \\
\text { sempre harmônico de crenças e pressupostos e princípios, que nos } \\
\text { faz atuar da maneira específica em nossas salas de aula. }\end{array}$ \\
\hline
\end{tabular}

Fonte: ALMEIDA FILHO (1997, p. 21) 
Considero que o modelo mais representativo das experiências que tenho observado e vivenciado como docente e que adoto neste trabalho de pesquisa é o de Almeida Filho. Ele explicita o conjunto de ações do ensinar de um professor de línguas em um quadro complexo, dinâmico, dando voz a outras forças, provenientes de outros agentes, envolvidas no processo de aprender e ensinar que não apenas as do professor. A abordagem do material didático, por exemplo, procedente dos seus compositores, autores, é uma dessas outras forças envolvidas no processo de ensino e aprendizagem de línguas. Quando um docente escolhe um determinado material didático para suas aulas e extensões, esse traz uma abordagem implícita que se mistura com a do professor e os outros agentes. Como isso acontece? Como a abordagem do MD age em conjunto com as outras abordagens envolvidas na OGEL? São várias as equações que podem acontecer.

Sem esquecer que o objetivo geral deste trabalho é analisar a abordagem dos MDs de PLE produzidos na Argentina, a seguir trago teoria e pressupostos de "Análise e constituição da Abordagem" para maior familiarização com esse tipo de estudo e com o material didático de LE como objeto de pesquisa. Afinal, é necessário entender quais são os indicadores constituintes da abordagem de um MD para poder reconhecê-la a partir da análise, para, dessa maneira, estudar como ela particularmente age em conjunto com as outras forças potenciais envolvidas na grande operação de ensinar uma nova língua.

\subsubsection{A constituição e análise da Abordagem}

Uma abordagem pode ser compreendida como uma filosofia de trabalho composta pelas concepções de língua, linguagem, língua estrangeira (ALMEIDA FILHO, 1997, p. 22). Concebida como a força motriz das materialidades de ensinar e aprender uma LE da OGEL, [...] orienta, dá consistência e rumo ao trabalho do professor (ibid.) Segundo o mesmo autor, as evidências da abordagem do professor podem ser encontradas nas pistas de ação do seu ensinar, nas aulas, por exemplo, e nas suas extensões, no planejamento do curso, no tipo de avaliação dos alunos. Portanto, seguindo esse raciocínio, as evidências da abordagem de um MD, na verdade, a dos seus autores, podem ser encontradas no tipo de insumo, atividades, teoria, organização das unidades, codificados pelos compositores para a obra. Por outro lado, assim como 
Almeida Filho (ibid) diz que é limitada a possibilidade de considerar o que o professor sustenta sobre si e suas aulas como índice confiável da sua abordagem, pressuponho limitado declarar qual é a abordagem de um MD por meio do que seus autores dizem da obra em si.

Dessa maneira, entendo que para reconhecer a abordagem de um material didático devemos ter claras quais são as pistas que vamos rastrear para identificar os conceitos de língua, linguagem e língua estrangeira do mesmo. Segue um breve quadro de possíveis indicadores (categorias), para com eles se reconhecer a abordagem de um MD, a ser desenvolvido e fundamentado com teoria de Almeida Filho (1997, vide p. 23), Ellis (1996), Skehan (1996), Prabhu (1987), Litllewood (1981), Barbirato (1999), entre outros, e com a própria análise dos dados no Capítulo 3, Análise de Registros, deste trabalho de pesquisa.. Como não encontrei literatura específica que diretamente determinasse esses indicadores (categorias), com base em fundamentos e princípios teóricos da abordagem comunicativa e gramatical (resenhados nas próximas seções e ampliados no Capítulo 3) dos autores supracitados cheguei à conclusão de que as categorias que permitirão elucidar a abordagem dos MDs argentinos são:

Tabela 5 - Indicadores (categorias para reconhecimentos) da abordagem de um material didático de LE

\begin{tabular}{|c|l|}
\hline Unidades & $\begin{array}{l}\text { Conjunto de atividades, temas, insumo, exercícios organizado em torno de temas de } \\
\text { gramática, situações de comunicação, temas de outras disciplinas, entre outros. }\end{array}$ \\
\hline Atividades & $\begin{array}{l}\text { Unidade de ação no método de ensino e aprendizagem de línguas, realizada com o } \\
\text { intuito de praticar ou usar uma língua-alvo em sala, ou outros lugares. No ensino de } \\
\text { línguas, essas ações denominadas atividades se destinam a fazer compreender o } \\
\text { funcionamento da nova língua ou experienciar o uso efetivo dela visando com isso } \\
\text { o desenvolvimento de uma competência comunicativa na língua-alvo. (GLOSSA, } \\
\text { Glossário de Linguística Aplicada) }\end{array}$ \\
\hline Insumo & $\begin{array}{l}\text { Toda manifestação de linguagem na língua-alvo que pode, eventualmente, se tornar } \\
\text { competência comunicativa na interlíngua. O insumo tem de ser recebido por um } \\
\text { filtro afetivo favorável para que tenha chance de se converter em competência } \\
\text { adquirida. Não deve ainda ser gramaticalmente sequenciado e precisa ser de } \\
\text { interesse ou relevante ao aprendente. O insumo pode ser produzido entre os } \\
\text { participantes ou trazido pronto para a sala de aula. (GLOSSA, Glossário de } \\
\text { Linguística Aplicada) }\end{array}$ \\
\hline
\end{tabular}

Fonte: Elaborado pela autora 
$\mathrm{Na}$ literatura encontrada sobre avaliação de material didático, apenas Almeida Filho et al (1997) se referiu à análise da abordagem com o tratamento dado a ela nesta dissertação. Por exemplo, Sheldon (1988), Ramiro (1996) e Fernandez Lopez (2004) propõem quadros e roteiros com critérios (ver Anexo 1, 2 e 3) para a avaliação e seleção do "melhor", mas nenhum deles envolvendo a abordagem do MD. Dias (2009) também fornece um quadro de critérios fundamentado nos documentos do PNLD (Programa Nacional do Livro Didático) de língua portuguesa para avaliar o melhor livro didático (ver Anexo 11). Diferentemente desses autores, Ellis (1996) traz conceitos de análise de MD mais próximos da análise de abordagem.

Esse autor sugere a "avaliação prévia" de materiais, em termos de adequação aos objetivos de ensino do professor e de aprendizado dos alunos, e "avaliação posterior" (empírica, retrospectiva) ao uso também, para verificar possíveis melhorias ou mudanças. A proposta do autor baseia-se na seleção de uma tarefa (vide o conceito de Prabhu, 1987) do MD para submetê-la a uma microavaliação em termos de objetivos, insumo, condições de trabalho (em pares ou grupos, por exemplo), procedimentos a serem usados pelos aprendizes e resultado esperado (um desenho, um mapa, um relatório). Segundo Ellis (1996, p 41), essa microavaliação incentiva o tipo de reflexão esperada do professor em desenvolvimento (formação continuada). Trata-se de uma maneira de o professor validar suas experiências pré e pós-aula que pode variar de argumentos menos ou mais consistentes para justificar o seu agir profissional.

Para Almeida Filho (1994, p. 41) tratar o MD como objeto de estudo não se trata [...] apenas de uma questão de escolha do melhor (segundo fichas prontas de avaliação com quesitos especificamente elaborados para tal fim [...]. O lado mais promissor para escolher/avaliar um MD, segundo esse autor (ibid), é encarar essa tarefa orientada por critérios próprios, explicitados, e justificáveis com teoria relevante. Esse estudo requer a análise do material em si mesmo e a posterior observação do uso dele em sala de aula. A proposta de análise de abordagem de material didático que aqui trago, vê o MD como objeto de estudo nas suas facetas de produção e/ou seleção orientadas por critérios do próprio professor, baseados em teoria justificável.

Em primeiro lugar, se um professor seleciona um material didático com uma abordagem muito diferente da abordagem de ensinar dele corre dois grandes riscos: 1) não ter tempo para adaptá-lo ou e/ou 2) não contar com a formação adequada para essa tarefa, e o MD passa a ser seguido ao pé da letra conforme foi codificado pelo autor. Os 
dois casos colocam em risco o sucesso do aprendiz na árdua tarefa de se apropriar de uma nova língua. Em segundo lugar, não podemos esquecer que o material didático na mão dos aprendizes é um documento que está dizendo a ele o que é importante fazer para a aprendizagem da nova língua. Em terceiro lugar, a análise de abordagem de um MD pode ajudar a superar a formação precária de um professor que usa o material como a única fonte de insumo e único recurso na construção do processo de ensinar e aprender uma LE. Por último, e como consequência da assertiva anterior, a análise de abordagem do MD permite entender como age a força da abordagem do mesmo no quadro total de forças da OGEL levando em consideração a relação professor-aprendiz mediada pelo MD. A seguir, uma representação, num quadro sinótico descritivo, de todas as forças que atuam no quadro da relação professor-aprendiz com o LD como mediador elaborado por Almeida Filho (1994, p.45):

Figura 6 - Incidência de Forças potenciais no processo de ensino-aprendizagem de línguas mediado pelo MD

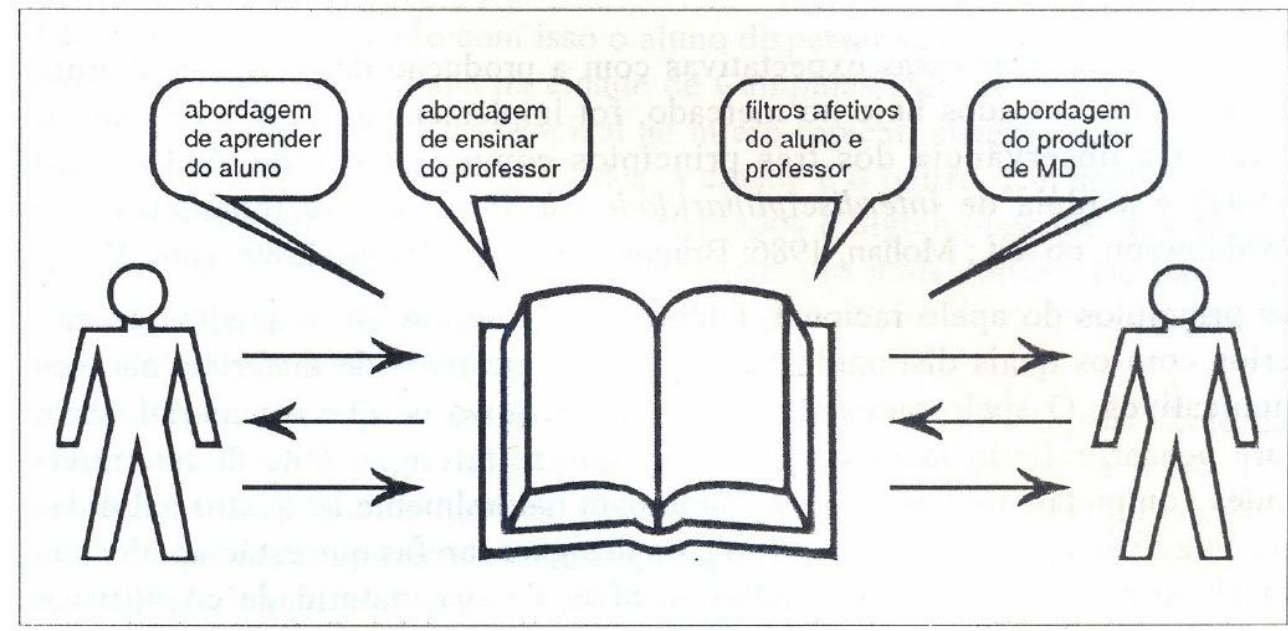

Fonte: ALMEIDA FILHO (1994)

Neste trabalho de pesquisa, a análise de abordagem dos MDs de PLE produzidos na Argentina não envolve o uso dos mesmos em sala de aula. Isso não significa que não considere relevante a observação ou a avaliação posterior ao uso. Trata-se de umas das delimitações da pesquisa relatada nesta dissertação. Escolhi nesta instância focar a análise de abordagem prévia ao uso por tratar-se de uma tarefa inerente à adoção de materiais didáticos (algo que professores de línguas praticamos constantemente), sem 
descartar a ideia de ampliar num futuro estudo o contraste entre a análise prévia e a análise posterior ao emprego em uma situação específica de ensino e aprendizagem.

Fontão (1991, p. 153) defende que trabalhar abordagens de ensinar a partir de uma aula concreta permite evidenciar com maior verossimilhança uma ou outra abordagem predominante. A análise dos dados coletados a partir de entrevistas ou materiais didáticos, segundo a autora (grifo meu), [...] nem sempre revela o enfoque (abordagem) real de um curso [...] (op. cit.). Na visão dessa autora, isso equivale a dizer que um professor pode usar um material didático comunicativo e suas aulas serem da visão gramatical, por exemplo. No entanto, há predominantemente no mercado materiais gramaticais. Assim professores da visão comunicativa muitas vezes trabalham em suas aulas de maneira comunicacional com materiais da visão gramatical, mas essa não é uma situação totalmente desejável para os profissionais do ensino de línguas.

Esse cenário de trabalho exige do professor "capacidades teórica e de uso da LE" (ALMEIDA FILHO, 2012, p. 52) que the permitam introduzir na aula, com frequência, atividades focadas no significado e na comunicação. $O$ professor pode identificar no material didático quais são as unidades salváveis, por exemplo, e segundo o calendário de aulas verificar o que pode ser mais bem aproveitado pelos aprendizes desse ano. Nas escolas de línguas franqueadas muitas vezes o professor fica preso ao livro didático que já traz embutido o planejamento do curso e método a serem utilizados. No caso das escolas públicas a falta de tempo para o planejamento das aulas e seleção ou elaboração de materiais é na maioria das vezes um fator determinante para que o professor fique preso a um livro didático.

Por isso, na pesquisa que aqui proponho pretendo analisar a abordagem dos MDs de PLE recentemente publicados na Argentina. Ainda que seja possível ser um professor comunicativo e dar aula com um material gramatical, essa não é uma situação ideal nas condições em que o ensino de línguas estrangeiras acontece nas escolas públicas brasileiras e argentinas. Por outro lado, como disse anteriormente, materiais didáticos são documentos que ficam na mão de alunos e outros agentes (pais, diretores, colegas) e dizem muito sobre o que o professor e a escola, e todos os agentes envolvidos querem dos aprendizes.

Apresento, a seguir, uma caracterização das duas macroabordagens reconhecidas por Sateles \& Almeida Filho (2010) como predominantes no ensino e aprendizagem de línguas e nos materiais didáticos de hoje (Almeida Filho 1991, 1993, 2012, Ribeiro 
2008): a tradicional abordagem gramatical e a almejada abordagem comunicativa. Cabe salientar que existem tantas abordagens quanto professores, não obstante, aos fins pedagógicos e práticos, as várias visões de ensinar e aprender línguas podem ser concebidas, devido a características comuns, nessas duas macroabordagens, respectivamente.

\subsubsection{Abordagem Gramatical}

Quando se pensa no ensino de segundas línguas, comumente se associa esse processo a iniciativas pedagógicas relacionadas ao ensino formal e institucionalizado da língua, ou seja, com métodos e técnicas mais voltados para a compreensão da línguaalvo de maneira sistêmica e complexa. Essa visão tradicional é chamada de “Abordagem Estrutural/Gramatical”, nela estuda-se a gramática como a grande força motriz do ensino e aprendizagem de uma língua. Isso equivale a conceber que ao conhecermos o funcionamento das regras do sistema de uma dada língua-alvo, podemos fazer o uso correto da mesma, independentemente do contexto. Nessa abordagem, entende-se língua como um sistema de estruturas (forma) que deve ser aprendido, ou seja, ensinar é apenas transmissão de conteúdos em que se reforçam as estruturas e aprender significa armazenar conhecimentos linguísticos sem que haja necessidade de reflexão por parte do aprendiz (FONTÃO, 1991, p.159).

Ao longo dos anos, essa abordagem, por vezes, mostrou-se pouco eficiente no processo de ensino-aprendizagem de línguas, uma vez que se recorre demasiadamente a instrumentos da memória, recortes específicos da língua e combinações de enunciados da língua sem vinculação a um contexto real de uso (SATELES \& ALMEIDA FILHO, 2010). Na visão de Krashen (1982), esses instrumentos de ensino envolvem esforço consciente do aprendente para estreitar suas relações com a língua- alvo: saber as regras, saber explicá-las, ter domínio consciente sobre o conjunto de regras caracterizam um aspecto do que poderia ser classificado como aprendizagem da língua, segundo Krashen.

Para esse autor (op. cit.), aprender envolve um construto mais voluntário, diferentemente de adquirir, caracterizado como um processo mais espontâneo e em boa medida localizado no subconsciente dos aprendentes, visto que, em grande parte dos casos, os adquiridores alcançam alto nível de competência na língua sem estarem 
necessariamente atentos e empenhados no processo aquisicional de línguas. Por tanto, a abordagem gramatical parece estar mais do lado da aprendizagem do que da aquisição já que o foco na forma requer procedimentos de ensino ligados à sistematização contínua e ao ensino preventivo de cada quesito na nova língua que pouco contribuem para o desenvolvimento de competência comunicativa nos aprendizes.

Sateles \& Almeida Filho (2010), sustentam que no Brasil, por exemplo, é possível identificar indícios característicos da abordagem gramatical ao longo dos 500 anos de história do ensino de línguas no país. Eles afirmam que durante esse meio século houve muitos métodos (direto, audiolingual, sugestopédico, resposta física total, por exemplo) com traços que os distinguem uns dos outros. No entanto, trata-se de uma distinção superficial já que, em todos eles, a gramática tem sido o elemento fundante, tanto para o ensino quanto para a aprendizagem.

Na Argentina o panorama não é diferente, segundo Marín (2004, p. 17) antes e depois da década de 60 o ensino de língua materna se basea na abordagem "tradicional" (gramatical) e "estrutural" respectivamente. O primeiro enfoque usava a "teoria linguística logicista" que concebia aspectos gramaticais dependentes da lógica, com as atividades classificatórias e analíticas de conteúdos gramaticais demandantes de esforço mnemônico permanente como o centro do processo de ensino e aprendizagem. $\mathrm{O}$ enfoque estruturalista tinha uma visão reducionista da língua como disciplina de estudo por repetição e estímulo composta por vocabulário a ser classificado por formas e funções pouco considerando o significado no uso. Quanto às línguas estrangeiras, a situação tem sido muito semelhante, antes de 1956 (BEIN, 2012) predominava o ensino tradicional com ênfase na escrita e correção gramatical. Depois dos anos 60, houve uma tentativa de modernizar o ensino de LE com o "método direto" dando prioridade à língua oral, aos aspectos fonéticos e prosódicos, excluindo a língua materna e a tradução da sala de aula. Os anos subsequentes estão marcados por tentativas de levar o conceito de comunicação na LE à sala de aula. No entanto, a força da gramática sempre é usada como a orientadora de todo o processo.

A abordagem gramatical remonta ao século XVIII e ainda que até a década de 70 do século XX tenham sido desenvolvidos diversos "métodos" como o da tradução, direto, da leitura, áudio-lingual (LEFFA, 1988), em todos, a língua tem sido estudada por meio de sua estrutura gramatical, alguns com mais ênfase na oralidade, outros na tradução e outros na escrita, mas todos com a gramática como força motriz. Para Sateles 
\& Almeida Filho (2010), a "forma" é predominante até hoje como ponto de partida do processo de ensino de línguas porque talvez seja

\begin{abstract}
[...] mais seguro seguir um modelo que tem, de uma forma ou de outra, promovido a aprendizagem há séculos: ou porque é mais fácil para os professores ensinar a língua-alvo na língua materna dos alunos, já que eles não precisam ser proficiente naquela língua para ensinar partes do sistema listados num programa de curso, ou ainda porque os materiais didáticos disponíveis seguem a abordagem gramatical, então não seria necessário perder tempo preparando materiais diferenciados da abordagem comunicativa (no caso a grande opositora da abordagem gramatical).(grifo meu)
\end{abstract}

Assim, as materialidades de ensinar uma língua fundadas na abordagem gramatical se constroem com base no entendimento da língua como sistema da qual se devem aprender as estruturas e suas regras. Portanto, ensinar é equivalente a transmitir e reforçar conteúdos linguísticos. Por exemplo, na sala e suas extensões, as ações do ensinar de um professor adepto dessa abordagem incluem: explicitação de conteúdos com foco na forma, interação visando a fixação do sistema, aplicação de exercícios para preencher lacunas e/ou rotinizações com imitação, cópia, repetição com o intuito de aprender as regras e estruturas do sistema da língua, listas de vocabulário, verbos, preposições, pronomes... Na concepção de ensino do rigor gramatical, o ambiente de sala de aula é extremamente organizado tanto na sua disposição física como na disciplina e não existe uma interação real e espontânea na LE entre professor e aluno, ou entre os aprendizes. Entre outros, geralmente a aula segue o padrão tradicional "o professor pergunta, o aluno responde e o professor corrige".

Quando o professor produz seu material didático ou quando outros agentes seguidores da mesma abordagem o criam, os MDs têm como nervo central, o elemento codificador, organizador e ponto de partida "a gramática, o sistema, a forma, a estrutura da língua". Por tanto, um MD gramatical é composto por: unidades organizadas em torno de conteúdos linguísticos, caixas de gramática, exercícios para preencher lacunas, atividades de imitação, cópia e repetição com prática de estruturas e vocabulário, atividades de interação visando a fixação da forma, apêndice de gramática com tabelas de verbos e listas de vocabulário separadas por campos semânticos (ver Anexo 4 a e b). O quadro a seguir, baseado na teoria exposta, mostra as características dos indicadores 
da abordagem gramatical geralmente identificáveis nos LDs dessa linha de ensino e aprendizagem:

Tabela 6 - Características dos Indicadores de um MD da abordagem gramatical

\begin{tabular}{|c|c|c|}
\hline Unidades & Atividades & Insumo \\
\hline Organizadas a partir de & - Exercícios de prática do código & Textos (escritos ou em áudio) \\
tópicos do código & linguístico (preenchimento de & fictícios: diálogos, leituras \\
linguístico: tempos & lacunas, Verdadeiro ou Falso, & com destaque do tópico do \\
verbais, contrações, & Exercícios de Transformação... $)$ & código linguístico organizador \\
pronomes possessivos etc. & ou no padrão tradicional & danidade, figuras com \\
& "pergunta-resposta" & vocabulário. \\
\hline
\end{tabular}

Fonte: Elaborado pela autora

O processo de ensino-aprendizagem orientado por essa abordagem toma as formas da língua descritas nas gramáticas como modelo suficiente para organizar as experiências de aprender outra língua (Almeida Filho, 1993, p. 47- 48) Parece incoerente que essa concepção ainda domine o território do ensino sendo que os perfis e papéis de professores e alunos evoluíram e mudaram substancialmente ao longo dos séculos. Por isso, em torno da insatisfação com a abordagem supracitada e em oposição a ela, a partir do final dos anos 70 (SATELES\&ALMEIDA FILHO, 2010) começa a surgir uma visão antagônica para o ensino de línguas centralizada na comunicação da vida real, na construção de sentido, na comunicação verdadeira entre professores e aprendizes, a chamada Abordagem Comunicativa (AC).

\subsubsection{Abordagem Comunicativa}

Nos anos 70, a Europa arquitetava um plano político de unidade, o "Mercado Comum Europeu", depois Comunidade Europeia e atualmente União Europeia que, entre outros desafios, devia passar a ensinar e aprender a diversidade de línguas e culturas dos países participantes. Com isso, os profissionais e pesquisadores da AElin e da LA da época começaram a duvidar da eficiência dos métodos gramaticais na elaboração de um projeto de massa. A dúvida desses profissionais trouxe novos aportes teóricos dando origem a uma concepção de ensino e aprendizagem de língua com foco 
na comunicação real (ALMEIDA FILHO, 2009). Nessa época, segundo Leffa (1988), enquanto os linguistas europeus analisavam a língua como um conjunto de eventos comunicativos, os linguistas norte-americanos da linguística estruturalista de Bloomfield (1993), por exemplo, ou da gerativa transformacional de Chomsky (1965) se concentravam na análise do código da língua. A visão dos europeus estava aliada a um grande interesse pelo ensino da língua como comunicação, diferentemente da escola gerativo-transformacional que tinha como propósito o tratamento do código em si, ou seja, uma teoria da língua, e não uma teoria do ensino e aprendizagem da língua.

Inicialmente, na Europa ocidental, esse contramovimento da abordagem gramatical se chamou nocional, nocional funcional e, finalmente, comunicativo (ALMEIDA FILHO, 2009). A língua passa a ser vista como ação social, ensinar significa produzir vivências relevantes na língua alvo, norteadas por funções comunicativas numa primeira instância, e aprender inclui o desejo de adquirir uma grande capacidade de uso da nova língua. Para Leffa (1988), dessa nova concepção de língua, ensinar e aprender surgiram os inventários de noções e funções (Wilkins 1976, Van Ek 1976) que se expressam por meio da língua com o objetivo de descrever o que se faz com ela. Para Almeida Filho (2009) e Howatt (1988, p.19) a base da abordagem comunicativa foi dada pelas contribuições de Dell Hymes (a partir de 1967) com o conceito de competência comunicativa inspirado nas funções da linguagem de Roman Jakobson e pelos estudos de Austin, na Inglaterra, sobre os atos de fala. Foram Wilkins (1971, 1976) e Widdowson (1967) os que finalmente consolidaram as bases da AC com suas proposições comunicativas de base nocional-funcional. Em contraposição à abordagem anterior, a grande preocupação do movimento comunicativo de ensino de línguas começava a girar em torno do uso de linguagem apropriada, adequada à situação em que ocorre a comunicação e ao papel desempenhado pelos participantes (LEFFA, 1988).

Almeida Filho (2009) sustenta que nos anos 90 o linguista aplicado Nagore Prabhu trouxe uma "sugestão ressignificadora" da visão comunicativa de ensino de línguas. Em 1987, Prabhu implementava e coordenava um projeto de ensino de inglês baseado em tarefas em escolas primárias e secundárias de Bangalore, na Índia. Nesse projeto, Prabhu revelou o uso e o significado do termo "comunicacional" para descrever a visão de pedagogia de segunda língua subjacente ao mesmo. De acordo com o autor indiano, o termo "comunicacional" se contrapõe ao termo comunicativo porque a 
concepção de desenvolvimento de competência em L2 vai além da "sistematização de inputs da linguagem e/ou da maximização de práticas planejadas conforme subentendido no ensino comunicativo". No Projeto Bangalore, objetivou-se criar condições para que os aprendizes se engajassem num esforço para lidar com a comunicação. Essas condições foram dadas pelo desenvolvimento e emprego de tarefas em sala de aula. Prabhu (1987, p.24) define a tarefa como uma "atividade que requer do aprendiz chegar a um resultado a partir de uma dada informação, através de algum processo de pensamento, controlado e regulado pelos professores.

A partir das reflexões de Prabhu, as pesquisas sobre o ensino de línguas baseado em tarefas se intensificaram com Candlin \& Murphy (1987), Nunan (1989; 2004), Crookies \& Gass (1993), Willis (1996), Bygate, Skehan \& Swain (2001), Ellis (2001) e Willis e Willis (2007). No Brasil, no final dos anos 70 (1977), Almeida Filho introduzia o ensino comunicativo e, nos anos 90, o mesmo autor (1993, p.47-48) influenciava o pensamento do autor indiano ao definir o ensino comunicativo de LE como

[...] aquele que organiza as experiências de aprender em termos de atividades/tarefas de real interesse e/ou necessidade do aluno para que ele se capacite a usar a língua-alvo para realizar ações de verdade na interação com outros falantes-usuários dessa língua. $\mathrm{O}$ ensino comunicativo é aquele que não toma as formas da língua descritas nas gramáticas como modelos suficientes para organizar as experiências de aprender outra L. mas, sim aquele que toma unidades de ação feitas com linguagem como organizatórias das amostras autênticas de língua-alvo que se vão oferecer ao aluno-aprendiz

O autor (ibid.) prossegue com alguns exemplos do que significa aprender nessa modalidade de ensino:

1. Poder desempenhar uma sequência de atos: cumprimento, socialização casual (fática), convite, arranjos e despedida

2. Descrever com a ajuda de um objeto ou sua representação o funcionamento de um aparelho ou experimento

3. Aprender o sistema ecológico da Amazônia via língua-alvo que se está aprendendo e no andamento sistematizar essa L no que for necessário para facilitar ou solidificar o processo de aprender

4. Calibrar um início de conversa com um superior ou desconhecido para atuar no registro certo. 
No exemplo número 3, o autor evidencia adesão também ao ensino de conteúdos de outras matérias para o ELE (Ensino de Língua Estrangeira) proposto por Widdowson (1978). Almeida Filho (1993, p. 59) assevera que com a utilização de textos de outras disciplinas o professor poderia, por um lado, garantir que eles "não fossem meros mostruários de vocabulários", e por outro, "projetar a atenção dos alunos para algo além da sala de aula que valesse a pena ser aprendido". O autor (ibid) argumenta que esses textos representariam o uso autêntico da língua estrangeira, os assuntos tratados não só seriam comunicativamente relevantes como linguisticamente apropriados. Tais materiais também permitiriam o uso de recursos não linguísticos (experimentos, mapas, quadros, diagramas, desenhos). Enfim, o uso de conteúdos de outras grandes áreas do conhecimento (História, Geografia etc.) para o ensino de LE permite adquirir novos conhecimentos ao mesmo tempo em que se aprende uma nova língua.

Esse mesmo autor (p. 43) esclarece, ainda, entre os vários significados de ser comunicativo, que a AC não condena o uso de exercícios mecânicos de substituição nem o oferecimento de condições para a aprendizagem consciente de regularidades linguísticas já que embasam o uso comunicativo extensivo da língua. Em uma aula comunicativa, por exemplo, pode haver exercícios mecânicos de substituição para subsistemas linguísticos como os pronomes, terminações de verbos, substantivos, sempre que requisitado pelos alunos ou percebida a necessidade pelo professor.

Voltando os olhares para o material didático disponível para o ensino de línguas, é possível observar que muitos deles guardam ainda traços de uma abordagem tradicional e estruturalista de ensinar-aprender pouco preocupada com 0 desenvolvimento da almejada competência comunicativa ou com foco no aprendiz e a produção de significado. No geral, encontra-se nesse tipo de materiais um tratamento flexibilizado da gramática, contextualizada/camuflada em situações comunicativas. Temos nesse caso uma variante atualíssima da AC, a "Abordagem Gramatical Comunicativizada" (AGC). NA AGC o ponto de partida das atividades organizadoras das experiências de ensinar e aprender a nova língua continua sendo o código linguístico, a gramática, as estruturas, camufladas em atividades que envolvem "situações de comunicação fictícias" ou no padrão tradicional de "o professor pergunta e o aluno responde". Nessa abordagem há uma tentativa de ensinar o que se faz com a língua na vida real, ou seja negociar significados, mas ainda está na metade do caminho do que é ensinar na abordagem comunicativa. No Capítulo de Análise de Registros 
voltarei a abordar esse assunto durante a análise das atividades pré-comunicativas encontradas nas coleções didáticas de PLE.

Outro matiz da abordagem comunicativa, a chamada ACIN (Abordagem Comunicativa Intercultural) proposta por Mendes (2008), é declarada pelos autores dos dois livros analisados nesta dissertação como a norteadora da construção dos didáticos de PLE produzidos na Argentina. Segundo Mendes (2008, p. 153), nessa "nova abordagem" o termo intercultural refere-se à "ação integradora, capaz de suscitar comportamentos e atitudes comprometidas com princípios orientados para o respeito ao outro, às diferenças, à diversidade cultural que caracteriza todo processo de ensino aprendizagem". No entanto, cabe destacar que isso já é próprio da abordagem comunicativa. Também darei maior ênfase às teorizações sobre como deve ser a estrutura e o conteúdo de um MD produzido nessa variante da AC por envolver diretamente a análise dos dois materiais didáticos escolhidos para análise.

Para finalizar, se considerarmos todas as características sobre a macroabordagem comunicativa expostas até aqui e pensarmos nelas codificadas num material didático, esse deveria ser organizado por: desenvolvimento de tópicos das grandes áreas do conhecimento (Widdowson, 1978) ou por unidades temáticas com textos/insumo autêntico de interesse dos aprendentes (áudios, sites, folhetos, vídeos, recortes de revistas, jornais...) contendo atividades (relevantes ao processo)/tarefas (Prabhu 1987, Skehan, 1996 ) (tradução, levantamento e/ou comparação de informações, tomada de decisão, reprodução de conversa gravada, tradução), jogos e projetos (ALMEIDA FILHO, 1993, p. 75). Todas essas atividades dão chance ao aprendiz de interagir visando a comunicação e o uso propositado da língua-alvo na sala de aula e suas extensões para atingir o objetivo maior de adquirir competência comunicativa.

Um material didático nessa perspectiva, por exemplo, pode propor assistir a um vídeo, tomar notas, ler e compará-las com as do colega, discutir algum ponto de interesse para se chegar a um consenso (em duplas, com outros grupos da classe, com o professor), ou que leve à solução de algum problema sobre o tópico proposto, sempre do interesse dos alunos. Para Almeida Filho (2012) esse tipo de materiais, "em menor proporção", pode ter "eventuais exercícios de sistematização e rotinização dependendo da demanda dos aprendentes e não propostos preventivamente.” Enfim, a Abordagem Comunicativa se oferece como a lógica e filosofia que possibilita codificar as ações para selecionar, avaliar ou produzir materiais de ensino de línguas voltados para aumentar as 
chances de os aprendizes de adquirirem uma nova língua. A seguir, apresento os indicadores de um MD da AC baseado na teoria exposta:

Tabela 7 - Indicadores de um MD da Abordagem Comunicativa

\begin{tabular}{|c|c|c|}
\hline Unidades & Atividades & Insumo \\
\hline $\begin{array}{c}\text { Organizadas a partir de } \\
\text { tópicos de interesse dos } \\
\text { alunos, unidades temáticas } \\
\text { ou organizadas por } \\
\text { conteúdos das grandes } \\
\text { áreas do conhecimento. }\end{array}$ & $\begin{array}{c}\text { Comunicativas: tarefas } \\
\text { (desempenho de papéis, debates, } \\
\text { tradução, solução de problemas, } \\
\text { lacunas de opinião, troca de } \\
\text { informação) projetos, jogos. }\end{array}$ & $\begin{array}{c}\text { Material autêntico: textos escritos } \\
\text { ou orais de boa qualidade e } \\
\text { quantidade (recortes de jornais, } \\
\text { revistas, fotografias com legendas, } \\
\text { música, publicidades, vídeos, } \\
\text { filmes) }\end{array}$ \\
\hline
\end{tabular}

Fonte: Elaborado pela autora

Cabe destacar que os princípios descritos de cada abordagem foram o eixo norteador para a análise de dados do Capítulo 4. Por isso, ainda ampliarei nesse capítulo a fundamentação teórica sobre princípios e características dos indicadores da AGC e da AC para com eles identificar a abordagem de um MD durante a tarefa de seleção/adoção/avaliação de didáticos dos professores de línguas. Foi a partir da própria análise de dados que os princípios das abordagens em questão me deram suporte para definir e fundamentar os constituintes, além de outras taxonomias surgidas a partir da análise dos próprios materiais.

O capítulo subsequente traz o referencial metodológico que deu suporte para coletar os registros, analisar e interpretar os dados. 


\section{METODOLOGIA}

\section{Introdução}

Considero que para responder aos objetivos propostos, o mais adequado é desenvolver um estudo de caso qualitativo de cunho interpretativista, na modalidade de análise documental.

Os documentos selecionados para análise envolveram materiais didáticos para $\mathrm{o}$ ensino de PLE produzidos na Argentina. Esses documentos foram a principal fonte de informação para a pesquisa que aqui relato.

A opção de realizar um estudo de caso envolvendo a análise desses materiais documentais inseridos no contexto do MERCOSUL, no "subcontexto" do ensino de PLE na Argentina, oferece a possibilidade de retratar e teorizar sobre a recente produção de didáticos nesse país, sua adoção nos estabelecimentos educativos e os avanços da inclusão do português no currículo do ensino médio e fundamental da escola pública argentina. Assim, na pesquisa, foi abordado um estudo de caso que compreende um fenômeno educacional complexo.

Neste capítulo, apresento as principais características da pesquisa qualitativa de natureza interpretativista, os princípios norteadores do estudo de caso em sua modalidade de análise documental, sua fundamentação, os documentos analisados, o contexto de pesquisa e a exposição de procedimentos de coleta e análise de dados.

\subsection{A pesquisa qualitativa de cunho interpretativista}

Stake (2011, pag. 21) assevera que a ciência está repleta de pensamento qualitativo, ou seja, o tipo de pensamento em que o raciocínio se baseia principalmente na percepção e na compreensão humana. Para o autor (ibid. p. 23), o pensamento qualitativo oferece um fundamento ou uma disposição para o pensamento quantitativo. Ele ainda afirma que o primeiro "é muito mais" e está mesclado com todas as etapas do trabalho científico, da pesquisa. Assim, Stake (ibid. p. 23-24) define pesquisa qualitativa como investigação, estudo deliberado, busca pela compreensão de como as 
tudo que se relaciona aos humanos funciona em situações particulares e atribui certas características a ela: interpretativa, experiencial, situacional, personalística, bem triangulada, bem informada, com opções estratégicas.

Segundo Stake (ibid. p. 24), as pesquisas sobre práticas do ensino e aprendizagem são especificamente interpretativas, experienciais, situacionais e personalísticas. Identifico predominantemente a primeira característica na pesquisa que aqui relato. Ela é de cunho interpretativista, uma "batalha com os significados" (ibid. p. 49) delineados a partir da análise de abordagem dos materiais didáticos para o ensino de português para estrangeiros. Entendo que as compreensões de casos particulares podem ser falhas. Por isso, ao longo de todo o trabalho, tenho me empenhado em "objetivar a subjetividade" das minhas interpretações (LAVILLE \& DIONE, 1999, p. 44). O objetivo-mor nunca foi analisar os materiais apenas, mas usar a análise de abordagem desses como caminho inicial para delinear orientações (baseadas na análise de abordagem) sobre como um professor pode selecionar reflexivamente materiais didáticos para o ensino de uma nova língua em diversos contextos de ensino.

Escolhi a perspectiva qualitativa porque como pesquisadora posso me relacionar com o fenômeno de meu interesse, compreendê-lo e descrever as experiências pessoais relacionadas a ele (JOHNSON \& ONWUEGBUZIE, 2004). Diferentemente da modalidade quantitativa, posso assumir uma postura diante da pesquisa. Além disso, na modalidade quantitativa o pesquisador pode não perceber alguns fenômenos por causa do foco na teoria e na testagem de hipóteses, o que, a rigor, numa perspectiva qualitativa, poderia gerar novas hipóteses ou teorias, uma vez que, com [...] a ênfase na totalidade, o pesquisador volta-se para a multiplicidade de dimensões do problema, focalizando-o como um todo (GIL, 1991, p. 58-60).

\subsection{O estudo de caso}

Segundo Freebody (2003, p. 75), o estudo de caso é o estudo de uma instância particular de uma experiência educacional que tenta obter compreensões teóricas e profissionais da natureza da instância a partir da documentação completa da mesma. Na área do ensino e aprendizagem, Freebody (2003, p. 81) afirma que o estudo de caso é uma metodologia predominante já que oferece vantagens para organizar discussões sobre as atividades da pesquisa e é um meio para: 
a- a realização e divulgação de pesquisas que impactam sobre a prática;

b- refinar as maneiras em que a prática é teorizada;

c- criar uma ponte de trabalho e intercâmbio entre o pesquisador e os participantes da pesquisa;

d- mostrar um forte senso de tempo e lugar específicos, de condições particulares de ensino e de aprendizes particulares que moldam os processos de ensinar e de aprender.

Na educação, prossegue afirmando Freebody (2008, p. 82), para um caso ser estudado, a "instância particular" deve ter as seguintes características:

1- Intenção: um plano, itinerário ou propósito, informal ou formal.

2- Eventualidade: uma intenção que é interrompida pela surpresa, uma falha, algo inesperado.

3- Avaliação: julgar quando não há respostas disponíveis para solucionar uma falha.

4- Reflexão: o exame das consequências das medidas tomadas à luz do julgamento produz a base para um novo plano.

Para Merriam (1998, p. 8), “é a unidade de análise e não o tópico de pesquisa o que caracterizam um caso". Por isso, a mesma autora (ibid.), afirma que "o estudo de caso é uma descrição e análise intensas sobre um fenômeno ou situação social como um indivíduo, grupo, instituição ou comunidade".

No estudo de caso, os objetivos do pesquisador, esclarece Freebody (op. cit.), são, por um lado inserir um questionamento em que ele e os educadores possam refletir sobre uma instância particular da prática educativa e, pelo outro, documentar:

a- a história de um experimento naturalista em ação;

b- a rotina que mobiliza os educadores e alunos a construírem um espaço claramente conhecido e definido discursivamente, conceitualmente e profissionalmente (o caso);

c- a consequência das ações dessas pessoas, previstas e não, para a aprendizagem e para o rumo do projeto de pesquisa. 
Quanto aos objetivos dessa metodologia de trabalho, Merriam (1998, p. 8) acrescenta que, por meio da concentração em um fenômeno ou entidade particular, o estudo de caso empenha-se em "descrever o fenômeno em profundidade" já que foi selecionado porque é peculiar, único, experimental, ou bem sucedido.

Para Freebody (2003, p. 83), a metodologia do estudo de caso é desenvolvida em cinco etapas. A primeira define, esclarece a pergunta de pesquisa, pois o entendimento do âmbito em que se foca é muito importante como uma maneira de entrar no campo. Informações culturais, históricas, políticas e características pessoais dos participantes ajudam a esclarecer a pergunta sobre o caso. Na segunda etapa, deve ser feita a planificação da coleta de registros, esclarecer que tipo de caso será pesquisado para, na fase seguinte, coletar os registros de maneira completa, múltipla e sistemática. Uma coleta desse tipo permite analisar com precisão e eficiência tudo o que não pareceu relevante no momento da coleta. Ao analisar os dados na quarta etapa, deve-se contrastar e comparar as interpretações, expandir a relevância do projeto por meio do desenvolvimento de descobertas imprevistas e interpretações que diferem da asserção original. Por último, é necessário transmitir toda a experiência de maneira coerente para o leitor no relatório da pesquisa, o qual visa a explorar um fenômeno complexo e integrado, que deve ser revisado pelos participantes do estudo.

O estudo de caso apresentado nesta dissertação que trata da produção argentina de materiais didáticos para o ensino de PLE, apresenta algumas condições especiais que o situam na submodalidade de análise documental. As classificações são puramente didáticas, segundo Bogdan \& Biklen (1998, apud MOURA FILHO, 2005, p. 110) cada tipo de estudo de caso [...] tem condições especiais para ser adequado à pesquisa que se pretende realizar com procedimentos específicos a serem empregados adequadamente[...]. Na próxima seção esclareço os princípios que nortearam este estudo.

\subsection{A Análise Documental}

Bogdan \& Biklen (1998, apud MOURA FILHO, 2005, p. 111) destacam a modalidade "análise documental" do estudo de caso como um tipo de investigação em que: 
[...] as fotografias, os vídeos, os filmes, os apontamentos, as cartas, os diários e registros de casos clínicos são utilizados como fontes de informações suplementares em pesquisas cujas técnicas principais são a observação participante ou as entrevistas.

No entanto, na pesquisa relatada nesta dissertação, os documentos são o objeto de estudo que integram a análise central. May (2004, p. 206) chama esse tipo de investigação de “pesquisa documental”. Ludke \& André (1986 p. 38) usam outro termo, afirmam que a análise documental "busca identificar informações factuais nos documentos a partir de questões ou hipóteses de interesse", embora seja esta uma técnica do estudo de caso de pouco uso na área educacional. Como visto, a terminologia usada para nomearem o uso de documentos nas investigações científicas difere de um autor para outro.

Um enfoque mais abrangente para essa questão é o de Minayo (2008, p. 22) quem afirma que [...] a metodologia inclui as concepções teóricas de abordagem, o conjunto de técnicas que possibilitam a apreensão da realidade e também o potencial criativo do pesquisador [...] Logo, entendo que a análise documental também é um tipo de pesquisa que se vale dos documentos como principal fonte de informação, utilizando métodos e técnicas para a coleta de registros, apreensão, compreensão e análise de documentos.

O corpus desta pesquisa é composto principalmente por documentos, livros e outros textos escritos, que não são apenas textos escritos ou impressos (FIGUEIREDO, 2007) uma vez que são a principal fonte de informação e esclarecimento para elucidar o tópico, as questões de interesse da pesquisa. Nesse sentido, Oliveira (2007, p. 69) explica que a pesquisa documental recorre a materiais que ainda não receberam tratamento analítico, ou seja, fontes primárias e por isso o trabalho do pesquisador requer análise mais cuidadosa.

A mesma autora (ibid.) explica a necessidade de compreender uma fonte primária como os dados originais, a partir dos quais se tem uma relação direta com as asserções a serem analisadas, sendo o pesquisador quem analisa. Na pesquisa que aqui relato, os materiais didáticos escolhidos são fonte primária de dados, pois nenhum deles ainda recebeu o tratamento científico aqui proposto. 


\section{4 - Os documentos}

Como visto anteriormente, um documento não é apenas um texto escrito ou impresso, mas uma fonte de informação registrada, formando uma unidade que possa servir para consulta, estudo ou prova (APPOLINARIO, 2009, p. 69 apud SÁ SILVA et al. 2009, p. 8). Entendo os documentos estudados nesta pesquisa como a fonte primária de informação que permitiu teorizar sobre os questionamentos de interesse apresentados no capítulo anterior e analisar:

Tabela 8 - Documentos da pesquisa

\begin{tabular}{|c|c|c|}
\hline $\begin{array}{c}\text { Ano de } \\
\text { publicação }\end{array}$ & Título & Autores \\
\hline 2013 & $\begin{array}{c}\text { Coleção "Brasil Intercultural" - } \\
\text { língua e cultura brasileira para } \\
\text { estrangeiras }\end{array}$ & Casa do Brasil - Argentina \\
\hline 2010 & $\begin{array}{c}\text { Horizontes - Rumo a Proficiência } \\
\text { em Língua Portuguesa }\end{array}$ & $\begin{array}{c}\text { ALMEIDA, Adriana, BARBOSA, Cibele - } \\
\text { (Brasil/Argentina) }\end{array}$ \\
\hline
\end{tabular}

Fonte: elaborado pela autora

\subsection{O contexto}

Quanto ao contexto, considerando esse como algo que envolve as pessoas presentes, os valores culturais predominantes, as operações e as exigências da própria atividade (GALLIMORE \& GOLDBENRG, 1993), é o MERCOSUL o âmbito no qual estão inseridos o pesquisador e os documentos da pesquisa relatada nesta dissertação. Como se trata de um bloco sócio-econômico-cultural formado por vários países, cabe destacar que neste trabalho é focado o "sub-contexto" da relação bilateral ARGENTINA-BRASIL no marco do ensino de línguas oficiais desse bloco, com ênfase no ensino e na produção de materiais didáticos para o ensino de português na Argentina. 


\title{
3.6 Coleta de registros
}

Segundo Freebody (2003, p. 83), a coleta e o armazenamento de registros é uma fase da pesquisa que requer uma organização sistematizada por parte do pesquisador. A sistematização da coleta e armazenamento de registros permite consultar e rever as informações em posteriores análises e detectar dados significativos que não foram considerados importantes em uma primeira análise.

Na perspectiva da pesquisa qualitativa, os dados estão baseados nas categorias de significado dos participantes e são coletados em menor número de casos ou sujeitos, o que possibilita maior profundidade da análise, sempre buscando a visão holística.

Nas pesquisas qualitativas, Merriam (1998, p. 5) reconhece o pesquisador como “o principal instrumento para a coleta de registros e análise de dados”. A autora explica

\begin{abstract}
Desde que a interpretação é o objetivo desta pesquisa, o instrumento humano, que é capaz de reagir imediatamente e adaptar-se, parece ser o meio ideal para a coleta de registros e análise de dados. Outras vantagens são que o pesquisador (a) pode ampliar seu entendimento da comunicação não verbal como da verbal, processar informação imediatamente, elucidar e resumir dados, verificar com critério a precisão das interpretações, e explorar respostas inesperadas ou inusuais.
\end{abstract}

Para Sá Silva et al. (2009, p. 8), o pesquisador deve selecionar os textos de maneira pertinente e avaliar sua credibilidade assim como a sua representatividade. A seleção dos documentos adequados para análise constitui a primeira etapa de toda a análise documental que se aplica em cinco dimensões.

Segundo Cellard (2008, p. 300-305) o contexto, o autor, a autenticidade e confiabilidade do texto, a natureza do texto, os conceitos chave e a lógica interna do texto são as cinco dimensões que o pesquisador deve considerar para uma seleção pertinente dos documentos a serem analisados. Cabe destacar que o enfoque do autor supracitado (ibid.) é específico para pesquisas documentais historiográficas. No entanto, entendo que há muitos pontos de contato entre a forma em que foram selecionados os documentos nesta pesquisa e as cinco dimensões que esse autor propõe (ibid.): 
a- $\underline{O}$ contexto: deve-se avaliar o contexto histórico no qual foi produzido o documento, o universo sociopolítico do autor e daqueles a quem foi destinado, seja qual for a época em que tenha sido escrito.

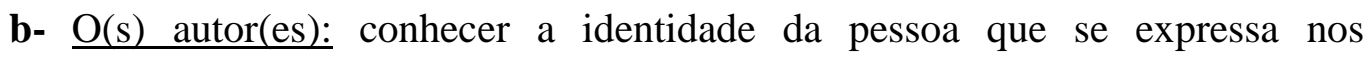
documentos possibilita avaliar melhor a credibilidade do texto, a interpretação que é dada de alguns fatos e a tomada de posição que transparece de uma descrição.

c- A autenticidade e confiabilidade do texto: não se deve esquecer da procedência do texto. É necessário estar atento à relação existente entre o autor e o que ele escreve.

d- A natureza do texto: a estrutura de um texto pode variar enormemente conforme o contexto no qual ele for redigido. Quando se trata de textos jurídico, teológico ou médico, que são estruturados de forma diferente, só adquirem sentido para o leitor em função do seu grau de iniciação no contexto particular de sua produção.

e- Os conceitos chave e a lógica interna do texto: por um lado, deve-se prestar atenção aos conceitos-chaves presentes em um texto e avaliar sua importância e seu sentido, segundo o contexto preciso em que eles são empregados. Por outro lado, deve-se examinar a lógica interna do documento, ou seja, como se desenvolve sua argumentação e quais são suas partes principais.

Stake (p. 102) afirma que [...] o método para coletas de dados é escolhido para se adequar à questão de pesquisa e ao estilo de investigação que os pesquisadores preferem usar [...]. Na pesquisa aqui relatada, para coletar parte dos dados, viajei à Argentina e comprei as coleções de livros didáticos para o ensino de português nesse país. Um terceiro livro foi cedido pelo Orientador desta pesquisa, o Prof. Dr. José Carlos Paes de Almeida Filho. Os documentos sobre a engenharia de um desses materiais foram enviados pelo Diretor da Casa do Brasil em Buenos Aires, Fabrício Muller, ele também contribuiu com uma narrativa escrita em comunicação pessoal através de TICs sobre a elaboração do material da escola de línguas que lidera. 


\section{7 - A Análise de dados}

Bogdan \& Biklen (1998, p.157) definem a análise de dados qualitativa como

[...] um processo sistemático de exploração e organização de entrevistas, notas de campo e outros materiais que você acumula para ampliar sua própria compreensão sobre eles e para capacitá-lo(a) a apresentar o que você descobriu para outros. A análise envolve trabalhar com os dados, organizálos, dividi-los em unidades manejáveis, sistematizá-los, identificar padrões, descobrir o que é importante, o que é para ser aprendido e decidir o que você contará aos outros.

Os mesmos autores (1998, p. 158) asseveram que para aprender a "gerenciar" o processo de análise de dados é necessário trabalhar com eles, testar diferentes abordagens e estilos que combinem com a pesquisa. Pois não há uma "receita" com os procedimentos para a análise de dados para cada projeto de pesquisa.

As autoras Ludke \& André (1986, p. 38) destacam a "análise de conteúdos" como a metodologia mais utilizada nos estudos de caso documentais. A análise de conteúdos é uma técnica de pesquisa destinada a fazer inferências válidas e replicáveis dos dados para seu contexto. Appolinário (2009, p. 27) afirma que a análise de conteúdo é um

Conjunto de técnicas de investigação científica utilizada em ciências humanas, caracterizada pela análise de dados linguísticos [...] Normalmente, nesse tipo de análise, os elementos fundamentais da comunicação são identificados, numerados e categorizados. Posteriormente as categorias encontradas são analisadas face a uma teoria específica.

Segundo as autoras supracitadas (op.cit., p. 47) o processo de análise de conteúdos tem início com a escolha de uma unidade de análise

Há dois tipos de unidade: a de registro e a de contexto. Na primeira, selecionam-se segmentos específicos do conteúdo, como, por exemplo, a frequência com que aparece no texto uma palavra, um tópico, um tema, uma expressão, uma personagem ou um determinado item. Em outros casos, será preferível analisar o contexto em que uma unidade dada ocorre. 
Para a pesquisa que aqui relato acredito que o mais adequado foi utilizar ambas as unidades de análise, pois era a única maneira de descrever e analisar as características dos livros didáticos para o ensino de PLE editados na Argentina e sua ligação com as duas macroabordagens explanadas na fundamentação teórica. As informações coletadas a partir das unidades de análises podem ser registradas de diversas maneiras, com anotações nas margens do próprio material analisado, esquemas, diagramas, no computador. Essa escolha de como registrar as informações é uma primeira etapa de classificação dos dados.

Não obstante, para Ludke \& André (ibid.) a etapa mais importante é a criação de categorias ou categorização dos dados. A leitura e releitura dos dados coletados é um processo essencialmente indutivo que [...] vai culminar na construção de categorias ou tipologias [...] (LUDKE \& ANDRÉ, 1986, p. 48). Em um primeiro momento, as categorias surgem da teoria em que se apoia a investigação. Esse conjunto de categorias pode ser chamada "preliminares" já que vai se modificando ao longo do estudo. A criação das categorias está em estreita relação com as perguntas da pesquisa e devem refletir o propósito da pesquisa (GUBA \& LINCOLN, 1981 apud SÁ SILVA et al, p. 12).

Nesse sentido, cabe destacar o ponto de vista de Ludke \& André (op. cit.):

Não existem normas fixas nem procedimentos padronizados para a criação de categorias, mas acredita-se que um quadro teórico consistente pode auxiliar uma seleção inicial mais segura e relevante.

As autoras (ibid.) sugerem alguns princípios para a construção de categorias. Aos fins práticos, detalho sugestão delas em forma de passos, o que não quer dizer que essa seja a ordem certa a ser seguida para a criação das categorias:

1- Exame do material procurando encontrar os aspectos relevantes.

2- Verificação de certos temas, observações e comentários que aparecem e reaparecem em contextos variados, vindos de diferentes fontes e diferentes situações. 
3- Verificação de certos aspectos que aparecem com certa regularidade sendo, assim, a base para o primeiro agrupamento da informação em categorias.

4- Certificação de que os dados que não puderem ser agregados devem ser classificados como um grupo à parte para serem posteriormente examinados.

No que se refere à categorização dos dados, Guba \& Lincoln (1981, apud SÁ SILVA et al., 2009, p. 12-13 ) apontam alguns critérios que podem auxiliar o pesquisador a avaliar com mais cautela as categorias "preliminares" que foram originadas do material documental: a homogeneidade interna, a heterogeneidade externa, inclusividade, coerência e plausibilidade. Os autores (op. cit.) querem dizer que quando uma categoria abrange um único conceito, todos os itens nessa categoria devem ser homogêneos, devem estar coerentemente integrados. Por último, afirmam que as categorias devem ser mutuamente exclusivas, de modo que as diferenças entre elas fiquem bem claras.

Afinal, organizar os dados em categorias implica classificá-los por aspectos comuns ou de relação entre si. As categorias permitem [...] agrupar elementos, ideias ou expressões em torno de um conceito capaz de abranger tudo isso [...] (GOMES, 1994, p. 68 apud MOURA FILHO, 2005, p. 130).

De acordo com o enfoque de Ludke \& André (1986), Guba \& Lincoln (1981, apud SÁ SILVA et al. 2009), Bogdan \& Biklen (1998), Gomes (1994,apud MOURA FILHO, 2005), da leitura e releitura de dados surge a identificação de "padrões" para ratificar as categorias de análise observadas ao longo do trabalho. No caso das categorias identificadas durante o desenvolvimento da pesquisa relatada nesta dissertação, o suporte da revisão bibliográfica e o processo de coleta de dados foram fundamentais.

Cabe destacar que não encontrei bibliografia específica que aponte como se analisa a abordagem de um material didático para o ensino de línguas estrangeiras. Por isso, tomei como modelo motivador para coleta de registros e análise dos dados e construção de categorias, alguns parâmetros da ficha de avaliação do Guia do PNLD (Programa Nacional do Livro Didático) criado no Brasil e de fichas e princípios de avaliação de MDs de outros autores resenhados no marco teórico, capítulo segundo 
desta dissertação. No entanto, não satisfeita com o tipo de categorias oferecidas por esse documento, baseei-me nos princípios da Abordagem Comunicativa e da Abordagem Gramatical para criar questões/categorias para a análise dos materiais, todas fundamentadas na teoria de autores renomados. Como consequência desse trabalho surgiu uma taxonomia de atividades de materiais didáticos a ser apresentada no próximo capítulo.

Por último, para a interpretação das informações coletadas, lidas, relidas, padronizadas e categorizadas, a própria análise documental e de abordagem contrastada com a teoria forneceu a interpretação. Isso significa que os documentos analisados foram interpretados de acordo com o que eu vi neles, com suporte do arcabouço teórico e os dados coletados, sempre tendo como norte os questionamentos e os tópicos de interesse desta pesquisa, apresentados no capítulo anterior. Esses foram os procedimentos utilizados já que a principal fonte de dados foram documentos. Cabe salientar que durante a interpretação também utilizei ferramentas gráfico-numéricas para ilustrar os dados obtidos da análise dos materiais didáticos. No entanto, considero que isso não modifica a essência qualitativa da pesquisa.

Por meio desses procedimentos, pude analisar a abordagem dos MDs de PLE elaborados na Argentina. Reservei todos esses detalhes para subsidiar a exegese empreendida no próximo capítulo. 


\section{ANÁLISE DE DADOS}

\section{Introdução}

Neste capítulo pretendo apresentar os dois livros didáticos selecionados, os critérios para essa seleção e explicar as questões, categorias e fundamentos teóricos empregados para obter e analisar os dados e interpretá-los. Também tenho em mente ilustrar os dados e as interpretações com gráficos e desenhos para melhor apreciação dos resultados obtidos. Além disso, respondo os questionamentos estabelecidos na introdução desta dissertação e, finalmente, reafirmo a proposta da análise de abordagem como procedimento promissor para professores de línguas, avaliarem selecionarem/adotarem materiais didáticos para o ensino de novas línguas.

\subsection{OS LIVROS DIDÁTICOS SELECIONADOS}

\subsubsection{Brasil Intercultural: língua e cultura brasileira para estrangeiros}

"Brasil Intercultural" (BI) é uma coleção de livros didáticos para o ensino de Português como Língua Estrangeira (PLE) editada pela Casa do Brasil em Buenos Aires (Argentina). Em 2010, essa instituição comemorou seus 20 anos de trabalho e se transformava numa escola de referência para o ensino e a difusão da língua portuguesa, ao oferecer à comunidade cursos de língua, cultura e, também, no plano da Formação Docente Continuada, congressos (como o Congresso SIPLE no ano 2008), seminários e cursos para professores. Nesse mesmo ano, a escola se transformou num posto aplicador do exame CELPE-BRAS e segundo um dos seus diretores, Fabrício Muller, isso os

[...] "obrigava" a ter o primeiro efeito retroativo já que a concepção e metodologia desse exame de proficiência eram bastante diferentes das utilizadas até então em nossa instituição, e por que não dizer também, na maioria das instituições ${ }^{3}$ (comunicação pessoal).

3 [...] nos "obligaba" a tener el primer efecto retroactivo ya que la concepción y metodología de dicho examen de proficiência era bastante diferente a la utilizada hasta entonces en nuestra institución, y por qué no decirlo, en la mayoría de las instituciones. 
Dessa maneira, a Casa do Brasil constatou a necessidade de produzir seu próprio material didático para atender às exigências e características avaliativas do exame CELPE-BRAS e satisfazer as necessidades dos alunos e professores da própria e de outras instituições que manifestavam a conclusão de não se identificar mais com os livros que chegavam do Brasil. A abordagem intercultural, o conceito de língua em uso, a oferta de diversos gêneros textuais e a focalização no público hispanofalante foram as necessidades identificadas para codificação do novo material. BI foi produzido por uma equipe de professores sob a coordenação da especialista acadêmica Edleise Mendes, da Universidade Federal da Bahia, e faz parte do acervo de livros didáticos para o ensino e aprendizagem de PLE elaborados fora do Brasil.

Nesta dissertação, refiro-me a Brasil Intercultural como uma coleção por tratarse de 3 volumes de livros didáticos organizados por ciclos e níveis: BI Ciclo Básico (Livro do aluno e Livro de exercícios): Níveis 1 e 2, BI Ciclo Intermediário (Livro do Aluno e Livro de exercícios): Níveis 1 e 2 e BI Ciclo Avançado (Livro do Aluno e Livro de Exercícios): os Níveis 1 e 2 foram recentemente lançados no mercado editorial argentino. Considero que cada volume da coleção constitui um "livro didático" (LD) por tratar-se de um material impresso composto sequencialmente por conteúdos de gramática, vocabulário, pronúncia, funções, leitura, escrita, áudios e exercícios de produção oral. Cada volume traz o máximo de insumo para o nível e uma sequência de ensino e aprendizagem preconcebida (TOMLINSON, 1998, p. 9). Cabe salientar que na pesquisa aqui relatada foi analisado somente o primeiro volume da coleção, Ciclo Básico (Nível 1 e 2) composto pelo livro do aluno e de exercícios. A coleção não possui CD já que os áudios e vídeos estão disponíveis para serem baixadas do site da Casa do Brasil, (www.casadobrasil.com.ar)

Quanto às autoras do material, elas são brasileiras, formadas na área de Letras e quando a coleção começou a ser produzida elas se desempenhavam como professoras de português na Casa do Brasil:

a- Aline Moreira: possui graduação em língua espanhola e Literaturas da Língua Espanhola pela Universidade Federal Catarinense (UFSC) (Plataforma Lattes).

b- Cibele Nascente Barbosa: é formada em Letras, Licenciatura, pela Universidade Federal do Rio Grande do Sul (2003). É mestranda (2004) em 
Linguística na UAA (Universidade Autônoma de Assunção) (Plataforma Lattes).

c- Giselle Nunes de Castro: possui graduação em Letras. Universidade do Estado do Rio de Janeiro, UERJ, Brasil. (2005) Foi professora de português na Casa do Brasil durante a produção do livro em questão. (Plataforma Lattes).

O trabalho das autoras esteve sob coordenação da Prof. Dra. Edleise Mendes, doutora em Linguística Aplicada pela Unicamp e atualmente professora adjunta da Universidade Federal da Bahia na graduação e no Programa de Pós-graduação em Língua e Cultura. A especialista acadêmica Edleise Mendes se dedica a estudos sobre a língua portuguesa e contextos culturais que a abrigam, atuando principalmente nos seguintes temas: ensino e aprendizagem de língua portuguesa, materna e estrangeira, formação de professores, avaliação e produção de materiais didáticos, abordagens interculturais e críticas para o ensino de línguas. Também coordena o Grupo de Pesquisa LINCE - Núcleo de Estudos em Língua, Cultura e Ensino (UFBA/CNPQ) e é a atual presidente da Sociedade Internacional de Português Língua Estrangeira - SIPLE (2011-2014) (Plataforma Lattes).

Creio ser importante destacar que a produção de Brasil Intercultura foi desenvolvida de maneira independente pela Casa do Brasil e em breve estará à venda a nova edição de todos os volumes. A Casa do Brasil, conforme relatado anteriormente, ciente da necessidade de mudar a filosofia de ensino, contratou a especialista Edleise Mendes para organizar e coordenar um Workshop com professores, coordenadores e diretores da escola, para definir os princípios que adotariam para definir o currículo e planejamento dos cursos da instituição e seus respectivos materiais didáticos.

\subsubsection{HORIZONTES: Rumo à Proficiência em língua portuguesa}

"Horizontes" foi lançado oficialmente em Buenos Aires no dia 19 de Março de 2010 na Casa do Brasil em Buenos Aires. O livro esteve à venda em várias livrarias do país e na franquia internacional especializada em idiomas SBS. Infelizmente, por motivos que se desconhecem esse material foi retirado do mercado, apesar de ainda ser utilizado pelo "Instituto Horizonte Brasil: cursos de português e cultura brasileira" no curso "Nível de Proficiência". Na apresentação, o livro é recomendado pela diretora do 
Instituto Horizonte, e autora do exemplar, Adriana Almeida, para alunos que queiram aperfeiçoar seus conhecimentos básicos, intermediários e avançados adquiridos em cursos de português. A única edição de Horizontes compõe-se de um livro do aluno e um CD de áudio. Trata-se de uma produção da editora LiBreAR sob a consultoria pedagógica de Laura Marcato, da autoria de Adriana Almeida e Cibele Nascimento Barbosa, também co-autora do primeiro volume da Coleção Brasil Intercultural.

Quanto à primeira autora do material, Adriana Almeida, ela é formada em Letras pela Faculdade de Filosofia, Letras e Ciências Humanas de São Paulo (1992) e mestranda em História da Arte pela Universidade de San Martin (IDAES - Buenos Aires, Argentina). Desde 1997, dedica-se ao ensino de português como língua estrangeira para hispanofalantes. Em 2003, especializou-se no ensino dessa língua para estrangeiros pela PUC-RJ (especialização latu-sensu) e, em 2005, em Cultura Brasileira pela Universidade de San Andrés (Buenos Aires- Argentina). Também é co-autora do livro didático "Um português bem brasileiro" da FUNCEB (atual CCBA, Buenos Aires). Atualmente Adriana Almeida é a diretora do Instituo Horizontes antes mencionado. Infelizmente não consegui nenhuma informação sobre a consultora pedagógica da produção, Laura Marcato.

Verifica-se que as duas autoras tiveram alguma ligação com a Casa do Brasil e, de fato, em ambos os materiais didáticos, na sua apresentação, os autores declaram estar filiados à abordagem intercultural. A seguir, entrarei em detalhes na análise das características de abordagem dos dois livros didáticos apresentados.

\subsubsection{Critérios para seleção dos livros}

No capítulo II, Fundamentação teórica, mostrei duas tabelas de livros didáticos elaborados dentro e fora do Brasil. Alguns deles não estão mais à venda e outros são produções bem recentes. Os critérios que definiram quais seriam os LDs analisados foram:

1- O caso escolhido: a produção argentina de materiais didáticos para o ensino de PLE.

2- Livros de produção independente: ambos os livros foram elaborados por professores e especialistas da área de PLE associados a duas instituições de ensino dessa língua na Argentina. Nenhum dos dois títulos pertence a uma 
editora de grande tiragem como acontece com a maioria de livros de ensino de línguas estrangeiras disponíveis no mercado.

3- Abordagem comunicativa: em ambos os livros seus autores declaram haver utilizado os princípios da abordagem intercultural para a elaboração dos mesmos. Como não considero haver uma abordagem intercultural independente, pressuponho que haja a expectativa de que essa seja um matiz da AC.

Ainda que o livro "Horizontes" não esteja mais à venda nas livrarias argentinas, ele foi escolhido para análise porque se trata de um material atualmente usado nas aulas do curso "Nível de Proficiência" do Instituto Horizontes, escola de PLE na Argentina. Além disso, em 2012 e 2013 (ARGENTINA, 2013) esse livro fez parte da bibliografia obrigatória do programa "Lenguas en los barrios” (Línguas nos bairros) para o ensino de "Português - Nível 4" organizado pela Direção de Línguas Estrangeiras do Ministério de Educação do Governo da Cidade de Buenos Aires. Lenguas en los Barrios é um programa de cursos de idiomas aberto à comunidade em 11 sedes de diferentes bairros portenhos, das quais 6 oferecem o ensino de PLE .

\subsection{QUESTÕES E CATEGORIAS PARA ANÁLISE}

Para poder determinar e descrever as características da abordagem dos LDs selecionados foi necessário, em primeiro lugar, definir os indicadores da abordagem de um MD (categorias para se reconhecer a abordagem de um MD) para, em seguida, criar as questões para a análise de cada um deles. Para essa tarefa, apoiei-me na teoria exposta no capítulo II, Resenha de Bibliografia, especificamente no conceito de abordagem de Almeida Filho (1997), nos princípios e fundamentos teóricos da abordagem gramatical e comunicativa de pesquisadores da subárea da Linguística Aplicada, AElin, como Ellis (1996), Barbirato (1999), Skehan (1996), Prabhu (1988), Littlewood (1981), Widdowson (1978) e Krashen (1982), Breen, Candlin e Waters (1999). Segue um quadro desses indicadores com as respectivas questões e taxonomias criadas a partir da análise e da bibliografia disponível: 
Quadro 1 - Resumo de indicadores de um MD com questões e categorias para análise de abordagem

\begin{tabular}{|c|c|c|c|c|c|}
\hline Indicadores & Questões para análise & & Cate & orias e subcategorias & \\
\hline UNIDADES & $\begin{array}{c}\text { Qual é o princípio organizador das } \\
\text { unidades? }\end{array}$ & $\begin{array}{l}\text { Tópicos e } \\
\text { temas }\end{array}$ & $\begin{array}{c}\text { Conteúdos das grandes áreas do } \\
\text { conhecimento }\end{array}$ & Funções comunicativas & $\begin{array}{l}\text { Temas de gramática, } \\
\text { vocabulário e fonética. }\end{array}$ \\
\hline \multirow{11}{*}{ ATIVIDADES } & \multirow{11}{*}{$\begin{array}{l}\text { Que tipo de atividades o material } \\
\text { oferece? }\end{array}$} & \multirow{9}{*}{ TAREFAS } & $\underline{\text { Comunicativas }}$ & Pré-Comunicativas & $\begin{array}{l}\frac{\text { De prática do código }}{\text { linguístico }} \\
\frac{\text { (fonética, gramática, }}{\text { vocabulário) }}\end{array}$ \\
\hline & & & 1- $\quad$ De interação social: & Questionários de opinião & \multirow[b]{2}{*}{ Preenchimento de lacunas } \\
\hline & & & a- Compartilhar e contar & $\begin{array}{l}\text { Interpretação de } \\
\text { áudio/texto/vídeo }\end{array}$ & \\
\hline & & & b- Lacuna de opinião & $\begin{array}{l}\text { Busca e reprodução de } \\
\text { informação }\end{array}$ & Classificação de informação \\
\hline & & & $\begin{array}{l}\text { c- Desempenho de papéis: 1- } \\
\text { debates/discussão, 2- controlado } \\
\text { por meio de pistas ou } \\
\text { informações, 3- controlado por } \\
\text { meio da situação e de objetivos. }\end{array}$ & $\begin{array}{l}\text { Troca de informação } \\
\text { (Lacunas de informação) }\end{array}$ & Automatização por repetição \\
\hline & & & $\begin{array}{l}\text { 2- Troca de informação: } \\
\text { Lacuna de informação }\end{array}$ & \multirow{6}{*}{$\begin{array}{l}\text { c- Desempenho de papéis: } 1 \text { - } \\
\text { debates/discussão, } 2 \text { - controlado } \\
\text { por meio de pistas ou } \\
\text { informações, 3- controlado por } \\
\text { meio da situação e de objetivos. }\end{array}$} & \multirow[t]{2}{*}{ Imitação } \\
\hline & & & 3- Cognitivas: & & \\
\hline & & & \multirow{2}{*}{$\begin{array}{c}\text { a- } \\
\text { L- } \\
\text { Lesoluna de raciocínio, } \\
\text { C- Operações/transformações }\end{array}$} & & Relacionar colunas/fotos \\
\hline & & & & & \multirow{3}{*}{ Seleção de informação } \\
\hline & & & Jogos & & \\
\hline & & & Projetos & & \\
\hline INSUMO & $\begin{array}{l}\text { Como é o insumo do material? De } \\
\text { qualidade e em boa quantidade? Quais } \\
\text { são as fontes dos textos? }\end{array}$ & \multicolumn{3}{|c|}{$\begin{array}{c}\text { Autêntico } \\
\text { Quantidade } x \text { Qualidade } \\
\text { Fontes }\end{array}$} & $\begin{array}{c}\text { Fictício } \\
\text { Quantidade } x \text { Qualidade } \\
\text { Fontes }\end{array}$ \\
\hline
\end{tabular}

Fonte: Elaborado pela autora 
Cabe destacar que pensei no indicador "Formação de aprendizes" (ALMEIDA FILHO 2013, mimeo), para me referir à teoria adaptada para alunos sobre estratégias de ensino e aprendizagem de línguas. Almeida Filho (2013, mimeo) defende a necessidade de que os aprendentes de línguas estrangeiras recebam recomendações dos vários procedimentos que esses podem adotar para aperfeiçoar suas competências de adquirir e aprender línguas. Um roteiro reflexivo sobre o processo de aprendizagem da nova língua poderia ser repassado aos alunos para elevar o nível de consciência deles [...] acerca dos processos que vivem para a apropriação da nova língua (ALMEIDA FILHO, 2013, p. 7). Nesse roteiro, o autor (op. cit.) propõe tópicos sobre estratégias de aprendizagem, autonomia, aspectos afetivos, história e tradição de aprendizagem de línguas para o aluno refletir, papéis e atitudes do aluno frente ao aprendizado, com os colegas e com o professor.

Esses tópicos propostos pelo autor (op. cit.) destacam [...] aspectos do processo adquiridor tratados teoricamente na teoria relevante já produzida e disponibilizada em linguagem apropriada ao nível e condições dos aprendentes [...]. Para o autor, teoria desse tipo, com formato de roteiro reflexivo é necessária para promover a formação de aprendizes.

O livro Brasil Intercultural sugeria implicitamente a criação da categoria "Formação de aprendizes. Na primeira unidade desse didático, na página 9, há informação para os alunos sobre técnicas de leitura (Ver Anexo 7, p.161). Não obstante, é a única pagina com informação desse tipo.

Quanto ao Quadro 1, conforme foi exposto no Capítulo 2, Fundamentação Teórica, o artigo de Almeida Filho et al (1991) é uma bibliografia inicial da LA que explicita ao nível de abordagem os pressupostos de ensino/aprendizagem e expectativas subjacentes à preparação e uso do livro didático nacional de LE. Almeida (2011), também é uma bibliografia inicial para análise de abordagem. Na sua tese de doutorado, esse autor analisa como os manuais didáticos da chamada abordagem comunicativa se apropriaram dos quatro pilares de Competência Comunicativa propostos por Hymes. Freitas (2013, p. 63), na sua dissertação de mestrado, delineia a agenda de pesquisa aplicada no Brasil no que se refere, especialmente, ao construto de abordagem e revela que dos oito trabalhos voltados para a abordagem de terceiros, nenhum deles direciona seu foco analítico exclusivamente para o LD. 
A partir desses artigos, da base teórica de todos os autores supracitados e do Guia do PNLD de línguas estrangeiras (ver Anexo 11), selecionei os "indicadores" aos que a maioria dos teóricos faz referência quando teorizam sobre MDs: insumo, atividades, unidades. Para cada um desses indicadores criei questões que permitem descrever objetivamente suas características para situá-los mais em relação de proximidade quanto a uma ou outra abordagem.

Tudo isso quer dizer que, ao considerar as questões para cada indicador, um professor poderá saber se um material didático tem traços característicos da abordagem comunicativa, gramatical, gramatical comunicativizada ou se ainda está em transição, ou seja, tem traços de uma abordagem com concessões para outra, ou se tem traços de abordagens de bases teóricas diferentes, e, a partir disso, adotá-lo ou não. Em função dessa análise, o professor também poderá prever a natureza das adaptações que poderia precisar fazer durante o uso. Enfatizo a aplicação da mencionada grade (Quadro 1, p.84) porque um dos objetivos desta dissertação é desenvolver por meio da análise de abordagem dos MDs de PLE Argentinos um procedimento que possa ser usado por professores de línguas para selecionar/adotar MDs previamente ao uso. Trata-se de uma proposta que não lança mão de uma check list. O quadro 1 é um resumo de questões e indicadores que compõem o procedimento de análise aqui proposto.

Para Almeida Filho (1993, p. 40), no Brasil [...] é preciso recuperar a capacidade de avaliar o material que se candidata nas prateleiras a substituir o verdadeiro planejamento de cursos fundamentado no processo único de prover materiais para cada situação de ensino. Com esse fim, o autor propõe a criação de projetos regionais duradouros, de longo alcance, com o acompanhamento de especialistas da área da Linguística Aplicada e Ensino de Línguas.

A grade de questões e categorias resume o procedimento de análise ao qual submeti os MDs. A ordem dos indicadores não representa nenhuma hierarquia. A leitura deve ser feita de maneira horizontal atendendo as bordas grossas que separam os indicadores com suas respectivas questões, categorias e subcategorias e as bordas finas que separam as categorias das subcategorias. Quanto mais à direita se concentrem as respostas nas categorias e subcategorias, significa que os materiais têm mais traços característicos da abordagem comunicativa e quanto mais à esquerda estiverem, mais poderiam indicar estar filiados à abordagem gramatical, e podem ficar também em estágio de "transição". 


\subsection{ANÁLISE DOS MATERIAS DIDÁTICOS SELECIONADOS}

No Capítulo II desta dissertação, apresentei os traços característicos dos indicadores constitutivos da abordagem gramatical (Tabela 6, p. 61) e comunicativa (Tabela 7, p. 66). Esses traços deram origem às categorias e subcategorias apresentadas na seção anterior que foram usadas para analisar e definir as características de abordagem dos materiais selecionados. Por tanto, nesta seção é necessário retomar a literatura apresentada no capítulo 2 e aprofundá-la. Segue a análise dos LDs Brasil Intercultural e Horizontes.

Cabe destacar, que, além disso, neste capítulo vou responder e retomar os questionamentos guia deste trabalho de pesquisa explicitados na introdução:

\section{1- Qual é a abordagem predominante nos MDs de PLE produzidos na Argentina? \\ a- Quais traços da abordagem comunicativa e quais da abordagem gramatical esses materiais guardam?}

\subsubsection{Análise de Brasil Intercultural - Ciclo Básico: livro do aluno}

\section{Unidades}

Definir unidades de ensino e aprendizagem de uma LE é uma das tarefas da primeira materialidade do modelo OGEL, planejamento de cursos. A proposta de unidades deve incluir: a) um formato de unidade de estudo, b) os objetivos, c)as possíveis competências-alvo, d) coesão interunidades (o que dará coesão ao conjunto de unidades), e) [...] a natureza das experiências que serão promovidas nas unidades e f) os conteúdos que estão implícitos nessas experiências [...] (ALMEIDA FILHO, 2012, p. 50, grifo meu). Para o autor, todas essas variáveis, inclusive a estética, podem ser pensadas em função dos materiais didáticos a serem produzidos ou escolhidos para o curso.

O planejador estrutura o plano de unidades que fará parte do curso em função do seu conhecimento prévio sobre o contexto no qual se insere a situação de ensino e dos pressupostos sobre o que é linguagem (língua, linguagem humana, língua 
estrangeira), aprender e ensinar línguas, ou seja, em função de sua abordagem. Esse conhecimento prévio e pressupostos (a abordagem) formam [...] um composto de ideias ou conceitos que orienta e, portanto, caracteriza todo um processo específico de ensino de língua [...] (ALMEIDA FILHO, 2012, p.41), ou seja, ainda que o planejamento seja a primeira materialidade da Operação Global de Ensino de línguas, o mesmo autor afirma (op. cit.), ele não é exatamente o início dessa grande operação.

Todas as materialidades têm como força motriz uma dada abordagem e dela depende a configuração de todas as materialidades. No caso do currículo do curso, para Almeida Filho (2012, p. 33), o planejador [...] elabora o planejamento de unidades que vai servir de base para a produção ou seleção de material-insumo com o qual alimentar o processo de ensino aprendizagem [...] sob a influência desses pressupostos (concepções de linguagem, aprender e ensinar uma LE) e do conhecimento prévio do contexto de ensino. A abordagem é o sustento e explicação de toda a natureza das experiências de ensino e aprendizagem da grande OGEL. Pode-se iniciar pela produção do LD ou por sua adoção. Nesse caso um planejamento estará pressuposto.

Assim, para definir qual é o princípio organizador das unidades dos materiais didáticos selecionados para análise, observei principalmente a natureza dos conteúdos que dão coesão às unidades, interunidades e às experiências promovidas nas mesmas. Usei como referente para definir as categorias de análise do indicador constitutivo "unidades" as características das duas macro abordagens, estrutural (gramatical) e comunicativa, reconhecidas respectivamente no capítulo II (Tabela 6, p. 61 e Tabela 7, p.66) deste trabalho de dissertação e os esquemas explicitados a seguir:

Figura 7 - Esquema processual básico de organização das unidades no planejamento comunicativo

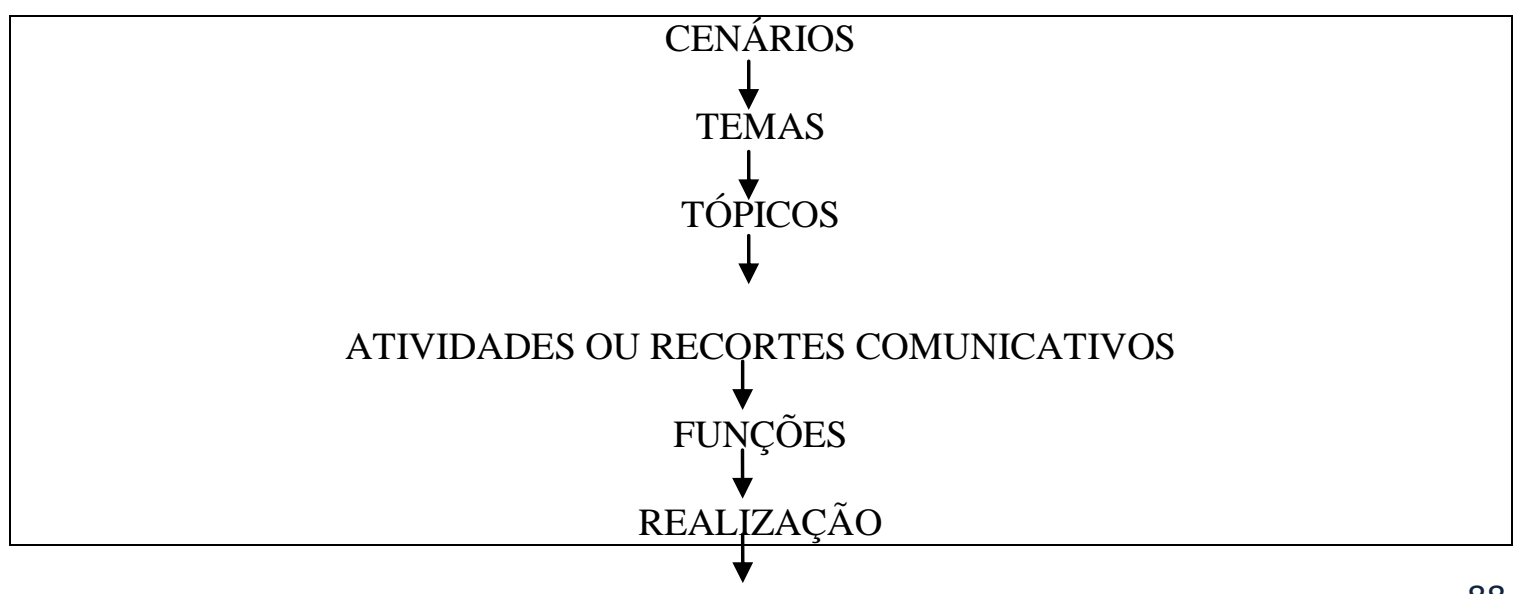


Fonte: ALMEIDA FILHO (2012, p. 51)

O autor (op.cit) explica que para um planejamento de natureza comunicativa é possível planejar o desenvolvimento das unidades em torno de um tema maior, um tema ficcional ou de uma disciplina.

Além disso, o mesmo autor (op.cit) se refere a tipos de planejamentos que condizem com determinada abordagem ao asseverar que, por exemplo, o planejamento linear de unidades remete a abordagem gramatical por representar a progressão de um item linguístico de aprendizagem para outro. As unidades avançam isolando conteúdos/segmentos linguísticos. Por outro lado, para o autor (op. cit.) o planejamento cíclico, tem características semelhantes ao linear, mas diferentemente desse, o cíclico implica uma volta ao conjunto inicial de segmentos e funções linguísticas préselecionadas de maneira que se possa expandi-las cada vez que forem retomadas em ciclos posteriores.

$\mathrm{O}$ autor ainda afirma que esses dois tipos de planejamentos (que dão origem à seleção e/ou produção de materiais didáticos) transparecem o conceito de ensino e aprendizagem de línguas como um esforço por ensinar e aprender a língua pela língua, ou seja, ensinar "sobre a língua" (regras gramaticais e socioculturais, funções comunicativas). Isso coincide com uma visão (abordagem) sistêmica, estrutural gramatical da concepção de língua, linguagem, aprender e ensinar uma língua. Decorrente dessa apreciação, o autor (ALMEIDA FILHO, 2012, p. 47) afirma que os pressupostos que dão origem a esses dois tipos de planejamentos não consideram

[...] a visão alternativa de se tomar a experiência de aprender línguas como parte de uma experiência maior de aprender outras coisas como, por exemplo, os conhecimentos de outras disciplinas como ciência, história, artes, etc.

Com isso, é possível arriscar o seguinte quadro para reconhecer a natureza dos conteúdos das unidades que somadas às características da totalidade dos indicadores constitutivos da abordagem de um MD, permitirão definir as características de abordagem dos materiais selecionados para análise na pesquisa aqui relatada: 
Quadro 2 - Princípios organizadores das unidades de um MD

\begin{tabular}{|c|c|}
\hline \multicolumn{2}{|c|}{ Natureza dos conteúdos das unidades } \\
\hline Abordagem estrutural & Abordagem comunicativa \\
\hline - Tópicos do código linguístico (tópicos & - Tópicos de interesse dos alunos \\
sobre o sistema formal da língua): & - Tópicos e temas \\
gramática, fonética, vocabulário, aspectos & - Conteúdos das grandes áreas do conhecimento: \\
socioculturais . & geografia, história, política, matemática, \\
(Stern 1989, Sateles \& Almeida Filho, & tecnologia... \\
2010) & - Recortes comunicativos, funções comunicativas \\
& (Littlewood 1986, Almeida Filho 2012, Barbirato \\
& 1999 ) \\
\hline
\end{tabular}

Fonte: Elaborado pela autora

O livro do aluno "Brasil Intercultural" do Ciclo Básico divide-se em 8 unidades. O Nível 1, composto pelas 4 primeiras unidades e o Nível 2 pelas 4 restantes: 0- Conhecendo o Brasil, 1- Interagindo em português, 2-Quebrando a Rotina, 3Descobrindo o mundo, 4- Infância 5- Sonho de consumo, 6- Notoriedade, 7- Túnel do tempo. Ao lançar um olhar analítico quanto à abordagem do material, é possível perceber que os princípios organizadores da maioria das unidades são funções comunicativas e tópicos de gramática, vocabulário e fonética. Ainda que os nomes de algumas unidades sugiram temas, e o ensino temático seja um dos princípios organizadores das experiências do ensinar e aprender uma LE na Abordagem Comunicativa (AC), se o tema é dado para articular prioritariamente o uso de certas estruturas e vocabulário, o foco das unidades é o código linguístico e não um tema propriamente dito. Não obstante, quando as unidades estão organizadas por meio de tópicos, como "Infância", por exemplo, é esse tópico que norteia as oportunidades/unidades de ação/comunicação na LE, o aprendizado dos temas, e como consequência, no andamento, a sistematização, o conhecimento do código (ALMEIDA FILHO, 1993).

O gráfico a seguir ilustra o resultado da análise acima: 


\section{Gráfico 1- Princípios organizadores das unidades}

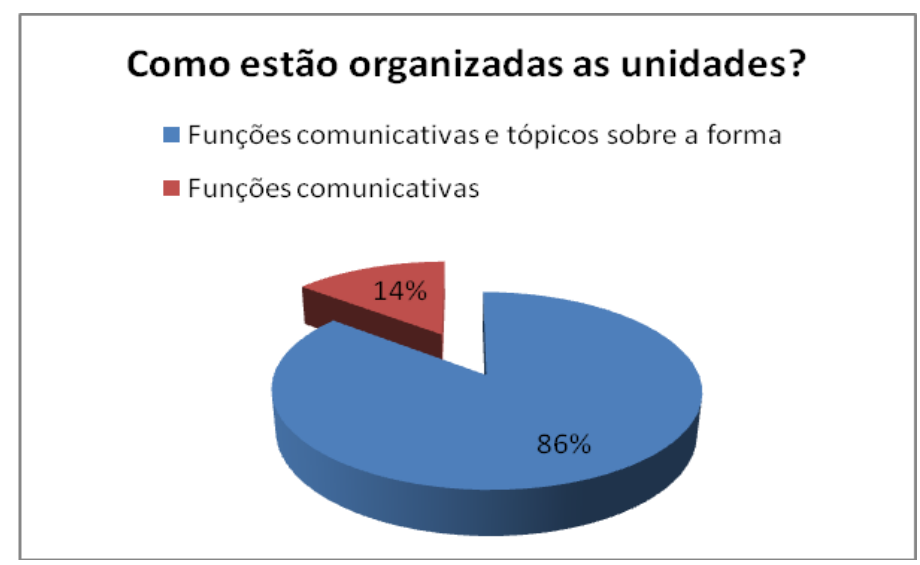

A natureza dos conteúdos pré-selecionados para as unidades é sistêmica, pois de maneira linear são apresentados em cada unidade tópicos e funções sobre a língua que articulam a maioria das experiências propostas para aprender a LE. Conforme ilustrado no gráfico, $14 \%$ das unidades do livro do aluno tem conteúdos préselecionados sobre funções comunicativas e o restante $86 \%$ os conteúdos préestabelecidos são funções comunicativas e tópicos de gramática, vocabulário, fonética e regras socioculturais (tópicos sobre a forma).

A partir desses dados, é possível inferir que o tipo de planejamento de curso implícito no material é linear, pois cada unidade prioriza o ensino e uso de certas estruturas gramaticais, gêneros textuais e vocabulário por meio de um tópico que prioritariamente promove o ensino preventivo de determinadas estruturas e vocabulário e não a aprendizagem do tópico na língua estrangeira como uma experiência cognitiva maior [...] de aprender outras coisas como, por exemplo, os conhecimentos das outras disciplinas como ciência, história, artes, etc. [...] (ALMEIDA FILHO, 2012, p.47). Na unidade 2, Quebrando a Rotina, por exemplo, o tópico não remete a temas sobre maneiras de tornar a rotina menos pesada, repetitiva, etc., mas à introdução dos verbos do presente do indicativo relacionados à rotina, dias da semana, meses e estações do ano... Esses tópicos linguísticos não emanam do insumo, mas são preventivamente programados por meio de insumo que propositalmente trazem esses tópicos. Cabe salientar que no sumário do livro é possível identificar os conteúdos linguísticos preventivamente programados de maneira linear e explicitados nas fichas de teoria de cada unidade. 


\section{Atividades}

Em função da necessidade de analisar a natureza das atividades (que tipo de atividades o material oferece?) propostas no livro do aluno, foi necessário verificar na teoria da área quais princípios para a construção de atividades nucleiam-se ao redor de cada uma das macroabordagens explicitadas na fundamentação teórica. Assim, em função da teoria consultada surgiu o seguinte quadro:

\section{Quadro 3 - Princípios de configuração de atividades}

\begin{tabular}{|c|c|}
\hline \multicolumn{2}{|c|}{ Natureza das atividades } \\
\hline Abordagem estrutural & Abordagem comunicativa \\
\hline - Foco: na forma com exercícios que & - Foco: no significado com atividades que \\
priorizam a prática do código linguístico & promovem negociação e interação para sua \\
por meio da repetição de padrões, & resolução. \\
imitação, preenchimento de lacunas, etc. & - Ponto de partida: um tópico, um tema \\
-Ponto de partida: um tópico "sobre" a & contemporâneo, das grandes áreas do \\
língua. & conhecimento. \\
\hline
\end{tabular}

Fonte: Elaborado pela autora

Segundo o Glossário de Linguística Aplicada (GLOSSA, www.glossario.sala.org.br/) uma atividade é uma "Unidade de ação no método de ensino e aprendizagem de línguas, realizada com o intuito de praticar ou usar uma língua-alvo em sala, ou outros lugares. No ensino de línguas, essas ações denominadas atividades se destinam a fazer compreender o funcionamento da nova língua ou experienciar o uso efetivo dela visando com isso o desenvolvimento de uma competência comunicativa na língua-alvo.”. A partir dessa definição é possível enxergar dois tipos de atividades para ensino e aprendizagem de uma língua: a) comunicativas (orientadas pela mensagem), e b) atividades de prática linguística (orientadas pelo código).

Stern (1992, p. 177) faz essa distinção. Para o autor usa-se o termo atividades comunicativas para designar [...] atividades motivadas, tópicos e temas que envolvem o aprendente em comunicação autêntica" ${ }^{4}$. Nesse tipo de atividades, o autor prossegue

${ }^{4}[\ldots]$ motivated activities, topics, and themes which involve the learner in authentic communication. 
(op. cit.), o foco é nas atividades, no tópico ou nas experiências e não em algum aspecto da língua. Stern (op. cit.) afirma que as atividades orientadas pela mensagem (comunicativas) podem ser classificadas em: conversas, tarefas, problemas, projetos. Por exemplo, prossegue Stern (op. cit., grifo meu)

\begin{abstract}
Pode ser um episódio curto durante uma aula, não precisa ser um projeto complexo. Assim, se durante a aula o professor pede ao aluno para abrir a janela, essa interação toma-se uma atividade comunicativa se as circunstâncias genuinamente garantem o pedido. No entanto, se o professor pede para o aluno abrir a janela, se o propósito da frase é praticar como fazer pedidos, usando a forma imperativa, trata-se de um exercício linguístico dentro do planejamento de cursos e não de uma atividade comunicativa em seu próprio sentido ${ }^{5}$.
\end{abstract}

A partir desse exemplo dado pelo autor (op. cit.) depreende-se que uma atividade orientada pelo código (atividades de prática linguística) envolve a prática funcional e gramatical da língua, ou seja, tem foco na forma e não na construção de sentido.

O mesmo autor (STERN, 1992, p.178) ainda esclarece que as atividades comunicativas não se restringem apenas a conversas em sala de aula. Elas podem extrapolar as paredes da sala, do ensino formal, por exemplo, planejar uma viagem escolar no contexto da aula de LE: a preparação e a viagem em si envolvem muitas atividades comunicativas. Ainda que essa atividade possa ser planejada para fornecer oportunidades de prática linguística (prática do código), ela exige uso linguístico real, no planejamento conjunto da viagem para reunir informação sobre lugares para visitar, no financiamento da viagem, no contato com famílias e escolas e na reserva de hospedagem. Esse tipo de atividades propicia aos alunos uma situação da vida "real" na qual a língua-alvo deve ser usada. Para Stern (op. cit.) isso é uma atividade comunicativa por excelência. A natureza da atividade (foco) não é a linguagem, mas o uso da língua-alvo segundo as exigências das circunstâncias.

Nas atividades de prática do código linguístico, o foco está em aprender formas específicas do sistema da língua. Nessa categoria, encontram-se os exercícios, definidos

\footnotetext{
${ }^{5}$ It may be a short episode in a language class: it does not have to be a complex project. Thus if in a language class, the teacher asks a student to open the window, this exchange becomes a communicative activity if the circumstances' genuinely warrant the request. But if the purpose of the utterance is to practice making requests using the imperative form, it is a linguistic exercise within the language syllabus and not a communicative activity in our sense.
} 
pelo Glossário de Linguística Aplicada (GLOSSA) como uma "Categoria de atividade curta conduzida em classe pela professora como prática de língua nas salas, mas também nas extensões pelos aprendentes sozinhos, com foco na forma da língua e no vocabulário mediante emprego de regras em transformações, preenchimento de lacunas, imitação de modelos e automatização por repetições”. Stern (1992, p. 178) também exemplifica esse tipo de atividades:

[...] se o professor perguntar ao aluno se ele tem irmãos ou irmãs e acrescenta, "responda negativamente", a pergunta é designada para fornecer prática de um ponto gramatical. Não se trata de uma pergunta com valor comunicativo, uma vez que o professor não está interessado na família do aluno ${ }^{6}$.

Esses princípios permitiram identificar durante a análise diferentes classificações de atividades nucleadas a uma ou outra abordagem. Em função disso, defini a seguinte taxonomia para identificar o tipo de atividades presentes em um material didático de língua estrangeira:

\footnotetext{
${ }^{6}[\ldots .$.$] if the teacher ask a student whether he has brothers or sisters and adds "Answer in the negative",$ the question is designed to provide practice of a point of Grammar. It is not a question of any communicative value, since the teacher did not ask out of the interest in the student's family background.
} 
Quadro 4- Taxonomia para identificação do tipo de atividades de um MD

Taxonomia para classificação de atividades

\begin{tabular}{|c|c|c|}
\hline$\frac{\text { Comunicativas }}{\text { (Tarefas) }}$ & Pré-Comunicativas & $\frac{\text { De prática do código linguístico }}{(\text { fonética, gramática, vocabulário) }}$ \\
\hline 1- $\quad$ De interação social: & Questionários de opinião & \multirow[b]{2}{*}{ Preenchimento de lacunas } \\
\hline a- Compartilhar e contar & $\begin{array}{l}\text { Interpretação de } \\
\text { áudio/texto/vídeo }\end{array}$ & \\
\hline b- Lacuna de opinião & $\begin{array}{l}\text { Busca e reprodução de } \\
\text { informação }\end{array}$ & Classificação de informação \\
\hline $\begin{array}{l}\text { c- Desempenho de papéis: 1- } \\
\text { debates/discussão, } 2 \text { - controlado por } \\
\text { meio de pistas ou informações, } 3 \text { - } \\
\text { controlado por meio da situação e de } \\
\text { objetivos. }\end{array}$ & $\begin{array}{l}\text { Troca de informação } \\
\text { (Lacunas de informação) }\end{array}$ & Automatização por repetição \\
\hline $\begin{array}{l}\text { 2- } \quad \text { Troca de informação: } \\
\text { Lacuna de informação }\end{array}$ & \multirow{6}{*}{$\begin{array}{l}\text { c- Desempenho de papéis: } 1 \text { - } \\
\text { debates/discussão, 2- } \\
\text { controlado por meio de pistas } \\
\text { ou informações, } 3 \text { - } \\
\text { controlado por meio da } \\
\text { situação e de objetivos. }\end{array}$} & \multirow[t]{2}{*}{ Imitação } \\
\hline 3- Cognitivas: & & \\
\hline $\begin{array}{c}\text { a- } \begin{array}{c}\text { Lacuna de raciocínio, } \\
\text { b- }\end{array} \text { Resolução de problemas }\end{array}$ & & Relacionar colunas/fotos \\
\hline C- Operações/transformações & & \multirow[t]{3}{*}{ Seleção de informação } \\
\hline Projetos & & \\
\hline Jogos & & \\
\hline
\end{tabular}

Fonte: elaborado pela autora a partir de Barbirato (1999), Almeida Filho (2012), Breen, Candlin e Waters (1998)

No caso do livro do aluno "Brasil Intercultural", ainda que as unidades tragam temas que promovam majoritariamente a prática de certas estruturas e vocabulário, uma análise minuciosa permite identificar atividades que não são exercícios, mas que ainda estão vinculadas à prática de algum tópico da forma, e atividades comunicativas também. Essas atividades com atenção à forma sem necessariamente se tratar de exercícios são denominadas por Barbirato (1999) como "pré-comunicativas".

Segundo essa autora (1999, p.102), pré-comunicativas são as atividades ainda mais relacionadas à forma do que ao significado, embora não sejam essencialmente mecânicas (exercícios); elas preparam para atividades futuras mais livres, voltadas para o uso da língua. Para Littlewood (1986), esse tipo de atividades tem como objetivo principal produzir formas linguísticas de maneira aceitável e não comunicar significados. Assim, entre as atividades identificadas nas unidades com essas características, pré-comunicativas, estão: a- Interpretação de texto com opinião, b- 
Interpretação de áudio e vídeo, c- Questionários de opinião, d- Busca e reprodução de informação, e-Troca de informação, f- Produção de Gêneros textuais e g- Desempenho de papéis.

Os nomes dessa categoria de atividade parecem retratar oportunidades de comunicação genuínas. Não obstante, elas seguem padrões tradicionais de perguntaresposta e produção escrita/oral direcionada ao uso de determinados conteúdos linguísticos. A Figura 8 mostra uma atividade de produção de gênero textual précomunicativa, pois o foco da atividade é o uso do Futuro Imediato, preventivamente apresentado em insumo e teoria na página 44 da mesma unidade do livro (Unidade 2Quebrando a rotina) e ainda que na vida real façamos listas de objetivos, não estamos com a atenção voltada para a forma verbal usada na lista, mas para os objetivos em si a serem listados:

Figura 8- Atividade pré-comunicativa: produção de gênero textual (Lista)

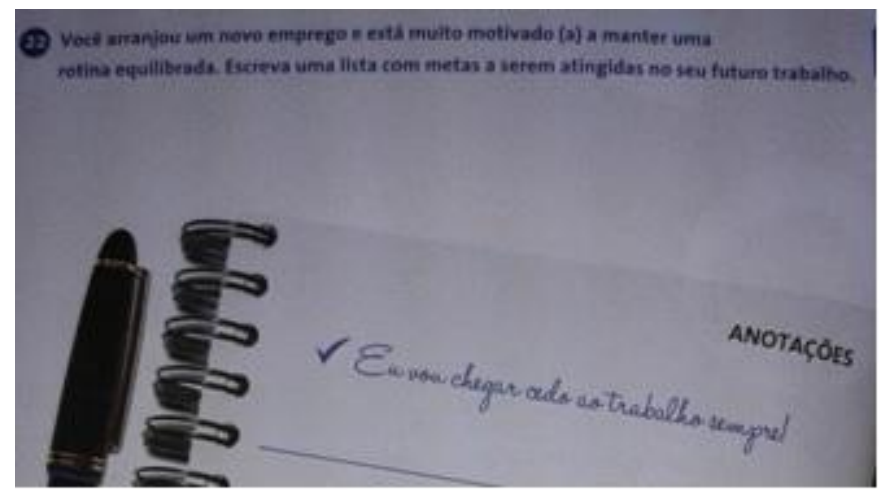

22-Você arranjou um novo emprego e está muito motivado(a) a manter uma rotina equilibrada. Escreva uma lista com metas a serem atingidas no seu futuro trabalho.

Fonte: Brasil Intercultural - Ciclo Básico (p.50)

Conforme afirmado anteriormente, o livro também apresenta atividades comunicativas (ainda que em porcentagem mínima), ou seja, atividades cujo objetivo principal é produzir significados, envolver os alunos em comunicação real, como na resolução de um problema, um jogo, uma tarefa ou a criação e execução de um projeto (STERN, 1992). As páginas 86, 102, e 125, das unidades 5, 6 e 7 respectivamente, apresentam atividades que estão mais próximas de tarefas comunicativas de interação social como desempenhar papéis (debate) e compartilhar e contar. E na página 76 há um jogo de adivinhação. A seguir, na Figura 9 retrata-se uma dessas atividades: 


\section{Figura 9 - Atividade Comunicativa - Desempenho de papéis (Debate)}

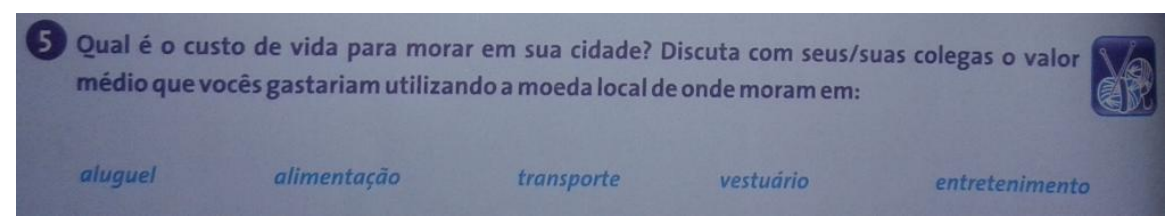

Qual é o custo de vida para morar em sua cidade. Discuta com seus/suas colegas o valor médio que vocês gastariam utilizando a moeda local de onde moram em: aluguel, alimentação, transporte, vestuário e entretenimento.

Fonte: Brasil Intercultural - Ciclo Básico (p.86)

Além de um número significativo de atividades pré-comunicativas, o livro apresenta uma quantidade semelhante (embora menor) de atividades de prática do código linguístico, como exercícios de preenchimento de lacunas com verbos e vocabulário, substituição, seleção e classificação de informação, todas voltadas ao treino de conjugação de verbos, fixação de vocabulário e classificação de sons do português apresentados na teoria sobre o código em cada unidade e no apêndice gramatical.

Os gráficos a seguir ilustram e ampliam o resultado dessa análise:

\section{Gráfico 2 - Natureza das atividades}

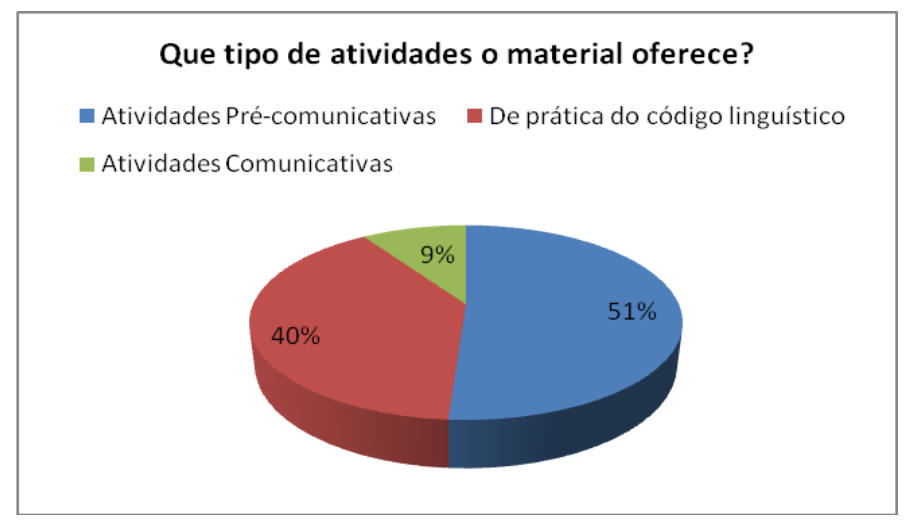

Como visto, apenas $9 \%$ das atividades do material estão voltadas exclusivamente para a construção do significado (atividades comunicativas). Dessas, $51 \%$ promovem majoritariamente o uso de certas estruturas e vocabulário para sua realização (pré-comunicativas) e, em número não menor, $40 \%$ correspondem a atividades cujo ponto de partida é a prática da forma, do código, de estruturas, vocabulário, fonética, entre outros. 


\section{Gráfico 3 - Classificação das Atividades Pré-comunicativas}

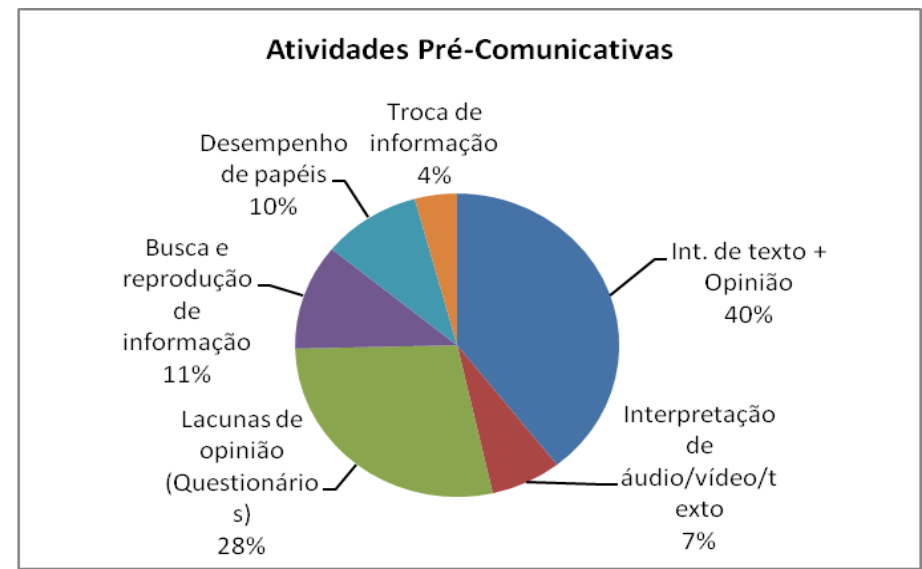

A tipologia de atividades comunicativas de Barbirato (1999, ver Anexo 5, p. 155) foi fundamental para classificar de maneira minuciosa as atividades propostas no MD, pois essa tipologia é útil para identificar tanto atividades pré-comunicativas quanto comunicativas sendo que o fator determinante para "agrupá-las" em uma ou outra categoria é o ponto de partida (a natureza) de cada uma delas. As pré-comunicativas são atividades que ainda promovem o uso de determinadas formas, estruturas e vocabulário, dão os trilhos de maneira preventiva que o aluno deve seguir para resolver a atividade (ver exemplo Figura 10), são atividades em transição entre a prática da forma e a construção do significado.

Como já afirmou Stern (1992), com uma natureza centrada na construção e negociação do significado por meio da interação, as atividades comunicativas têm como ponto de partida a própria atividade, a resolução de um problema (PRABHU, 1987), um tema, um tópico e não um aspecto da língua-alvo. Assim, uma atividade de desempenho de papéis pode estar em qualquer uma das classificações de atividades, comunicativas ou pré-comunicativas, o que muda é o foco: respectivamente, em uma a resolução da própria atividade será o ponto de partida, e na outra o uso de determinadas estruturas da língua será a base para se chegar ao resultado esperado.

No livro do aluno "Brasil Intercultural" há grande variedade de Atividades

\section{Pré-comunicativas:}

- Interpretação de texto + Opinião: apresenta-se um texto para ler e logo depois um questionário de sua interpretação do texto, das características linguísticas do gênero, com algumas perguntas de opinião. 


\section{Figura 10 - Exemplo de Atividade Pré-comunicativa "Interpretação de texto + Opinião"}

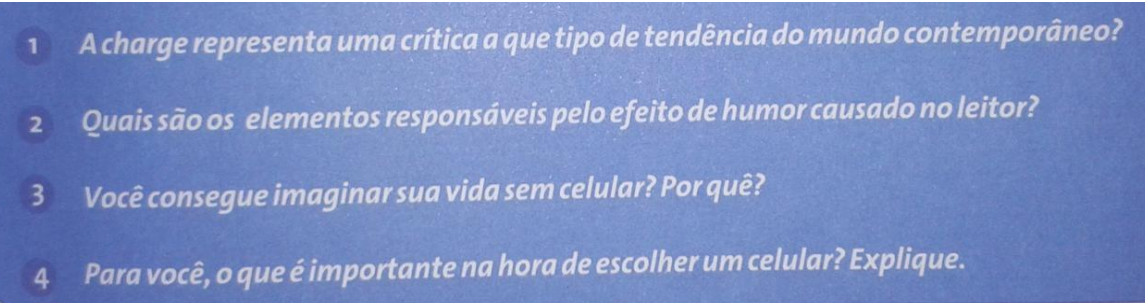

Fonte: Brasil Intercultural (p. 11)

Embora essas atividades constituam em sua maioria a introdução ao tópico central da unidade, elas mantêm o padrão tradicional de "pergunta - resposta" para trabalhar o insumo dado. Segundo Barbirato (1999, p.121), esse padrão responde à tipologia de atividades pré-comunicativas já que o professor pergunta e os alunos respondem. É o professor que "gerencia" a atividade "lançando as perguntas as quais os alunos deveriam responder".

- Questionários de opinião (Lacunas de opinião): trata-se de uma lista de perguntas de opinião sobre um texto previamente dado.

\section{Figura 11 - Exemplo de Atividade Pré-comunicativa "Questionários de Opinião"}

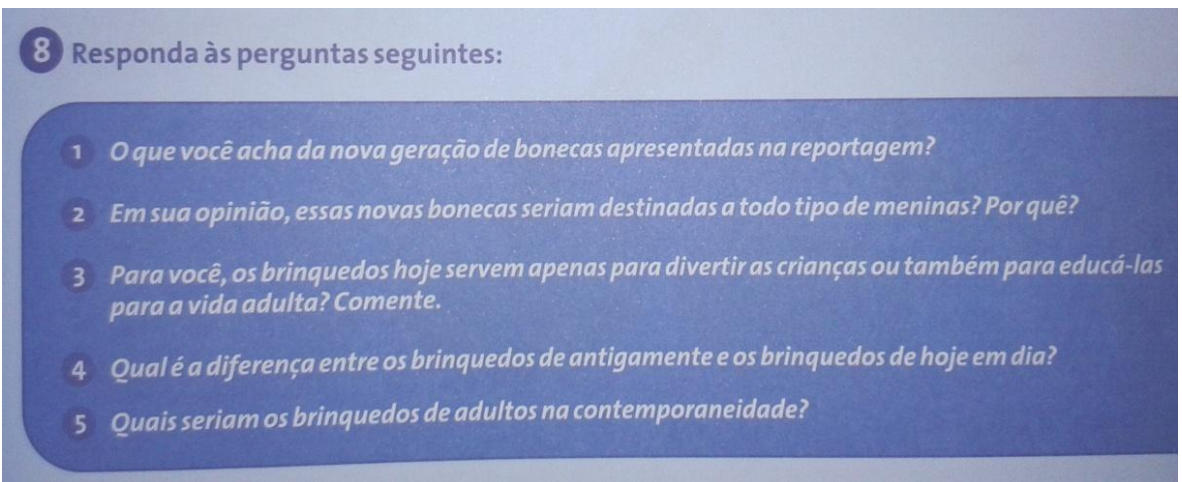

Fonte: Brasil Intercultural (p.75)

Nessa proposta de ação, novamente se repete o padrão tradicional "perguntaresposta". Com isso não quero dizer que não devem existir atividades do tipo em um material didático, ou que essas atividades não são úteis, mas quando predominam, o papel do aluno em sala de aula se reduz a simples respondedor de questionamentos sendo que é possível produzir ação concreta e ter experiências mais produtivas que aumentem as chances de o aprendiz de adquirir a nova língua. 
- Interpretação de áudio/vídeo/texto: um áudio/vídeo ou texto é apresentado para responder posteriormente a um questionário de interpretação sobre as informações do insumo dado.

Figura 12 - Exemplo de Atividade Pré-comunicativa "Interpretação de texto/áudio/vídeo"

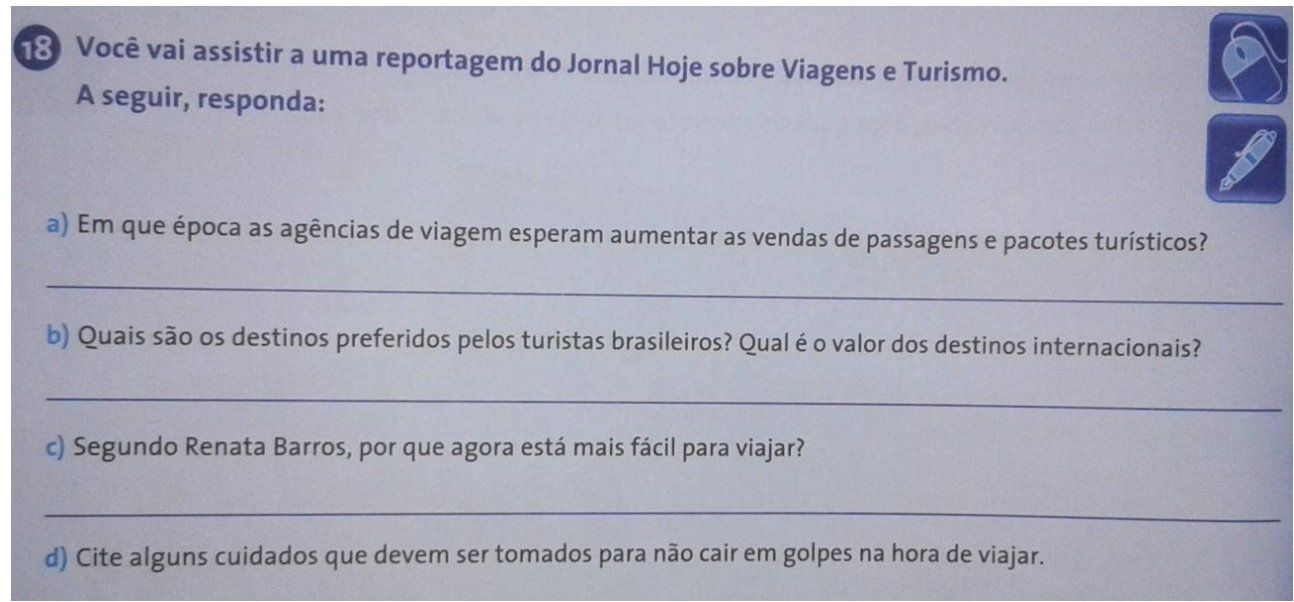

Fonte: Brasil Intercultural (p. 66)

Novamente temos uma atividade com as características de pergunta-resposta, neste caso sobre o insumo dado. As atividades com essa característica do padrão tradicional constituem o $75 \%$ do total de atividades pré-comunicativas de Brasil Intercultural (Interpretação de texto + Opinião 40\%, Interpretação de áudio/vídeo/texto 7\% + Questionários de Opinião 28\%), ou seja, o livro atribui majoritariamente um papel de "Grande autoridade", "Questionador", "Direcionador" (ALMEIDA FILHO, 1997, p.26) ao professor. Isso mostra uma concepção de ensinar mais formalista e tradicional dos autores do livro em análise.

- Busca e reprodução de informação: trata-se de uma atividade que propõe a busca de informação sobre um tema relacionado ao tópico da unidade para posteriormente apresentar aos colegas durante a aula.

Figura 13 - Exemplo de Atividade Pré-comunicativa "Busca e reprodução de informação"

6 Você conhece alguns apelidos brasileiros criados a partir de nomes próprios? Faça uma pesquisa e mostre o resultado para a turma.

Fonte: Brasil Intercultural (p. 16) 
Cabe destacar a banalização do termo "pesquisa" nesta atividade, pois o que realmente é proposto é uma busca seletiva de informação e não uma pesquisa propriamente dita.

- Desempenho de papéis: uma ou várias situações fictícias são dadas para os alunos representarem por meio da interação usando conteúdos linguísticos previamente explicitados. Por exemplo, propõe-se a criação de um diálogo em que um amigo parabeniza outro pelo seu aniversário porque previamente deu-se uma lista de vocabulário sobre essa situação e há que praticar o uso dessas novas palavras. A atividade não pretende a simulação de uma situação de comunicação o mais próxima possível da vida real, mas uma prática de vocabulário do conteúdo preventivo programado na unidade de ensino e explicitado logo antes da proposta de atividade.

Figura 14 - Exemplo de Atividade Pré-comunicativa "Desempenho de papéis"

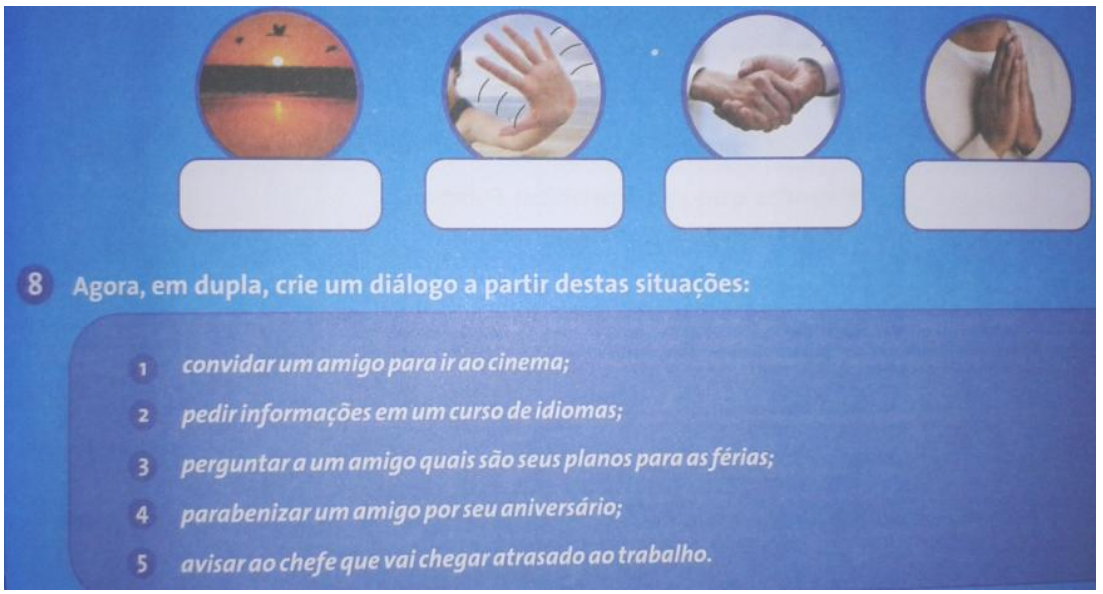

Fonte: Brasil Intercultural (p. 17)

Na mesma página dessa atividade há desenhos com expressões para unir com fotos das mesmas situações, e outras também, que solicitam ser representadas no comando 8 (ver figura 14 acima). Claramente, trata-se de uma atividade que promove o uso de certo vocabulário listado de forma prévia.

- Troca de informação: uma série de perguntas é dada para solicitar informação sobre o tópico da unidade (as férias passadas, por exemplo) a um colega e 
comentar com o grupo as informações obtidas.

\section{Figura 15 - Exemplo de Atividade Pré-comunicativa "Troca de informação"}

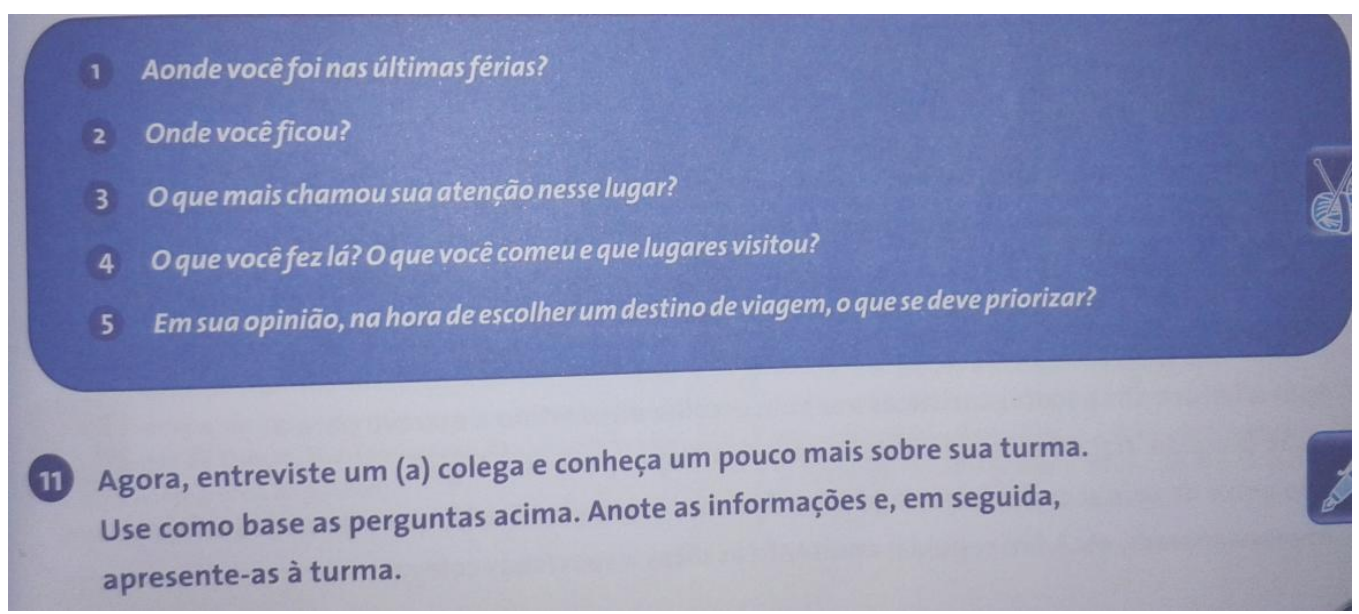

Fonte: Brasil Intercultural (p. 59)

Na página anterior à atividade 11, há um diálogo fictício entre duas colegas de trabalho que retornaram das suas férias e estão conversando sobre esse assunto. Trata-se da unidade 3, Descobrindo o mundo, que aborda entre outros o tradicional tema "o que você fez nas férias passadas" para introduzir o pretérito imperfeito do indicativo. De fato, nesta mesma unidade dedica-se a página 55 inteira à explicação do uso e conjugação desse tempo verbal, realçado em negrito nos textos das páginas 52 e 53.

Cabe destacar também que as atividades pré-comunicativas que fogem ao padrão tradicional "o professor pergunta e o aluno responde", representam apenas $25 \%$ (Troca de informação $4 \%$ + Desempenho de papéis $10 \%$ + Busca e reprodução de informação $11 \%$ ) do total das atividades pré-comunicativas de Brasil Intercultural. Por outro lado, ainda que respondam a outro tipo de padrão que não o tradicional, guardam traços formalistas já que, como foi reforçado na caracterização de cada tipo de atividade, o foco é promover o uso de certos conteúdos linguísticos preventivamente explicitados e planejados para cada unidade.

Quanto às Atividades Comunicativas, elas representam 9\% do total de atividades impulsionadas pelo material. Desses 9\%, (14 atividades), 8 correspondem a Produção de Gêneros textuais, 3 são tarefas e 2 são jogos (adivinhação e quiz). Nessas atividades o objetivo principal é produzir significados, envolver os alunos em 
comunicação real, como na resolução de um problema, um jogo, uma tarefa ou a criação e execução de um projeto (STERN, 1992).

\title{
Gráfico 4- Tipo de atividades comunicativas de "Brasil Intercultural"
}

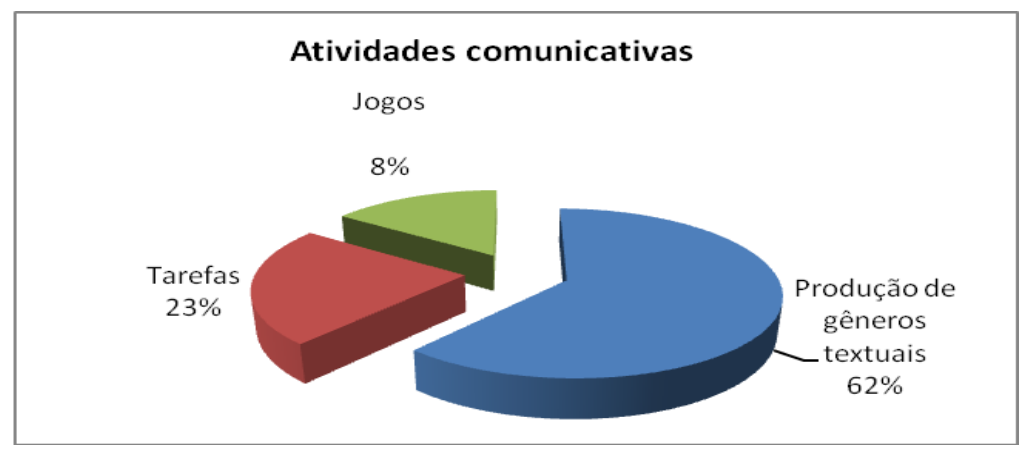

- Produção de Gênero Textual: trata-se de uma atividade que propõe a escrita de diversos textos: informativo, narrativo, de opinião, carta, lista, convite, e-mail. Geralmente essa atividade integra compreensão oral de áudio ou vídeo ou de texto escrito, com insumo autêntico, para posterior produção escrita de determinado gênero envolvendo uma situação/experiência de comunicação que pode ser encontrada na vida real.

Este tipo de atividade é usado no exame de proficiência CELPE-BRAS (BRASIL, 2013, grifo meu):

\begin{abstract}
As tarefas que compõem a Parte Escrita do Celpe-Bras propõem, assim, a realização de uma ação mediada pelo uso da linguagem por meio de textos organizados de forma socialmente construída. Isso significa que cada tarefa solicitará que o examinando se coloque em determinada posição social (enunciador) e, a partir dessa posição, compreenda o texto (oral, escrito ou multimodal) apresentado, selecione as informações adequadas e escreva a uma determinada pessoa ou grupo de pessoas (interlocutor) a fim de realizar uma determinada ação (propósito). São os elementos da tarefa que delimitam para o examinando as condições de produção de leitura e escrita, construindo um texto pertencente a determinado gênero do discurso, ao mesmo tempo em que fornecem os parâmetros para a avaliação.
\end{abstract}

Como vemos, o exame caracteriza essa atividade como "tarefa" e nesta dissertação a tarefa está enquadrada em outra categoria. Isso se deve ao fato de termos adotado o conceito de tarefa de Barbirato (1999, ver anexo 5) mais voltado à interação já que, conforma assevera Stern (1992), aprender a escrever, como na atividade de 
"Produção de gênero textual" nos força a focalizar em certo ponto no código, ainda que seja uma atividade que também fazemos na vida real, do meu ponto de vista.

\section{Figura 16 - Exemplo de Atividade Comunicativa "Produção de Gênero Textual"}

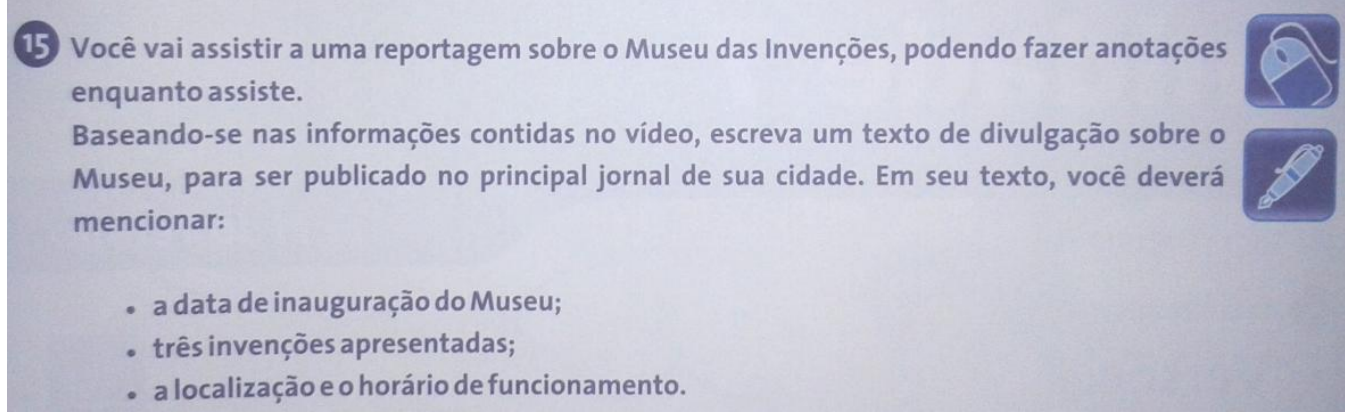

Fonte: Brasil Intercultural - Ciclo Básico (p. 113)

- Tarefa: segundo o Glossário de Linguística Aplicada (GLOSSA) é uma

"Atividade longa produzida geralmente aos pares ou em pequenos grupos que parte da colocação de uma situação problemática a ser "resolvida" através de intensa interação entre os participantes na própria língua-alvo”.

Prabhu (1987, p.24) define a tarefa como uma [...] atividade que requer do aprendiz chegar a um resultado de uma dada informação através de algum processo de pensamento, controlado e regulado pelos professores [...] como interpretar um horário, um mapa ou um conjunto de regras, dar um conjunto de direções, decidir qual declaração é a mais adequada e por quê. Para Nunan $(1989$, p.10) a tarefa comunicativa é

[...] uma parte do trabalho de sala de aula que envolve os alunos na compreensão, manipulação, produção ou interação na língua-alvo enquanto a atenção está principalmente focalizada no significado em vez da forma.

No anexo 5 (p. 155), encontra-se a tipologia expandida de tarefas de Barbirato (1999) tomada como base para classificação das tarefas identificadas nos materiais didáticos analisados neste trabalho de pesquisa.

Barbirato (1999, p. 63), com base em Nunan (1989), ilustra os componentes de uma tarefa da seguinte maneira: 
Figura 17 - Componentes de uma Tarefa

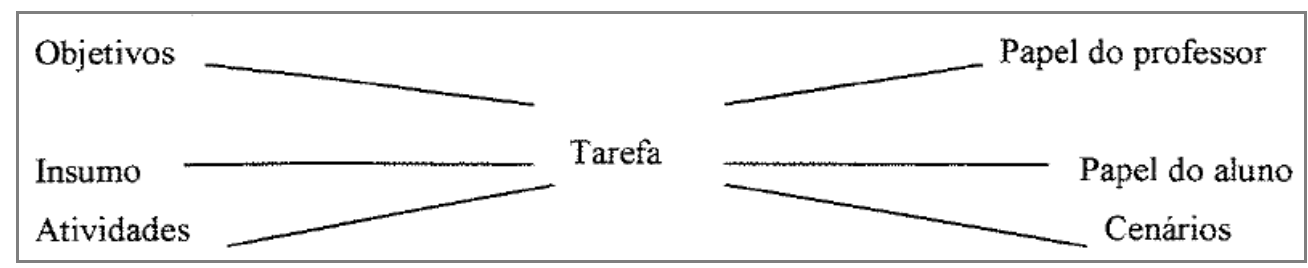

Fonte: Barbirato (1999, p.63)

a- Objetivos: equivalem às intenções subjacentes a qualquer tarefa de aprendizagem (NUNAN, 1989, p. 48)

b- Insumo: são os dados que formam o ponto de partida para a tarefa (NUNAN, 1989 , p. 53)

c- Atividades: especificam o que os alunos devem fazer com o insumo (NUNAN, 1989).

d- Cenário: refere-se à organização dos alunos em classe em pares, em grupos, entre todos ou individual (NUNAN, 1989 ).

e- Papéis: são pré-estabelecidos pela tarefa. Os alunos podem ser negociadores corresponsáveis do processo de aprendizado junto com os colegas e o professor (BREEN \& CANDLIN, 1980) entrevistadores, vendedores, críticos de cinema vendedores (NUNAN, 1989), colunistas de um jornal, cronistas, jornalistas, condutores de um programa de rádio ou $\mathrm{TV}$, atendentes, entre outros. $\mathrm{O}$ professor pode desempenhar o papel de facilitador, gerenciador, avaliador (NUNAN, 1989), negociador, co-comunicador, conselheiro (LARSENFREEMAN, 1986).

Segue um exemplo de atividade classificada como tarefa em Brasil Intercultural: 
Figura 18 - Exemplo de Atividade Comunicativa "Tarefa "(Interação social: desempenho de papéis controlados por meio da situação e de objetivos)

Entreviste seu/ sua colega sobre as pessoas que ele/ ela admira. A seguir, compartilhe
as respostas obtidas com o grupo e descubra com quem você tem mais afinidades.
\begin{tabular}{|l|l|l|}
\hline Campo & \multicolumn{1}{|c|}{ Personalidade } & Motivo da admiração \\
\hline Música & & \\
\hline Cinema & & \\
\hline TV & & \\
\hline Esporte & & \\
\hline Literatura & & \\
\hline Politica & & \\
\hline Religião & & \\
\hline Outros & & \\
\hline
\end{tabular}

Fonte: Brasil Intercultural - Ciclo Básico (p. 102)

Essa atividade da Unidade 6, "Personalidades", envolve os aprendentes na produção e negociação de significados ao assumir diferentes papéis (entrevistador e entrevistado). $\mathrm{O}$ entrevistado precisará fazer perguntas para obter as informações sobre os famosos que seu colega admira e deverá compartilhar as respostas com o grupo, assim como o entrevistado deverá descobrir, por meio das narrativas dos outros entrevistadores, quais são os colegas que tem mais características em comum.

- Jogos: armar um quebra-cabeça, adivinhar, resolver uma cruzadinha, interpretar uma cena teatral, jogar baralho, são atividades que precisam da interação exigida de maneira subjacente pela intenção de alcançar o desafio que o jogo em si proporciona. Segundo Aragão Mello (2013) o uso do lúdico propicia interação comunicativa entre os pares e tem um papel facilitador da aprendizagem significativa. No MD em questão, há apenas duas atividades desse tipo, um "quiz" e um jogo de adivinhação: 


\section{Figura 19 - Exemplo de Atividade Comunicativa "Jogos" (Adivinhação)}

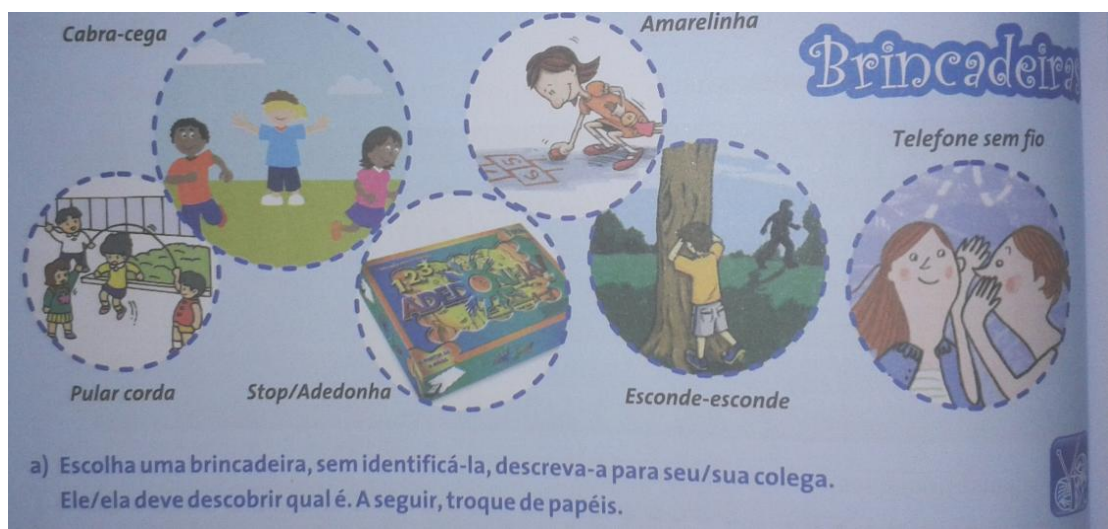

Fonte: Brasil Intercultural - Ciclo Básico (p. 76)

Como visto, as atividades comunicativas representam um número pouco significativo no total de atividades observadas nesse LD.

Quanto às Atividades de Prática do Código Linguístico identificadas, elas representam $41 \%$ do total das atividades oferecidas em BI ainda que o livro do aluno seja acompanhado de um volume de exercícios que proporciona em grande número, também, atividades focadas na prática da forma. No gráfico abaixo, pode-se observar a taxonomia criada para esta categoria:

\section{Gráfico 5- Atividades de Prática do Código Linguístico}

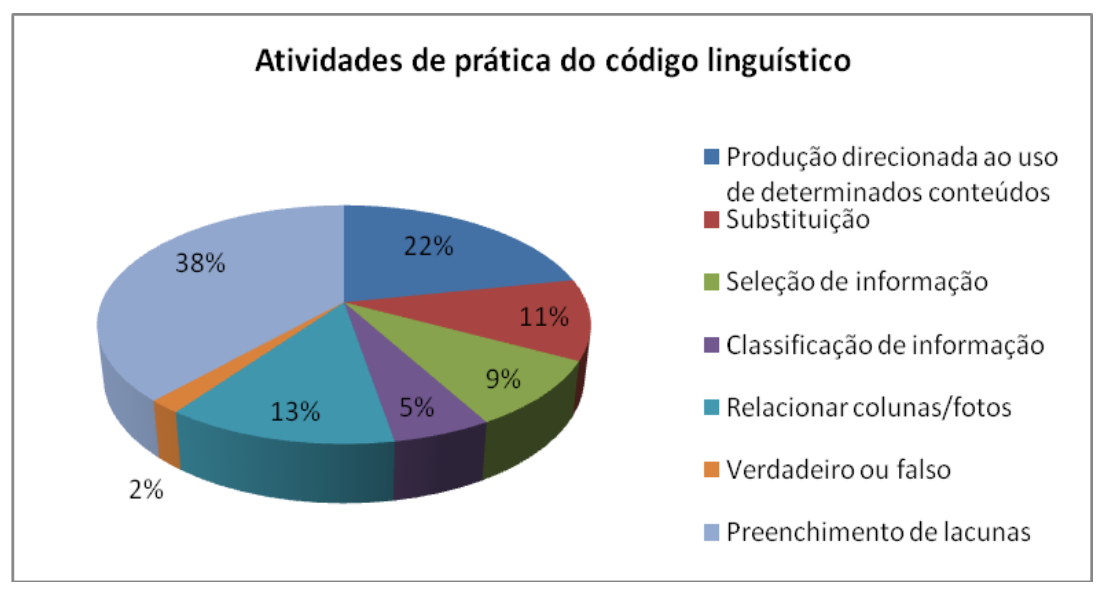

Aos fins práticos, como essa tipologia de atividades predomina nos materiais didáticos para o ensino de LE, os exemplos foram colocados no Anexo 6 ( $a, b$ e c). Isso não quer dizer que essas atividades não devem existir em um MD ou que não sejam 
relevantes para o ensino de uma nova língua. $\mathrm{Na}$ verdade, são atividades que quando predominam em um MD ou na aula circunscrevem o ensino à sistematização e à aprendizagem da língua enquanto código sem muita atenção (ou sem atenção nenhuma) à produção de significado e ao uso significativo da língua enquanto instância de comunicação, ação e interação.

Em BI, 38\% das atividades de prática do código são dedicadas ao Preenchimento de lacunas com verbos, pronomes e preposições. Em segundo lugar, $22 \%$ foram classificadas como "Produção direcionada ao uso de determinados conteúdos" e em terceiro lugar, com 13\%, as atividades "Relacionar colunas/fotos", clássicos exercícios de vocabulário. Segue a definição descritiva de cada uma dessas categorias identificadas no material didático:

- Preenchimento de lacunas: compõe-se de um texto com lacunas para serem preenchidas com verbos conjugados (dados entre parênteses no infinitivo), preposições, pronomes, estruturas comparativas, vocabulário, entre outros tópicos do sistema linguístico (Ver Anexo 6, p. 157).

- Produção direcionada ao uso de determinados conteúdos: trata-se de uma atividade que prioriza a prática escrita ou oral (ou primeiro escrita e depois oral, ou as duas ao mesmo tempo) de conteúdos linguísticos (vocabulário ou gramática, uso de preposições, por exemplo) explicitados anteriormente na teoria do livro, sob o formato tradicional de pergunta resposta, cópia de informações, rotinizações (Ver Anexo 6, p.157).

- Relacionar Colunas/fotos: nessa atividade, logo após insumo em texto ou imagens, propõe-se relacionar palavras do insumo em uma coluna a outras em outra coluna com significado equivalente. No caso das fotografias, geralmente pede-se que se associem a textos explicativos ou listas de vocabulário (Ver Anexo 6a, p.158).

- Substituição: com foco no vocabulário também, expressões ou palavras são isoladas do insumo previamente dado para serem substituídas por outras de significado equivalente (Ver Anexo 6b, p. 159).

- Seleção de informação: trata-se de um exercício de seleção de sons a serem listados por categorias segundo as regras fonéticas após ouvir um áudio ou ler um texto (Ver Anexo 6b, p. 159). 
- Classificação de informação: este exercício também prioriza a classificação de palavras extraídas de um insumo previamente apresentado em categorias representativas das variedades de sons da fonética da língua-alvo (Ver Anexo 6b, p.159).

- Verdadeiro ou Falso: após um texto, vídeo ou áudio é apresentado um exercício com informações verdadeiras ou falsas sobre o mesmo para o aluno julgar de acordo com o que interpretou (Ver Anexo 6c, p. 160). As informações falsas devem ser corrigidas.

Conforme verificado na definição de todos os tipos de exercícios da categoria “Atividades de prática do código linguístico", em todos os casos o ponto de partida prioriza o treino de um aspecto do sistema linguístico, seja por meio da escrita, da fala, audição, repetição, associação, seleção ou classificação, sempre há uma rotinização relacionada à prática de um tópico de gramática, vocabulário ou fonética. De maneira alguma, não quero dizer que essas atividades não sejam válidas para o ensino de LE, mas que a configuração preventiva das mesmas em um MD é o reflexo de uma concepção de ensinar línguas menos voltada para a atenção às necessidades dos alunos. Em uma visão mais renovada, esses mesmos exercícios podem ser apresentados para os alunos em função das necessidades observadas pelo professor e manifestadas pelos alunos durante as aulas. Dessa maneira, a configuração das experiências na sala de aula muda por inteiro.

\section{Insumo}

O Glossário de Linguística Aplicada (GLOSSA) define insumo como "Toda manifestação de linguagem na língua-alvo que pode, eventualmente, se tornar competência comunicativa na interlíngua. $\mathrm{O}$ insumo tem de ser recebido por um filtro afetivo favorável para que tenha chance de se converter em competência adquirida. Não deve ser gramaticalmente sequenciado e precisa ser de interesse ou relevante ao aprendente. $\mathrm{O}$ insumo pode ser produzido entre os participantes ou trazido pronto para a sala de aula".

Seguindo as hipóteses de Krashen (1982), apenas adquirimos quando o insumo é "compreensível e um pouco acima do nosso nível de entendimento", o que ele chama de 
“input +1 ". Além disso, a fala do professor na sala de aula deve ter certas modificações e adequações ao nível de compreensão dos alunos com o objetivo de auxiliá-los no entendimento do que se diz e levá-los adiante na compreensão cada vez mais sofisticada da língua-alvo. O professor pode alterar o ritmo da fala na LE, modular mais, repetir, dizer de variadas maneiras os sentidos, incluindo gestos, por exemplo. Por outro lado, segundo o mesmo autor (op. cit.), quando o insumo tem valor de verdade, baseado em situações reais (verossímeis), o aluno terá a oportunidade de retomar essas situações, verificar o insumo (GONZÁLEZ e SALES HAYASHI, 2013, p.7).

Em Brasil Intercultural, há insumo em boa quantidade e qualidade em diversos gêneros textuais (orais, escritos e multimodais) com cortes e adaptações, de fontes autênticas (reais) como internet, jornais, revistas, CDs, entre outros. Entre esses textos encontram-se: artigos, fotografias, desenhos, músicas, frases célebres, poemas, vídeos, mapas. Todo o insumo é de fontes autênticas, os vídeos são de reportagens de Jornais da TV brasileira, de artistas brasileiros, entre outros.

Nesses materiais são abordados aspectos que revelam elementos culturais, sociais, históricos e políticos que caracterizam, em amostras, a diversidade cultural brasileira. Cabe destacar que um dos princípios da abordagem comunicativa é o uso desse tipo de insumo. No entanto, ele é mais bem aproveitado quando usado em atividades comunicativas já que pode ser retrabalhado e recuperado no decorrer da/s unidade/s e em situações da vida real.

Long $(1983,1985)$ foi o primeiro a defender que os aprendentes de L2 precisam participar ativamente quando recebem insumo, pois apenas ouvir não é suficiente para a aquisição de uma língua. Para esse autor (op. cit.), durante a interação, os aprendentes fazem esforços comunicativos, essenciais para a aquisição de língua, usam estratégias tais como, repetições, pedido de confirmações, verificações de compreensão ou pedidos de esclarecimento. No Anexo 7, foram exemplificados alguns recortes do insumo oferecido pelo livro.

\subsubsection{Análise de Horizontes: Rumo à Proficiência em língua Portuguesa}

Em 2013, esse MD já teve uma unidade analisada (vide Gottheim e Pereira, 2013), Unidade 1 "Solidariedade", "abrangendo nos textos e nas tarefas o insumo potencial para a comunicação (sobre o que falar) e/ou fixação gramatical que a unidade 
apresenta" (GOTTHEIM e LOPES, 2013, p. 220). Os autores da análise julgaram essa unidade como rica em insumo e proposição de tarefas significativas, tanto orais quanto escritas, [...] para aplicação em contextos variados de agrupamento social na sala de aula [...] (GOTTHEIM e LOPES, 2013, p. 226) que permitiu verificar o alcance dos objetivos inerentes a uma experiência intercultural ${ }^{7}$, pois o livro e a unidade em análise foram construídos com base em princípios da "Abordagem Comunicativa Intercultural" segundo as autoras.

\section{Unidades}

Nesse MD o princípio organizador das experiências propostas nas unidades são tópicos do mundo contemporâneo com seus respectivos temas:

- Unidade 1- Solidariedade: ONGs, causas sociais, gentileza.

- Unidade 2 - Saúde e Bem-Estar: o tempo, fast-food, junk food, pratos típicos brasileiros, alimentos e stresse.

- Unidade 3 - Tempos Modernos: idade na amizade e namoros, estilo de vida do jovem burguês, tribos, piercing e tatuagem, moda.

- Unidade 4 - Ecologia: hábitos de consumo, lixo, sustentabilidade, Índios e Amazônia.

- Unidade 5 - Relacionamentos: paquera, poliamor, a mulher solteira, relacionamentos no trabalho, o homem cordial.

- Unidade 6 - Educação: diploma e mercado de trabalho, estudantes, sistema educativo brasileiro, cotas, preconceito.

- Unidade 7 - Trabalho: subvalorização profissional (profissões invisíveis à sociedade), atitudes masculinas e femininas no trabalho, mudanças de profissão,

- Unidade 8 - Turismo: a viagem como terapia, viajar só, gafes culturais, roteiro de festas populares, roteiro de cidades históricas.

- Unidade 9 - Tecnologia: internet, terceira idade, internetês, namoro virtual, a aviação.

\footnotetext{
${ }^{7}$ Segundo Moran (2001), são quatro os principais quesitos que podem ser trabalhados com os alunos para ter uma experiência intercultural de ensino e aprendizagem de línguas: a) adquirir informação cultural, b) desenvolver comportamentos culturais c) descobrir explicações culturais, d) articular respostas pessoais para o que estão aprendendo e d) e a capacidade de estabelecer e manter relação com pessoas de outras culturas.
} 
- Unidade 10 - Cidades: megacidades e poluição, pedágios, trânsito, Rio e São Paulo, capitais brasileiras, periferia.

Cada um dos tópicos e temas é apresentado por meio de diversos gêneros textuais escritos e orais que fornecem o insumo para as atividades propostas. Cada um desses tópicos proporciona por meio da leitura e realização das atividades, o aprendizado dos temas. No entanto, ainda que esse seja o eixo organizador central das unidades também há espaço para sistematizações de tópicos linguísticos em torno do insumo. Por outro lado, a identificação desse princípio organizador permite inferir que o planejamento implícito no MD seja comunicativo.

Assim, é possível afirmar que a natureza dos conteúdos das unidades é comunicativa, não só por promover a aprendizagem da língua por meio de tópicos do mundo moderno, pois os tópicos não são trazidos propositalmente porque priorizam o uso de certas estruturas e vocabulário, mas porque, por meio do aprendizado deles, se produz um esforço significativo de adquirir um novo conhecimento usando uma nova língua que também é alvo de aprendizagem. Esse tipo de esforço, chamado por Prabhu (1996) como "desdobramento", envolve um processo subconsciente do desenvolvimento do sistema da língua, provocado e promovido quando a linguagem é empregada como um recurso que produz um esforço para entender o mundo, o modo como o aprendiz lida com a informação nova adquirida na língua alvo.

\section{Atividades}

A natureza das atividades oferecidas por Horizontes é uma consequência do princípio organizador dos conteúdos das unidades. Apenas $36 \%$ das atividades são orientadas pela prática do código linguístico e o restante $64 \%$ se divide entre atividades de índole comunicativa e pré-comunicativa. Segue o detalhe dessa porcentagem em formato de gráfico: 
Gráfico 6- Tipo de atividades do LD "Horizontes"

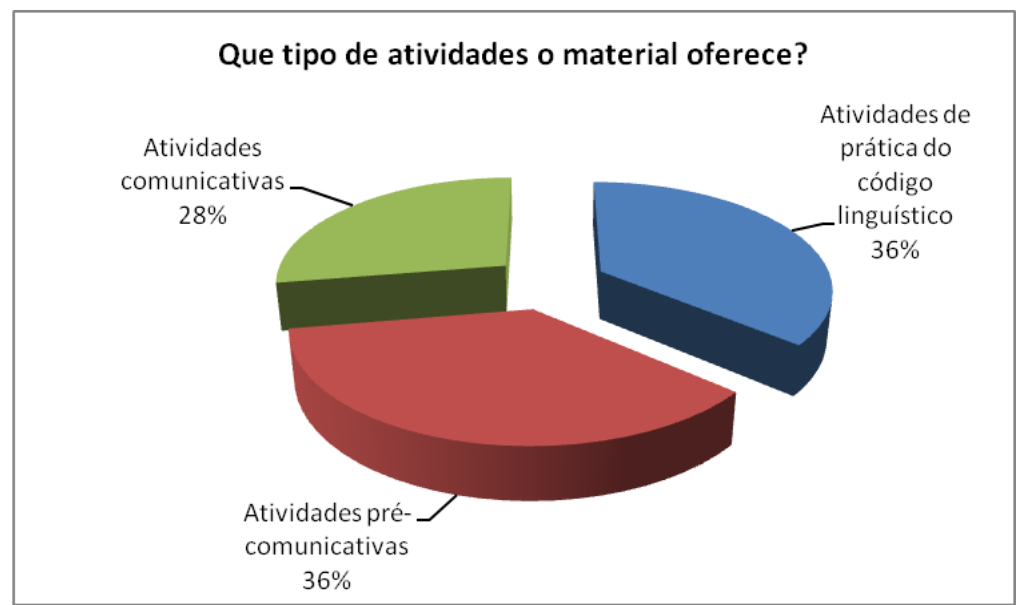

Em Horizontes, foram identificadas como Atividades Pré-comunicativas aquelas que seguem o formato tradicional de pergunta e resposta (BARBIRATO, 1999), sem necessariamente em todos os casos estarem direcionadas ao uso/prática de determinados conteúdos, e aquelas que dão trilhos para os alunos solucionarem a atividade que de alguma maneira tiram o foco da construção de sentido. O gráfico e a figura a seguir ilustram essa afirmação:

\section{Gráfico 7- Tipo de Atividades Pré-comunicativas de "Horizontes"}

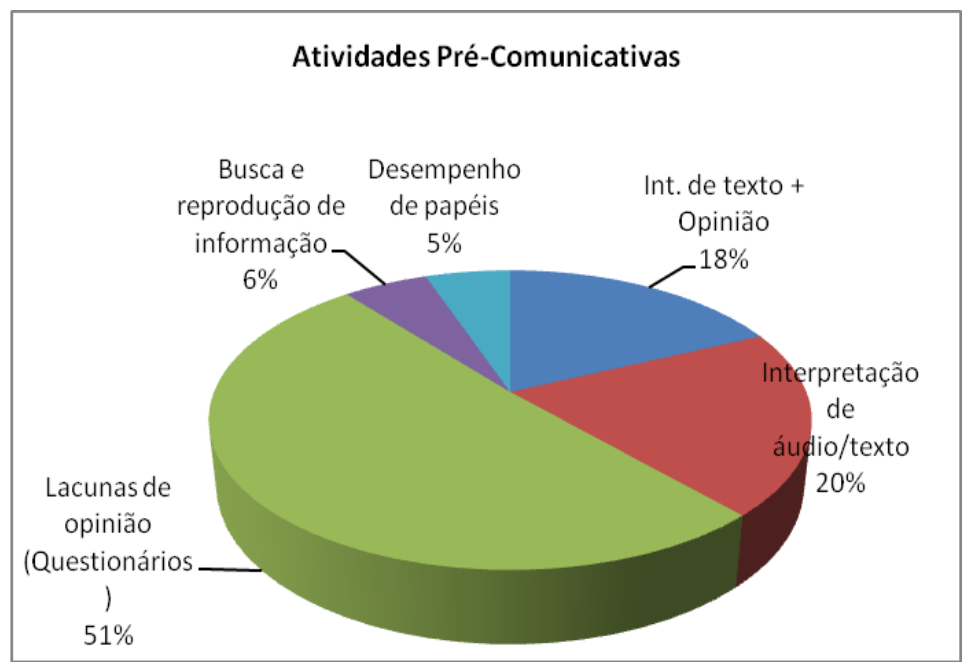




\section{Figura 20 - Exemplo de Atividade Pré-Comunicativa "Desempenho de papéis"}

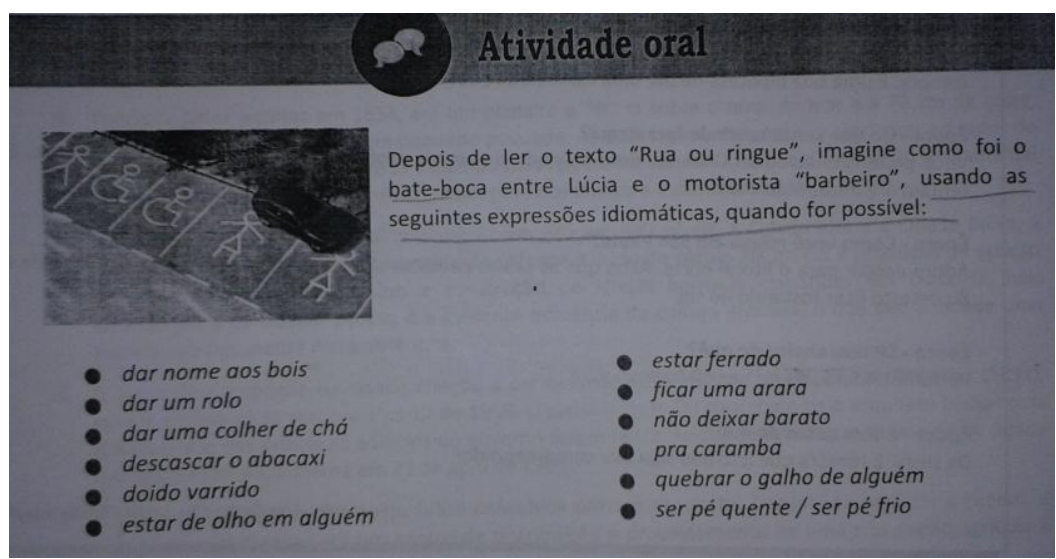

Fonte: Horizontes: Rumo à Proficiência em Língua Portuguesa (p. 119)

$\mathrm{Na}$ atividade exemplificada, ainda que o uso das expressões possa acontecer apenas quando for possível, isso é um condicionante da atenção do aluno, pois altera o foco, do papel que o aprendente vai representar, para a tentativa de uso das expressões dadas. Quero dizer que a sugestão de emprego dessas gírias durante o desempenho de papéis desvia a atenção da construção do significado. Nessa análise, é possível verificar, como afirmado nas asserções (p.) sobre o LD Brasil Intercultural, que uma categoria de atividade pode existir tanto na tipologia pré-comunicativa quanto na comunicativa, pois o que muda é o ponto de partida para a configuração e resolução da mesma.

Quanto às atividades de "Lacunas e Questionários de Opinião, de Interpretação de Texto/Áudio e Busca e Reprodução de informação", todas mantêm as mesmas características de $\mathrm{BI}$ : formato tradicional pergunta-resposta, papel do aluno limitado a respondedor de perguntas e do professor como questionador, banalização do termo "pesquisa" nas atividades de "Busca e Reprodução de informação", nas quais, assim como em BI, os temas para busca são pré-selecionados pelos autores do MD.

As "Atividades Comunicativas" representam o $28 \%$ do total de atividades oferecidas pelo LD, nas quais a "Produção escrita de diversos gêneros textuais" é a categoria predominante. 


\section{Gráfico 8 - Tipologia de Atividades Comunicativas}

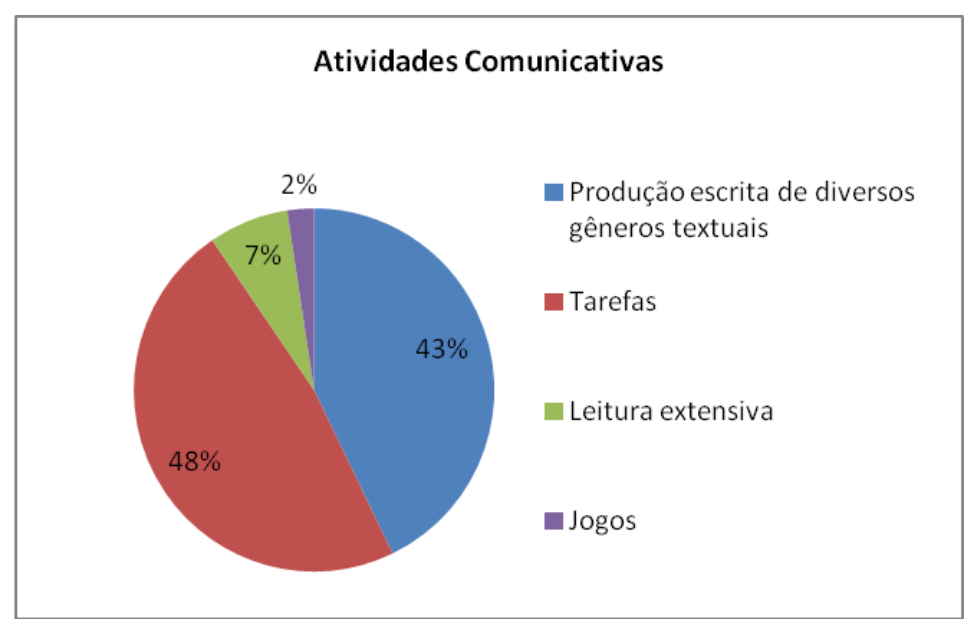

Assim como em BI, a "Produção escrita de gêneros textuais" foi categorizada como comunicativa, por tratar-se de uma atividade exigida pelo exame de proficiência CELPE-BRAS e assim definida pela Comissão Técnico-Científica desse exame. Tratase de um tipo de atividade com alto grau de verossimilhança ainda que com certo foco no código e carente de interação, por esses dois motivos, assim como em BI, essa categoria também não foi enquadrada na categoria "tarefa".

\section{Figura 21 - Exemplo de Atividade Comunicativa "Produção escrita de diversos gêneros textuais"}

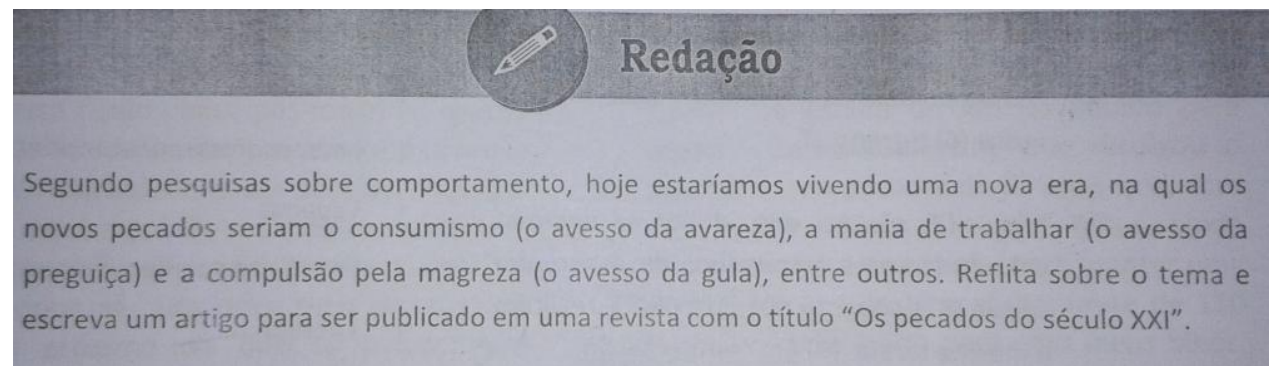

Fonte: Horizontes: Rumo à Proficiência em Língua Portuguesa (p. 10)

Quanto às "Tarefas", foram identificadas duas tipologias definidas por Barbirato (1999, ver Anexo 5, p. 155) como 1- Interação Social: a- lacuna de opinião, bdesempenho de papéis (controlado por meio da situação e dos objetivos), ccompartilhar e contar, 2- Cognitivas: resolução de problemas. Seguem alguns exemplos: 


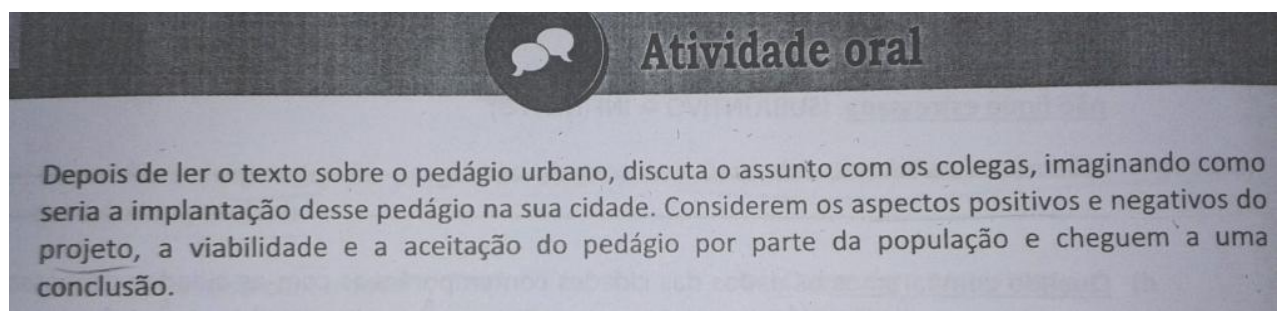

Fonte: Horizontes: Rumo à Proficiência em Língua Portuguesa (p. 116)

Essa atividade propõe a leitura do texto "O que é um pedágio urbano" para posteriormente o aluno discutir com os colegas a implantação do mesmo na cidade onde moram. Esse tipo de interação se dá frequentemente na realidade, em reuniões com amigos, familiares ou no trabalho, situações nas quais tomamos parte numa discussão sobre uma questão social (PRABHU, 1987) ou sobre temas atuais e polêmicos. É uma atividade que permite a administração de turnos pelos alunos para, durante a interação, chegar ao resultado solicitado pela atividade: uma conclusão sobre o tema discutido. Os aprendentes têm liberdade absoluta para resolver essa atividade, listando os aspectos positivos e negativos, definindo papéis para cada um dos colegas, ou seja, não há nenhum procedimento objetivo para demonstrar resultados como certos ou errados (PRABHU 1987). Atividades como essas permitem que o aluno assuma diversos papéis: negociadores, moderadores, críticos (NUNAN, 1989).

Figura 23- Exemplo de Atividade Comunicativa "Tarefa de Interação social: desempenho de papéis (debate) controlado por meio da situação e dos objetivos"

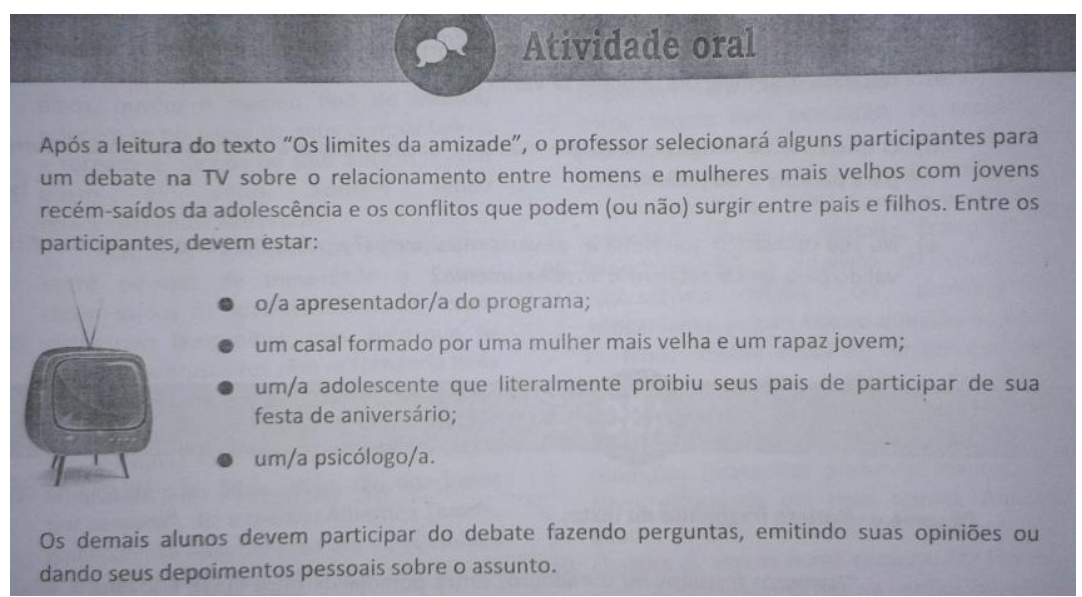

Fonte: Horizontes: Rumo à Proficiência em Língua Portuguesa (p. 30) 
$\mathrm{Na}$ atividade da Figura 23, é proposta a simulação de um debate na televisão para o qual o professor designará papéis específicos a cada aluno. Há uma clara situação de comunicação do mundo real na qual os alunos deverão interpretar os papéis designados (uma identidade simulada nesse caso) usando linguagem adequada ao meio de comunicação massivo. Segundo as características do cenário descrito para ser simulado na atividade, há uma situação dramática que permite incluir tom emocional, postura, gesto e ações apropriadas (STERN, 1992), ou seja, uso linguístico completo e complexo.

\section{Figura 24 - Exemplo de Atividade Comunicativa "Tarefa cognitiva: resolução de problemas"}

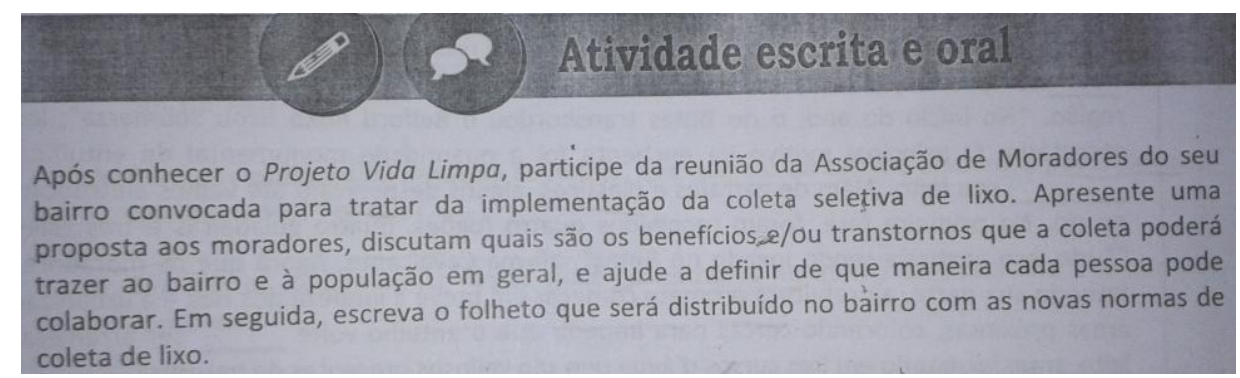

Fonte: Horizontes: Rumo à Proficiência em Língua Portuguesa (p. 42)

No exemplo dessa Tarefa cognitiva, promove-se uma discussão para resolver o problema da coleta seletiva de lixo do bairro onde moram os participantes. Os alunos deverão apresentar uma proposta aos moradores para mostrar benefícios e transtornos dessa coleta e também deverão elaborar um folheto com as novas normas da coleta de lixo. Portanto, nessa atividade há um problema a ser resolvido (STERN, 1992), implantar a nova maneira de se coletar o lixo. Segundo Barbirato (1999, p.75), esse tipo de tarefa envolve mais os aprendentes no uso da língua-alvo em pequenos pares ou em grupos, com foco no problema, na tomada de decisões, ou seja, nas características da atividade, do que em aspectos formais da língua.

Quanto à "Leitura Extensiva" (Atividade Comunicativa), segundo Day \& Bamford (1997), trata-se da atividade de ler em quantidade com o objetivo de compreender o texto como um todo, no seu sentido global, o que normalmente não acontece nas aulas de línguas e suas extensões em que "tradicionalmente o texto tem de ser seguido por várias perguntas de compreensão que levam a que o aluno recorra ao 
scanning para rapidamente encontrar a informação específica de que necessita" (HARMER, 2001, apud MENDONÇA 2007, p. 60)

Pesquisas recentes (Mendonça 2012, Grundy 2004) mostram que a leitura extensiva é um elemento motivador e promotor de chances de aquisição da LE alvo. Nunan (1991, p. 81) reconhece dois pontos de vista sobre a leitura. Por um lado o behaviorista-skinneriano e por outro o cognitivo-sociológico. Na primeira perspectiva, pouco adequada para o autor (op. cit.), foca-se principalmente a decodificação de palavras e estruturas. A segunda, uma perspectiva top down, considera que a leitura é um processo abrangente de compreensão que envolve sensações, emoções, aspectos intelectuais, fisiológicos, neurológicos, culturais, econômicos e políticos. Trata-se de um enfoque no qual o leitor está no centro do processo, ele lê o texto, explora seu conhecimento de mundo, formula hipóteses que são ou não confirmadas, formula novas hipóteses e assim sucessivamente. Por conseguinte, valoriza-se a interação durante a leitura.

Para Mendonça (2012, p. 57), a leitura que normalmente se faz na sala de aula de LE não é agradável para os alunos, nem autêntica. Os professores deixam os estudantes incomodados com as correções constantes. A autora (op. cit.) afirma que a leitura é feita na sala de aula de uma maneira muito diferente da vida real. No dia a dia, raramente, devemos ler em voz alta. Por isso, quando é solicitado esse tipo de leitura durante as aulas, os alunos não se reconhecem como leitores. Por outro lado, eles enxergam a leitura como treino de pronúncia ou como exercício de interpretação de texto porque essas são as atividades propostas predominantemente nos livros didáticos.

A leitura extensiva pode ser oferecida como parte do programa de um curso de línguas (BELL, 1998). Nesse caso o professor pode planejar preventivamente as leituras em função dos interesses dos alunos, as leituras podem estar já incorporadas nas unidades do material didático adotado em função do tema de cada unidade, ou o aluno pode ter acesso a uma biblioteca, por exemplo, para selecionar os textos que vai ler. No primeiro caso, o professor deve sondar os interesses dos alunos para selecionar as leituras, e decidir se dará tempo para ler durante as aulas (leitura silenciosa) ou se será uma atividade extraclasse. Por outro lado, segundo Bell (op. cit.) o professor deve monitorar o andamento das leituras para motivar os alunos nessa atividade e guiar a seleção de textos, no caso de um programa em que os alunos escolhem suas próprias leituras. 
No livro Horizontes, identifiquei leituras complementares no final das unidades 4, 5 e 9. Essas versavam sobre temas ligados ao tópico central da unidade, como por exemplo, na U4-Ecologia, na página 48 (Ver anexo 9, p. 164 ), propõe-se a leitura complementar (esse é o nome dado pelos autores à leitura extensiva) "Chico Mendes". Não há nenhum tipo de comando acompanhando a proposta eportanto ela pode ser interpretada como atividade extensiva (Abordagem Comunicativa) ou como atividade de leitura silenciosa em sala (Abordagem Comunicativa), ou ainda pode ser feita em grupo e em voz alta com o professor formulando perguntas para testar a interpretação dos estudantes (Abordagem Gramatical).

Conforme citado anteriormente, com base em Nunan (1991), Mendonça (2012), Bell (1998) e Grundy (2004), essa última postura não é a ideal para o uso da leitura extensiva num curso de LE uma vez que enquadra a atividade nos padrões tradicionais de pergunta resposta e tira a autenticidade e o prazer que a leitura proporciona na vida real. Por outro lado, ao meu ver, ainda que a porcentagem dessas leituras seja mínima (7\%) do total de atividades comunicativas do livro, cabe destacar que nos MDs de PLE não se encontram frequentemente esse tipo de atividade. De fato, em BI, essa categoria não foi identificada. Todas as leituras estão acompanhadas por um questionário de interpretação e/ou de opinião.

Além disso, em Horizontes, nas páginas 132 e 133 há uma lista de sugestões para cada unidade com leitura extensiva, filmes, documentários e sites para visitar sobre os tópicos da cada unidade: solidariedade, saúde, tempos modernos, ecologia, relacionamentos, educação, trabalho, turismo, tecnologia, cidade, história, arte literatura, música (Ver anexo 8, p. 162). Outro aspecto para destacar nesse material didático são as informações sobre o exame de proficiência CELPE-BRAS que o livro proporciona na página 133 (Ver anexo 10, p. 165).

Para finalizar a análise desta categoria, apenas um jogo faz parte do acervo de atividades lúdicas comunicativas de Horizontes. Trata-se de uma cruzadinha na página 110.

Quanto às Atividades de Prática do Código Linguístico, elas constituem 36\% do total de atividades do livro. Exercícios de substituição, seleção e classificação de informação, relacionar colunas/fotos, exercícios de transformação e preenchimento de lacunas fazem parte do acervo das atividades que têm como ponto de partida um 
conteúdo de gramática, fonética, vocabulário, ou seja, em que a língua enquanto sistema é o conceito que define a natureza das experiências promovidas nas atividades.

\section{Gráfico 9- Atividades de prática do código linguístico}

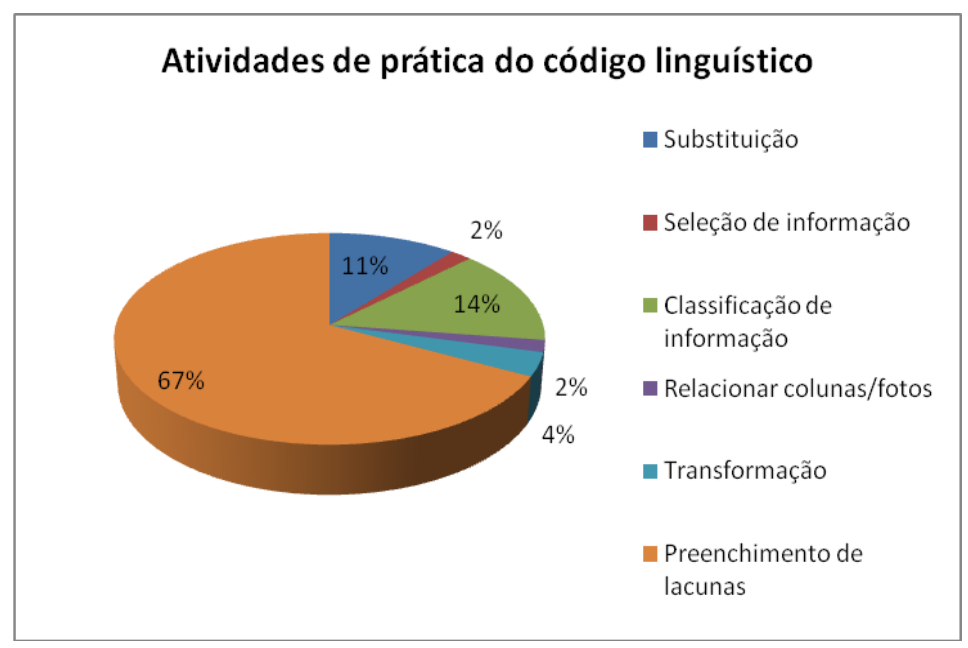

\section{Insumo}

Como em BI, este MD oferece insumo em boa quantidade e qualidade em diversos gêneros textuais (orais, escritos e multimodais) com cortes e adaptações, de fontes autênticas (reais) como internet, jornais, revistas e CDs. Entre esses textos encontram-se: artigos, fotografias, desenhos, músicas, frases célebres e poemas. Nesse insumo são abordados temas do tópico central de cada unidade. Cabe destacar, como explicado anteriormente, que no final do livro há uma lista de sugestões dos mais variados insumos sob o formato de livros, vídeos, filmes, entre outros, para serem explorados pelos usuários do material.

Cabe salientar que o insumo de Horizontes é majoritariamente composto por textos escritos de diversas fontes autênticas e os áudios se limitam a canções de artistas brasileiros. Ao estabelecer uma comparação entre o insumo de um material e outro, Brasil Intercultural tem textos de diversas fontes e modalidades (escritos, orais e multimodais). Não obstante, não é tão aproveitado (retrabalhado nas atividades) quanto em Horizontes pela divergência na tipologia de atividades que aborda o mesmo. Nesse ponto, infiro que é necessário cruzar a informação obtida do insumo com as atividades para avaliar, no momento da seleção do material prévia ao uso, em qual dos didáticos 
analisados o insumo é mais bem aproveitado nas atividades para dar aos alunos oportunidades de uso e de experienciar a nova língua.

\subsubsection{Conclusões sobre a Abordagem predominante dos MDs}

Durante todo este capítulo, por meio de questões e categorias (unidades, atividades, insumo), descrevi analiticamente as características de abordagem dos MDs Brasil Intercultural e Horizontes. Essa descrição levou-me a interpretar e determinar por meio do cruzamento dos dados com a teoria resenhada no Capítulo 1 que nesses LDs predomina uma abordagem, ou seja, há contidos neles conceitos de língua, linguagem, de aprender e de ensinar língua estrangeira e papéis e atitudes de aprendizes e professores que advêm de determinadas linhas teóricas.

A descrição das duas obras, nas seções anteriores, foi talvez mais analíticodescritiva devido a que, como professora de línguas, seleciono meus materiais didáticos em função de princípios que constituem minha abordagem de ensinar e aprender, minha filosofia de trabalho, minhas concepções sobre língua, linguagem, língua estrangeira, aprender e ensinar. Por outro lado, esse olhar analítico-descritivo também quer dizer que não podemos apenas nos guiar pela descrição/declaração do livro feita pelos autores na apresentação, pois, às vezes, o que eles declaram não coincide com o que está codificado na obra (vide Fontão, 1991).

Cabe destacar e lembrar-se da pergunta guia, respondida a seguir, que orientou toda a análise do Capítulo 4:

\section{1- Qual é a abordagem predominante nos MDs de PLE produzidos na Argentina?} a- Quais traços da abordagem comunicativa e quais da abordagem gramatical esses materiais guardam?

Antes de focalizar a resposta, considero relevante, citar novamente o conceito de abordagem de Almeida Filho (1997, p 17-25, grifo meu) que norteou este trabalho

\footnotetext{
Abordagem: Força que orienta, e portanto, caracteriza em essência, todo um processo específico de ensino de línguas. Essa força advém das competências implícita (básica), teórica, aplicada e (meta) profissional do professor ou de quaisquer outros agentes ativos de ensino tais como autores de LD, planejadores de cursos, produtores de instrumentos de avaliação, pais, tutores, etc. Essas competências trabalham com
} 
posicionamentos explícitos no caso das competências aplicada, englobando a subcompetência teórica, e profissional, e com posicionamentos implícitos com intuições, disposições a partir de experiências prévias, cultura compartilhada de ensinar da região/escola, etc., no caso da competência implícita. A força da abordagem provém da energia da motivação para ensinar, opera com "matéria prima" de conhecimentos explícitos e implícitos e se desempenha no ensinar em níveis distintos de competências. Os implícitos são teoria formal subjetiva, intuitiva, muitas vezes na forma de crenças culturalmente marcadas pelo inconsciente coletivo. Os explícitos são teoria formalizada, aprendida, (re)construída e citável na forma de pressupostos e princípios estabilizados. Pode resultar contraditória a força da abordagem como resultado de posições teóricas conflitivas das três vertentes de que decorre a teoria: a concepção de linguagem (de língua, linguagem humana, língua estrangeira) a concepção de ensinar línguas, $e$ a concepção de aprender/adquirir língua, os papéis e atitudes de professor e aluno/aprendiz, e a concepção de sala de aula de que se parte para produzir o ensino. A abordagem orienta o processo ou operação global de ensino que se compõe ordenadamente no seu todo das fases do planejamento de cursos, de produção ou adoção via análise dos materiais das experiências realizadas para aprender, e das avaliações de rendimento efetuadas.

Toda a força (abordagem) analisada nos MDs "BI e Horizontes" emana das competências supracitadas dos autores. No entanto, não são eles o alvo de estudo mas as posições teóricas sobre aprender e ensinar uma língua estrangeira, língua, linguagem e língua estrangeira e os papéis e atitudes de professores e aprendizes que esses autores configuraram no conjunto da obra, no material didático em si (ALMEIDA FILHO, 1997).

\section{LD Brasil Intercultural}

Assim, após uma análise descritiva das características da abordagem do livro do aluno do Ciclo Básico, Brasil Intercultural, posso dizer que ele é um livro didático predominantemente pré-comunicativo e de prática do código linguístico, com algumas características da abordagem comunicativa. BI é um material que promove o preparo do aprendiz para futuras atividades de comunicação, ainda com traços característicos da abordagem gramatical e insumo em boa quantidade e qualidade, autêntico, como sugerido pelos princípios da abordagem comunicativa. Logo, trata-se de um livro didático em transição entre a abordagem gramatical e a abordagem comunicativa, caracterizado na análise desta pesquisa como livro "pré-comunicativo". Acredito que esse LD constitui uma produção muito valiosa que marca um precedente 
na história do mercado de elaboração de materiais didáticos para o ensino de PLE assim como na história da filosofia de trabalho da instituição que o criou.

No quadro a seguir detalho os traços de cada uma das duas macroabordagens, gramatical e comunicativa, que esse material guarda e a abordagem declarada pelos autores:

\section{Quadro 5 - Traços característicos de abordagem do LD Brasil Intercultural}

\begin{tabular}{|c|c|c|}
\hline & \multicolumn{2}{|c|}{ Traços característicos de Abordagem } \\
\hline $\begin{array}{l}\text { Indicadores } \\
\text { constitutivos }\end{array}$ & Abordagem comunicativa & Abordagem gramatical \\
\hline Unidades & & $\begin{array}{l}\text { - Organizadas em torno de tópicos } \\
\text { gramaticais, de vocabulário, fonética e } \\
\text { funções comunicativas. } \\
\text { - Conteúdos de gramática, vocabulário e } \\
\text { fonética selecionados preventivamente. } \\
\text { - Planejamento implícito: linear } \\
\text {-Tópicos que prioritariamente promovem o } \\
\text { ensino preventivo de determinadas estruturas } \\
\text { e não do tópico em si como uma experiência } \\
\text { cognitiva maior. }\end{array}$ \\
\hline Atividades & $\begin{array}{l}\text { - } 14(9 \%) \text { atividades voltadas à } \\
\text { produção de significados: jogos, } \\
\text { tarefas, produção de gêneros textuais. }\end{array}$ & $\begin{array}{l}\text { - } 40 \% \text { de atividades voltadas para praticar de } \\
\text { diversas maneiras (repetição, substituição, } \\
\text { seleção, classificação, preenchimento de } \\
\text { lacunas, relação de colunas/fotos, produção } \\
\text { proposital) conteúdos de gramática, } \\
\text { vocabulário e fonética. } \\
\text {-Pré-comunicativas: não são mecânicas mas } \\
\text { ainda estão vinculadas à prática da forma do } \\
\text { que à produção do significado. } \\
-7 \text { tipos de atividades pré-comunicativas } \\
(51 \%)\end{array}$ \\
\hline Insumo & $\begin{array}{l}\text { - boa quantidade e qualidade em } \\
\text { diversos gêneros textuais (orais, } \\
\text { escritos e multimodais) com cortes e } \\
\text { adaptações, de fontes autênticas } \\
\text { (reais) como internet, jornais, revistas, } \\
\text { CDs, entre outros. }\end{array}$ & \\
\hline & Abordagem declarada pelos a & es: "aborda \\
\hline
\end{tabular}

Em BI os conceitos contidos (implícitos) sobre aprender, ensinar uma LE, língua. Língua estrangeira e linguagem, em contraste com esses mesmos conceitos declarados pelos autores do LD na apresentação, foram explicitados no quadro a seguir: 
Quadro 6 - Resumo dos conceitos de língua, linguagem, aprender e ensinar uma LE de BI

\begin{tabular}{|c|c|c|}
\hline Conceitos de Ensinar & Conceitos de Aprender uma LE & $\begin{array}{c}\text { Conceitos de Língua/Língua } \\
\text { Estrangeira }\end{array}$ \\
\hline $\begin{array}{l}\text { Definição dos autores: } \\
\text { transformar a sala de aula } \\
\text { em um espaço sensível à } \\
\text { cultura dos sujeitos que } \\
\text { estão em interação, no qual o } \\
\text { contato entre línguas e } \\
\text { culturas diferentes é } \\
\text { construído através do } \\
\text { diálogo e da constante } \\
\text { reflexão crítica sobre as } \\
\text { proximidades e diferenças } \\
\text { que as caracterizam. }\end{array}$ & 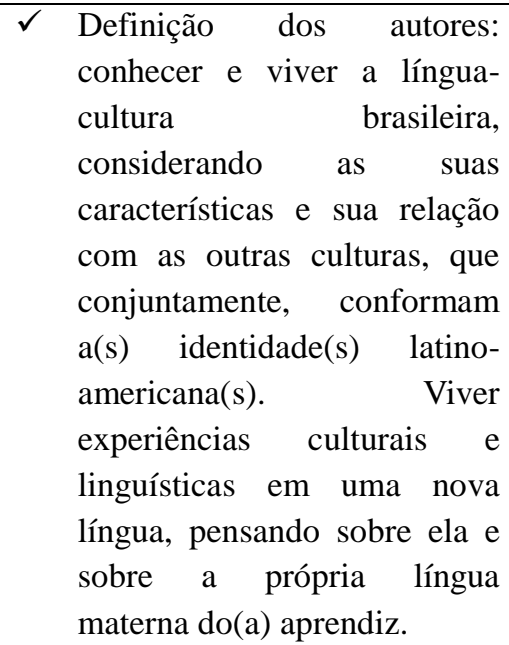 & $\begin{array}{l}\checkmark \text { Definição dos autores: } \\
\text { língua não significa apenas } \\
\text { forma ou sistema, mas um } \\
\text { conjunto de possibilidade } \\
\text { de interação e vivência que } \\
\text { inclui não só estruturas } \\
\text { formais e suas regras, mas } \\
\text { também todos os } \\
\text { significados sociais, } \\
\text { históricos e políticos que a } \\
\text { constituem. }\end{array}$ \\
\hline $\begin{array}{l}\checkmark \text { Definição segundo a análise } \\
\quad \text { de abordagem: } \\
\text { - perguntar } \\
\text { - dar preventivamente conteúdos } \\
\text { de maneira sequenciada, linear } \\
\text { e/ou sistêmica. } \\
\text { - dar atividades para serem feitas } \\
\text { - controlar } \\
\text { - corrigir } \\
\text { - explicar gramática }\end{array}$ & $\begin{array}{l}\checkmark \text { Definição segundo a análise } \\
\text { de abordagem: } \\
\text { - responder perguntas sobre um } \\
\text { texto e dar opinião } \\
\text { - fazer/completar exercícios } \\
\text { - buscar informação e apresentá-la } \\
\text { para os outros aprendizes e o } \\
\text { professor } \\
\text { - identificar conjugações verbais } \\
\text { enquanto se lê } \\
\text { - ouvir e responder } \\
\text { - conversar com os outros } \\
\text { aprendizes sobre o passado, } \\
\text { presente, futuro, sonhos. } \\
\text { - resolver atividades com os } \\
\text { outros aprendizes } \\
\text { - escrever } \\
\text { - identificar, classificar } \\
\text { selecionar sons fonéticos } \\
\text { - ler } \\
\text { - simular } \\
\text { - brincar } \\
\text { - relacionar } \\
\text { - cantar } \\
\text { - discutir }\end{array}$ & $\begin{array}{l}\checkmark \quad \text { Definição segundo a } \\
\text { análise de abordagem: } \\
\text { - estruturas, sistema, sons, } \\
\text { vocabulário } \\
\text { - cultura } \\
\text { - história } \\
\text { - economia } \\
\text { - instrumento para se comunicar } \\
\text { - Textos, áudios, vídeos } \\
\text { autênticos }\end{array}$ \\
\hline
\end{tabular}

Os papéis e atitudes de aprendizes e professores (ALMEIDA FILHO, 1997) que esse LD faz transparecer são: 


\section{Quadro 7 - Papéis e atitudes do professor e do aprendiz implícitos no MD "Brasil Intercultural"}

\begin{tabular}{|c|c|}
\hline Professor & Aprendiz \\
\hline $\begin{array}{c}\text { Direcionador de conteúdos e } \\
\text { atividades (P)* }\end{array}$ & Interlocutor (P) \\
\hline Controlador (P) & Participante (A/P) \\
\hline Observador (P) & Respondedor (P/A) \\
\hline Passivo (A) & Solucionador (P/A) \\
\hline Questionador (P) & Apresentador (P) \\
\hline
\end{tabular}

* (A) Atitude - (P) Papel

Nos quadros 5, 6 e 7 predominam traços característicos, conceitos de língua, linguagem, ensinar e aprender uma LE e papéis e atitudes de professores e aprendizes oriundos de duas abordagens distintas: uma gramatical e outra comunicativa. Por outro lado, a abordagem declarada pelos autores não é exatamente a identificada por meio da análise aqui proposta. Os autores declaram o material como "intercultural" e segundo minha análise de abordagem ele é "pré-comunicativo com forte presença da abordagem gramatical e alguns traços característicos da abordagem comunicativa”.

Nesse sentido, Viana (1997), afirma que alguns professores declaram ser comunicativos e em sua prática transparece uma abordagem gramatical. Segundo esse autor, isso acontece porque a abordagem se instala nos agentes participantes da grande operação de ensinar e aprender línguas por meio da tradição, do caráter nacional e da cultura de ensinar e aprender. O mesmo autor (op.cit) continua afirmando que é a abordagem que escolhe os agentes.

Assim, no caso do MD Brasil Intercultural, é possível levantar a hipótese de que a abordagem implícita no material é uma equação produto da tensão de abordagens $^{8}$ (ALMEIDA FILHO, 1993, RIBEIRO, 2008 ) dos próprios autores com os outros agentes envolvidos na OGEL. Quero dizer que, talvez, para compor esse material os autores tiveram de fazer concessões aos professores que iam usar o material didático, à tradição, ao caráter nacional e à cultura de aprender e de ensinar do público alvo desse material e à instituição a qual todos esses agentes estão filiados.

\footnotetext{
${ }^{8}$ Tensão entre abordagens: oposição competitiva de distintas abordagens uma frente a outra(s) numa dada situação de ensino e aprendizagem de língua(s); a não harmonia entre as diferenças nas abordagens que ocasiona um grau de conflito a ser resolvido por uma equação de abordagem (Glossário de LA, www.glossario.sala.org.br/)
} 
Essa inferência respalda-se em Almeida Filho (1993) por esse autor afirmar que a não convergência da abordagem do aluno com a do professor ou do LD poderia acarretar problemas, como resistência e dificuldade do aluno em relação à aprendizagem da LE, podendo levar ao desânimo e até mesmo ao fracasso no aprendizado (vide Freitas, 2008). Quero dizer com isso, fazendo uma analogia dessas assertivas com o caso analisado em BI, que a não convergência da abordagem dos autores com a dos professores, alunos usuários do LD, escola de línguas e outros agentes poderia acarretar problemas, como resistência e dificuldade do aluno e do professor para enxergar o livro didático como um dos recursos válidos para a difícil tarefa de aprender uma nova língua. Por isso os autores, fizeram essas concessões.

A analogia anterior também se justifica em Almeida Filho (1993, p. 13) que considera a abordagem de um professor não como a única força atuante na construção do processo de ensino e aprendizagem. Além dela, coexistem a abordagem de aprender do aluno, a de ensino subjacente ao MD e os valores desejados por outros agentes que permanecem ou influenciam o ambiente escolar. Na página 56 desta dissertação, Capítulo Teórico, na Figura 6, há uma representação, num quadro sinótico elaborado por Almeida Filho (1994, p.45), com indicação de todas as forças que atuam no quadro da relação professor-aprendiz com o LD como mediador junto da abordagem do produtor do LD.

Além disso, ainda que contrastar a abordagem declarada pelos autores com a abordagem elucidada não fosse um dos objetivos desta pesquisa, durante $\mathrm{o}$ desenvolvimento da mesma, vi a necessidade de interpretar esse conflito. A coordenadora do material didático, a Prof. Dra. Edleise Mendes, em sua tese de doutorado propõe a Abordagem Comunicativa Intercultural (ACIN) ${ }^{9}$ como um caminho para ensinar e aprender língua no diálogo de culturas (MENDES, 2004). No entanto, como verificado por meio da análise, a abordagem predominante no LD Brasil Intercultual não é exatamente a "abordagem intercultural", declarada pela coordenadora e defendida na sua tese de doutoramento. Uma reflexão pertinente para esse conflito de abordagens é: se os autores fizeram concessões de princípios de sua abordagem para princípios da abordagem de professores, alunos e instituições para os quais esses LD

\footnotetext{
9 Abordagem Comunicativa Intercultural: [...] pode ser resumida como a força potencial que pretende orientar as ações de professores, alunos e de outros envolvidos no processo de ensino/aprendizagem de uma nova língua-cultura, o planejamento de cursos, a produção de materiais e a avaliação da aprendizagem, com o objetivo de promover a construção conjunta de significados para um diálogo entre culturas (MENDES, 2004, p. 153).
} 
são produzidos talvez devam declarar essas concessões também na apresentação da obra.

Essa abordagem proposta por Mendes (2004) tem embasamento teórico na noção de "competência comunicativa intercultural" que surgiu em expansão da competência comunicativa. Byram (1997) defende que o aprendiz de novas línguas precisa desenvolver uma competência que difere qualitativamente da competência desenvolvida por falantes nativos ao participar de grupos e/ou comunidades sociais. $\mathrm{O}$ conceito de "competência comunicativa intercultural" apontado por esse autor distingue os conhecimentos e habilidades que usuários de mais de uma língua desenvolvem ao participar de atividades e situações e que a língua-alvo é código habitual utilizado por aqueles com línguas preferenciais diferentes. Para Almeida Filho (1993. p. 9), a "competência intercultural" (ou sociocultural) é um dos componentes da "competência comunicativa" e não uma abordagem de ensino e aprendizagem.

\section{LD Horizontes}

Quanto ao LD "Horizontes", nele predominam atributos característicos da abordagem comunicativa na configuração das unidades, insumo e atividades com forte presença de atividades pré-comunicativas que colocam professores e aprendizes em papéis e atitudes ainda tradicionais para a abordagem comunicativa. Em menor quantidade, o MD proporciona atividades de cunho gramatical/estrutural, a modo de revisão, o qual não condiciona o julgamento da abordagem predominante já que a gramática tem um papel complementar, coadjuvante no livro como um todo.

Trata-se de um livro predominantemente comunicativo que ainda não pode ser declarado como totalmente mergulhado nos traços característicos da abordagem comunicativa pela forte presença de atividades pré-comunicativas, ou seja, atividades em transição, entre a abordagem gramatical e a comunicativa as quais deixam o próprio MD em estado de passagem, transição, de uma abordagem mais preocupada com o estudo da língua para outra centrada na comunicação, que prepara o aprendiz para situações de comunicação futuras, para uma abordagem voltada ao ensino e aprendizagem de LE que promove a construção do significado como ponto de partida para a configuração das experiências do aprender e ensinar. 
A seguir, um quadro resumo dos traços característicos do MD Horizontes que permitiram asseverar qual abordagem predomina nele:

Quadro 8 - Traços característicos de abordagem do LD Horizontes

\begin{tabular}{|c|c|c|}
\hline & \multicolumn{2}{|c|}{ Traços característicos de Abordagem } \\
\hline \begin{tabular}{|l} 
Indicadores \\
constitutivos
\end{tabular} & Abordagem comunicativa & Abordagem gramatical \\
\hline Unidades & $\begin{array}{l}\text { - promovem a aprendizagem da língua } \\
\text { por meio de tópicos do mundo } \\
\text { moderno. Os tópicos não são trazidos } \\
\text { propositalmente porque priorizam o uso } \\
\text { de certas estruturas e vocabulário, mas } \\
\text { porque por meio do aprendizado deles } \\
\text { se produz um esforço significativo de } \\
\text { adquirir um novo conhecimento usando } \\
\text { uma nova língua que também é alvo de } \\
\text { aprendizagem. }\end{array}$ & \\
\hline Atividades & $\begin{array}{l}\text { - } 28 \% \text { das atividades (Produção de } \\
\text { gêneros textuais, tarefas, leituras } \\
\text { extensivas, jogos) tem como elemento } \\
\text { organizador das experiências o foco na } \\
\text { produção de significados, a resolução } \\
\text { de um problema. }\end{array}$ & $\begin{array}{l}\text { - } 36 \% \text { das atividades tem como ponto de } \\
\text { partida um conteúdo de gramática, fonética, } \\
\text { vocabulário, ou seja, em que a língua quanto } \\
\text { sistema é o conceito que define a natureza } \\
\text { das experiências promovidas nas atividades. } \\
\text { No entanto, as atividades de gramática são } \\
\text { apresentadas no livro como de "revisão". } \\
\text { - } 36 \% \text { das atividades são pré-comunicativas } \\
\text { (5 tipos): seguem o formato tradicional de } \\
\text { pergunta e resposta (BARBIRATO, 1999), } \\
\text { sem necessariamente em todos os casos } \\
\text { estarem direcionadas ao uso/prática de } \\
\text { determinados conteúdos, mas dão trilhos } \\
\text { para os alunos solucionarem a atividade o } \\
\text { qual de alguma maneira tira o foco da } \\
\text { construção de sentido. }\end{array}$ \\
\hline Insumo & $\begin{array}{l}\text { - boa quantidade e qualidade em } \\
\text { diversos gêneros textuais (orais, escritos } \\
\text { e multimodais) com cortes e } \\
\text { adaptações, de fontes autênticas (reais) } \\
\text { como internet, jornais, revistas, CDs, } \\
\text { entre outros. }\end{array}$ & \\
\hline
\end{tabular}

Em Horizontes, os conceitos implícitos sobre aprender, ensinar uma LE e sobre língua e linguagem foram explicitados no quadro a seguir também em contraste com esses mesmos conceitos declarados pelos autores na apresentação do LD: 
Quadro 9 - Resumo dos conceitos de língua, linguagem, aprender e ensinar uma LE de Horizontes

\begin{tabular}{|c|c|c|}
\hline Conceitos de Ensinar & $\begin{array}{l}\text { Conceitos de Aprender uma } \\
\text { LE }\end{array}$ & $\begin{array}{l}\text { Conceitos de Língua/Língua } \\
\text { Estrangeira }\end{array}$ \\
\hline $\begin{array}{l}\checkmark \text { Não há uma definição dos } \\
\text { autores para o conceito de } \\
\text { ensinar. }\end{array}$ & $\begin{array}{l}\text { Definição dos autores: } \\
\text { aprender vocabulário e } \\
\text { gramática não é suficiente. } \\
\text { Desenvolvimento das } \\
\text { habilidades comunicativas, } \\
\text { integração de competências. } \\
\text { (gramatical, sociolinguística, } \\
\text { textual-discursiva, } \\
\text { estratégica), diálogo } \\
\text { intercultural e intercâmbio } \\
\text { de experiências } \\
\text { interculturais. }\end{array}$ & $\begin{array}{l}\text { Definição dos autores: } \\
\text { língua como cultura e lugar } \\
\text { de interação, que também } \\
\text { privilegia o foco no sentido. } \\
\text { A gramática é instrumental }\end{array}$ \\
\hline $\begin{array}{l}\text { Definição segundo a análise } \\
\text { de abordagem: } \\
\text { - corrigir exercícios } \\
\text { - selecionar aprendizes para } \\
\text { representar papéis } \\
\text { - ouvir discussões e } \\
\text { apresentações dos alunos } \\
\text {-explicar conteúdos } \\
\text { gramaticais de revisão } \\
\text { - mediar } \\
\text { - dar temas para buscar } \\
\text { informação }\end{array}$ & $\begin{array}{l}\checkmark \text { Definição segundo a análise } \\
\text { de abordagem: } \\
\text { - aprender sobre temas do mundo } \\
\text { contemporâneo } \\
\text { - revisar estruturas fazendo } \\
\text { exercícios } \\
\text { - responder perguntas sobre um } \\
\text { texto e dar opinião } \\
\text { - buscar informação e apresentá- } \\
\text { la para os outros aprendizes e o } \\
\text { professor } \\
\text { - ouvir e responder } \\
\text { - resolver problemas com os } \\
\text { outros aprendizes } \\
\text { - escrever } \\
\text { - fazer leituras extensivas } \\
\text { - desempenhar papéis } \\
\text { - brincar } \\
\text { - cantar } \\
\text { - discutir } \\
\text { - argumentar }\end{array}$ & $\begin{array}{l}\checkmark \text { Definição segundo a análise } \\
\text { de abordagem: } \\
\text { - cultura } \\
\text { - valores } \\
\text { - música } \\
\text { - comunicação } \\
\text { - sistema de estruturas } \\
\text { - consenso } \\
\text { - intercâmbio de ideias }\end{array}$ \\
\hline
\end{tabular}

Os papéis e atitudes de aprendizes e professores (ALMEIDA FILHO, 1997) que esse LD faz transparecer são: 


\section{Quadro 10 - Papéis e atitudes do professor e do aprendiz implícitos no MD "Horizontes"}

\begin{tabular}{|c|c|}
\hline Professor & Aprendiz \\
\hline Selecionador (P) & Debatedor (P/A) \\
\hline Controlador (P) & Participante (P/A) \\
\hline Observador (P) & Leitor (P) \\
\hline Participante (A) & Interlocutor (P) \\
\hline Questionador (P) & Apresentador (P) \\
\hline
\end{tabular}

* (A) Atitude - (P) Papel

Nos quadros 8, 9 e 10 subjazem traços característicos, conceitos de língua, linguagem, ensinar e aprender uma LE e papéis e atitudes de professores e aprendizes predominantemente oriundos da abordagem comunicativa e em segundo plano précomunicativos. Assim como em BI, as autoras deste material declaram na apresentação que se trata de um livro produzido em torno dos princípios da "abordagem intercultural" de Mendes (2004). No entanto, assim como em BI, a abordagem declarada não é exatamente a identificada por meio da análise, ainda que a divergência entre os traços característicos da abordagem declarada pelos autores e a identificada seja menor do que em BI.

Uma das autoras de Horizontes é a atual diretora da escola de PLE (Instituto Horizontes) na Argentina e a outra é professora da instituição também para a qual o livro foi criado. Talvez por esse motivo haja menos concessões de princípios de abordagem já que as autoras são professoras e uma delas diretora. As afirmações anteriormente expostas de Viana (1997) e Almeida Filho (1993, 1997, 2012) sobre a tensão de forças potenciais que se fazem presentes na OGEL como consequência dos diferentes agentes envolvidos na grande operação de ensinar línguas respaldam essa inferência, pois neste caso há menos divergência entre a abordagem declarada e a analisada, entre as bases teóricas dos conceitos de língua, linguagem, aprender e ensinar uma LE e entre os papéis e atitudes de aprendizes e professores pelo fato de os produtores do material (terceiros agentes), também serem agentes (professora e diretora) da instituição ao qual esse material didático é filiado.

Por último, em se tratando de abordagem, é possível fazer projeções de como podem confluir as abordagens desses materiais durante o uso por professores filiados a 
outras abordagens que não exatamente as implícitas nos livros em questão. BI pode ser transformado num livro totalmente gramatical, se empregado por um professor da abordagem gramatical, pois o livro guarda muitos traços característicos dessa abordagem no planejamento implícito, na configuração das unidades e atividades. Se um professor comunicativo tiver de trabalhar com esse didático, pode ter de fazer muitas adaptações, principalmente nas atividades que levam ao foco constante na forma. No caso de Horizontes, um professor gramatical pode sentir falta de listas de conjugações verbais, teoria sobre tópicos da estrutura linguística e tratamento acentuado à prática da forma, pois a configuração das unidades e de $28 \%$ das atividades acontece em torno dos princípios da abordagem comunicativa.

Cabe destacar que as coleções de didáticos analisadas foram chamadas de LD e MD indistintamente por questões estilísticas para não incorrer em repetições. Não obstante, na fundamentação teórica deste trabalho de dissertação (Tabela 1, p. 30) esclareceu-se a diferença entre o conceito de Livro Didático e Material didático. Por isso, se faz necessário explanar que Brasil Intercultural abriga características de LD e Horizontes de MD. Enquanto BI está preconcebido sequencialmente por conteúdos de gramática, vocabulário, pronúncia, funções, leitura, escrita, áudios, exercícios para serem seguido pelos professores e alunos, Horizontes gera oportunidades constantes de comunicação na nova língua e deixa muito espaço para ser complementado pelas ações de professores e aprendizes, LD e MD respectivamente.

Como visto, a análise de abordagem também permite discernir que tipo de didático disponíveis no momento de selecionar materiais para a arena de ações do ensinar uma nova língua. Durante este capítulo, compus a análise de abordagem dos materiais argentinos pensando em que professores poderiam adotar esse procedimento para selecionar os didáticos previamente ao uso e para refletir sobre sua própria abordagem e a de terceiros. Ainda que a análise mostre resultados relevantes da faceta “processos de criação", como já disse em capítulos anteriores, não é a análise em si o fim primeiro da pesquisa relatada nesta dissertação. 


\section{CONSIDERAÇOES FINAIS}

No início deste trabalho, delineei três objetivos que, junto com as perguntas de pesquisa, foram conduzindo a construção da fundamentação teórica, metodológica e a análise dos registros. Apresentei o cenário atual de ensino de PLE na Argentina até chegar ao ano 2010, com a produção independente de didáticos para o ensino dessa língua. Analisei a abordagem das obras dos materiais didáticos mais representativos, sempre tentando não perder de vista os objetivos geral, específicos e as perguntas de pesquisa. A análise documental e às questões criadas por meio do procedimento de análise de abordagem, permitiram alcançar os resultados esperados.

A análise de abordagem permitiu elucidar os traços característicos de abordagem e a base teórica das concepções de língua, linguagem, língua estrangeira, ensinar e aprender uma $L E$ dos didáticos selecionados por meio de questões ligadas a cada um dos indicadores constitutivos (unidades, atividades, insumo e teoria) estabelecidos com o alicerce teórico da literatura disponível sobre a materialidade "material didático". Dessa análise surgiu uma taxonomia de atividades comunicativas, pré-comunicativas e de prática do código linguístico que pode vir a auxiliar a tarefa de adaptação/interpretação de materiais, dos professores de línguas. Cabe salientar que essa taxonomia, além de se alimentar da teoria de linguistas aplicados da AElin, foi extraída de materiais reais em circulação no mercado editorial.

Os traços característicos de abordagem, obtidos por meio das análises e interpretações, em contraste com a abordagem declarada pelos autores dos materiais, deixou clara a necessidade dos profissionais do ensino de LE de adotar analítica e reflexivamente o material que usam para compor a ação ensinadora. Isso significa que não é possível apenas escolher um material didático acreditando na declaração de abordagem feita pelo autor do mesmo.

Além disso, o procedimento de análise de abordagem permitiu elucidar os papéis e atitudes de alunos e professores implícitos nos LDs analisados. Por meio dele, também foi possível verificar o tipo de material didático que cada um dos livros representa, "Livro Didático" ou "Material didático". Por outro lado, a análise da 
natureza organizadora das unidades revelou o tipo de planejamento implícito no material.

Essas evidências me permitem reafirmar a proposta feita durante este trabalho de pesquisa quanto ao procedimento de análise de abordagem como um caminho válido para adotar/selecionar/avaliar materiais didáticos para o ensino e aprendizagem de línguas estrangeiras. A composição do texto desta dissertação foi pensada para ser lida por professores, já que a análise e interpretação dos registros, junto ao marco teórico, foram motivados pela ideia de constituir um "Guia de adoção/seleção/avaliação de material didático para o ensino de línguas estrangeiras para professores baseado no procedimento de análise de abordagem”.

Não se trata de uma check list ou de uma receita pronta, mas de Teoria sobre a força que comanda toda a operação de ensinar uma outra língua: a abordagem dos materiais didáticos ou livros didáticos que selecionamos para configurar essa grande operação de aprender e ensinar. Trata-se de um procedimento diferenciado para a adoção dos materiais didáticos que traz mais do que a seleção dos mesmos.

O capítulo teórico e de análise de registros contêm o cerne teórico e procedimental de base para testar a análise de abordagem como guia até a escolha de MDs previamente ao seu uso. Por meio desse tipo de análise, o professor não apenas escolhe o material didático que o auxiliará durante o curso, mas também reflete sobre sua abordagem, a abordagem e cultura de aprender dos outros agentes (alunos, instituição, famílias) envolvidos na OGEL. Essa reflexão também constitui um meio mais consciente de trabalhar rumo à harmonização das abordagens envolvidas em todo o processo de ensinar e aprender que consequentemente levam a ampliar as possibilidades de sucesso na aprendizagem da língua-alvo.

De maneira mais sutil, este trabalho contribui com vários verbetes para o Glossário de Linguística Aplicada (GLOSSA), por exemplo, o termo "leitura extensiva". Ao mesmo tempo esse é um tópico para outras investigações: a leitura extensiva como deflagradora de prática comunicativa em cursos de línguas.

Analisar o material didático separadamente das aulas foi parte da delimitação da pesquisa. Durante o uso os didáticos podem ser reinterpretados (adaptados) pelo professor, assim como o regente de uma orquestra o faz com uma partitura. No entanto, ainda que com essa delimitação, o procedimento proposto permite:

a- Elucidar conceitos de língua, linguagem, LE, aprender e ensinar uma LE. 
b- Contrastar a abordagem declarada pelos autores com a abordagem realmente implícita.

c- Refletir sobre a própria abordagem e a de terceiros agentes para saber se esse material se adequa à situação/contexto de ensino em que o professor vai operar.

d- Enxergar papéis e atitudes de alunos e professores que o material traz configurados nas atividades, assim como o tipo de planejamento implícito por meio da análise da natureza organizadora das unidades.

Este trabalho foi delimitado também em função do tempo em que a pesquisa devia acontecer. Por isso, não foi possível testar a proposta, o procedimento de análise de abordagem para selecionar didáticos por professores de línguas. Essa poderia ser a segunda parte desta dissertação, ou seja, um tópico para outra pesquisa, ou ainda para um trabalho de doutorado. A meu ver, ainda é necessário revisar e pensar em outros indicadores de abordagem além de unidades, atividades e insumo para avaliar se um material se adequa ao contexto de ensino. Além disso, para um professor usar esse procedimento, precisa ter formação no construto de abordagem.

Embora a análise de um MD não seja tarefa simples, nesta pesquisa desenvolvi um procedimento de análise que pudesse auxiliar professores na escolha/seleção/adoção/avaliação prévia ao uso de materiais didáticos, pois por meio do construto de análise de abordagem de Almeida Filho. O procedimento em si, proporciona mais do que uma análise para seleção de MD, por meio dele podemos nos deparar com as limitações do próprio material, de seus autores e de nós mesmos como agentes da OGEL. Como consequência, discernir todas ou algumas dessas limitações pode acarretar mudanças ou atualização de conhecimentos, habilidades, posturas e atitudes de ensinar uma outra língua com toda a complexidade que isso representa, a falantes de outras línguas e, também, entender toda a complexidade do processo de aprender uma LE.

Esta dissertação será colocada à disposição das escolas que usam os livros didáticos estudados nas quais professores podem usufruir desta análise.

Vejo a análise de abordagem para a adoção de MDs como um procedimento, por um lado, funcional, pois dá ferramentas para resolver uma das quatro tarefas na vida profissional dos professores e, por outro lado, enriquecedor, dado que junto da seleção de um didático é possível refletir sobre a própria abordagem e a de terceiros, reflexão essa que conduz o professor a querer desenvolver-se, desenrolar-se e auxiliar os aprendizes a se desenvolverem, mote primeiro deste trabalho de pesquisa. 


\section{REFERÊNCIAS}

ANTHONY, E. M. Approach, Method, Technique. English Language Teaching (ELT Journal), v. 17, n. 2, p. 63-67, 1963.

ALMEIDA, V. P. de. Conhecendo as regras do jogo: a competência comunicativa e os manuais didáticos de ensino de inglês como língua estrangeira. Tese de doutorado. Programa de Pós Graduação em Linguística. Universidade de Brasília, 2011

ALMEIDA FILHO, J.C.P. Quatro estações no ensino de línguas, Pontes, 2012.

. Dimensões comunicativas no ensino de línguas. Campinas,

Pontes, 1993.

Codificar conteúdos, processo e reflexão formadora no material didático para ensino e aprendizagem de línguas. In: LOPES, A.,\& GOTHEIM, L. (Org). Materiais didáticos para o ensino de línguas estrangeiras: processos de criação e contextos de uso. Campinas, SP: Mercado de Letras, 2013.

Escolha e produção de material didático para o ensino de línguas comunicativo. Contexturas, Vol.. 2 1994, APLIESP, SP.

Raízes do ensino Comunicativo de línguas, In: Revista HELB, Ano $^{\circ} 3$ 1/2009, disponível em http://helb.org.br. Acesso em: março 2012.

- Questões da interlíngua de Aprendizes de Português a Partir ou com a Interposição do Espanhol (Língua muito próxima), in SIMÕES, A. R. M.; CARVALHO, A; WIEDEMANN, L (Orgs). Português para Falantes de Espanhol, USA/BRASIL, Campinas, Pontes, 2004.

"A abordagem orientadora da ação do professor". In: ALMEIDA FILHO, J.C.P. (Org.). Parâmetros Atuais no Ensino de Português Língua Estrangeira. Campinas: Pontes, 1997.

Português para estrangeiros: interface com o espanhol. ALMEIDA FILHO, J.C.P. (Org.). Campinas, SP: Pontes, 1995.

ALMEIDA FILHO, J. C. P \& BARBIRATO, R. C. Ambientes comunicativos para aprender Língua Estrangeira. In: Trabalhos de Linguística Aplicada, Campinas: Editora da Unicamp, (vol. 36): 23-42, Jul./Dez.2000.

ALMEIDA FILHO, J.C.P. LOMBELLO, L. C. (orgs). Identidade e caminhos no ensino de Português para estrangeiros, Campinas (SP), Pontes, Editora da Universidade Estadual de Campinas, 1992.

ALMEIDA FILHO, J.C.P., BAGHIN, D., CONSOLO, D., et al. A representação do processo de aprender no Livro Didático Nacional de Língua Estrangeira Moderna no $1^{\circ}$ Grau. Trabalhos em Linguística Aplicada, Campinas (17), págs. 67-97, 1991. 
APPOLINÁRIO, F. Dicionário de metodologia científica: um guia para a produção do conhecimento científico. São Paulo, Atlas, 2009.

ARAGÃO MELO, F., Há algo em jogo nesse jogo: o uso do lúdico como atividade significativa na interação comunicativa no ensino-aprendizagem do Espanhol como LE no ciclo juvenil. Dissertação de Mestrado. Programa de Pós Graduação em Linguística Aplicada, Universidade de Brasília, 2013.

ARGENTINA, Dirección de Lenguas extranjeras del Ministerio de Educación de Gobierno de la ciudad de Buenos Aires. Programa "Lenguas en los Barrios". Disponível em:

http://www.buenosaires.gob.ar/areas/educacion/niveles/idiomas/lenguas_en_los_barrios .php?menu_id=23075. Acesso em: junho de 2014

ARGENTINA, Núcleos de aprendizaje prioritário (NAP), Ministerio de Educación, Ciencia y Tecnología. Disponível em: http://www.me.gov.ar/curriform/nap.html. Acesso em: abril 2012

ARGENTINA, Ley N 26.468, Ministerio de Educación Ciencia y Tecnologia, Boletín oficial, 2008 disponível em http://www1.hcdn.gov.ar/dependencias/ceducacion/leyes/26468.html Acesso: Maio de 2012

ARGENTINA, Ley Federal de Educación, Ley No 24.195, Ministerio de Educación Ciencia y Tecnología, $1993 . \quad$ Disponível em: http://www.me.gov.ar/consejo/cf_leyfederal.html, Argentina. Acesso em: abril 2012

ARGENTINA, Ley de Educación Nacional, Ley N 26.206, Ministerio de Educación Ciencia y Tecnología, 2006, Disponível em: http://www.me.gov.ar/doc_pdf/ley_de_educ_nac.pdf . Acesso em: julho de 2012.

ARNOUX, E. N. de., "Reflexiones glotopolíticas en torno a la integración sudamericana". Disponível em: http://www.scribd.com/ARNOUX-ReflexionesGlotopoliticas-en-Torno-a-La-Integracion-Sudamericana/d/7030207, 2007. Acesso em: junho de 2012

BARBIRATO, R. C. de. A tarefa como ambiente para aprender. Dissertação de Mestrado. Universidade de Campinas, São Paulo, 1999.

BEIN, Roberto. La situación de las lenguas extranjeras en Argentina. Buenos Aires, Argentina, UFBA, 2012. Disponível em: http://www.linguasur.org.ar/panel/archivos/f9227ef50db3de732e1d3f897de85aa8Bein\% 20lenguas\%20extranjeras.pdf . Acesso em: abril de 2013

BELL, T. Extensive Reading: Why? and How? The Internet TESL Journal, Vol. IV, No. 12, 1998. Disponível em: http://iteslj.org/Articles/Bell-Reading.html. Acesso em: 22 de outubro de 2014.

BOGDAN, R. C. \& BIKLEN, S. K. Qualitative research for education: an introduction to theory and methods. Needham Heights, MA: Allyn \& Bacon, 1998. 
BRASIL. Guia de livros didáticos: PNLD 2012, Língua Estrangeira Moderna. Brasília: Ministério da Educação, Secretaria de Educação Básica, 2011.

BRASIL. Protocolos e tratados bilaterais, in DAI - Divisão de Atos Internacionais, Ministério das Relações Exteriores, Atas Internacionais 2005. Disponível em: http://daimre.serpro.gov.br/atos-internacionais/bilaterais/2005/b_221/ . Acesso em: maio 2012.

BREEN, M. P. e CANDLIN, C. N. The Essentials of a Communicative Curriculum in Language Teaching. Applied Linguistics 1(2),1980: 89- 112.

BREEN, M.; CANDLIN, C. e WATERS, A. Produção de materiais comunicativos:alguns princípios básicos. Trabalhos em Linguística Aplicada, Campinas, págs. 39-52, Jul/Dez. 1998. Disponível em: http://revistas.iel.unicamp.br/index.php/tla/article/view/2422/4637. Acesso em: fevereiro de 2014.

BYGATE, M., SKEHAN, P. \& SWAIN, M., (eds.) Researching pedagogic tasks, second language learning, teaching and testing. In: Applied Linguistics and Language Study. Harlow: Longman, 2001.

BYRAM, M. Teaching and Assessing Intercultural Communicative Competence. Clevedon: Multilingual Matters. 1997

CASTRO, F.T; GONZÁLEZ, V.A.; ALARCÓN, Y.G.L.; CURADELLI, A. As línguas do ABC: $\mathrm{O}$ antes e o depois do MERCOSUL na história do ensino de PLE na Argentina e no Chile e de ELE no Brasil, artigo produzido para a disciplina História do Ensino de Línguas no Brasil (HELB), PPGLAđnB, Brasília: 2013 (digitado).

CANDLIN, C. N. \& MURPHY, D., (eds.) Language Learning Tasks. Englewood. Cliffs N. J.: Prentice Hall International, 1987.

CELLARD, A. A análise documental. In: POUPART, J. et al. A pesquisa qualitativa: enfoques epistemológicos e metodológicos. Petrópolis, Vozes, 2008.

CONTURSI, María Eugenia. Política y planificación lingüística en los primeros 10 años del Mercosur: el portugués en Argentina, Revista SIGNOS ELE, $N^{\circ}$ 6, 2012. Disponível em: http://www.salvador.edu.ar/sitio/signosele/, [PDF, pp. 1-26]. Acesso em: abril de 2012.

CORACINI, M. J. R. F. O Livro didático nos discursos da linguística aplicada e da sala de aula. In: CORACINI, M. J. R. F. Interpretação, Autoria e Legitimação do Livro Didático. Campinas, Pontes, 1999.

CRISTOFOLI, Maria Silvia. Políticas de línguas estrangeiras na educação básica, Brasil e Argentina entre avanços e percalços, Tese de Doutorado, Universidade Federal do Rio Grande do Sul, Porto Alegre, 2010. Disponível em: http://www.lume.ufrgs.br/bitstream/handle/10183/26479/000759309.pdf?sequence=1. Acesso em: abril 2012.

CROOKES, G. \& GASS, S. M. Tasks and language learning: integrating theory and practice. Clavedon, Avon: Multilingual Matters, 1993. 
DAY\&BAMFORD, Extensive Reading: What Is It? Why Bother? JALT Journal Publications, $1997 \quad$ Disponível em://www.jaltpublications.org/ttt/files/97/may/extensive.html Acesso em: 22 de outubro de 2014

DIAS, R. Critérios para a avaliação do livro didático de língua estrangeira no contexto do segundo ciclo do ensino fundamental. In: __ _ CRISTÓVÃ̃, V.L.L. O livro didático de língua estrangeira: múltiplas perspectivas. Campinas: Mercado de Letras, 2009. p.199-234

DINIZ, L. R. A. Mercado de línguas: a instrumentalização brasileira do português como língua estrangeira. Dissertação de Mestrado. Campinas, SP, 2008.

DINIZ, L., STRADIOTTI, L. M., SCARAMUCCI, M. V.R. Uma análise de livros didáticos de Português para estrangeiros. In: DIAS, R. e CRISTOVÃO, V. L. O Livro didático de línguas estrangeiras, Múltiplas perspectivas. Campinas, Mercado de Letras, 2009

ELLIS, R. Task-based language learning and teaching. Oxford, UK: Oxford University Press, 2001.

ELLIS, R. The empirical evaluation of language teaching materials ELT Journal Volume 51/1 January 1997. Oxford University Press, 1997.

FERNANDEZ LOPEZ, M. C. Principios y criterios para el análisis de materiales didácticos. In: J. Sanchez Lobato e I. Santos Gargallo (Orgs.), Vademécum para la formación de profesores. Enseñar español como segunda lengua(L2) /lengua extanjera (LE), Madrid: SGEL, 2004. p. 715-731.

FERREIRA, I. A. O processo ensino/aprendizagem de Português língua estrangeira no contexto do MERCOSUL: uma análise de abordagem e metodologia. Dissertação de mestrado, Universidade Estadual de Campinas, 1996.

FIGUEIREDO, N. M. A. Método e metodologia na pesquisa científica. 2a ed. São Caetano do Sul, São Paulo, Yendis Editora, 2007.

FONTÃO DO PATROCÍNIO, E. M. Os bastidores do processo de ensino/ aprendizagem: uma análise de abordagem de ensino em sala de aula de LE. Revista Letras vol. $10 \mathrm{n}^{\text {o }} 1$ e 2, Campinas: PUCCAMP, 1991.

FRANZONI, P. "La enseñanza del portugués. Situación actual”. En I Reunión de la Universidad de Buenos Aires sobre Políticas Linguiísticas. Buenos Aires, Instituto de Lingüística, UBA, 1999.

FREEBODY, P. Qualitative research in education: interaction and practice. London: Sage, 2003.

FREITAS, M. Daquilo que Sabemos: pesquisa metateórica sobre abordagem de ensino de línguas. Dissertação de mestrado. Departamento de Línguas Estrangeiras e Tradução, PPGLA, Universidade de Brasília, Brasília, 2013. 
GALLIMORE, R. \& GOLDBENRG, C. Activity settings of literacy: home and School factors in children's emergent literacy. IN: FORMAN, E. et al. (eds.). Contexts for learning: sociocultural dynamics in children's development. Oxford: Oxford University Press, 1993.

GARDNER, R. C. \& LAMBERT, W. Attitudes and Motivation in Second Language Learning, Rowley, MA: Newbury House Publishers, 1972.

GIL, Gloria (UFSC), "O ensino do inglês, do português e do espanhol como línguas estrangeiras no Brasil e na Argentina: uma comparação glotopolítica", in Revista HELB, Ano ${ }^{\circ} 3$ 1/2009, disponível em http://helb.org.br.

GIL, A. C. Como elaborar projetos de pesquisa. 3.ed. São Paulo: Atlas,1991.

GLOSSÁRIO DE LINGÜÍSTICA APLICADA (Projeto GLOSSA). Glossário digital de termos da Área de Aquisição e Ensino de Línguas. Programa de Pós-Graduação em Linguística Aplicada da UnB, Brasília/DF. Acesso pela Página do PGLA www.pgla.unb.br ou Portal SALA www.sala.orq.br ou www.glossario.sala.org.br

GOMES DE MATTOS, F., Quando a prática precede a teoria: criação do PBE. In: Almeida Filho J. C. P, Lombello, L. C (Orgs.). O ensino de Português para estrangeiros. Campinas, Pontes, 1989

GONZALEZ, V. e SALES HAYASHI, K., Fundamentos, pressupostos e alguns caminhos no ensino de línguas para a aquisição, In: Revista Desempenhos, Ed. 2/2012, Universidade de Brasília, 2014.

GOTTHEIM, L. A gênese da composição de um material didático de português como segunda língua, Tese de doutorado, Campinas, SP: 2007.

GOTTHEIM, L., LOPES PEREIRA, A. Análise de uma unidade para ensino de PLE: expondo os limites e as potencialidade de materiais didáticos e da ação do professor. In: Gotheim, L., Lopes Pereira, A. (Orgs.) Materiais didático para o ensino de língua estrangeira: processos de criação e contextos de uso. Campinas. Mercado de letras, 2013.

JOHNSON, R. B., ONWUEGBUZIE, A. Mixed Methods Research: A Research Paradigm Whose Time has come. Educational Researcher, Volume 33, Number 7, October, 2004, p.14-26.

GUBA, E.G.; LINCOLN, Y.S. Effective evaluation. San Francisco, Jossey-Bass, 1981.

HOWATT, A. P. R. A History of English Language Teaching, Oford, Oxford University Press, 2004

KRASHEN, S. D. Principles and Practice in Second Language Acquisition, Oxford: Pergamon, 1982

KUMARAVADIVELU, B. Understanding Language Teaching: from Method to PostMethod. Kindle ed. Mahwah: Lawrence Erlbaum Associates, Inc., Publishers, 2006. 
LAVILLE, C., DIONNE, J. A., A construção do saber: Manual de metodologia de pesquisa em ciências humanas. Porto Alegre: Armed, Belo Horizonte: Editora UFMG, 1999.

LARSEN - FREEMAN, D. Techiniques and Principies in Language Teaching. Oxford University Press, 1986

LEFFA, V., Metodologia do ensino de línguas. In BOHN, H. I.; VANDRESEN, P. Tópicos em linguística aplicada: O ensino de línguas estrangeiras. Florianópolis: Ed. da UFSC, 1988.

L. G.; LOMBELlO, L. C., BALEEIRO, M. A.; EL-DASH. "Subsídios para a elaboração de material didático para falantes de espanhol" in: Trabalhos em Linguística Aplicada, Campinas, vol. 1, 1983, pp. 117-128.

LONG, M. H. Native speaker / non-native speaker conversation and the negotiation of comprehensible input. Applied Linguistics, Vol. 4, 1983, pp.126-141.

LÜDKE, M.; ANDRÉ, M.E.D.A. Pesquisa em educação: abordagens qualitativas. São Paulo, EPU, 1986.

MORAN, P. R. Teaching Culture: perspectives in practice. Canadá: Heinle \& Heinle, 2001

MENDES, E. Abordagem Comunicativa Intercultural (ACIN), uma proposta para ensinar e aprender língua no diálogo de culturas, Tese de doutorado, IEL, Universidade Estadual de Campinas, SP, 2004.

MERCOSUL, Tratado de Assunção, Tratado Para A Constituição De Um Mercado Comum Entre A República Argentina, A República Federativa Do Brasil, A República Do Paraguai E A República Oriental Do Uruguai. Disponível em: http://www.mercosul.gov.br/tratados-e-protocolos/tratado-de-assuncao-1. Acesso em: abril 2012

MARÍN, M. El enfoque comunicacional para la enseñanza de la lengua. In: MARÍN, M. Lingüística y la enseñanza de la lengua. Buenos Aires: Aique, 2004.

MENDONÇA, S. M. Leitura Extensiva: um elemento motivador para a aprendizagem de línguas estrangeiras. Tese de doutoramento. Faculdade de Letras Universidade do Porto, Portugal, 2012.

MERCOSUR, Plan de acción del Sector Educativo del Mercosur 2011-2015, Puerto Iguazú, Paraguay, 2011. Disponível em: http://sic.inep.gov.br . Acesso em: abril 2012

MERRIAM, S. Qualitative research and case study applications in education. San Francisco: Jossey-Bass, 1998.

MOURA FILHO, A. C. L. Pelo inglês afora: carreira profissional e autonomia na aprendizagem de inglês como língua estrangeira. Brasília, 2005, 281p. Tese (Doutorado 
em Linguística Aplicada). Faculdade de Letras, Universidade Federal de Minas Gerais, 2005.

NUNAN, D. Designing Tasks for the Communicative Classroom. Cambridge: CUP, 1989 . (1991). Language Teaching Methodology: A Textbook For Teachers. London: Prentice Hall.

OLIVEIRA, M. M. Como fazer pesquisa qualitativa. Petrópolis, Vozes, 2007.

O’ NEILL, R. Why use textbooks? ELT Journal, 36, 2, 104-11, 1982. Reprinted in R. Rossner \& R. Bolitho (Eds.). Currents of change in English language teaching . Oxford: OUP, 1990. p. 148-156.

PASERO, C., Una extraña mutación. Lengua portuguesa, educación y literatura en la Argentina 1932-1942, Buenos Aires, Tesis de Maestría Instituto de Altos Estudios Sociales, UNGSM, 2004.

PRABHU, N.S. Second language pedagogy. Oxford: Oxford University Press, 1987.

PRABHU, N. S. Materials as support; materials as constraint. RELC Seminar, Singapore, April 1988.

PRABHU, N. S. The Learner's Effort in the Language Classroom. In: Eugednius Sadtono (ed). Language Acquisition and the Second/Foreign Language Classroom, RELC. Singapore, 1991.

RAMIRO, S. S. El libro de Texto: Selección y Explotación. In: BELLO, P. et al. Didáctica de las Segundas Lenguas. Estrategias y Recursos Básicos. Madrid: Santillana, 1996. p. 109-123

RIBEIRO, T. Forças de abordagem em busca de uma equação de ensinar e aprender LE. Dissertação de Mestrado. PPGLA, Departamento de Línguas Estrangeiras e Tradução, PPGLA, Universidade de Brasília, Brasília, 2007.

RICHARDS, J.C \& RODGERS, T. S. Method: Approach, Design and Procedure. TESOL: Quaterly, vol 16/2, 1982.

RICHARDSON, L. Writing: a method of inquiry. In: Denzin, N. K. \& Lincoln, Y. S. (eds.). Handbook of qualitative research. London: Sage, 1994. pp. 516-529.

ROSSINI, C. The states and challenges of OER in Brazil: from readers to writers? 2009/2010, Disponível em: http://portaldoprofessor.mec.gov.br/storage/materiais/0000012013.pdf. Acesso em: março 2014. 
SÁ-SILVA, J. R et.al, Pesquisa Documental: pistas teóricas e metodológicas, in: Revista Brasileira de História \& Ciências, Número I, 2009. Disponível em: www.rbhcs.com. Acesso em: agosto de 2012.

SANTOS, P., CUNHA, M. C., Ensino e Pesquisa em português para estrangeiros, Programa de Ensino e pesquisa em português para falantes de outras línguas, Editora Universidade de Brasília, 1998.

SANTOS P., O ensino de português como segunda língua para falantes de espanhol: teoria e prática, in Ensino e Pesquisa em português para estrangeiros, Programa de Ensino e pesquisa em português para falantes de outras línguas, SANTOS, P., CUNHA, M. C., Editora UNB, Brasília, 1998.

SANTOS, P., CUNHA, M. C, Tópicos em português língua estrangeira, Editora UNB, Brasília, 2002.

SATELES, L. M. D \& ALMEIDA FILHO, J. C. P. Breve Histórico da Abordagem Gramatical e seus Matizes no Ensino de Línguas no Brasil. In Revista HELB, Ano 4 4/2010. Disponível em http://helb.org.br. Acesso em: março 2013.

SIMÕES, A. R. M.; CARVALHO, A; WIEDEMANN, L (orgs). Português para Falantes de Espanhol, Campinas, Pontes, 2004.

SHELDON, L. Evaluating ELT textbooks and materials. ELT Journal. Volume 42/4 October 1988 - Oxford University Press, 1988

STAKE, R. E., Pesquisa Qualitativa: estudando como as coisas funcionam. Tradução Karla Reis, revisão técnica: Nilda Jacks, Porto Alegre: Penso, 2011.

STERN, H. The communicative syllabus. In Issues and Options in Language Teaching. Oxford: Oxford University Press, 1992.

TOMLINSON, B. (Ed.) Materials development in language teaching. Cambridge: CUP, 1998.

VIANA, N. Planejamento de Cursos de Línguas-Pressupostos e Percurso. In: Parâmetros Atuais para o Ensino de Português Língua Estrangeira. José Carlos Paes de Almeida Filho (Org.) Campinas, SP: Pontes, 1997.

WILLIS, J. A flexible framework for task-based learning. In: WILLIS, R. P. \& WILLIS, J. (eds.) Challenge and change in language teaching. Oxford: Heinemann, 1996.

WILLIS, R. P. \& WILLIS, J. Doing task-based teaching. Oxford, UK: Oxford University Press, 2007.WIDDOWSON, H. G., Teaching Language as Communication, Oxford University Press, 1978 


\section{APÊNDICE}




\section{Apêndice 1 - Instituições de Ensino Superior com "profesorados" de PLE na Argentina por província}

\begin{tabular}{|c|c|c|c|}
\hline Buenos Aires & Córdoba & Mendoza & Corrientes \\
\hline 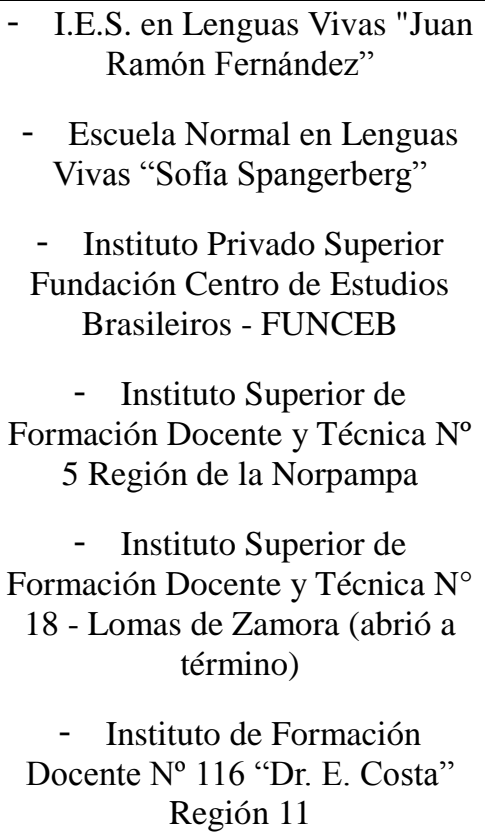 & $\begin{array}{l}\text { - Universidad } \\
\text { Nacional de Córdoba }\end{array}$ & $\begin{array}{l}\text { - Instituto Superior de } \\
\text { Lengua Portuguesa } \\
\text { PT } 156 \text { "Fundación } \\
\text { Brasília" (Gestão } \\
\text { Privada) } \\
\\
\text { - Universidad } \\
\text { Nacional de Cuyo }\end{array}$ & $\begin{array}{l}\text { - Instituto Superior } \\
\text { Josefina Contte } \\
\\
\text { - Instituo de } \\
\text { Formación } \\
\text { Superior Docente } \\
\text { "Ernesto Sábato" }\end{array}$ \\
\hline Entre Rios & Santa Fé & Misiones & Jujuy \\
\hline $\begin{array}{c}\text { - Universidad Nacional de Entre } \\
\text { Ríos - UNER } \\
\text { - Universidad Autónoma de } \\
\text { Entre Ríos - UADER Sede } \\
\text { Paraná y Sede Concepción del } \\
\text { Uruguay }\end{array}$ & $\begin{array}{c}\text { - Universidad } \\
\text { Nacional de Rosario - } \\
\text { UNR }\end{array}$ & $\begin{array}{c}\text { - Universidad } \\
\text { Nacional de } \\
\text { Misiones- UNaM }\end{array}$ & $\begin{array}{c}\text { - Instituto de } \\
\text { Educación Superior } \\
\text { No }^{\circ} \text { - Raúl } \\
\text { Scalabrini Ortiz }\end{array}$ \\
\hline
\end{tabular}

Fonte: Castro, González, Alarcón, Curadelli (2013) 
Apêndice 2 - Linha do tempo sobre alguns acontecimentos que marcaram o ensino de PLE na Argentina

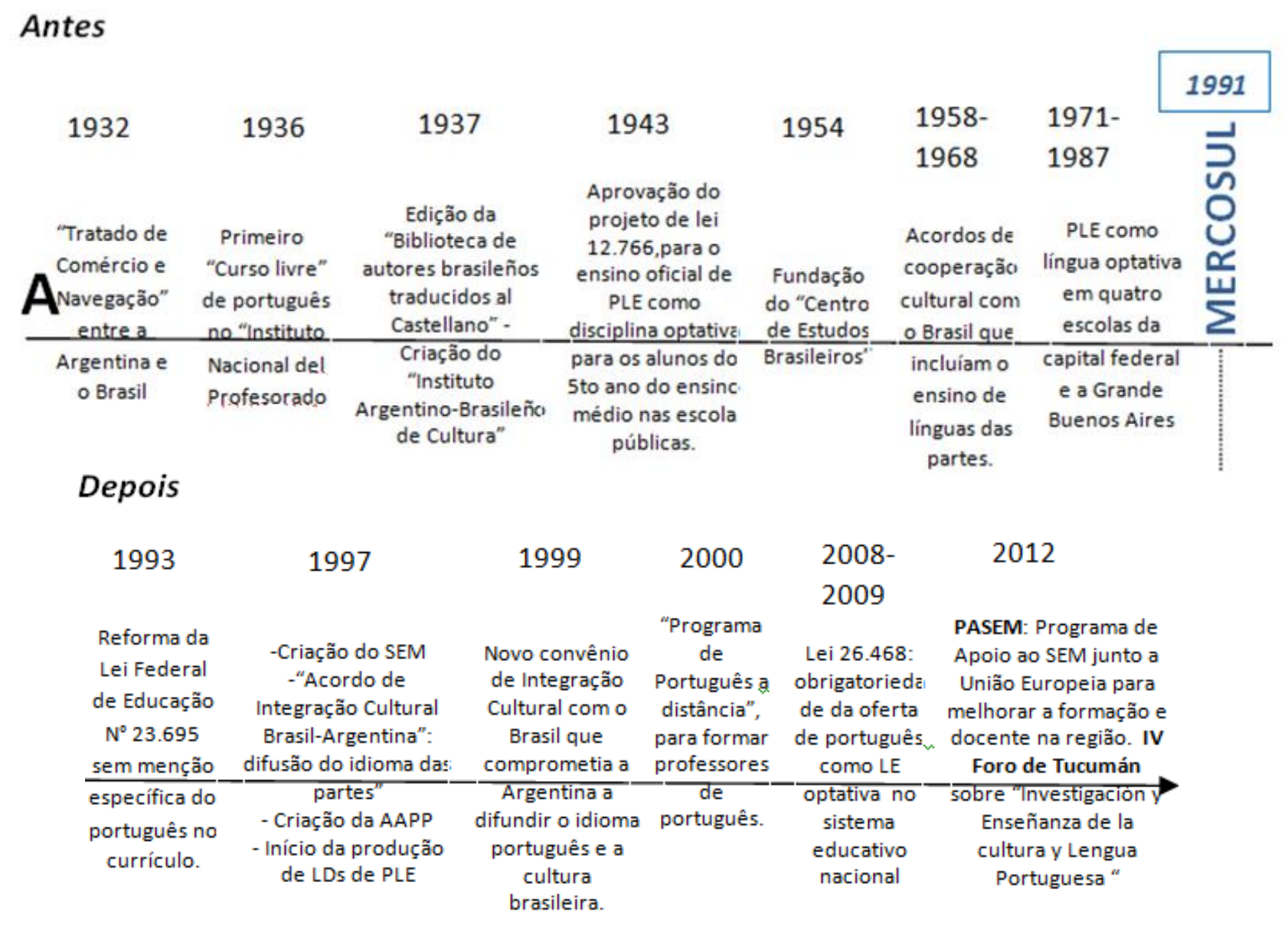

Fonte: Castro, González, Alarcón, Curadelli (2013) 
ANEXOS 
Anexo 1 - Textbook evaluation sheet

FACTUAL DETAILS

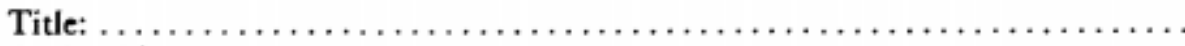

Author(s):

Publisher:

Price:

ISBN: . . . . . . . . . P. Pages:

Components: SB/TB/WB/Tests/Cassettes/Video/CALL/Other

Level $\ldots \ldots \ldots \ldots \ldots \ldots \ldots \ldots \ldots \ldots \ldots \ldots \ldots \ldots$. Physical size: $\ldots \ldots \ldots$

Length: . . . . . Units . . . . . . Lessons/sections . . . . . . Hours . . . . . . .

Target skills: . . . . . . . . . . . . . . . . . . . . . . . . . . . . . . .

Target learners:

Target teachers:

ASSESSMENT (* Poor ** Fair *** Good **** Excellent)

\begin{tabular}{l}
\hline Factor \\
\hline Rationale \\
\hline Availability \\
\hline User definition \\
\hline Layout/graphics \\
\hline Accessibility \\
\hline Linkage \\
\hline Selection/grading \\
\hline Physical characteristics \\
\hline Appropriacy \\
\hline Authenticity \\
\hline Sufficiency \\
\hline Cultural bias \\
\hline Educational validity \\
\hline Stimulus/practice/revision \\
\hline Flexibility \\
\hline Guidance \\
\hline Overall value for money
\end{tabular}

Fonte: Sheldon (1998) 
Anexo 2 - Roteiro para selecionar livros e outros materiais didáticos

\section{Necessidades dos alunos}

$\S \quad$ Foram sondadas previamente através de pesquisa, entrevista ou observação as necessidades dos alunos?

\section{Objetivos}

$\S \quad$ Foram contrastados os objetivos que são propostos no livro (lendo a introdução ou o índice de objetivos) com os que propomos?

$\S \quad$ Quais coincidem?

$\S \quad$ Quais terão que ser complementados?

\section{Conteúdo Programático}

$\S \quad$ Existe equilíbrio entre formas e funções?

$\S$ Quantas são adequadas à nossa situação real em sala de aula e aos interesses dos alunos?

\section{Metodologia}

$\S \quad$ As orientações metodológicas do livro do professor correspondem ao o material do livro do aluno para explorá-lo adequadamente?

$\S \quad$ São desenvolvidas estratégias cognitivas?

\section{Conteúdo linguístico}

$\S \quad$ Os temas de interesse são relevantes para os alunos?

$\S \quad$ Que processo de ensino é seguido?

$\S \quad$ A linguagem é apropriada?

$\S \quad$ Há léxico suficiente?

$\S \quad$ O léxico é apresentado em contexto?

$\S$ São considerados todos os aspectos fonéticos: discriminação de sons, sotaque, ritmo, entonação?

$\S \quad$ São tratados elementos de análise do discurso? Por exemplo, que o aluno responda perante situações imprevisíveis; que considere como são organizadas as frases entre si com fins comunicativos.

\section{Gradação da linguagem}

$\S \quad$ O aluno é exposto de forma suficiente a input compreensível?

$\S \quad$ É introduzido muito material novo de uma vez?

$\S \quad$ É pedido ao aluno que produza a maior parte do que recebe?

\section{Revisão}

$\S \quad$ Existe uma progressão linear ou cíclica?

$\S \quad$ Há unidades de revisão?

$\S \quad$ Estas unidades oferecem a possibilidade de selecionar o que nos interessa?

\section{Fases em uma unidade e habilidades}

$\S \quad$ As apresentações são feitas em um contexto interessante para os alunos?

$\S \quad$ Há atividades de prática variadas que podem ser selecionadas?

$\S \quad$ Há progressão da prática controlada à prática livre?

$\S \quad$ Há integração das habilidades?

$\S \quad$ Há possibilidade de o professor selecionar as partes que lhe interessam? 


\section{Material de apoio}

$\S$ No livro do professor são oferecidas ideias para explorar o material de forma variada?

$\S \quad$ O material visual tem finalidade pedagógica ou é um simples enfeite?

$\S$ Existe equilíbrio entre o material visual e o texto escrito de forma que um sirva de apoio para o outro?

$\S \quad$ As gravações são autênticas e úteis?

$\S \quad$ Existem apêndices que ajudem verdadeiramente na revisão ou na busca de material complementar?

$\S \quad$ O caderno de exercícios é realmente útil?

$\S \quad$ São incluídos materiais para a avaliação?

$\S$ Estes materiais correspondem com a ideia que temos de avaliação? Exemplo: provas de elementos particulares ou globais?

$\S \quad$ Existem folhas de autoavaliação para o aluno?

\section{Outros}

$\S \quad$ Um professor não nativo pode usar com facilidade este material?

$\S \quad$ O livro pertence a uma série didática e coincidem as mesmas características nos outros livros da série?

$\S$ Há em cada livro um índice com a programação dos outros livros da série?

$\S \quad$ O livro ou parte dele foi experimentado previamente em situações reais?

$\S \quad$ É de fácil manejo por seu aspecto, formato e tamanho?

$\S \quad$ Podem ser observadas linguagem e/ ou atitudes sexistas?

$\S \quad$ É fácil conseguir o livro no mercado?

Fonte: Ramiro (1996) 
Anexo 3 - "Propuesta de Ficha de análisis de manuales"

\begin{tabular}{|l|l|l|}
\hline \multicolumn{2}{|c|}{ DESCRIPCIÓN EXTERNA DEL MANUAL } \\
\hline Título & \\
\hline Autor/es & \\
\hline Datos bibliográficos & \multicolumn{2}{|c|}{} \\
\hline \multirow{4}{*}{ Material } & Impreso & \\
\cline { 2 - 3 } & Sonoro & \\
\cline { 2 - 3 } & Visual & \\
\cline { 2 - 3 } & Multimedia & \\
\hline
\end{tabular}

\begin{tabular}{|l|l|}
\hline \multicolumn{2}{|c|}{ DESCRIPCIÓN INTERNA DEL MANUAL } \\
\hline Objetivos generales & \\
\hline Metodología & \\
\hline Organización en niveles & \\
\hline Destinatario & \\
\hline Programación de objetivos y contenidos & \\
\hline Organización de cada lección & \\
\hline
\end{tabular}

Fonte: Fernandez López (2004) 
Anexo 3a - "Propuesta de Ficha de análisis de manuales"

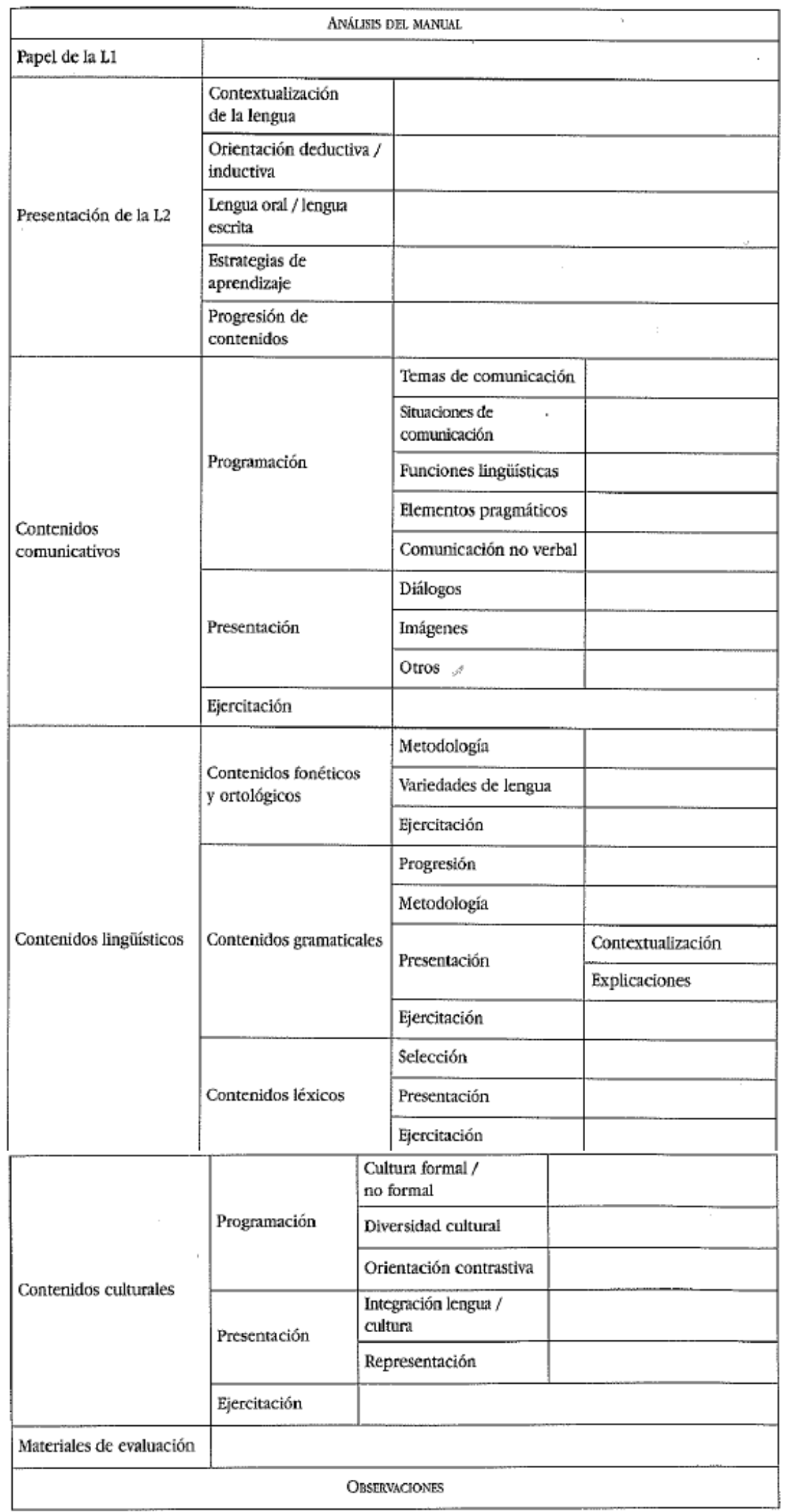

Fonte: Fernandez Lopez (2004) 
Anexo 3b - "Propuesta de Ficha de análisis de materiales"

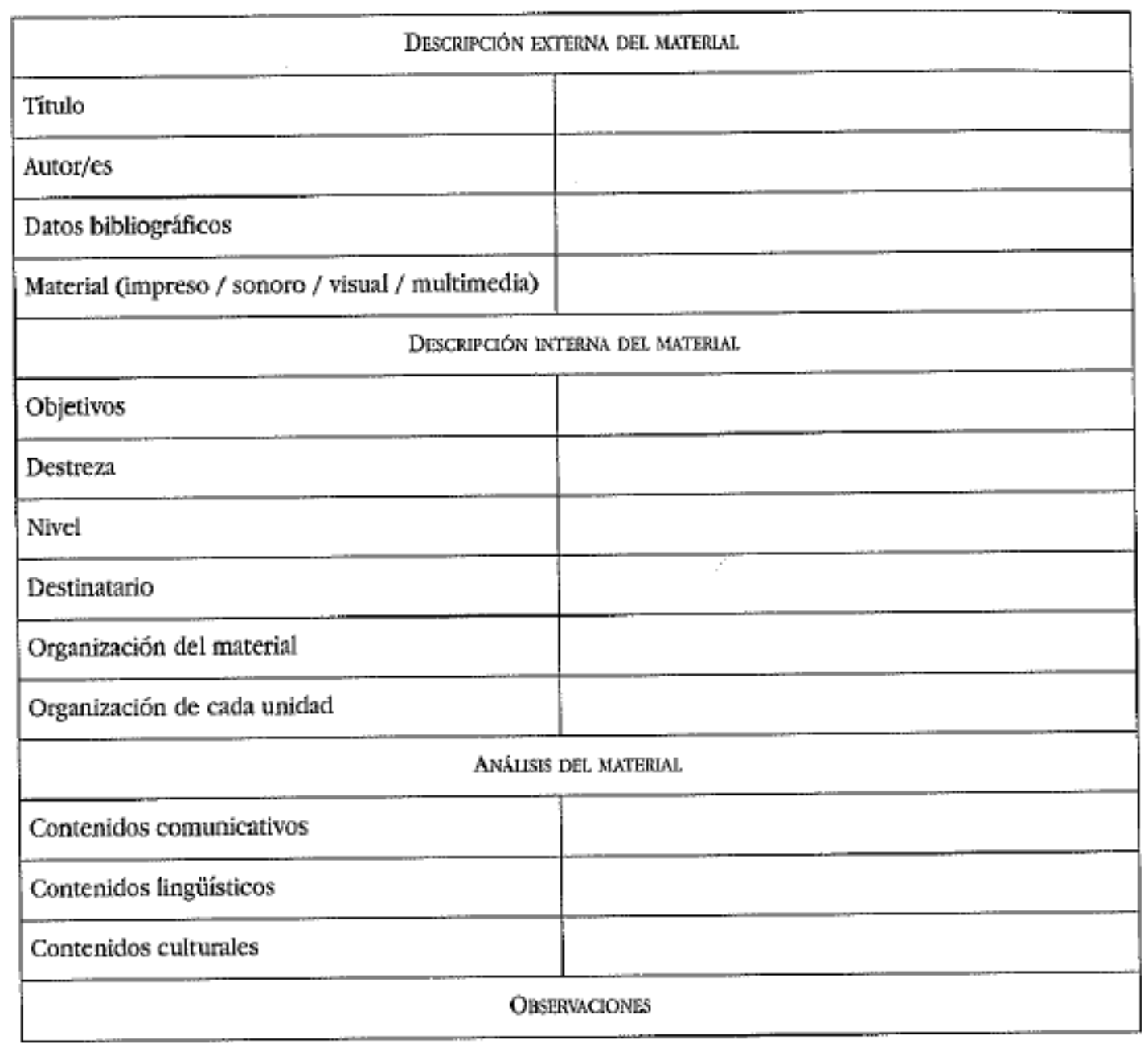

Fonte: Fernandez Lopez (2004) 


\section{Anexo 4a - LD da abordagem gramatical}

Figura 25 - Insumo com atividade de prática do código linguístico

PORTUGUÊS DINÂMICO

\section{LENDA}

Lenda é uma narrativa de cunho popular que é transmitida, principalmente de forma oral, de geração em geração. As lendas não podem ser comprovadas cientificamente pois são frutos da imaginação das pessoas que as criaram. O universo imaginário popular possui muitas lendas. Agora vamos falar do Saci Pererê que é o seu guia nesta jornada de aprendizagem.

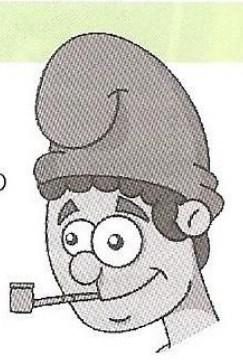

Esta lenda data do fim do século XVIII. Seu nome no Brasil tem origem no vocábulo "saci" do Tupi-Guarani. O Saci é uma criança, um negrinho de uma perna só, que fuma um cachimbo e usa na cabeça uma carapuça vermelha que lhe dá poderes mágicos, como o de desaparecer e aparecer onde quiser.

Ele adora fazer pequenas travessuras, como esconder brinquedos, soltar animais dos currais, derramar sal nas cozinhas, azedar o leite, fazer tranças nas crinas dos cavalos, esconder as tesourinhas de unha, queimar o feijão que está no fogo, etc. Como tem a mão furada deixa cair tudo o que pega. Os mais velhos assustavam as crianças com os relatos das travessuras do Saci. Diz a crença popular que dentro de todo redemoinho de vento existe um Saci.

Se alguém jogar dentro deste redemoinho um rosário de mato bento ou uma peneira, pode capturá-lo, e se conseguir sua carapuça, será recompensado com a realização de um desejo. Ele não atravessa córregos nem riachos. Alguém perseguido por ele, deve jogar cordas com nós em seu caminho para que ele pare para desatar os nós, deixando assim que a pessoa fuja. Em alguns lugares do Brasil ele é considerado, simplesmente, um menino brincalhão.

Mas cuidado! Ele pode estar em qualquer lugar!

\section{- Complete:}

1) O Saci é um negrinho de uma só que fuma um e usa na cabeça uma vermelha que the dá poderes mágicos.

2) Ele adora fazer pequenas travessuras, como esconder soltar animais dos , derramar sal nas , fazer tranças nas crinas dos etc.

3) Para capturá-lo é necessário jogar dentro do redemoinho um de mato bento ou uma

Fonte: Português Dinâmico (p. 40) 


\section{Anexo 4b - LD da abordagem gramatical}

Figura 26 - Atividades de prática do código linguístico

\section{O QUE É QUE FICOU NA MEMÓRIA?}

\section{1) Complete com contrações:}

Programas imperdíveis em São Paulo:

Conferir os Cantos Gregorianos

Visitar um __ grandes museus

__ Ipiranga; Curtir _ bila Olimpia; Visitar o Parque

Ipiranga; Curtir ___ bares
Vila Olímpia; Visitar o Parque Mosteiro de São Bento; ir a uma 1500 pizzarias como Masp e Museu Vila Madalena e ___ baladas Ibirapuera e suas atrações ou

2) Relacione as duas colunas:
(a) professor
( ) mesas, bandeja, gorjeta, restaurante, lanchonete
(b) médico
( ) leis, código, julgamento, processo, juiz
(c) advogado
( ) alunos, aula, livros, cadernos, provas
(d) arquiteto
( ) plantão, residência, roupa branca, doença
(e) garçom
( ) planos, casas, edifícios, maquete

\section{3) Escreva a estação correspondente:}
a) calor, sol, praia, ventilador
b) frio, neve, agasalhos, esquiar
c) árvores, folhas no chão, paisagem colorida
d) muitas flores, temperatura agradável

5) Escreva por extenso os seguintes números:
a) 218
b) 649
c) 1200
d) 5536

\section{4) Que horas são?}
a) $12 \mathrm{~h} 30$
b) $13 \mathrm{~h} 45$
c) $2 \mathrm{~h} 20$
d) $7 \mathrm{~h} 15$

Conte um ponto por cada acerto.

Menos de 9 - Mm... essa memória!

De 9 a 19 - Já está bastante bem! Parabéns!

De 20 a 30 - Excelente! Siga estudando.

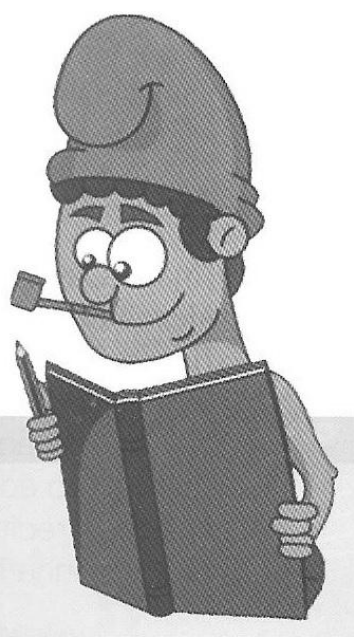

Fonte: Português Dinâmico (p. 41) 


\section{Anexo 5 - Transcrição da tipologia de tarefas de Barbirato (1999)}

\section{I- Tarefas de interação social}

a) Compartilhar e contar, Dubin \& Olshtain (1986) : nestes dois tipos de tarefas, os alunos terão que compartilhar experiências, e isso poderá ser realizado sob a forma de entrevistas, interações, pesquisas e opiniões. Os alunos poderão contribuir com experiências vividas por eles mesmos ou por outros, poderão contar histórias ou criá-las, reconstituir sequencias de histórias, pedir opiniões, discutir atitudes, manifestar preferências e reações pessoais. Eles poderão ainda lançar mão de narrativas e descrições.

Estas tarefas exigirão que o aprendiz esteja engajado em interações, com uma ênfase no social. Compartilhar experiências pessoais e contar é coisas que fazemos frequentemente em nossa rotina diária. Além disso, são tarefas que propiciam o uso da língua-alvo de uma maneira mais próxima daquilo que acontece fora da sala de aula.

b) Atividade de lacuna de opinião, Prabhu (1987): envolve a identificação e articulação de uma preferência pessoal, sentimento ou atitude em resposta a determinada situação. Um exemplo é completar uma história, outro é tomar parte numa discussão sobre uma questão social. A atividade pode envolver o uso de informação fatual e a formulação de argumentos para justificar uma opinião, mas não há procedimento objetivo para demonstrar resultados como certos ou errados e não há razão para esperar o mesmo resultado de diferentes indivíduos em diferentes ocasiões.

c) Desempenho de papéis Littlewood (1988): na tentativa de criar formas mais variadas de interação na sala de aula, segundo Littlewood (1988), professores de LE têm dado uma atenção especial para a área de simulação e, dentro desta área, especialmente para a atividade de desempenho de papéis. Com esta técnica pede-se aos alunos que

- se imaginem numa situação a qual possa ocorrer fora da sala de aula. Pode ser uma situação simples, como encontrar algum amigo na rua, ou um evento muito mais complexo, como uma série de discussões de negócios.

- adotem um papel específico na situação. Em alguns casos, eles podem agir como eles mesmos. Em outros, eles têm que adotar uma identidade simulada.

- se comportem como se a situação realmente existisse, de acordo com seus papéis.

O autor apresenta os seguintes tipos de desempenho de papéis:

- controlado por meio de pistas e informações.

- controlado por meio da situação e de objetivos.

- na forma de debates ou discussão.

De acordo com Stern (1992), o principal interesse desta técnica está no uso global da linguagem em situações da vida cotidiana. Em muitos casos, esta técnica se aproxima muito do uso da linguagem fora da sala de aula. Os cenários que podem ser imaginados ou simulados e as situações específicas nas quais podem ser descritas proporcionam um contexto e um estímulo para o uso "real" da língua. A vantagem da representação de papéis está no fato de que o desempenho comunicativo na situação dramática pode incluir o uso linguístico completo e complexo : tom emocional, postura, gesto e ações apropriadas. 


\section{II- Tarefas de Troca de Informação}

a) Atividade de lacuna de informação: envolve troca de informação de uma pessoa para outra, ou de uma forma para outra, ou de um lugar para outro, geralmente exigindo a decodificação de informação da ou na língua. Um exemplo é o trabalho em par, no qual cada membro do par tem uma parte da informação total (por exemplo, uma figura incompleta e tentar transmiti-la verbalmente para o outro). Outro exemplo é completar uma representação tabular com dados disponíveis numa parte do texto. A atividade frequentemente envolve seleção de informação relevante também, e os alunos podem ter que encontrar critérios para completar ou corrigir ao fazer a transferência (Prabhu, 1987).

Segundo Stern (1992), dentre os recentes conceitos para tomar o ensino comunicativo uma realidade, a lacuna de informação é talvez o conceito mais empregado.

Se A fala com B, A deve pressupor que B não sabe em adiantado o que A vai dizer, caso contrário não haveria razão em conversar. Acredita-se que a lacuna de informação seja um componente importante para as atividades de sala de aula e o fato de haver esta lacuna que deve ser preenchida faz com que o aluno dirija todo um esforço para o sucesso do preenchimento. Na verdade, em situações de uso da língua fora da sala de aula, um dos objetivos da comunicação é geralmente transmitir ou obter informações e, ao se usar atividades na aula de línguas que possuem este objetivo, pode-se ajudar o aluno a perceber melhor o propósito de se aprender uma nova língua.

\section{III- Tarefas cognitivas:}

a) Atividade de lacuna de raciocínio: envolve derivar alguma informação por meio de processos de inferência, dedução, raciocínio prático ou uma percepção das relações ou estruturas. Um exemplo é planejar o horário de um professor nas bases do horário das aulas dado. Outro é decidir qual curso de ação é melhor (por exemplo, mais barato ou mais rápido) para um determinado objetivo e dentro de restrições específicas. A atividade envolve compreensão e transmissão de informações, mas as informações a serem transmitidas não são idênticas àquelas inicialmente compreendidas. Há uma parte de raciocínio que conecta as duas, Prabhu (1987).

b Resolução de problemas : envolvem os aprendizes na tomada de decisões sobre um ponto em questão enquanto usam a língua-alvo, capacitando-os a se concentrarem mais nas características da atividade do que nos aspectos formais. De acordo com Stern (1992), algumas atividades são designadas para apresentar aos alunos problemas ou quebra cabeças que chamem sua curiosidade. Para encontrar a solução, pares, pequenos grupos ou a classe como um todo devem pensar e falar sobre o problema. Este tipo de tarefa envolve o uso da língua-alvo com um foco no problema em vez da língua, e isto é precisamente o motivo pelo qual professores acham este tipo de atividade útil.

Um exemplo que pode ser citado seria o seguinte: pequenos grupos discutem um tópico político ou de interesse local, na tentativa de alcançar consenso com respeito a um problema ou questão, fazendo recomendações e tentando estabelecer uma política (um código) de procedimentos padronizados para uma dada situação (Fontão do Patrocínio, 1997).

c) Operações I transformações: capacitam os alunos a focalizar características semânticogramaticais que são necessárias quando ajudam na acuidade do uso da língua. De acordo com Dubin\&Olhstain, todos os alunos requerem tarefas previsíveis e controláveis quando têm como objetivo adquirir acuidade na produção e interpretação da linguagem. Exemplos: elementos da língua são apagados, substituídos, reordenados ou combinados; opções para elementos linguísticos são apresentadas de forma que os aprendizes possam escolher uma delas (Fontão do Patrocínio, 1997:73).

Fonte: Barbirato 1999, p. 72, 73, 74, 75 


\section{Anexo 6 - Exemplos de Atividades de Prática do Código Linguístico}

Figura 27 - Preenchimento de lacunas

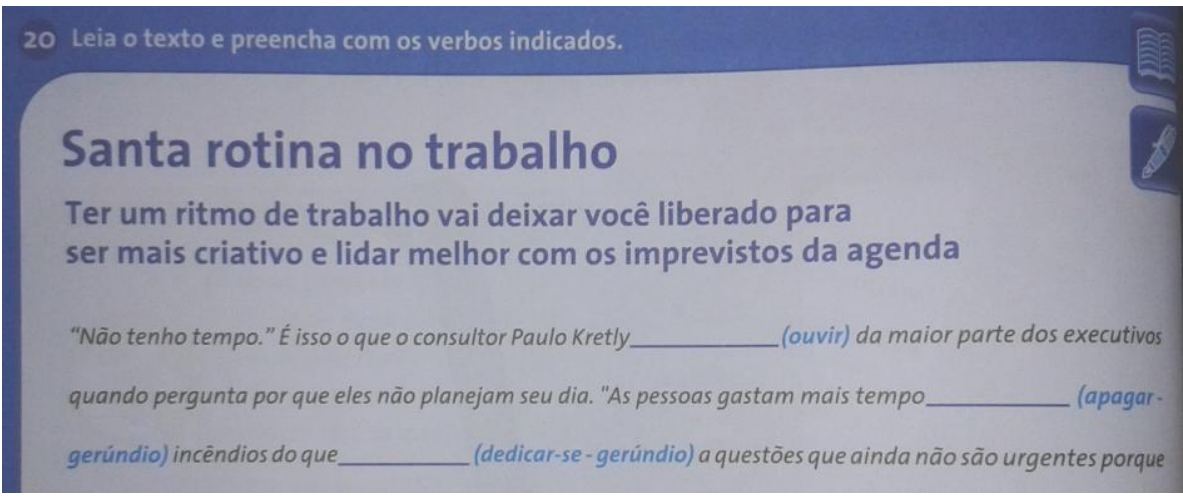

Figura 28 - Produção direcionada ao uso de determinados conteúdos
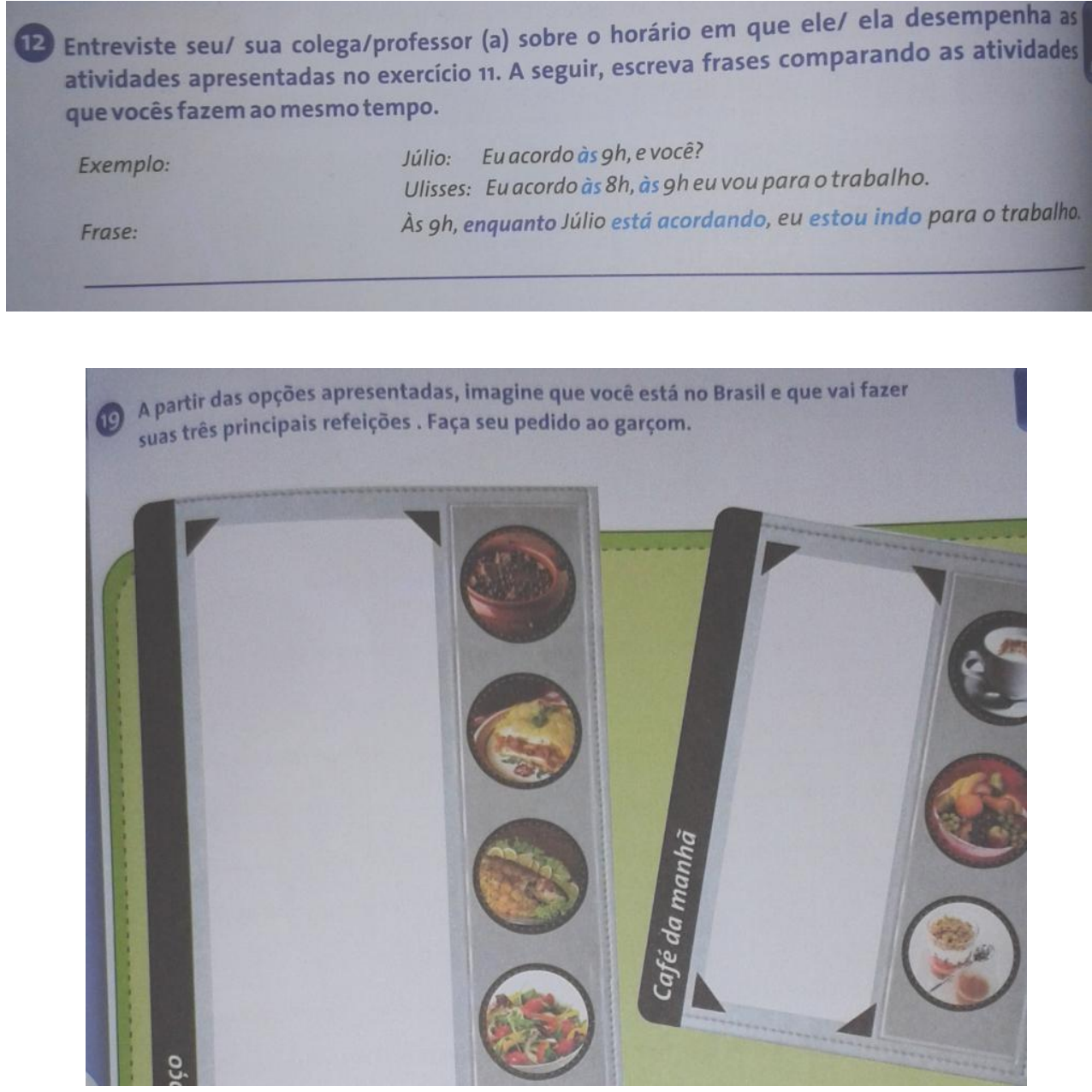

Fonte: Brasil Intercultural - Ciclo Básico (págs. 38 e 47) 


\section{Anexo 6a - Exemplos de Atividades de Prática do Código Linguístico}

\section{Figura 29 - Relacionar Colunas/fotos}

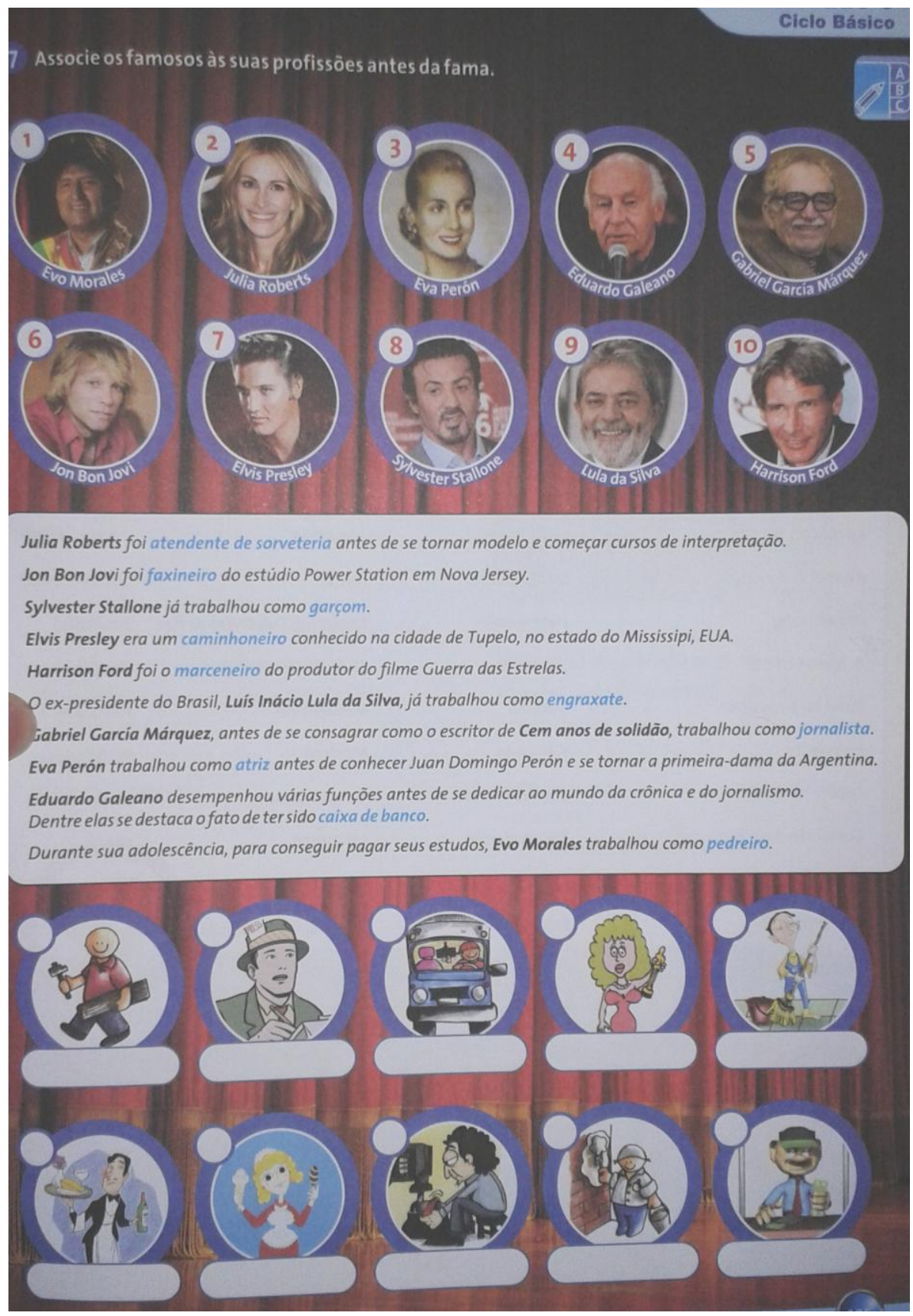

Fonte: Brasil Intercultural - Ciclo Básico (págs. 54 e 105) 


\section{Anexo 6b - Exemplos de Atividades de Prática do Código Linguístico}

\section{Figura 30 - Substituição}

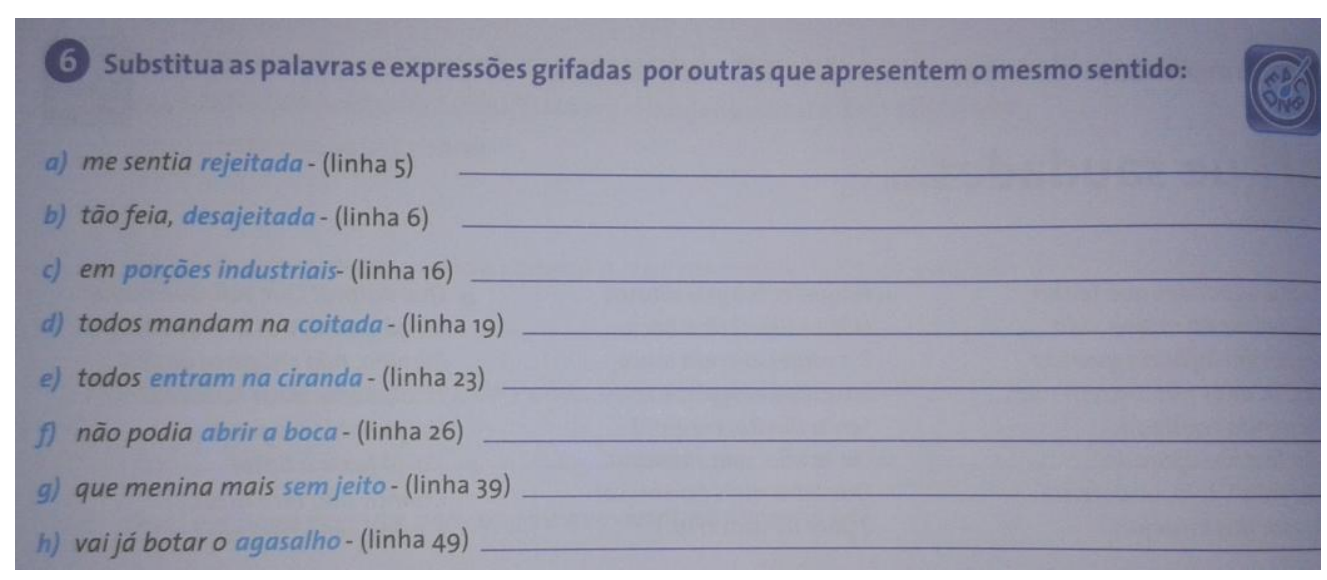

Fonte: Brasil Intercultural - Ciclo Básico (p.74.6)

Figura 31 - Seleção de informação

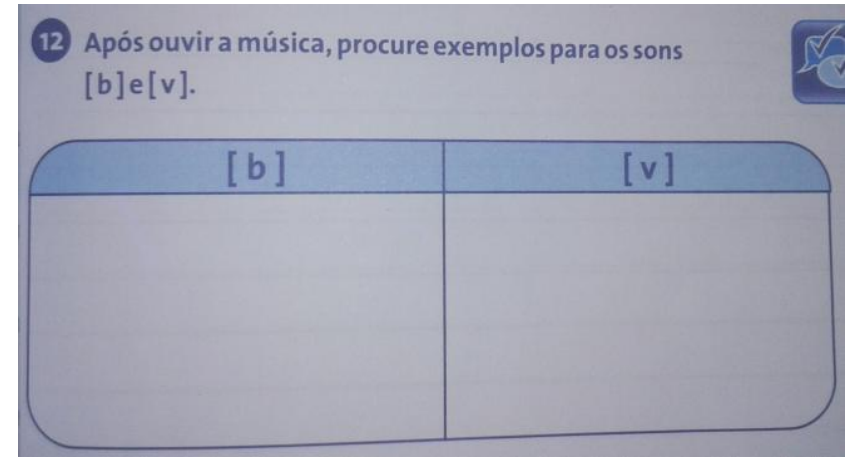

Fonte: Brasil Intercultural - Ciclo Básico (p.79)

\section{Figura 32 - Classificação de informação}

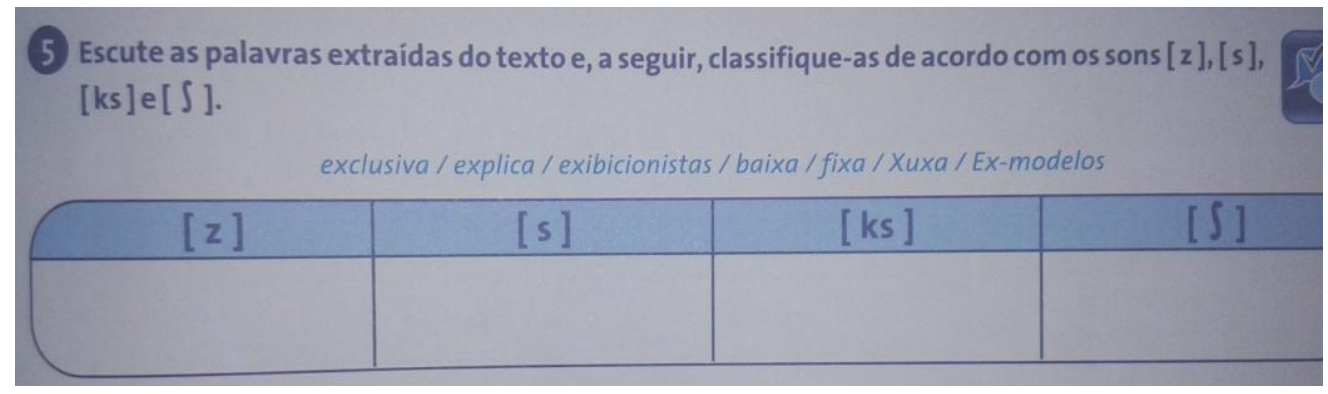

Fonte: Brasil Intercultural - Ciclo Básico (p.103) 


\section{Anexo 6c - Exemplos de Atividades de Prática do Código Linguístico}

\section{Figura 33 - Verdadeiro ou Falso}

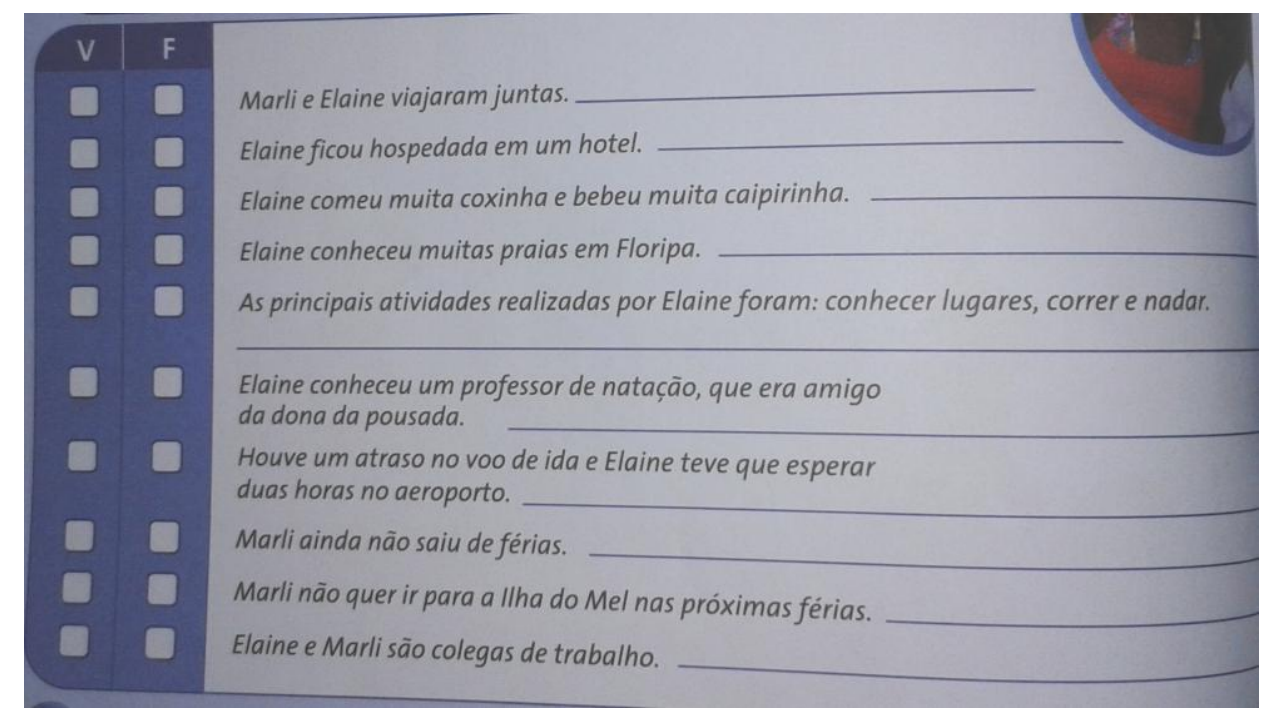

Fonte: Brasil Intercultural - Ciclo Básico (p. 58) 


\title{
Anexo 7 - Exemplos de Insumo do LD "Brasil Intercultural - Ciclo Básico"
}

\author{
Figura 34 - Texto jornalístico
}

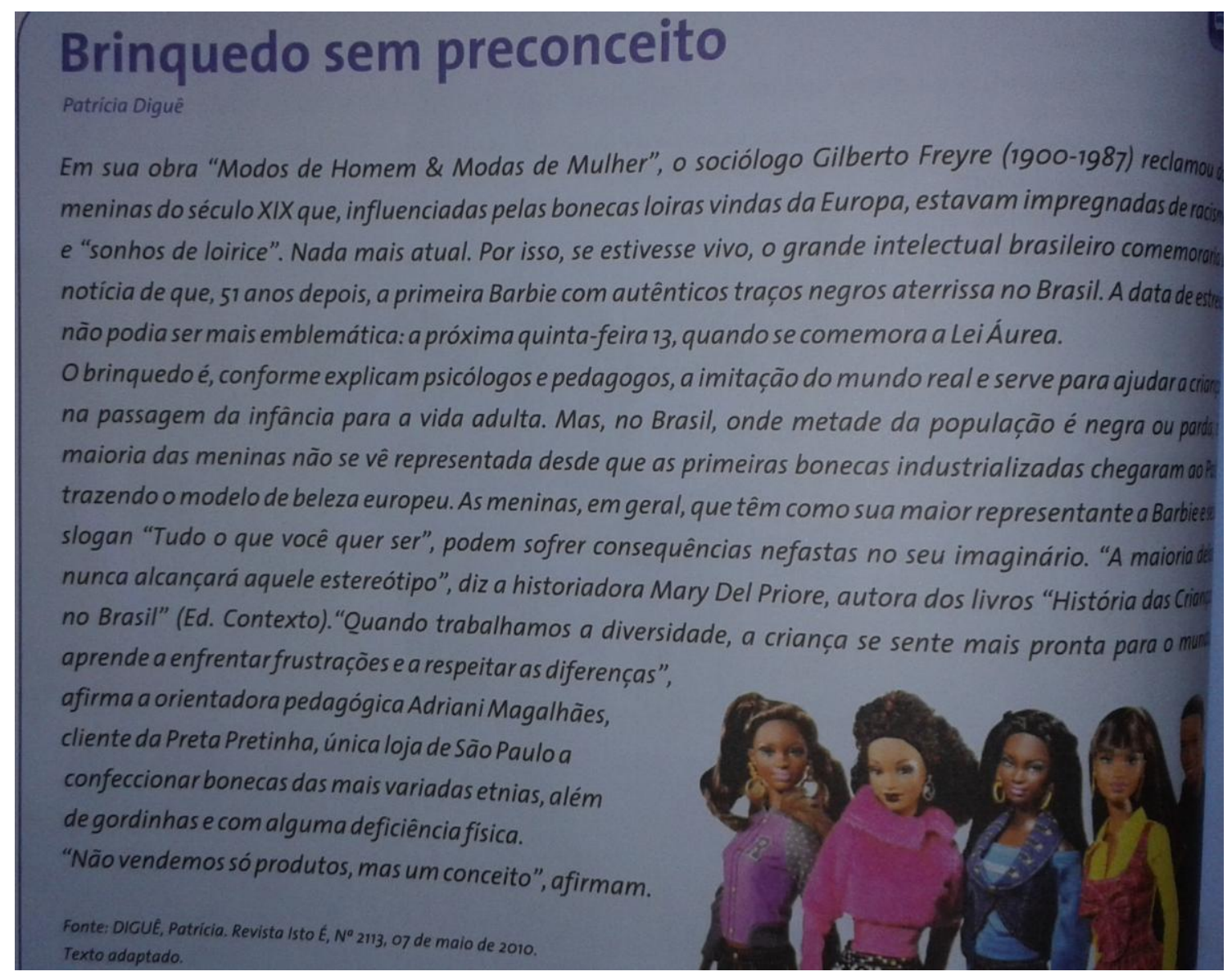

Fonte: Brasil Intercultural - Ciclo Básico (p. 74) 


\section{Anexo 8 - Formação de aprendizes}

\section{Figura 35 - Motivos para estudar português e estratégias de leitura}

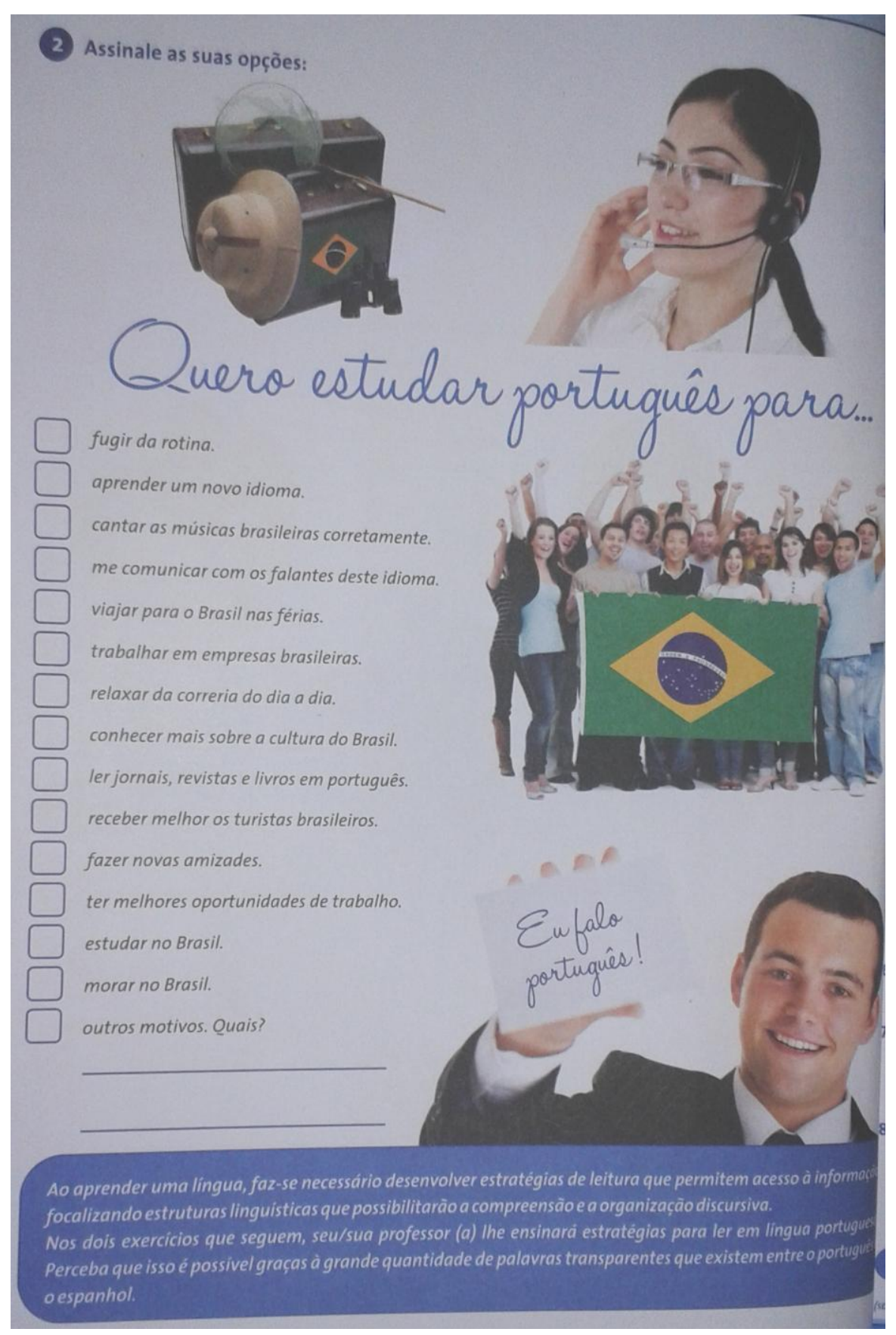

Fonte: Brasil Intercultural - Ciclo Básico (p. 6) 


\section{Anexo 8b - A abordagem gramatical em Brasil Intercultural}

\section{Figura 36 - Lista de vocabulário}

\begin{tabular}{|c|c|c|c|}
\hline \multicolumn{4}{|c|}{ Países e nacionalidades } \\
\hline \multicolumn{4}{|c|}{$\begin{array}{l}\text { Os vinhos franceses säo motivo de orgulho nacional. } \\
\text { A culinária tradicional japonesa é dominada pelo arroz branco e poucas refeiçôes seriam completas sem ele. }\end{array}$} \\
\hline \multirow{2}{*}{\multicolumn{2}{|c|}{ PAis }} & \multicolumn{2}{|c|}{ NACIONALIDADE } \\
\hline & & MASCULINO & FEMININO \\
\hline$=$ & Alemanha & alemão & alemã \\
\hline$\%$ & Argentina & argentino & argentina \\
\hline \% & Austrália & australiano & australiana \\
\hline 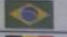 & Brasil & brasileiro & brasileira \\
\hline 11 & Bélgica & belga & belga \\
\hline 플 & Bolivia & boliviano & boliviana \\
\hline $1+1$ & Canadá & canadense & canadense \\
\hline 2 & Chile & chileno & chilena \\
\hline$E$ & China & chinês & chinesa \\
\hline 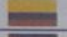 & Colômbia & colombiano & colombiana \\
\hline$\equiv$ & Cuba & cubano & cubana \\
\hline-5 & Equador & equatoriano & equatoriana \\
\hline 2 & Espanha & espanhol & espanhola \\
\hline
\end{tabular}

Fonte: Brasil Intercultural - Ciclo Básico (p. 42)

\section{Figura 37 - Gramática: conjugação do presente do indicativo}

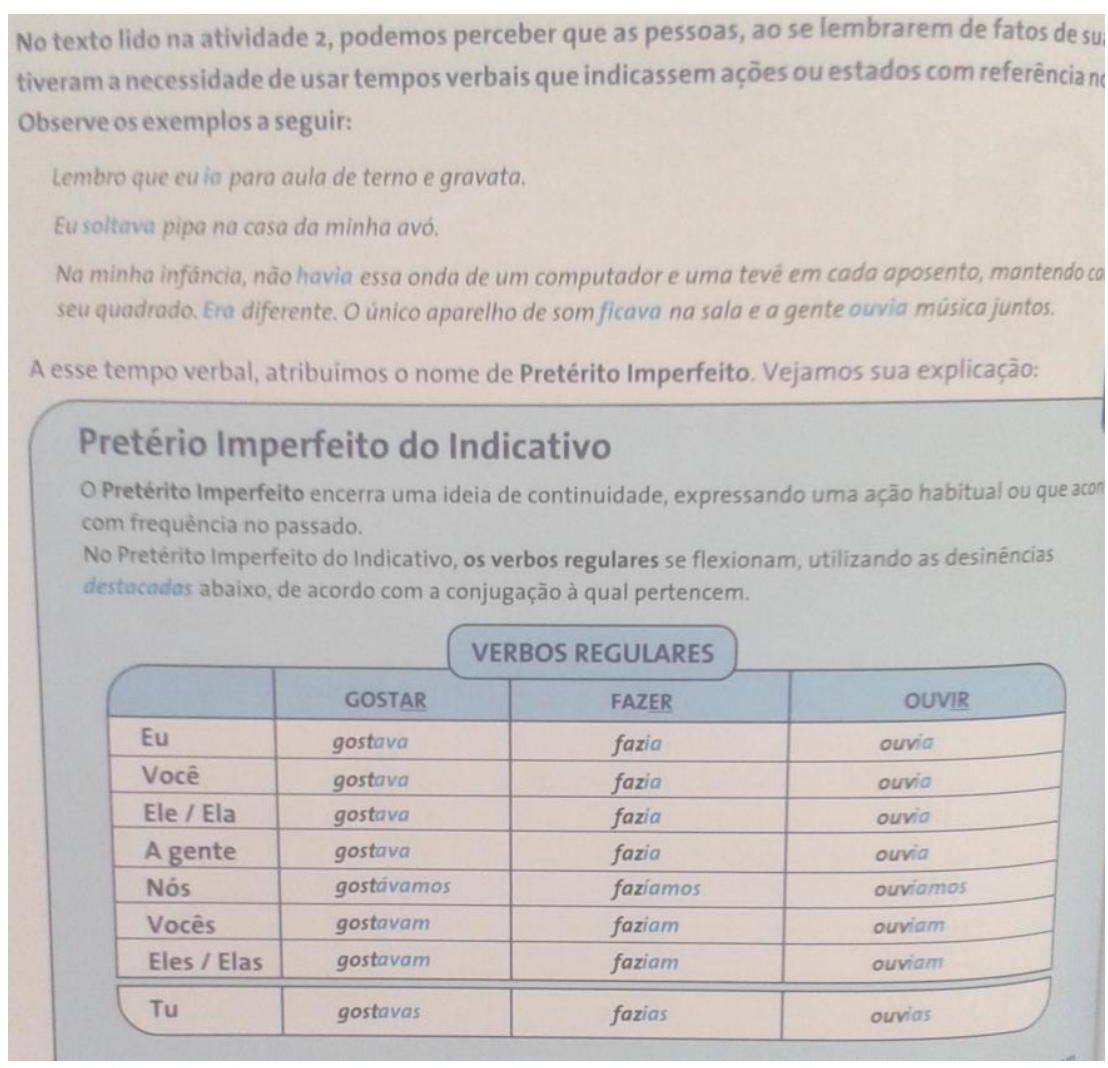

Fonte: Brasil Intercultural (p. 55) 


\section{Anexo 9 - Exemplos de Atividades Comunicativas "Leituras extensivas" e informação complementar}

\section{Figura 38 - Leitura Complementar}

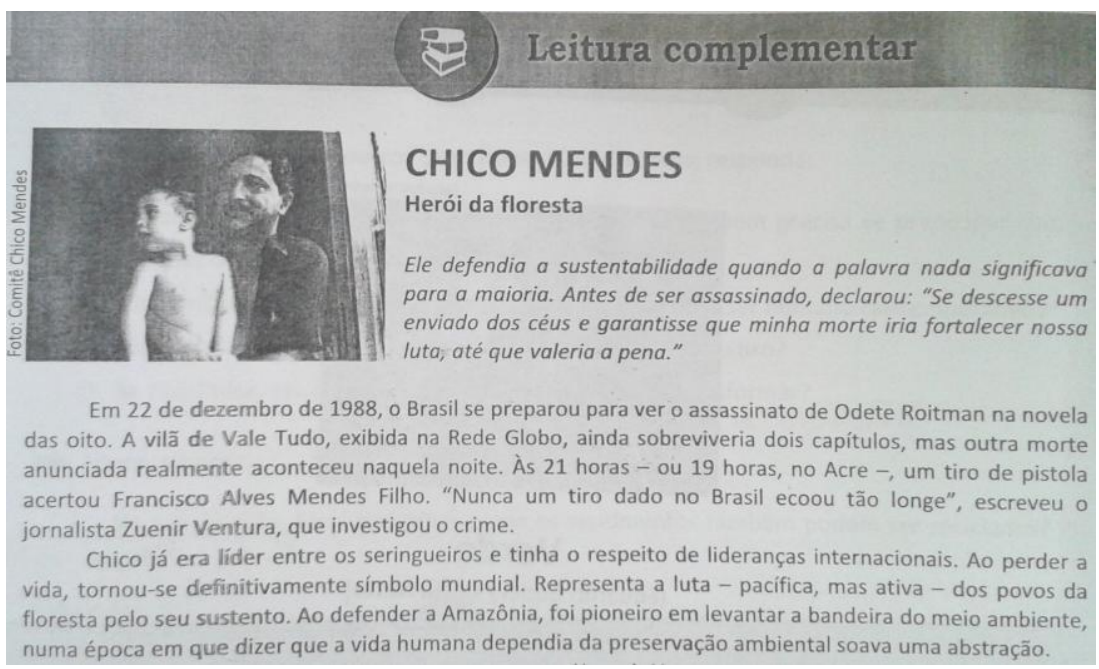

Fonte: Horizontes: Rumo à proficiência em Língua Portuguesa (p. 48)

Figura 39 - Sugestões de leituras, filmes, documentários, sites

\section{Sugestões}

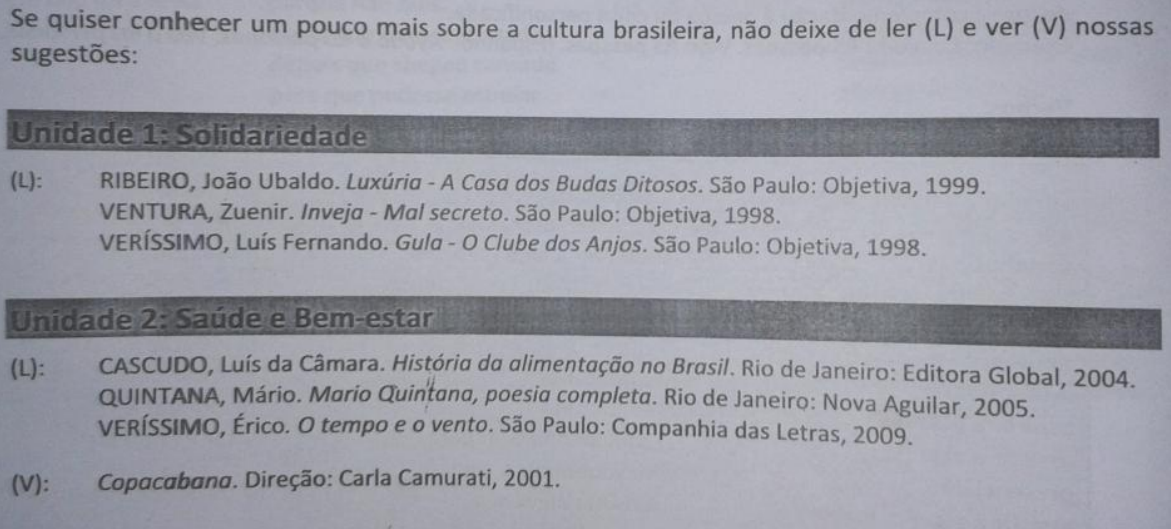

Fonte: Horizontes: Rumo à proficiência em Língua Portuguesa (p. 132) 


\section{Anexo 10 - Exemplo de Informação complementar}

Figura 40 - Informação complementar

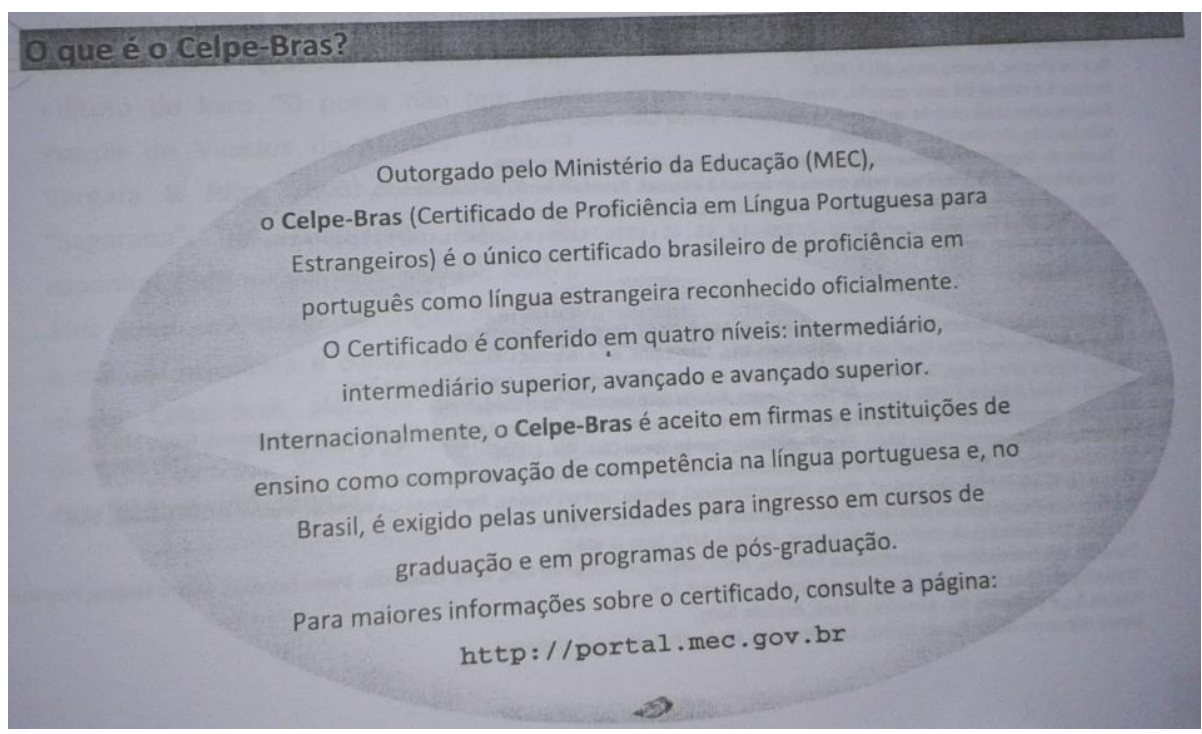

Fonte: Horizontes: Rumo à proficiência em Língua Portuguesa (p. 132) 


\section{Anexo 11 - FICHA DE AVALIAÇÃo GUIA DO PNLD - Ensino Médio (2012)}

\section{CRITÉRIOS TEÓRICO-METODOLÓGICOS GERAIS E RELATIVOS A LÍNGUA ESTRANGEIRA MODERNA}

\section{BLOCO I - COM RELAÇÃO AO PROJETO GRÁFICO-EDITORIAL, A COLEÇÃO:}

1. Demonstra uma organização clara, coerente e funcional, adequada à proposta didático-pedagógica?

2. Apresenta legibilidade gráfica adequada, do ponto de vista do/a/s: desenhos; tamanho das letras; espaçamento entre letras, palavras e linhas; formato, dimensão e disposição dos textos na página; impressão do texto principal em preto; recursos gráficos que hierarquizam títulos e subtítulos e identificam o tipo de atividade proposta?

3. É isenta de erros de revisão e/ou de impressão?

4. Dispõe de: glossários, referências bibliográficas, índice remissivo, indicação de leituras complementares, indicação das faixas do $\mathrm{CD}$, sumário que identifique princípio(s) organizador(es), sumário que garanta a rápida localização das informações?

5. Apresenta impressão feita de modo a não prejudicar a legibilidade no verso da página?

6. Possui ilustrações que apresentam: créditos; clara identificação dos locais de custódia; gráficos e tabelas com títulos, fontes e datas; respeito, quando de caráter científico, às proporções entre objetos ou seres representados; legendas, escala, coordenadas e orientação em conformidade com as convenções cartográficas, no caso de mapas e outras representações gráficas do espaço; adequação às finalidades para as quais foram utilizadas; clareza e precisão; exposição da diversidade étnica e cultural da população brasileira; exposição da diversidade étnica e cultural das comunidades das regiões e dos países em que a língua estrangeira é falada; exposição da pluralidade do mundo social?

\section{BLOCO II - COM RELAÇÃO AOS TEXTOS, A COLEÇÃO:}

7. Reúne um conjunto representativo de diferentes comunidades falantes da língua estrangeira?

8. Aborda temas adequados ao ensino médio?

9. Contempla diversidade de: tipos textuais; gêneros, textos verbais e não verbais? 
10. Inclui textos que circularam no mundo social, oriundos de diferentes esferas e suportes? Em caso positivo, marque as esferas incluídas: científica, cotidiana, jornalística, jurídica, literária, publicitária, outra(s) esfera(s) - especifique. Em caso positivo, marque os suportes incluídos: impresso, digital, virtual, outro(s) suporte(s) Especifique.

11. Apresenta de modo correto, preciso e atualizado, conceitos, informações e procedimentos?

\section{BLOCO III - NO QUE SE REFERE À COMPREENSÃO LEITORA, A COLEÇÃO:}

12. Propõe atividades de: Pré-leitura? Leitura, que contemple uma efetiva interação texto-leitor? Pós-leitura?

13. Trabalha estratégias, tais como localização de informações explícitas e implícitas no texto, levantamento de hipóteses, produção de inferência, compreensão detalhada e global do texto, dentre outras? Em caso positivo, especifique quais.

14. Propõe atividades que estimulem a leitura crítica?

\section{BLOCO IV - NO QUE SE REFERE À PRODUÇÃO ESCRITA, A COLEÇÃO:}

15. Propõe atividades que pressupõem um processo de interação, de modo a considerar: quem, para quem, com que objetivo e em que suporte se escreve?

16. Relaciona a produção de textos escritos a diversos contextos e gêneros textuais?

17. Contém atividades que promovem um constante processo de reelaboração do texto?

\section{BLOCO V - NO QUE SE REFERE À COMPREENSÃO ORAL, A COLEÇÃO:}

18. Apresenta CD em áudio com boa qualidade sonora?

19. Apresenta CD em áudio com gravações compatíveis com a situação comunicativa abordada?

20. Propõe atividades de compreensão: Intensiva (reconhecimento e reprodução de sons, palavras, sentenças)? Extensiva (exposição da ideia geral do texto oral)? Seletiva (identificação de informação pontual)?

21. Promove atividades, com materiais gravados em $\mathrm{CD}$ em áudio, baseadas em gêneros e propósitos variados? 
22. Permite o acesso a variedades linguísticas, por meio de diferentes pronúncias e prosódias?

\section{BLOCO VI - NO QUE SE REFERE À EXPRESSÃO ORAL, A COLEÇÃO:}

23. Propõe práticas que possibilitam aos jovens estudantes interagir significativamente na língua estrangeira?

24. Contém atividades relativas a diferentes situações comunicativas, que permitem o uso de diversos registros?

\section{BLOCO VII: NO QUE SE REFERE AOS ELEMENTOS LINGUÍSTICOS, A COLEÇÃO:}

25. Propõe a sistematização de conhecimentos linguísticos, a partir de práticas discursivas variadas?

26. Aborda variações linguísticas da língua estrangeira?

27. É isenta de informações metalinguísticas equivocadas ou simplificações que possam conduzir ao erro?

28. É isenta de erros e inadequações no uso da língua estrangeira?

\section{BLOCO VIII - COM RELAÇÃO ÀS ATIVIDADES, A COLEÇÃO:}

29. Integra a produção e a compreensão escrita e oral?

30. Oferece uma progressão na complexidade das tarefas?

31. Apresenta um equilíbrio na distribuição das tarefas das quatro habilidades?

32. Oferece oportunidades para que o estudante atue com autonomia nas quatro habilidades?

33. Apresenta variedade de atividades que favoreça o desenvolvimento das habilidades propostas?

34. Utiliza de modo correto, preciso e atualizado conceitos e informações, tanto linguísticas como de outra natureza?

35. Explora relações de intertextualidade?

36. Propicia experiências estéticas por meio de textos verbais e não verbais?

37. Contextualiza os textos artísticos verbais e não verbais em relação ao momento histórico e à corrente a que pertencem? 
38. Cria inter-relações com o entorno da escola, estimulando a participação social dos jovens, em sua comunidade, como agentes de transformações?

\section{BLOCO IX - NO QUE SE REFERE A QUESTÕES TEÓRICO- METODOLÓGICAS, A COLEÇÃO:}

39. Apresenta coerência entre sua fundamentação teórico-metodológica e o conjunto de textos, atividades, exercícios etc.?

40. Organiza-se de forma a garantir a progressão do processo de ensino aprendizagem?

41. Propõe atividades de avaliação e de autoavaliação que integram os diferentes aspectos que compõem os estudos da linguagem nesse nível de ensino, buscando harmonizar conhecimentos linguístico-discursivos e aspectos culturais relacionados à expressão e à compreensão na língua estrangeira?

42. Contribui para a apreensão das relações que se estabelecem entre a língua estrangeira e as suas funções socioculturais?

43. Favorece o desenvolvimento de capacidades básicas do pensamento autônomo e crítico?

\section{BLOCO $X$ - NO QUE SE REFERE AO MANUAL DO PROFESSOR, A COLEÇÃO:}

44. Descreve a organização geral da coleção no conjunto dos volumes?

45. Descreve a organização geral interna de cada volume?

46. Explicita os objetivos da proposta didático-pedagógica efetivada?

47. Expõe os pressupostos teórico-metodológicos por ela assumidos?

48. Expõe estratégias e recursos de ensino necessários para o uso dos volumes?

49. Sugere respostas às atividades propostas no Livro do Aluno, sem que tenham caráter exclusivo nem restritivo, em especial quando se referem a questões relacionadas à diversidade linguística e cultural expressa na língua estrangeira?

50. Relaciona a proposta didático-pedagógica aos principais documentos públicos nacionais que orientam o ensino médio?

51. Indica possibilidades de trabalho interdisciplinar na escola, a partir do componente curricular abordado no Livro do Aluno? 
52. Discute diferentes formas, possibilidades, recursos e instrumentos de avaliação que o professor poderá utilizar?

53. Propicia ao professor a reflexão sobre sua prática docente, favorecendo a interação com os demais profissionais da escola?

54. Inclui informações que favorecem a atividade do professor, proporcionando-lhe condições de expandir seus conhecimentos acerca da língua estrangeira e de traços culturais vinculados a comunidades que se expressam por meio dessa língua?

55. Sugere leituras de aprofundamento?

56. Apresenta atividades complementares às do Livro do Aluno para o desenvolvimento tanto da compreensão como da produção em língua estrangeira, mantendo-se os critérios de diversidade de gêneros, suportes, e contextos de circulação?

57. Oferece referências suplementares (sítios de internet, livros, revistas, filmes, outros materiais) que apoiem atividades propostas no livro do aluno?

58. Apresenta coerência entre o proposto no Manual do Professor e o Livro do Aluno?

\section{BLOCO XI - NO QUE SE REFERE AO SEU CONJUNTO:}

59. Aponte as principais carências da coleção.

\section{QUANTO AOS CRITÉRIOS COMUNS A TODAS AS ÁREAS, A COLEÇÃO:}

60. Atende à legislação, às diretrizes e às normas oficiais relativas ao ensino médio?

61. É isenta de estereótipos e preconceitos: social, regional; étnico-racial; cultural; de gênero; de orientação sexual; de idade; outras formas de discriminação ou de violação de direitos?

62. É isenta de doutrinação religiosa ou política, respeitando o caráter laico e autônomo do ensino público?

63. É isenta de publicidade ou de difusão de marcas, produtos ou serviços comerciais?

Fonte : disponível em http://www.fnde.gov.br/arquivos/category/125-

guias?download=5510:pnld-2012-lingua-estrangeira 